\title{
Writiong and
}

Renutnciathion in

Medieval Japan

The Works of

the Poet-Priest

Kamo no Chōmei
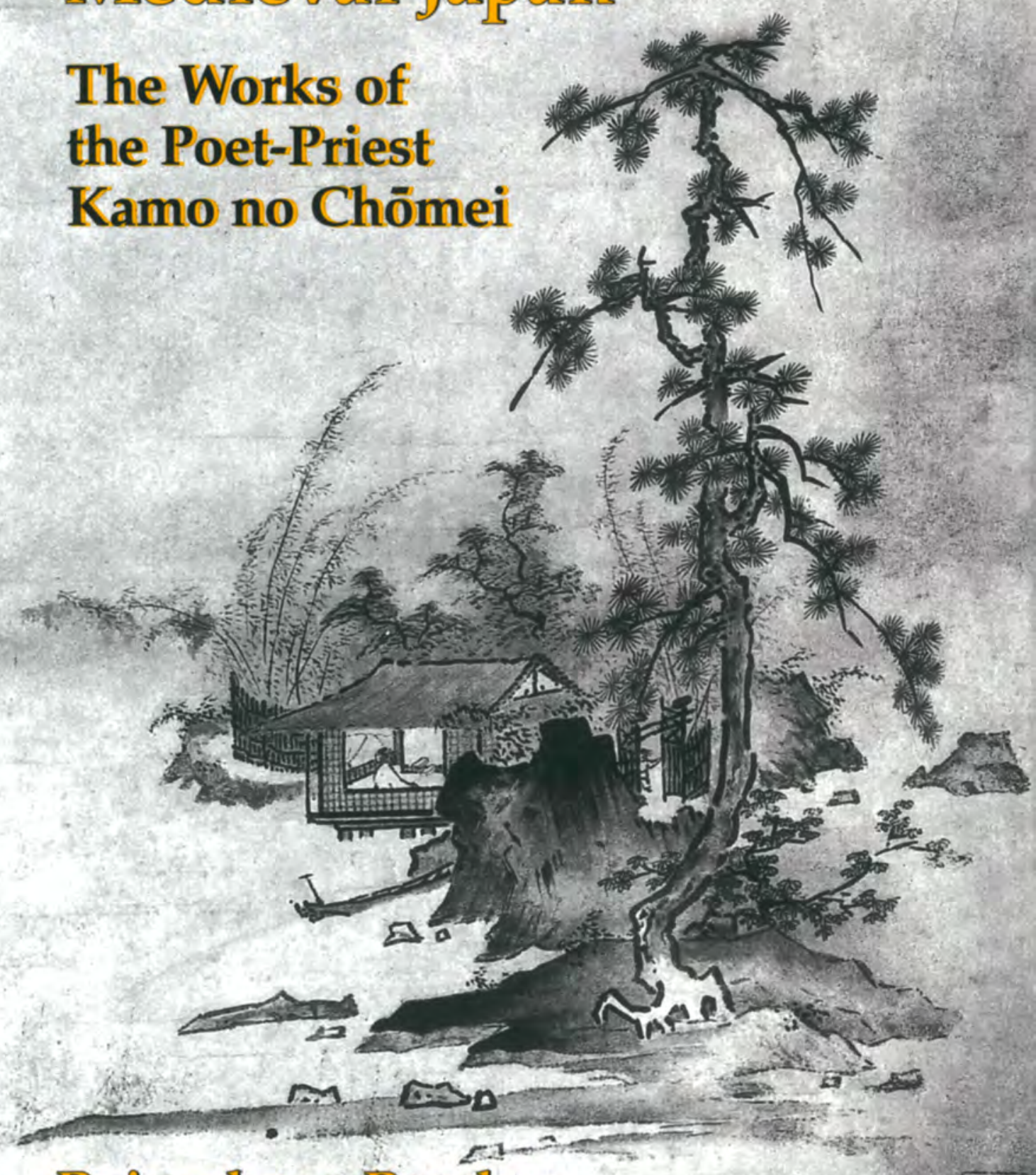

Rajyashuree Pandley 


\section{Writing and Renunciation in Medieval Japan}


Michigan Monograph Series in Japanese Studies Number 21

Center for Japanese Studies The University of Michigan 


\title{
Writing and Renunciation in Medieval Japan
}

The Works of the Poet-Priest Kamo no Chōmei

\author{
Rajyashree Pandey
}

Center for Japanese Studies

The University of Michigan

Ann Arbor, 1998 
Open access edition funded by the National Endowment for the Humanities/ Andrew W. Mellon Foundation Humanities Open Book Program.

(C) 1998 The Regents of the University of Michigan

Published by the Center for Japanese Studies, The University of Michigan, 202 S. Thayer St., Ann Arbor, MI 48104-1608

Distributed by The University of Michigan Press, 839 Greene St. / P.O. Box 1 104, Ann Arbor, MI 48106-1 104

\section{Library of Congress Cataloging in Publication Data}

Pandey, Rajyashree, 1953-

Writing and renunciation in medieval Japan : the works of the poetpriest Kamo no Chōmei / Rajyashree Pandey.

21)

199 p. 23 cm. - (Michigan monograph series in Japanese studies :

Includes bibliographical references and index.

ISBN 0-939512-86-6 (alk. paper)

1. Kamo, Chōmei, 1153?-1216?-Criticism and interpretation.

I. Title. II. Series.

PL791.2.Z5P36 1998

$895.6^{\prime} 422-\mathrm{dc} 21$

Jacket illustration: Bunsei, Landscape (detail), Japanese, mid-15th century, Muromachi period. Hanging scroll, ink and light colors on paper (05.203). Chinese and Japanese Special Fund. Courtesy of the Museum of Fine Arts, Boston.

Jacket design: Seiko Semones

This publication meets the ANSI/NISO Standards for Permanence of Paper for Publications and Documents in Libraries and Archives (Z39.48-1992).

Published in the United States of America

ISBN 978-0-939512-86-7 (hardcover)

ISBN 978-0-472-03828-2 (paper)

ISBN 978-0-472-12793-1 (ebook)

ISBN 978-0-472-90189-0 (open access)

The text of this book is licensed under a Creative Commons Attribution-NonCommercial-NoDerivatives 4.0 International License: https://creativecommons.org/licenses/by-nc-nd/4.0/ 
To the memory of $\mathrm{Ai}$ 



\section{Contents}

Preface ix

Introduction 1

Chapter One $\quad 9$

"Wild Words and Fancy Phrases": Debates on the Role

of Literature in the Heian and Kamakura Periods

Chapter Two

Kamo no Chōmei: Court Poet and Buddhist Priest.

Chapter Three

The Way of Poetry: Mumyōshō

Chapter Four

Suki and the Attainment of Religious Awakening:

Hosshinshū

Chapter Five

The Sukimono as Recluse: Hōjōki

Appendix One

The Kamo no Chōmei Incident (An Excerpt from

Minamoto Ienaga nikkil

Appendix Two

Selected Translations from Hosshinshū

Bibliography

Index 



\section{Preface}

My first encounter with classical Japanese literature came through a chance reading of Arthur Waley's translation of Genji monogatari. A student of English and French literature in India, I had hitherto had little contact with other Asian cultures-my formal education bore all the marks of its colonial origins. Waley's Genji offered me a first and beguiling glimpse of a world that shared something of the Indian religious sensibility but expressed itself in an aesthetic mode quite alien to that found in Indian literary writing. It was with a desire to pursue this newfound "Japan," from the perspective of an Indian steeped in the Western tradition, that I embarked upon my study of Japanese language and literature. Friedhelm Hardy offered enthusiastic support in the early days of this new venture.

My interest in classical Japanese literature was sustained and encouraged by a number of fine teachers. Dr. James McMullen at Oxford University inspired me with his academic rigor and his knowledge of classical Japanese literature. Subsequently, Professors Robert Morrell and Thomas Rimer, then at Washington University in St. Louis, guided me through a study of a variety of classical Japanese texts. Working with them paved the way for my engagement with popular medieval narratives, particularly those inflected with strong Buddhist overtones.

The idea for this book first germinated when I completed my doctoral dissertation on the works of Kamo no Chōmei at the Australian National University in 1989. My decision to focus on Kamo no Chōmei was guided by the fact that, although he was a major literary and intellectual figure of the medieval period, he had received surprisingly little systematic attention outside of Japan. I wish to express my deepest gratitude to my dissertation advisor and friend, 
Dr. Tom Harper, who simultaneously advised, listened, and offered help, while at the same time encouraged me to find my own path. He pointed me to a wide range of medieval literary texts that had been little explored outside of Japan.

In the course of this research, I was struck by the persistence with which the question of the value and legitimacy of writing was debated in medieval Japanese writing, and by the way in which the question of writing came to be formulated and addressed from within a Buddhist epistemic framework. I found that Kamo no Chōmei's works acquired greater significance and richness once they were read in conjunction with other medieval texts, many of which were bound by a common thread: the imperative to work out the relationship between writing, a profoundly worldly activity, and renunciation, which was central to the attainment of Buddhist enlightenment.

During a number of research trips to Japan, I had the good fortune to work with Professor Yamada Shozen at Taisho University and Professors Mizuhara Hajime and Yasuaki Nara at Komazawa University. I cannot thank them enough for the generosity with which they gave of their time and their knowledge. Dr. Michael Cooper provided much encouragement and support during my stays in Tokyo. I also owe a deep debt of gratitude to Mrs. Sonoe Matsui and her family, who adopted me into their home and looked after me as one of their own.

There are many friends who have contributed to the making of this book: my thanks to Dipesh Chakrabarty, Frieda Freiberg, Leela Gandhi, Aruna Hardy, Iso Mizue, Pauline Nestor, Bee Chin Ng, and Vanita Seth. I would also like to thank Professor Andrew Gerstle for his many useful comments. I am grateful to Dr. Sandra Wilson for her meticulous reading of the manuscript and her many suggestions. My thanks also to an extremely rigorous anonymous referee, whose many suggestions and criticisms I have tried to incorporate. Needless to say, all shortcomings of the work are my responsibility.

I cannot thank Sanjay Seth enough for his companionship and his unstinting generosity in reading successive drafts of the book and refusing to be easily persuaded by its arguments. The good humor and cheerfulness of my son Nishad did much to alleviate the depression of bad writing days.

Finally, I would like to thank the following institutions for their support: the Japan Foundation for a dissertation fellowship, the Australian National University for a dissertation scholarship, and La Trobe University for a semester's sabbatical leave to complete the 
manuscript. Chapter three draws upon material previously published in the Journal of the Royal Asiatic Society under the title, "Love, Poetry and Renunciation: Changing Configurations of the Ideal of Suki." I am grateful to the Journal of the Royal Asiatic Society for permission to use this material. 



\section{Introduction}

In Japan there was no written literary tradition predating the advent of Buddhism, and the introduction of a written script from China went hand in hand with the encounter with Buddhist canonical writing. The earliest attempts to grapple with the written word took the form of reading Buddhist sutras written in Chinese. Thus, from the beginning, the aesthetic tradition that emerged was already being shaped by Buddhist ideals and practices.

The emergence of this religio-aesthetic tradition, in which aesthetics could not be defined outside of Buddhism, did not take place, however, in an unproblematic and unselfconscious manner. A potential conflict manifested itself when Japanese writers sought to consider what the implications of the act of writing, seen as a fundamentally worldly pursuit, were for the goals of detachment and renunciation central to the experience of Buddhist enlightenment.

Doubts about the value of "worldly" writings, as well as the possibility of the resolution of these doubts, had already been debated by litterateurs in China. Their writings played no small part in the Japanese understanding of the possibilities and limitations of literary endeavor within a predominantly Buddhist context. Thus the history of literary writing in medieval Japan is punctuated by a series of explorations of this tension between writing, which was seen as a form of attachment, and the goal of renunciation. The engagement with this problem, and the conscious attempt to overcome it, generated an aesthetic that could not be understood outside the realm of the religious. However, the reconciliation was never a given and was achieved only through considerable debate regarding the relationship between the two and through theorizing about both their separation and their indivisibility. 
In this work I seek to explore one such moment of engagement with the question of the nature, role, and validity of artistic pursuits, posed in relation to an ideal Buddhist vision, through a study of one of the most important literary figures of medieval Japan, Kamo no Chōmei (1155-1216). There has thus far not been a monograph-length study of Kamo no Chömei in any Western language; this despite the fact that one of his works, Hojjoki (An Account of My Hut), forms part of the Japanese literary canon and is essential reading for all Japanese high school students even today. Thomas Hare's lengthy article on the works of Kamo no Chomei in the Harvard Journal of Asiatic Studies is an important contribution to an otherwise neglected area of research. ${ }^{1}$

Chomei has left behind a wide range of writings: his personal collection of poetry, Kamo no Chōmei shū; a treatise on poetry called Mumyōshō (Nameless Notes); a collection of exemplary Buddhist tales, Hosshinshū (Collection of Tales of Religious Awakening); and a "personal" account of his life as a recluse, Hōjöki. Apart from Kamo no Chōmei shū, all of Chōmei's major writings were composed after he went to Hino to live the life of a Buddhist recluse. Mumyōshō is believed to have been completed sometime around 1211. There is considerable debate, however, regarding the exact dates of composition of Hosshinshu and Hōjōki. Many scholars argue that Hōjoki was completed in 1212 and Hosshinshu in 1214 or 1215 . There is also some debate about the variant extant texts of Hōjōki. For example, the enlarged version of Hōjōki (Kohon Hōjōki), which we have used here, and which Chömei signed with his religious name, Ren'in, is believed to have been composed after the shorter version of the text (Ryakuhon Hōjöki). ${ }^{2}$ While keeping in mind these textual debates, we have not found it necessary to enter into them. We shall be reading Chömei's texts as engagements with the nature of literary writing and its place in the religious life rather than as providing an intellectual biography, with all its teleological implications of personal growth.

As a person who straddled both the artistic and religious worlds-he spent most of his life at court as a poet and musician but in his later years chose to become a Buddhist priest and to

1. Thomas Blenman Hare, "Reading Kamo no Chōmei," Harvard Journal of Asiatic Studies 49.1 (June 1989): 173-228.

2 . Indeed, there is even some disagreement about the authorship of Hosshinshu itself, although most scholars today do treat the work as a text compiled by Chōmei. 
live as a recluse away from the capital—Chōmei was ideally placed to explore the tension between the pursuit of artistic practices and the goal of renunciation. This book does not attempt a textual exegesis of all of Chōmei's writings. Rather, his texts are interrogated for what they have to tell us about the complex interaction between Buddhist philosophy and aesthetic practices; the debate regarding aesthetics and renunciation is central in Chōmei's works.

In giving expression to this dilemma, Chōmei was, of course, not alone. Both those who were first and foremost writers and poets and those who were priests committed to the propagation of the Buddhist faith gave voice to this tension. Indeed, the debates surrounding the legitimacy of literary writing had existed in Japan for at least two centuries before Chōmei took up his brush. While the continued presence of these debates suggests an ongoing engagement with what was perceived to be a genuine dilemma, the debate itself became a well-established literary trope and a conventionalized mode of talking about the act of writing. There developed an entire corpus of writing tied together through the bonds of the intertextual exploration of this familiar theme. Kamo no Chomei's engagement with the issue of the meaning and context of literary writing, therefore, cannot be seen simply as the idiosyncratic and individual angst of an exceptional writer. His writings are rooted in a tradition in which such engagement had become part of literary convention. At the same time, the fascination of Chomei's work lies in part in the fact that he approached this question with considerable intellectual passion and rigor. His writings reflect the attempts of one individual to think through with renewed seriousness issues that were deemed important by many writers of the period.

There has not been sufficient detailed work either in Japanese or in Western languages that examines the process whereby a religio-aesthetic ideal took shape and became central to medieval Japanese writing. ${ }^{3}$ The reasons for this can be traced back to the Tokugawa period, which saw a concerted effort toward the creation of a category of "Japanese literature" through the exclusion and rejection of Chinese influences. The beginnings of this move toward the exclusive study of indigenous literature are as-

3. One important contribution toward opening up this debate among scholars in the English-speaking world was William R. LaFleur's The Karma of Words: Buddhism and the Literary Arts in Medieval Japan (Berkeley: University of California Press, 1983). 
sociated with a group of scholars who came to be called wagakusha (scholars of Japanese). These scholars rejected classical Chinese and became fervent exponents of Shinto and of the national language and literature. Their study of Japanese culture came consciously to exclude Buddhism and Buddhist influences. Their ideological and literary prejudices therefore relegated whatever could be identified as Buddhist in medieval literature to a place either not properly literary or not really Japanese. By the eighteenth century the wagakusha were a formidable intellectual force, including among their numbers distinguished scholars such as Kamo no Mabuchi (1697-1769) and Motoori Norinaga (1730-1801). During this time Buddhist scholarship, which had always been engaged in the recovery and interpretation of Buddhist texts, continued. This work was undertaken chiefly by scholars who belonged to the priesthood, in the isolation of Buddhist institutions, and in a sense in opposition to the growing scholarly interest in nativist literature and culture.

Thus, during the Tokugawa and Meiji periods there developed what might be called two traditions of scholarship, the one dealing exclusively with "Buddhism" and the other with "literature." It was inevitable that the rigid division between these two streams of scholarship would be questioned at some later stage. Over the last few decades many scholars of Japanese literature have argued that in order to examine meaningfully the writings of the Heian, Kamakura, and Muromachi periods, it is no longer possible to study "Buddhism" or "literature" in total isolation, even if they had hitherto developed as two mutually exclusive disciplines.

One landmark in this new endeavor was an academic conference held in 1962 called the Bukkyō Bungaku Kai (Conference on Buddhist Literature). However, the combination of the two terms Buddhism (bukkyō) and literature (bungaku) opened up a number of contentious issues. The journal Bukkyō bungaku kenkyū published an issue devoted to the notion of bukkyō bungaku. The major question raised by the majority of the papers in this issue was, What is bukkyo bungaku? Predictably the response was far from unanimous. ${ }^{4}$

4. There was little agreement on what constituted "literature" and how it was to be distinguished from "Buddhist literature." If every text that had considerable Buddhist words and ideas could be categorized as Buddhist literature, on what basis could a distinction be made between works such as Genji monogatari and, say, the Tannishō (Col- 
Despite the subsequent attempts by many scholars from both the "Buddhist" and "literature" sides to work together, there continues to be a very real division between the koku bungakusha (the heirs of the wagakusha) and the bukkyo gakusha. ${ }^{5}$ Most departments of literature in Japan continue to be dominated by nativist scholars (koku bungakusha). Japanese literature is still generally seen as something distinct from Buddhism, although it may be granted that this literature does on occasion reflect Buddhist themes and ideas. It is not surprising, then, that scholars working on Kamo no Chōmei's writings have sought to interpret him either as a major literary figure or as a good Buddhist.

It is ironic that contemporary scholarship frequently compartmentalizes the writings of Heian and Kamakura Japan in this fashion, for what was particularly striking about the literature of these periods in Japan is precisely the absence of this kind of rigid distinction. While today the scholars of Buddhism and scholars of literature are to be found in separate institutional settings, the world of the litterateur and that of the priest overlapped to a considerable degree in the twelfth and thirteenth centuries. Priests as well as court poets engaged in literary activity. It was an age in which the court poet Fujiwara no Teika (1162-1241) composed (among other things) twenty-four poems based on the Lotus Sutra, and the Tendai abbot Jien (Jichin, 1155-1225) composed love poetry.

The literary works of the twelfth and thirteenth centuries cannot be read as separate from and outside of their Buddhist epistemological framework. It was within the confines of a Buddhist view of the world that literary activity was conducted, and it

lection Inspired by a Concern over Heresy), other than perhaps by quantifying the Buddhist content? See Bukkyō Bungaku Kenkyūkai, ed., Bukkyō bungaku kenkyū, vol. 12 (Kyoto: Hōzōkan, 1973). Or if we are to follow the opinions of another writer in this collection, any work that expresses even an iota of doubt in Buddhism, that is to say, is not premised on unquestioning faith in the precepts of the religion, is not Buddhist even if it may be literature. See Ide Tsuneo, "Bukkyō bungaku to sō de nai mono," in Bukkyō bungaku kenkyū, 12:57-70.

5. It is not surprising, then, that in describing the seminar one scholar pointed out that the bulk of the participants were koku bungakusha but that there were a sizeable number of bukkyo gakusha as well. See Abe Akio, "Bōzen to shita kitai," in Bukkyō bungaku kenkyū, 12:78. 
was within a Buddhist context that debates regarding the nature and value of writing were conducted. This study seeks to restore the theme of the tension between writing and renunciation that is a central feature of medieval writing and that informs a great deal of Chōmei's writings.

Chapter one is a detailed study of a variety of writings from the Heian and Kamakura periods, examining the ways in which a confrontation between literary traditions and Buddhist ideology is posed, and reflected more widely, in the literary productions of those times. I also try to indicate the diverse resolutions that authors put forward, resolutions that in some instances made it possible for them to continue with their artistic activities while being good Buddhists. The term kyōgen kigo (wild words and fancy phrases), the Buddhist proposition shojji soku nehan (samsara is nirvana, i.e., rebirth is extinction), the notion of höben (expedient means), and the ideal of suki (single-minded devotion to an art) were only some of the many conceptual tools used by Japanese writers in attempting to clarify the place of the arts, and of poetry in particular, within a world increasingly dominated by Buddhism.

Chapter two is a brief biography of Chōmei. While little is known about the lives of many well-known writers of the Heian and Kamakura periods, Chōmei is something of an exception, for there is a wide range of material that sheds light on his life. By looking at the diaries and literary works of his contemporaries, I attempt to recreate the social and cultural milieu in which he lived and worked. (Appendix one is a translation of an excerpt from the diary of Minamoto no Ienaga, Minamoto no Ienaga nikki, that discusses events in Chōmei's life.) This chapter also focuses on Chōmei's activities as a court poet and the particular circumstances that led him to leave the capital and take the tonsure.

Chapter three is a study of Chōmei's treatise on poetry, Mumyōshō. In Mumyōshō Chōmei draws upon a wealth of anecdotes and folklore to construct his vision of the ideal poet. To do this, Chōmei singles out one aesthetic ideal, suki. In the Heian period, suki signified a commitment to amorous sport and the pursuit of such sport through the refined pastimes of music and poetry. By Chōmei's time, the term had lost its amorous connotations and had come to be redefined as a single-minded dedication to a single artistic discipline. I argue that in Mumyōshō the ideal of suki is central to Chömei's definition of the serious poet committed to the way of poetry. In this work, composed after Chomei took the tonsure, suki is harnessed to the project of creating a 
well-defined tradition for waka practice, a project shared by many of his contemporaries.

Chapter four is devoted to Chōmei's collection of tales about monks and recluses, Hosshinshu. While much of the work consists of stories about monks who have withdrawn from the world and who grapple with perfecting the prescribed Buddhist practices, there is one section that seeks to establish that certain aspects of courtly culture are inseparable from the conditions necessary for Buddhist enlightenment. It is this section that is the central focus of this chapter. The ideal of suki, which is present in Mumyōshō, reappears in Hosshinshū and acquires a different signification in the new context in which it is deployed. Through subtle reworkings of the concept of suki and stretching the range of its semantic possibilities, Chomei is able to validate not only the courtly values of refinement and sensitivity, but more importantly the practices of poetry and music. Chomei's argument in Hosshinshu is that it is precisely the cultivation of these arts, that is to say the pursuit of the ideal of suki, that creates the state of purity and detachment upon which Buddhist salvation is dependent. (Appendix two presents a selection of translations of stories from Hosshinshü.)

The final chapter of this study examines Chōmei's bestknown work, Hōjōki. Hōjöki has generally been interpreted as an autobiographical account of Chōmei's life as a recluse, in which he agonizes over his inability to transcend worldly attachment or, conversely, successfully resolves the tension between attachment and renunciation. Hōjok $i$ is, of course, much more than a straightforward autobiography. It is first and foremost a literary text that self-consciously models itself upon a variety of religious and literary texts such as the Vimalakirti Sutra and Chiteiki (Record of the Pond Pavilion). It is by alluding to these texts and reworking them that Chomei dramatizes both the harmony of and the potential tensions between the pursuit of music and poetry on the one hand and a firm commitment to the Buddhist path on the other. The chapter deals extensively with the various debates that surround the interpretation of the final section of Hojoki $i$ and argues that it is a complex text that, through an elaborate strategy of intertextuality, reworks the well-known theme and places it at the very center of its concerns. This book, then, is a study of the writings of one remarkable writer of the medieval period and of the themes of writing and renunciation that are central to the texts he left behind. 
The text that I have used in the study of Mumyōshō is the annotated edition that appears in the Nihon koten bungaku taikei series. ${ }^{6}$ This edition is based on a manuscript from the early Edo period, collated with other variant texts. My study of Hosshinshū and Hōjōki is based on the annotated text by Miki Sumito in the Shinchō Nihon koten shūsei series. ${ }^{7}$ Miki has used the Taifukukōji bon text of Hōjoki, which dates from the Kamakura period, and collated it with other texts, such as Ichijo Kanera bon, a variant manuscript of the Muromachi period. Miki's Hosshinshū is based primarily on the printed edition of this work dating from the year 1652 .

6. Hisamatsu Sen'ichi and Nishio Minoru, eds., Mumyōshō, in Karonshū, Nihon koten bungaku taikei, no. 65 (Tokyo: Iwanami Shoten, 1961); hereafter $M Y$.

7. Miki Sumito, ed., Hōjōki, Hosshinshü, in Shinchō Nihon koten shūsei (Tokyo: Shinchōsha, 1976); hereafter HK and HS. 


\section{Chapter One}

\section{"Wild Words and Fancy Phrases": Debates on the Role of Literature in the Heian and Kamakura Periods}

When the Chinese poet Po Chü-i (772-846) dedicated a collection of his poetry, the Loyang anthology, to the Hsiangshan temple in Soochow in 839, he appended to it the following apologia: "May the worldly writings of my present incarnation, all the wanton talk and fine phrases, be changed into a hymn of praise that shall glorify the doctrines of the Buddha in age on age to come, and cause the Wheel of Law forever to turn." 8

Po Chü-i could not have imagined the impact his statement would have, two hundred years later, on litterateurs in Japan. His phrase k'uangyen iyu (wild words and fancy phrases), ${ }^{9}$ which was rendered as kyōgen kigo or kyōgen kigyo in Japanese, became a popular catchphrase in the Heian and Kamakura periods, encompassing both a censure of creative writing on religious grounds and, paradoxically, a justification of it that was also based on Buddhist doctrine. The phrase provided one way to articulate and resolve the tension between an engagement with "words" and a commitment to the ideals of Buddhism.

The Buddhist attitude toward words, whether written or spoken, ${ }^{10}$ was marked by a sense of deep ambivalence. Buddhism

8. Arthur Waley, The Life and Times of Po Chü-i, 772-846 (London: Allen and Unwin, 1949), 193-94.

9. I have chosen to translate kyōgen kigo as "wild words and fancy phrases" throughout the text.

10. As James Liu has pointed out, the Taoist view of language stands in marked contrast to the phonocentrism or phonologism of Western thought, which favors speech over writing. The Buddhist view of language shares with Taoism a mistrust of both the spoken and the written word. See James J.Y. Liu, Language-Paradox-Poetics: A Chinese Perspective (Princeton: Princeton University Press, 1988), 15. 
placed particular emphasis on the idea that the absolute could not be understood through reasoning but had to be experienced. It was precisely because it could only be intuited through experience that it could never be communicated through words. Thus words were seen as essentially inadequate to the task of capturing the absolute, which was beyond all language and all thought. And yet there was a recognition that, at the level of the phenomenal world, words were all we had and that it was necessary to use them, however unsatisfactory they might be, in order to preach the Buddhist teachings.

At the heart of the Buddhist view of the nature of language, then, lay a paradox. For instance, the story of Buddha Sākyamuni picking a flower for his disciple Kāsyapa, who smiled with immediate understanding, was meant to demonstrate the communication of an ultimate truth, one that transcended words. Yet it was only through the use of words that the ultimate inadequacy of words could be communicated to human beings. The same paradox is to be found in the Vimalakirti Sutra, in the famous "silence of Vimalakirti." When asked to define nonduality by Mañjuŝrĭ, Vimalakỉrti does not utter a word. Mañjuśrī applauds him, saying, "Excellent, excellent; can there be true initiation into the non-dual Dharma until words and speech are no longer written or spoken?"11 Again it is by taking recourse to language that the Vimalakirti Sutra attempts to teach the wisdom of Vimalakirti to ordinary men and women.

The Zen sects of Buddhism, which placed particular emphasis on religious practice and spiritual experience, rather than on scholasticism, refused to rely on the canonical texts on the grounds that, since they were based on words, they were in the end only poor representations of the ultimate truth, which was ineffable. However, for the most part it was granted that the sutras were an invaluable expedient means (höben, Sanskrit upaya) of leading human beings to enlightenment.

Po Chü-i's phrase k'uangyen iyu captured precisely the paradox seen to be inherent in the use of language. The two terms had been used separately in China, and no one before Po had used them in conjunction. K'uangyen was a term used by Chinese writers at least as early as Chuang Tzu to describe any sort

11. Charles Luk, trans. and ed., The Vimalakirti Nirdesa Sutra (Berkeley: Shambala, 1972), 100. 
of nonsensical, irrational, or trivial talk. ${ }^{12}$ The idea that language is inadequate to the expression of the Ultimate and the assertion of this inadequacy through the medium of language were prominent features of Chinese philosophical texts of the Taoist school. For example, Lao Tzu, while claiming that the Tao could not be named, attempted to do so in various ways. Po Chü-i commented on this in his quatrain "On Reading Lao Tzu":

"One who speaks does not know; one who knows is silent":

This remark I have heard from the Old Master.

If you say the Old Master was one who knew,

Wherefore did he himself write his "Five Thousand Words"? ${ }^{13}$

The term iyu (fancy phrases) was one of the four sins of the word (kogō) to be found in the list of ten evils (jüaku) proscribed by Buddhists. In the Sukhãvati Sutra (Array of the Happy Land Sutra), for example, we find the injunction against iyu listed as one of the four sins of the word, the others being falsehood (mögo), equivocation (ryōzetsu), and slander (akkō). The Avatamsaka Sutra (Flower Wreath Sutra) describes how a person who committed any of these sins would be sentenced to hell, to rebirth as an animal, or to life in the world of the hungry ghosts. These sutras inveigh against particular kinds of writing. Ornate words, for example, were seen as having a seductive power that could mislead human beings. For this reason they were criticized together with such sins of the word as falsehood and slander. However, these texts, embroiled as they themselves are in words, do not offer a thoroughgoing critique of the act of writing itself.

The Lotus Sutra, for example, limits itself to condemning specific kinds of writing that go against Buddhist practice; at the same time it endorses writing that praises the Buddhist dharma. Thus in the fourteenth chapter of the sutra, we have the following criticism of writing:

The bodhisattva-mahāsattva does not approach with familiarity kings or princes of realms, nor ministers or senior officials. He does not approach with familiarity the

12. An influential Taoist text attributed to Chuang Tzu in the fourth century B.C. See Burton Watson, trans., The Complete Works of Chuang-Tzu (New York: Columbia University Press, 1968).

13. See Liu, Language-Paradox-Poetics, 7. 
followers of external paths, nor Brahmans, nor Nirgranthas, nor those who compose worldly letters, nor those who sing the praises of external writings, nor Lokāyatas, nor those who opposed the Lokāyatas. ${ }^{14}$

In the chapter "Hōben bon" (Expedient Devices), however, art, music, and song are extolled in verse:

If any persons, in stūpas and mausoleums,

To jeweled images and painted images

With flowered and perfumed banners and canopies And with deferential thoughts make offerings,

Or if they cause others to make music, Beating drums and blowing horns and conchs,

Or sounding flutes, of many reeds or of only one, and lyres, mounted on stands or not, And lutes and cymbals,

Producing many fine sounds like these And holding them all up as offerings;

Or if with joyful thought

They sing hymns of praise to the excellences of the Buddha, Producing so much as one tiny sound,

They have all achieved the Buddha Path. ${ }^{15}$

There is no doubt that Japanese writers were well aware of the dilemma inherent in the act of writing. However, this did not lead to a renunciation of writing itself. Instead, solutions to this dilemma were sought and found within Buddhist doctrine. A general consensus gradually emerged that the role and validity of literature in relation to Buddhism had to be clearly defined, and Po Chü-i's statement provided one response to this question.

There was a wide range of responses in the Heian and Kamakura periods to the problem of affirming literary writing while at the same time integrating it within the epistemological framework provided by Buddhism. Kamo no Chōmei, clearly, was not alone in attempting to achieve such a synthesis between artistic

14. Leon Hurvitz, trans., Scripture of the Lotus Blossom of the Fine Dharma (The Lotus Sutra) (New York: Columbia University Press, 1976), 208. See also, Michele Marra, The Aesthetics of Discontent: Politics and Reclusion in Medieval Japanese Literature (Honolulu: University of Hawaii Press, 1991), 55-56, for a discussion of the attitude to secular writing in the Lotus Sutra.

15. Hurvitz, Scripture of the Lotus Blossom, 39-40. 
and religious practices, and his response cannot be understood in isolation. This chapter seeks to analyze the strategies employed by Chōmei's contemporaries, as well as by those who came before him, to bring together what were often seen as disparate and yet closely linked ideals. It is by contextualizing this ongoing debate that Chōmei's own contribution can be better understood.

By the fifth century, public documents, written in Chinese, were being exchanged between the Yamato state and China. However, writing was used in the fifth and sixth centuries chiefly to keep accounts and registers or send dispatches to foreign courts. The Japanese themselves had not come to grips with the Chinese language, and the task of writing was assigned to scribes of Chinese and Korean origin. The mastery of Chinese was a long and painful process, and the attempt to represent Japanese words with signs for Chinese words was far from easy, given the very different nature of the two languages. ${ }^{16}$ The fact that writing in Japan was associated from the very beginning with the more "advanced" Chinese cultural and philosophical traditions must have contributed in no small measure to the exalted status of the written word.

Kojiki (Record of Ancient Matters, 712) and Nihon shoki (Chronicles of Japan, 720) were the earliest attempts in Japan to produce national histories. The very notion of writing a history was inspired by Chinese example, and the only language available for doing so was Chinese. The total dependence on Chinese in the creation of a written culture meant that the Japanese sought precedents for their own works within Chinese writings. It meant also that they inherited their cultural mentors' strong Confucian view of writing as a vehicle for promoting virtue and chastising evil.

It is not surprising then, given the exalted status of Chinese as the bearer of new ideas and concepts, that the term kyogen kigo, and the articulation of the notion that literary writings were sinful, came from China. Japanese scholars of Chinese in the Heian period, who had greater familiarity with Confucian texts and classical Chinese poetry, were instrumental in clarifying the aesthetic and philosophical underpinnings of Chinese texts.

16. Roy Andrew Miller, The Japanese Language (Chicago: University of Chicago Press, 1967). 


\section{Po ChU-1 and K'UANGYEN IYU}

Undoubtedly the single most influential Chinese poet in Japanese literary circles in the Heian period was Po Chü-i. Po himself notes that his Po Chü-i ch'uan-chi (Collected Works) made its way to Japan. It is not clear exactly when his poetry first appeared in Japan; a note appended to the text by Po Chü-i on the first day of the fifth month of 845 mentions the fact that the Japanese pilgrim Jikaku, fleeing from China disguised as a layman, took a copy of the text with him in his luggage. For centuries to come Po's writings were referred to simply as the Collection in Japanan indication of the uncontested status of this literary figure. ${ }^{17}$ The fortuitous circumstances that brought Po Chü-i's works to Japan established him as the Chinese literary authority par excellence. The other great eighth-century poets of China were hardly known in Japan-Li Po's (701-62) works receive mention at the end of the ninth century, but he was known only among a restricted circle of scholars. Tu Fu (d. 770) remained unknown probably until the fourteenth century.

Po Chü-i's own attitudes regarding the role and validity of literature were shaped by traditional Confucian principles. In a letter to his close friend Yuan Chen in 815, Po discussed the "main principles of poetry" and his own "literary intentions." 18 Here he merely restated a position that had become part of the orthodoxy of the Chinese literary tradition. Po Chü-i reserved the highest praise for poetry that carried a moral or political meaning-poetry that was not an end in itself but rather a means to order the state by instructing it in the art of good government. For Po, Shihching (Book of Songs), the first anthology of Chinese poetry, compiled around 600 B.C., stood at the pinnacle of this ideal. ${ }^{19}$ The songs, he claimed, expressed directly or allegorically the griev-

17. Murasaki Shikibu, in her diary, mentions that she would secretly read the two books of "ballads" with the second empress, Shōshi. The ballads she refers to are contained in chapters three and four of Po's collected works as they have been preserved today. See Waley, Life and Times, 212-13.

18. The following discussion of Po's views on literature is based on the information provided in Waley, Life and Times, 107-13.

19. Arthur Waley, trans., The Book of Songs (London: Allen and Unwin, 1937. Reprint 1969). See Burton Watson, trans, and ed., The Columbia Book of Chinese Poetry: From Early Times to the Thirteenth Century (New York: Columbia University Press, 1984). 
ances of the people and could be used by the rulers of China to redress injustices. Po lamented the subsequent decadence in poetry. He saw the sixth century as the period when poetry lost all social relevance and became entirely an individual sport of clever verbal contrivances. As he put it, poetry became mere "sporting with wind and snow, toying with grasses and flowers."

Turning to his own work, Po spoke of his growing commitment to writing poetry with a political message, a commitment that developed when he received a post at court: "It was then that I reached this conclusion: the duty of literature is to be of service to the writer's generation; that of poetry to influence public affairs." Ironically, however, it was not Po Chü-i's political poetry that received the highest praise from his contemporaries. Po complained about this in his letter to Yuan Chen. He explained the four categories into which he divided his own poetry: first, the didactic poems with a social and political purpose; second, the meditative poems written to express personal moods and feelings; third, the "poems of sorrow," which included elegies on the deaths of friends and laments on misfortune; and fourth, the "miscellaneous poems," written simply to express some fancy of the moment or to "enhance the pleasure of meetings and dissipate the gloom of farewells." Po lamented the fact that it was only his poems in the last category that had received attention. Po told the story of a singing-girl who put up her price on the ground that she could sing his poem "Song of Everlasting Sorrow." ${ }^{20}$ This poem, too, belonged to the last category, which, according to Po, included poems that he did not value at all and which he would be quite happy to see left out of his collection, if some future editor wished to do so. In Japan there was no interest at all in Po's political poetry, and "Song of Everlasting Sorrow" was as popular with the Japanese literati as it had been with the singing-girl and her patrons.

It is presumably to apologize for his "miscellaneous" and "meditative" poems that Po Chü-i employed the term k'uangyen iyu. For Po Chü-i, no justification of his political and social poems was necessary, since these conformed to Confucian notions of morality. The term $k^{\prime} u a n g y e n ~ i y u$ did not have its roots in Confucian literary criticism. It was within a Buddhist context that Po Chü-i first used this phrase.

20. Dore J. Levy, trans., Chinese Narrative Poetry: The Late Han through T'ang Dynasties (Durham: Duke University Press, 1988), 129-33. 
Po Chü-i was representative of many Chinese poets of the time who were good Confucians in their public lives, but who in their private lives were drawn to Taoist and Buddhist practices. Po appears to have shown considerable interest in Buddhist philosophy from his youth, but it was only in his later years that he seems to have become more involved with following the Buddhist faith. This is reflected in the poetry he has left behind. He addressed several of his poems to Buddhist monks and, as we mentioned earlier, dedicated his works to Buddhist monasteries. Both his belief that poetry could serve religious ends and his doubts about the value of poetry are recurring themes in his own writing. We know that he studied the Avatamsaka Sutra with the monk Tao Tsung. In a piece devoted to this monk, Po wrote that the Buddha uttered hymns of praise and the bodhisattvas wrote religious treatises, but Tao Tsung wrote poetry because he considered it an effective means of communicating with the literati and converting them to Buddhism. This was also what motivated Po to dedicate a collection of his own literary works to monasteries.

In a poem written as early as 817 he wrote:

Ever since I practiced assiduously the method leading to the Gateway of the Void,

I have dispelled the various kinds of mental perturbation up to now.

Only the demon of poetry is not conquered.

Whenever the gay moment arises, I take pleasure to chant. ${ }^{21}$

In 841 he expressed the same concern again in a poem that he sent to some monks and that he requested to have inscribed on the walls of his cottage in Lu-shan:

He that thirty years ago was master of this cottage-

Though today he is still in the world, his hair is white as silk... . He has gradually vanquished the Demon of Wine and does not get wildly drunk;

But the Karma of Words still remains; he has not abandoned verse. ${ }^{22}$

Yamada Shōzen examined the prayers that Po appended to the collection of his literary works that he dedicated to three

21. See Kenneth Ch'en, The Chinese Transformation of Buddhism (Princeton: Princeton University Press, 1973), 202.

22. Waley, Life and Times, 207. 
Buddhist temples. ${ }^{23}$ The first was to the Tung-lin monastery in Lushan in the year 835. The following year he dedicated another copy to the Shengshan monastery in Loyang. Finally, he presented his works to the Hsiangshan monastery at Soochow in 839 . Yamada argued that Po Chü-i did not consistently use the phrase $k$ 'uangyen iyu, and that even when he did use the two terms together, he did so merely as a rhetorical device, in which k'uangyen reinforced the idea already embodied in iyu. For example, Po's dedication of his works to the Tung-lin monastery, while otherwise identical to his dedication to the Hsiangshan temple, quoted above, used the term fangyen (högen), which could be translated as "irresponsible or thoughtless speech," instead of k'uangyen.

On the occasion of his dedication to the Shengshan monastery, Po did not use the words k'uangyen or iyu at all but merely expressed his desire that his worldly writings would be changed into a hymn of praise, glorifying the Buddha's doctrine. Yamada argues that for Po Chü-i the omission of the phrase was not a matter of consequence because the phrase only restated the notion of "worldly writings."

Po's writings reveal a Confucian concern about the political and social relevance of poetry; in this view, the main role of poetry was seen as lying outside itself. Art had value only if it could be harnessed to serve the government and to promote morality. This attitude may have contributed further to Po Chü-i's doubts about the compatibility of the pursuit of poetry with the observance of the Buddhist path. K'uangyen iyu was merely a convenient shorthand for expressing these concerns. In Japan, however, the phrase acquired a significance far beyond that intended by Po. The undisputed prestige of Po's works in Japanese literary circles meant that his formulation was taken by many as the authoritative answer to the problem of defining the role of poetry within a Buddhist framework.

\section{EarLy Formulations of KYōGen KIGo IN JAPAN}

The first extant use of the term kyoggen kigo appears in Minamoto no Tamenori's (d. 1011) collection of Buddhist tales, Sanbōekotoba (Three Treasures in Words and Pictures). According to the preface, it was written in 984 for the edification of Princess Takako, the second daughter of Emperor Reizei. She became the consort

23. Yamada Shōzen, "Kyōgen kigo seiritsu kō," Kokubungaku tōsa 14 (February 1956): 3-4. 
of Emperor En'yu but had to take the tonsure in 982 . She died three years later in 985 , just under twenty years of age. Tamenori's work was intended to teach this noblewoman the essentials of the three Buddhist treasures, namely, the Buddha, the dharma, and the priesthood. It was originally accompanied by illustrations, but the work in its many recensions survives today without its pictures. In one section there is a description of what is for us a significant event-the first meeting between scholars of Chinese and members of the Tendai priesthood. ${ }^{24}$ This meeting was known as the Kangakue (Service for the Advancement of Learning).

Tamenori describes how during the reign of Emperor Murakami, in the year 964, some students of the national university, set up in the Nara period in emulation of T'ang institutions, expressed a desire to establish a bond with the Tendai monks of Mount Hiei. The purpose of the meeting, they said, was to encourage mutual exchange between the way of the dharma (nori no michi) and the way of Chinese learning (fumi no michi). On the evening preceding the appointed day, the monks descended from the heights of Mount Hiei, while those who belonged to the secular world (zoku) climbed up from Sakamoto. The scholars of Chinese chanted a verse by Po Chü-i as they made their way up. When they reached the top they were met by the Tendai priests, who intoned a verse from the Lotus Sutra. On the following morning they began the Kangakue with lectures on the Lotus Sutra; in the evening they chanted nenbutsu, and this was followed by spending the whole night singing verses in praise of the Buddha and the dharma. Poems were composed on topics taken from the Lotus Sutra. These poems, known as the Nijuhapponka (Poems on the Twenty-Eight Chapters of the Lotus Sutra) were to become, as we shall see, an important part of the poetic tradition of waka. These poems were then presented to the temple in the manner of Po Chü-i's own dedications, and his plea-namely that his worldly writings, the wild words and fancy phrases that constituted his poetry, be turned into a hymn of praise-was recited. The monks also recited various stanzas from the Lotus Sutra through the night.

24. See Koizumi Hiroshi and Takahashi Nobuyuki, eds., Sanbōeshūsei (Tokyo: Kazama Shoin, 1980), 278-79. For a fine study of this text, see Edward Kamens, The Three Jewels: A Study and Translation of Minamoto Tamenori's Sanbōe, Michigan Monograph Series in Japanese Studies, no. 2 (Ann Arbor: Center for Japanese Studies, The University of Michigan, 1988). 
Tamenori concludes that everyone present was deeply moved and shed tears listening to the monks reciting the wondrous stanzas from the sutras and the lay poets reciting Chinese poetry.

There are several features of the Kangakue that are worthy of note. First, the initiative came from scholars who belonged to the prestigious national university, which specialized in Chinese history, classics, and poetry. The fact that these scholars wished to come out of their well-established and learned Confucian institution and interact with the Buddhist clergy for the mutual appreciation of poetry and Buddhism is a remarkable index of the ascendancy of Buddhist values and ideals in that society. The gathering was inspired by a similar ceremony that took place twice a year at the Confucian university and that was dedicated to the worship of Confucius and his ten disciples. On the night before the ceremony, lectures were given on the Confucian classics and offerings made to Confucius that were distributed on the following day among those attending the ceremony. This was followed by the composition and recitation of Chinese poetry. In the Kangakue ceremony the lectures on the Lotus Sutra were substituted for lectures on the Confucian classics.

More significantly there was an acknowledgment on the part of Japanese poets composing in Chinese that only poetry that addressed itself directly to Buddhist concerns, poetry that could be harnessed to the Buddhist cause, could become part of what was essentially a Buddhist enterprise.

The initiative for the Kangakue, as mentioned earlier, came from the scholars of Chinese. The Tendai monks would not have needed to gain the support of these scholars, given the security of the religious world they inhabited. The scholars, however, by undertaking the ascent from Sakamoto to the mountain temples, attempted to bridge the gap between their worldly existence (zoku) and the spiritual world of Buddhism. It was in this context that Po Chü-i's phrase kyōgen kigo acquired a special significance. The presence of poetry as an important part of Buddhist practice had to be explained and justified, and to do this the scholars of Chinese clearly found a convenient precedent in Po's own apologia.

Among the scholars who took part in the Kangakue were Yoshishige Yasutane (d. 1002), Ōe no Igen, Takashina Sekizen, Ki no Tadana, Tachibana Kihei, and Tamenori. Many participants acknowledged that the content and purpose of their poetry had to change, and they felt strongly committed to effecting such change. This can best be seen in the writings of Yoshishige Yasutane. 
Yasutane was the son of Kamo no Tadayuki and belonged to a family of yin-yang scholars. He showed a deep interest in Chinese learning from an early age, becoming a pupil of Sugawara no Buntoki, from whom he learned Chinese poetry. Yasutane's early compositions show his mastery of Chinese techniques of versifying. In this period he abandoned himself to the pleasures of poetry, and nowhere in these writings does he betray any sense of unease over his poetic activities. It was Yasutane's growing interest in Tendai Buddhism, and particularly the Jodo teachings within it, that led him to initiate the Kangakue. The subsequent deepening of Yasutane's religious commitment brought about an important change in his literary activity. He wished to establish an important place for poetry in religious ceremony. Not only did he introduce the practice of composing and reciting religious poetry at the Kangakue, he also urged that poetry praising the Buddha be composed in other forums in which lectures on the Lotus Sutra took place, such as the Gokurakue (Service for Attaining Rebirth in the Pure Land). ${ }^{25}$

Yasutane dismissed poetry that had as its sole motive the spirit of diversion and that employed wild words and fancy phrases as rhetorical devices used for their own sake. In one of his poetic compositions, for example, he speaks about the poetic conceits used by poets who in their verses likened the cherry blossoms to the snow and the chrysanthemums to gold. For these poets, he argues, there is no escape from the sin of using false words (mōgo) and fancy phrases (kigo). Deluded beings often cannot help feeling drawn to such activities, yet they are in secret fear of the retribution they will receive for these sins. For this reason, Yasutane claims, he has given up literary pursuits and turned instead to praying to the Buddha. ${ }^{26}$

However, as Yasutane's works such as Chiteiki (Record of the Pond Pavilion) indicate, he continued to enjoy the pleasures of poetry in his private life in much the same way as Confucian bureaucrats like Po Chü-i enjoyed the more Taoist pleasures of wine, women, music, and poetry in their personal world, away from their official duties. In the case of Yasutane, this kind of

25. Yamada Shōzen, "Kyōgen kigo no ni sokumen: Yoshishige Yasutane no shi kan no hensen to Tendai kyōgaku to no renkan," Buzan gakuhō 5 (March 1959).

26. Kakimura Shigematsu, ed., Honchö monzui chūshaku (Tokyo: Tōyamabō, 1968), 2:799. 
dual existence ultimately proved unsatisfactory, for in the year 987 he took the tonsure and became a disciple of the Tendai master Genshin (942-1017). There is no evidence of his engaging in poetic activities after his joining the priesthood. Yamada Shōzen believes that it can be assumed that, like Genshin and other disciples of Jödo Buddhism, Yasutane adopted an increasingly severe attitude to the composition of poetry. The Jōdo sect of Tendai Buddhism best represented the view that literature had no intrinsic value but that it could, on occasion, be used as an expedient means. It is perhaps for this reason that the phrase kyoggen kigo was first taken up in Japan by those who were most influenced by Jōdo teachings. ${ }^{27}$

The term kyōgen kigo, together with the sentiments Po Chü$i$ used it to express, became popular among a larger section of the court aristocracy, not through the Chinese writings of the Kangakue, but rather through a song (rōei) that was included in Wakan rōeishu (Collection of Chinese and Japanese Poems for Singing, 1018), compiled by Fujiwara no Kintō (966-104 1). Po Chü-i's plea was rendered into the following song in this work:

negawaku wa konjō sezoku no monji no gō

kyōgen kigyo no ayamari o mote

kaeshite tōrai seze sanbutsujō no in

tenbōrin no en to semu.

I wish that the karma of secular writings,

That I compose in this life,

The errors of wild words and fancy phrases,

Be changed into a means to praise the Buddhist Vehicle

In age on age to come,

And effect the turning of the Wheel of the Law. ${ }^{28}$

Yamada offers evidence to suggest that Fujiwara no Kintō also took part in the Kangakue and that he composed poems based on the Lotus Sutra. This explains the inclusion of Po Chü-i's statement, in the form of a song, in the collection he compiled. Writers of Chinese prose and poetry in the Heian period, then, were the first to address the problem of situating literary endeavors in a Buddhist context, and they found in Po Chü-i's statement a way of articulating both the dilemma and its possible solution.

27. Yamada, "Kyōgen kigo no ni sokumen," 138-39.

28. Ōso Neshōsuke and Horiuchi Hideaki, eds., Wakan rōeishū, Shinchō Nihon koten shūsei (Tokyo: Shinchōsha, 1983), 222. 


\section{Prose Writing in JaPANESE}

Despite the unquestioned prestige and dominance of written Chinese in the public sphere, the tenth century witnessed a remarkable flowering of Japanese prose literature. An important impetus to this autochthonous growth was the evolution of the syllabary script (kana). The national university that had been set up in the Nara period in emulation of T'ang institutions and was devoted to Chinese studies lost some of its political importance with the growth of the power of the Fujiwara aristocracy. Actual contact with the unstable T'ang empire was also on the decline. The Japanese were now moving away from mere emulation of Chinese models, and what emerged was a more complex culture that incorporated native sensibilities and traditions as well as those that had been learned from the Chinese. Among the earliest prose works in Japanese was the literary diary by Ki no Tsurayuki (868-945), Tosa nikki (Tosa Diary), written around the year 935, which set the pace for many other writings in this genre. Kagero nikki (Gossamer Years), composed in the mid-tenth century, was one of the finest of the early works in this medium. By the first decade of the eleventh century, the flowering of Japanese prose fiction reached its apogee with the appearance of Genji monogatari (Tale of Genji).

One of the most interesting discussions of the nature of prose fiction-of the grounds on which it might be censured and the ways in which it could be defended-appears in the "Hotaru" (Fireflies) chapter of Genji. In a playful discussion with his protégée Tamakatsura, the hero, Prince Genji, having found her immersed in reading romances, first dismisses these tales as outright lies. He then proceeds to qualify this statement by admitting that the lies are so skillfully presented that the reader cannot help but take them for truths. In the end he enters into a more serious exposition on the subject, arguing against his earlier position and making a claim for fiction on grounds that are both Confucian and Buddhist. He says:

They [romances] have set down and preserved happenings from the age of the gods to our own. The Chronicles of Japan and the rest are a mere fragment of the whole truth. It is your romances that fill in the details. We are not told of things that happened to specific people exactly as they happened; but the beginning is when there are good things and bad things, things that happen in this life which one never tires of seeing and hearing about, things which one cannot bear not to tell of and must pass 
on for all generations. If the storyteller wishes to speak well, then he chooses the good things; and if he wishes to hold the reader's attention he chooses bad things, extraordinarily bad things. Good things and bad things alike, they are things of this world and no other. ${ }^{29}$

Genji explains that both good and bad things are integrally part of the world, and while there is a difference between the lighter and more serious forms of writing, or between old and contemporary fiction, to dismiss them as lies is itself to depart from the true nature of things. It is at this point that Genji turns to Buddhist doctrine to further strengthen his case:

Even in the writ which the Buddha drew from his noble heart are parables, devices for pointing obliquely at the truth. To the ignorant they may seem to operate at cross purposes. The Greater Vehicle is full of them, but the general burden is always the same. The difference between enlightenment and confusion [delusion] is of about the same order as the difference between the good and the bad in a romance. If one takes a generous view, then nothing is empty and useless. ${ }^{30}$

This passage reveals clearly Murasaki Shikibu's familiarity with reservations about fiction that were current at the time. It is to the Confucian argument that she addresses herself first of all. She points out that romances are in significant ways not different from the respectable national histories like Kojiki. They give flesh and blood and spell out at greater length what the chronicles merely sketch. Also they conform to certain accepted principles of morality and thus help promote virtue. And as they deal with both good and evil, both of which are undeniably present in this world, they are in a sense based on "fact."

Murasaki then turns to Buddhist doctrine itself in order to counter the Confucian-inspired accusation that fiction, unlike histories, amounted to no more than a falsehood. Within the Buddhist sutras too, lies (soragoto) were condemned as one of the ten sins of the word. Murasaki draws a parallel between fiction and the notion of hoben. She argues that fiction works as an expedi-

29. Abe Akio, et al., eds., Genji monogatari, Nihon koten bungaku zenshū (Tokyo: Shōgakkan, 1972), 3:204-5. Hereafter GM. Edward G. Seidensticker, trans., The Tale of Genji (New York: Knopf, 1976), 437. Hereafter TG.

30. TG, 438. See also GM, 3:204-5. 
ent means that helps in grasping the true meaning of the dharma. The good and bad characters in a novel, she claims, correspond to enlightenment and delusion respectively, and it is only through one that the true nature of the other can be apprehended. In this way fictional writing is not unlike scriptural writing. Both use expedient means that may appear to stand in contradiction to the ultimate truth but are in fact integral to our apprehension of it.

Another claim that Murasaki makes for writing is that human beings cannot help but be keen observers of the world around them, and, what is more, are driven by an urge to record all that they see and hear. This argument has striking resonances with the preface of Kokinshü (Collection of Ancient and Modern Poems, 905), the first imperial anthology, in which Ki no Tsurayuki wrote:

The poetry of Japan has its seed in the human heart [kokoro] and flourishes in a myriad leaves of words [koto no ha]. Human beings are creatures of many experiences, many deeds; it is in poetry that they give expression to the meditations of the heart in terms of what they see and hear. Hearing the warbler sing among the blossoms, or the frog in his fresh waters, is there any living being not given to song? Effortlessly poetry moves heaven and earth, stirs the feelings of the spirits invisible to the eye, softens relations between men and women, and calms the hearts of fierce warriors. ${ }^{31}$

It is not unlikely that the author of the Tale of Genji drew on the preface of Kokinshu, with which she must have been familiar, to assert for prose writing what Tsurayuki had claimed for Japanese poetry, namely, that the impetus to write about one's own observations and responses to the world was an irrepressible one. It should be pointed out that the case for poetry was always much stronger, because it claimed to be a natural and spontaneous expression of genuine feelings that arose in response to the natural world, as opposed to that inhabited by people.

The appearance of this exposition on the value of fictional writing in the Tale of Genji is significant. It suggests that the issue had already become a subject of some debate in Heian literary circles. At the same time, it is clear that Murasaki Shikibu does not display any serious concern about the validity of roman-

31. Ozawa Masao, ed., Kokin wakashü, Nihon koten bungaku zenshü, no. 7 (Tokyo: Shōgakkan, 1971), 49. 
tic fiction and, by extension, of her own work. Prince Genji's lecture on romances cannot be separated from the context in which it appears, namely, the curious relationship he has with the young girl Tamakatsura, who is at once his protégee and a potential object of his sexual desires. Genji's bantering tone with the young girl who, he claims, is gullible enough to be taken in by romantic nonsense, as well as his erudite explanation of the validity of romantic fiction, can be interpreted as Murasaki Shikibu's clever use of an ongoing debate to highlight the complex play of knowledge and power between the sexes.

To varying degrees the writers of native prose could not help but be aware of one of the major tropes of fiction at the time, that is, the conflict between creative writing and the Buddhist philosophy of renunciation. The Tale of Genji had been one of the earliest works to use this trope creatively as a plot contrivance. The work became the object of deep admiration not long after it was written. Perhaps for this very reason, in some of the writings that followed, the Tale of Genji itself became an object of the debate about fiction. A court lady whose name is unknown, but who is identified as being Takasue's daughter, wrote a diary called Sarashina nikki. The year of composition is a matter of some debate, but it is believed to have been written over a period of forty years, from the early to the mid-eleventh century. The main figure in this work displays a total absorption with the Tale of Genji and an obsessive longing for the world that it represents. This is accompanied by a sense of deep guilt about abandoning herself to romances and letting her thoughts be dominated by idle daydreams of lovers in the mold of the Shining Prince, Genji. After reading the Tale of Genji, she is visited in a dream by a priest in a yellow surplice who commands her to learn the fifth book of the Lotus Sutra immediately. She speaks with regret about having wasted her time reading fiction instead of employing it more fruitfully in the study of the sutras. ${ }^{32}$

In Sarashina nikki, the sense of unease and unhappiness experienced by the central character can be attributed to her confusion over fact and fiction-the irreconcilability of the world of romance and the reality of day-to-day life. In the text, it is through

32. Fujioka Tadaharu, et al., eds., Izumi Shikibu nikki, Murasaki Shikibu nikki, Sarashina nikki, Sanuki no Suke no nikki, Nihon koten bungaku zenshū, no. 18 (Tokyo: Shögakkan, 1971), 302. See also Ivan Morris, As I Crossed a Bridge of Dreams: Recollections of a Woman in Eleventh-Century Japan (New York: Dial, 1971), 47. 
Buddhist practice that the seductive power of monogatari is combated; the tension between these two conflicting claims is the source of the suffering of the female protagonist.

For all the misgivings about the validity of fictional writing in relation to the Buddhist injunctions, romances in the mode of the Tale of Genji continued to flourish in the late Heian and Kamakura periods. Of the large number of works that were written at this time, not many have survived to the present day. Occasional anxiety about immersion in frivolous pursuits notwithstanding, there is an absence in these works of any theorizing on the role and validity of literary writing. The relatively marginal position held by prose fiction may account for the lack of any sustained attempt to make it acceptable in Buddhist terms. Paradoxically, the exalted place assigned to poetry in medieval Japan meant that it demanded a more comprehensive justification of itself in relation to the highest spiritual ideals of the day, represented by Buddhism.

Two major prose genres that flourished in the late Heian and Kamakura periods, apart from the romances in the style of the Tale of Genji, were the gunki monogatari, or historical tales about war, and collections of legends and tales known as setsuwa.

The most important of all the gunki monogatari was Heike monogatari (Tales of the Heike, ca. 1184-1220), which recounted the struggle between the Minamoto and the Taira clans and the defeat of the Taira at the battle of Dannoura. Heike monogatari is a profoundly Buddhist work, as is evidenced by its concern for demonstrating the ultimate ephemerality of human endeavor and power. There are two interesting instances of the use of the term kyōgen kigo in this work. In one episode Kumagai Naozane, a Genji warrior, is forced to decapitate Atsumori, a young boy of no more than sixteen years of age who belongs to the Taira camp. After Naozane reluctantly performs this cruel act, he discovers Atsumori's flute and realizes that the flute that he had listened to appreciatively at dawn had been played by the lad that he has just killed. The sight of the flute and the memory of the music lead Naozane to take the tonsure and to renounce life as a warrior. It is at this juncture that the text alludes to Po Chü-i's statement: "It is indeed moving that the principle of wild words and fancy phrases finally becomes the cause for praising the Buddhist Vehicle." ${ }^{33}$

33. Takagi Ichinosuke, et al., eds., Heike monogatari, Nihon koten bungaku taikei, no. 32 (Tokyo: Iwanami Shoten, 1962), 1:222. 
In this instance music rather than literature is recognized as being equivalent to the pursuit of frivolous words, and at the same time it is praised as an expedient means that leads Naozane to abandon worldly life and become a monk. Clearly, the compilers of Heike monogatari were aware of the view that music, poetry, and other forms of art could become impediments to the attainment of enlightenment unless they served as expedient means to follow the Buddhist path. However, the compilers did not provide a defense of the work itself. Perhaps because gunki monogatari were not regarded as fiction but rather as literary representations of fact, they did not need to formulate a sustained justification of literary writing.

The historical tale entitled Ima kagami (Mirror of the Present), written in 1170 , takes up the issue of the validity of fictional writing by defending Murasaki Shikibu for writing the Tale of Genji. This defense was in response to a widespread belief that Murasaki was suffering in hell for the sins she had committed by fabricating a work of fiction. The narrator of Ima kagami claims that the Tale of Genji was a kind of expedient truth and suggests that Murasaki was no ordinary person but the bodhisattva Avalokitēśvara (Kannon) herself, who had appeared in human form to lead human beings to salvation. ${ }^{34}$

It is in this context that there emerged works such as Genji ippon kyō (Sutra in One Volume on Genji). This work was compiled by a monk named Ankyoin Chōken around the year 1166 and was written in Chinese in the form of a sutra. It was meant to be a prayer offered for the repose of the souls of Murasaki Shikibu and the readers of the Tale of Genji, who also were believed to be suffering in hell for spending their time on frivolous works of fiction. ${ }^{35}$

Another genre of prose writing that flourished in the Heian and Kamakura periods, besides romances and historical tales, was setsuwa. The term is a modern creation used to describe a diverse collection of tales and legends, both secular and Buddhist. The tales, despite their diversity, have certain features in common. Setsuwa are usually short anecdotes that center around a

34. See T.J. Harper, "A Twelfth-Century Critique of the Tale of Genji," Criticism in Translation 1.1 (September 1976).

35. Abe Akio, Oka Kazuo, and Yamagishi Tokuei, eds., Genji monogatari jo, Kokugo kokubungaku kenkyūshi taisei, no. 3 (Tokyo: Sanseido, 1960), 37 and 421 . 
particular event of an extraordinary nature presented to the readers as one that actually took place. Setsuwa differ from tsukurimono (fabricated, fictitious tales) such as the Tale of Genji in that they make a claim to veracity, to faithfully recording events that occurred in history.

The first extant collection of setsuwa is Nihon ryoiki or Nihonkoku genpō zen'aku ryōiki (Record of Miraculous Events in Japan Connected with the Immediate Retribution for Good and Punishment for Evil) by the monk Kyōkai (Keikai), compiled around the year 821 . In the preface, Kyōkai points out that he put together his collection in order to illustrate the workings of karma. It is only through an understanding of the laws of causality, he claims, that one can hope to reform evil and advance good. He focuses on exemplary events that have taken place in Japan in order that they may serve as models for his readers, who have thus far been brought up to take seriously only events in India and China. Kyökai's purpose is an avowedly didactic one. It seems likely that the original impetus for collecting setsuwa came from the need to proselytize for the Buddhist faith and that works such as Nihon ryoiki were used as prompt books by preachers in the course of their sermons.

It is believed that more than one hundred collections of setsuwa were compiled between the year 821 , when Nihon ryoiki was put together, and 1331, the end of the Kamakura period. Of these, about forty-five are still extant. ${ }^{36}$ Among the most wellknown of these collections is Konjaku monogatari shü (Tales of Times Now Past), compiled in the late Heian period, which included setsuwa based on legends and tales from India, China, and Japan as well as on more contemporary events. Two-thirds of the stories in this collection are Buddhist, while the rest are of a secular nature.

Uji shüi monogatari (Tales of Uji, ca. 1215) is a collection that draws freely on stories from the scriptures, from Chinese and Indian tales, from popular folklore, and from other setsuwa collections to create a diverse world that includes courtiers, provincial warriors, monks, and peasants. Often in these stories religious morality gives way to the more worldly virtues of good sense, fortitude, and cunning.

36. For a discussion on the classification of setsuwa collections see Michael Kelsey, Konjaku Monogatari-shü (Boston: Twayne, 1982), 3444. 
In the medieval worldview, the site of aesthetic pleasure was often located on Buddhist terrain. Buddhist themes and legends had captured the popular imagination, and audiences enjoyed a story that taught a moral and did so in an entertaining manner. Both Konjaku monogatari shū and $U_{j j i}$ shüi monogatari defy categorization as purely edification or entertainment. They sought to be both.

Senjūshō (Collection of Selected Tales), attributed to Saigyō (1118-90), and Kamo no Chōmei's Hosshinshū were Buddhist setsuwa collections that did not have direct connections with preaching or sermons. The recluses who wrote such setsuwa extolled ascetics and recluses who led individual and sometimes eccentric lives in order to pursue the Buddhist path and who made poetry and music an important part of their Buddhist practices. These writers sought to establish a karmic link with the ideal figures that appear in their texts in the hope that they would aid their own salvation. I shall return to a discussion of these works later.

What is striking, for the purposes of my argument, is the fact that by the Kamakura period there was an attempt made to justify the writing of setsuwa and that this justification was often made in Buddhist terms. Thus collections as diverse as Jikkinshō (Miscellany of Ten Teachings, 1252), on the one hand, which sought to promote the values and ideals of courtly life, and Shasekishū (Collection of Sand and Pebbles, 1283) by Mujū Ichien (12261312), on the other, which sought to preach the Buddha's dharma to ordinary people, both claimed that while these works were no more than wild words and fancy phrases, they could, nonetheless, be used as expedient means to promote Buddhism.

Jikkinshō is a collection of short tales based on incidents in the lives of famous men in Chinese and Japanese history. The authorship of the work is uncertain, although it has been attributed by some scholars to the lay priest Rokuhara Jirōzaemon. The aim of the work, as stated in the preface, is explicitly didactic. It sets out to instruct youth on the ten principles of conduct and attempts to inculcate the values and artistic sensibilities of the aristocracy in young men.

The preface of Jikkinshō is clearly written from a Buddhist standpoint. It is hard to say whether this is due to the supposedly priestly vocation of its author or because it was from within the Buddhist position that a defense of such writing was traditionally made. The author points out that human beings, irrespective of 
whether they are of high or low birth, have very different dispositions. These dispositions give rise to behavior that brings great merit to those who are noble and great loss to those who are foolish. He claims that by writing about events that he has himself witnessed and about those from the past of which he has heard, he hopes to deter his readers from following the evil path and to encourage them to accept the path of goodness. He assures his readers that he has not decorated his writings with false words (munashiki kotoba) and that he has merely put together examples of events that have really taken place.

This is followed by a standard declaration of modesty, in which he deplores his own lack of artistic accomplishment and expresses his embarrassment at the scorn with which his writing is likely to be met. He admits that although he is well aware of his shortcomings, he is driven by an irresistible desire to write:

\begin{abstract}
When I contemplate the origins of this desire to seek pleasure through writing, I see that it is not possible to escape from the karma of words. This goes against the counsel of the noble and virtuous and appears to ignore the very teachings of the Buddha. But when one reflects calmly on the principle that all the dharmas have the characteristics of the ultimate reality [shōbo jissō], then even the wanton sport of wild words and fancy phrases [kyōgen kigo] can be transformed into the condition for praising the Buddhist Vehicle. All the more so, if through one's writings, one despises arrogance and promotes righteousness, how can one's work fail to be in accord with Buddhist principles? Why then should I have any hesitation? ${ }^{37}$
\end{abstract}

The compiler of the Jikkinsho shows familiarity with the Tendai doctrine of nonduality, which stressed that all elements that manifest themselves are in no way distinct from the ultimate reality ( $s h \bar{o} b \bar{o} j i s s \bar{o})$. Referring to this, he suggests that there is no real distinction between secular and sacred writing.

\title{
Nonduality, KYōGEN KIGo, AND HōBeN
}

While at the abstract theoretical level the notion of duality was one that could be rejected, at the practical level of popularizing the faith there appears to have been a certain unease about ac-

37. Izumi Motohiro, ed., Jikkinshō, Koten bunkō 352 (Tokyo: Koten Bunkō, 1976), 9-1 1. See also John Brownlee, "Jikkinshō: A Miscellany of Ten Maxims," Monumenta Nipponica 29.2 (summer 1974): 121-63. 
cepting the implications of such a position. Thus as the great thirteenth-century proselytizer, Ippen Shönin, put it:

It has been explained that ignorance is identical to enlightenment [bonnō soku bodai] and that samsara is nirvana [shöji soku nehan]. Although I should teach this to people, I feel that it is not in accordance with the potential of people at this time. This is because they will surely revert back to their original attachment to worldly desires, and thus this teaching will only bring them harm. ${ }^{38}$

What Ippen is suggesting here is that for the notion of nonduality to be accepted at the practical level, it was necessary to introduce the idea of expedient means. As the great Mādyamika philosopher Nāgārjuna put it, "The highest truth cannot be taught without recourse to conventional language (vyavahära)." 39 In this way even the Buddha's teachings fall into the category of relative truths as they attempt to verbalize what is ultimately inexpressible. But these relative truths are a valid and necessary means, the very basis for realizing the absolute.

The notion of expedient means came to play a vital role in Mahäyāna Buddhism and is one of the central themes of the Lotus Sutra. This sutra expounds the idea that the truth is one but the means to attain it are varied. This is because human beings are different in character, temperament, and inclination. It is therefore necessary to use a variety of expedient means to lead people to enlightenment. To explain this doctrine, the Lotus Sutra uses numerous parables, the most famous of which is the parable of the rich man who saves his children from a burning house. He does so by promising them all kinds of carts-bullock carts, goat carts, and antelope carts-that he knows they are attached to. After luring them out of the house, he gives each of them a splendid gold-decorated ox-drawn carriage instead. ${ }^{40}$ At one level the old man lied to his children, but his lie was justified because it was an expedient means to lead them out of the burning house. In this parable the father is the Buddha, who attempts to lead human beings out of their world of delusion and attachment. The

38. Ōhashi Shunnō, ed., Ippen shōnin gokuraku, in Hōnen, Ippen, Nihon shisō taikei, no. 10 (Tokyo: Iwanami Shoten, 1971), 322.

39. Bimal K. Matilal, "A Critique of the Madhyamika Position," in The Problem of Two Truths in Buddhism and Vedanta (Dordrecht, Holland: D. Reidel, 1973), 59.

40. See Hurvitz, Scripture of the Lotus Blossom, 58-64. 
splendid carriage he offers is the Greater Vehicle, or the Mahāyāna teachings. However the Lesser Vehicles, or the Hinayanna teachings, are not to be rejected completely. They must be relied upon in order to lead ordinary human beings, who are still attached to worldly things, to the ultimate truth of Mahāyāna. The absolute is conceptually indeterminable, and hence it is not only possible but inevitable that we employ a variety of allegories, metaphors, and parables as a means to suggest it.

In dealing with the question of artistic practice and its relationship to Buddhism, the notion of expedient means came to play a vital role and found its most popular expression in the term kyōgen kigo. There was another reason why this term gained especially great currency in the Kamakura period. It was at this time that the theory of mappo (degeneration of the dharma, or law) was taken up seriously by Buddhists and came to be widely accepted among the laity. ${ }^{41}$ It was believed that in the age of mappō, the teachings of the Buddha would remain only in form and that both practice and enlightenment would be ignored. In an age in which higher methods of reaching nirvana were inefficacious, "wild words and fancy phrases" were a particularly necessary and effective means for conveying the true meaning of the dharma. It is to the concept of mappo that Ippen alludes when he claims that the teachings of nonduality are "not in accordance with the potential of people at this time."

The notion of mappo first developed in India in response to the fear that the true dharma was passing away. This had much to do with the fact that after the death of the historical Buddha, uncertainty existed regarding the true teachings of the founder, due to the emergence of sectarian differences of opinion. The invasion of northern India in the sixth century A.D. by the Huns, who were noted for their animosity toward Buddhism, made the end of the dharma seem even more imminent.

Although the concept of mappō arrived in Japan as early as the Nara period, it was not taken up seriously until the late Heian period. In China Hui-Ssu (515-77) of the T'ien-t'ai sect had assigned dates to distinguish the three periods of Buddha's law:

True teachings (shōbō). 500 years. This was the period after the death of the Buddha when the teaching, practice, and attainment of Buddhist doctrine was possible.

41. See Yamada Ryūjō, "Mappō shisō ni tsuite," Indogaku bukkyōgaku kenkyü 4.2 (March 1956): 54-63. 
Simulated teachings $(z \bar{o} b \bar{b}) .1,000$ years. In this period only the teaching and practice would remain.

Decline of the law (mappō). 10,000 years. Only the empty teachings would remain, while both practice and enlightenment would be ignored.

By the Japanese calculation, the first year of mappō was to commence in 1055. The disasters and upheavals of the twelfth century could thus be interpreted as tangible proof of the arrival of the period of the decline of the law. In 1177 a great fire ravaged the capital; in 1180 a hurricane destroyed a large portion of the city; and that same year Taira Kiyomori made a fruitless attempt to shift the capital, dislodging thousands from their homes. Famines raged in the years 1134 and 1181. In this context the increasing popularity of the term kyogen kigo can be understood.

Mujū Ichien attempts a justification of Shasekishū on the basis of the notion of nonduality and its practical realization through the concept of expedient means. In the preface, Mujū states the purpose behind his compilation of tales:

Coarse words and refined expressions both proceed from the first principle, nor are the everyday affairs of life at variance with the true reality [jissō]. And so through the wanton sport of wild words and fancy phrases [kyogen kigol I wish to bring people into the marvelous Way of the Buddha's teaching; and with unpretentious examples taken from common ordinary affairs of life I should like to illustrate the profound significance of this splendid doctrine.-I have recorded incidents just as they have come to mind, without selecting the good from the badThere is not just one method for entering the Way, the causes and conditions for enlightenment being many. Once a person understands their general significance, he will see that the purport of the various teachings does not vary-Those who search for gold extract it from sand; those who take pleasure in jewels gather pebbles and polish them. So I have called this book the Collection of Sand and Pebbles. ${ }^{42}$

Writers of Buddhist setsuwa such as Mujū Ichien sought to convey the Buddhist teachings to ordinary people. No matter

42. Watanabe Tsunaya, ed., Shasekishū, Nihon koten bungaku taikei, no. 85 (Tokyo: Iwanami Shoten, 1966), 57. See Robert E. Morrell, Sand and Pebbles (Shasekishū): The Tales of Mujū Ichien, A Voice for Pluralism in Kamakura Buddhism (Albany: State University of New York Press, 1985), 71-72. 
how entertainingly they recounted their tales, these writers were at pains to explain that their work had no intrinsic value and that the tales were merely expedient means through which the Buddhist doctrine could be taught. It seems likely that for writers of setsuwa, assigning a clear didactic purpose to their work was essential if they wished to tell a good story. Buddhist priests, who were the major compilers of setsuwa, displayed a deep ambivalence toward literary activity-they were convinced that it was sinful, but at the same time it was an activity they wished to harness to the Buddhist cause.

\section{Japanese Poetry (WaKa) and the Ideal of $M i c h I$}

It was in the realm of Japanese poetry (waka) that the relationship between Buddhism, on the one hand, and literary writing, on the other, came to be debated with great urgency.

The compilation of Kokinshü was a significant development in Japanese poetry and one that signaled a major break with the past. For the first time an official anthology of waka rather than shih (a Chinese verse form) had been promoted, and the monopoly of the shih was challenged. There had not been any major anthology of Japanese poetry since the compilation of Man'yōshü in the mid-eighth century. With Kokinshü, Japanese poets were able to draw upon the themes and styles sanctioned by the shih of the Six Dynasties and the T'ang periods and write poetry in the native idiom. Unlike the poetry in Man'yõshü, which was written in man'yögana (a system of recording Japanese using Chinese characters), the new poetry had at its disposal hiragana, a far less cumbersome syllabary script. This allowed men and, more particularly, women in the Heian court to express themselves more freely in their own language.

In the Heian period, waka was regarded as the ideal mode of communication between lovers. It was central to the aesthetic ideal of füryu (in Chinese feng liu) that best exemplified the lives of the aristocracy. As Konishi Jin'ichi has pointed out, the concept of füryu was essentially a hedonistic one of Taoist origins, which placed great emphasis on the enjoyment of amorous pursuits, drinking wine, composing poetry, and playing music. ${ }^{43}$ In

43. Konishi Jin'ichi, "Füryū: An Ideal of Japanese Esthetic Life," Orient/ West 7.7 (July 1962): 11-16. See also Phillip Harries, "Füryü, a Concept of Elegance in Pre-Modern Literature," in Europe Interprets Japan, edited by Gordon Daniels (Kent: Paul Norbury, 1984). 
Japan the term first came to be used in Man'yōshū and was frequently rendered by the Japanese word miyabi, which means essentially "of the court" or "courtly," as opposed to hinabi or inakabi, meaning "boorish" or "rustic." This suggests that by the Nara period the term füryu was already associated with the qualities that marked courtly life, namely refinement, the art of love, poetry, music, and other artistic pursuits.

The two major topics of Kokinshü poetry were love and the seasons. Both in the progression of the changing seasons and in the pattern of love affairs-the first glimpses of the beloved, the consummation of the affair, its final dissolution, and the sadness that follows-the theme of the fundamental transience of worldly existence played an important part. But this perception of evanescence, even while it may have been informed by the Buddhist view of the world, did not lead to the creation of a separate category of poems devoted to Buddhist themes, as was to be the case with later poetic anthologies, beginning with the compilation of Goshui wakashü (Later Collection of Gleanings) in 1086, in which was included a group of poems under the heading of Shakkyōka (Poems on the Teachings of the Buddha Sākyamuni). ${ }^{44}$ For example, in the section entitled "Miscellaneous Poems" in Kokinshu, there are some poems that deal directly with Buddhist themes, such as renouncing worldly life and living in seclusion in the mountains, away from the secular world. However, like the poetry anthology Shüi wakashū (Collection of Gleanings), completed sometime between 1005 and 1011, which also included some poems with Buddhist themes, Kokinshü did not have a separate category for such poems. Nor did Kokinshü attempt any justification or valorization of waka in Buddhist terms.

This is not to suggest that in the Heian period there was no attempt at theorizing about the relationship between poetry and Buddhism. While poems that dealt with ideas and themes that were Buddhist in nature were simply treated as waka, there occurred at the same time a more explicit articulation of the validity and role of poetry. A fascinating work in this regard is Hosshin wakash $\bar{u}$ by the imperial princess Senshi (964-1035). This collection of poetry, composed in all probability for a small audience comprising Senshi's close circle of

44. For a translation and critical commentary on the shakkyōka in Goshüishū, see Robert E. Morrell, "The Buddhist Poetry in the Goshūishū," Monumenta Nipponica 28.1 (spring 1973): 87-100. 
attendants, is regarded as the first collection of shakkyōka composed by a single poet. ${ }^{45}$

In the preface to her work, Senshi defends Japanese poetry as a Buddhist practice. In order to justify this claim she argues that even in the Lotus Sutra the Buddha Sākyamuni sang the praises of the Tathāgatas in verse. It is for this reason, she claims, that "we know that the composition of verses is very meritorious and that it is a form of Buddhist worship." 46 In an interesting foreshadowing of the Buddhist priest Mujü Ichien's defense of Japanese poetry, which we discuss later in this chapter, Senshi makes a special case for the composition of Japanese poetry. She writes,

Sanskrit is an Indian language, and India lies far across the desert sands; kanji are a Chinese invention, and the customs of China are very different from ours. I was born in Japan, and received the body of a woman: I cannot imitate the manners of those foreign places, and my sensibilities are wholly those of my homeland. I have studied the thirty-one syllable poetry invented by Susa-no-o, and have nurtured this tradition. ${ }^{47}$

Senshi sees no reason why she should give up Japanese poetry in order to engage in Buddhist meditation. She chooses rather to make poetry her religious practice and expresses the hope that through her compositions both she and those who read her work will experience religious awakening (hosshin). In arguing thus, Senshi anticipates many of the debates that became de rigueur among waka theorists of the Kamakura period. As Edward Kamens puts it, "She may still be recognized as one of the important antecedents of those who argued that a capacity for composing waka is identical with the capacity for attaining enlightenment, that the 'way of Japanese poetry' and the 'way of the Buddha' are one and the same." 48

45. My discussion of the Hosshin wakashü is based upon Edward Kamens's excellent study of this text in The Buddhist Poetry of the Great Kamo Priestess: Daisaiin Senshi and "Hosshin Wakashū," Michigan Monograph Series in Japanese Studies, no. 5 (Ann Arbor: Center for Japanese Studies, The University of Michigan, 1990).

46. Ibid., 66.

47. Ibid.

48. Ibid., 74. 
By the twelfth century, the composition of waka in particular became the most highly revered form of literary activity and one that was pursued with a single-minded dedication. At the same time, Buddhist ideals came to have a deeper meaning for the aristocracy, who now more seriously than ever before followed Buddhist practices. The growing interpenetration of the literary and Buddhist traditions resulted in the emergence of many more poets who saw Buddhism as integral to their poetic practice, as well as priests who sought to include poetry among the prescribed religious practices. The increased importance of these two realms and their interaction with one another gave rise to new formulations regarding the exact nature of the place of poetry in the life of a Buddhist. While kyoggen kigo continued to be one important if rather formulaic response to this question, new assertions emerged that stressed the identity of poetry and the scriptural writings.

Several factors contributed to this radical transformation of poetry into an artistic practice par excellence that could make claims to being not only on a par with but, at times, even identical with Buddhist writings. Perhaps the most crucial of these was the emergence of the ideal of michi (the way) in the twelfth century, which was fundamental in shaping new perceptions about the connections between poetry and Buddhism. ${ }^{49}$

Central to the ideal of michi was the belief that total dedication to a particular pursuit would lead to the intuitive understanding of a universal truth. This was true as much of the most trivial and insignificant pursuits as it was of the more respected disciplines. This universal essence or truth that could be penetrated through the dedicated pursuit of any discipline, no matter how insignificant, was seen as being none other than the truth inherent in the Buddhist dharma-an indication of the profound influence of Tendai Buddhism on the way in which the ideal of michi came to be formulated.

The Tendai school sets forth the notion of the threefold truth, namely the truth of void $(k \bar{u})$, the truth of temporariness (ke), and the truth of mean $(c h \bar{u})$. These three truths penetrate

49. For a detailed discussion of the concept of michi, see Konishi Jin'ichi's fine study, Michi: Chūsei no rinen, Nihon no koten, no. 3 (Tokyo: Kōdansha, 1975). See also Konishi Jin'ichi, "Michi and Medieval Writing," in Principles of Classical Japanese Literature, edited by Earl Miner (Princeton: Princeton University Press, 1985). 
one another and are found perfectly harmonized and united. "A thing is void but is also temporarily existent. It is temporary because it is void, and the fact that everything is void and at the same time temporary is the middle truth." 50 That is to say, all elements or dharmas have only a nominal existence. They come into being through chance causal combinations but are ever changing. They do not have a permanent existence but can be granted a temporary existence. The true state of things can be seen only through phenomena, which are always in a state of flux. The phenomena themselves are identical with the true state of things. This leads to the formulation that the world of phenomena and the world of enlightenment are identical (shoji soku nehan). Once the absolute and the phenomenal are not treated as separate entities and we accept that the absolute is never totally transcendent from the present world, then we come to the position that the phenomenal world (samsara, shōji) and the world of enlightenment (nirvana, nehan) are essentially one. There is no difference in locus between the world of ignorance and the world of enlightenment. This is the basis of the Buddhist maxim that found popular expression in Japan in the phrase bonno soku bodai (ignorance is identical with enlightenment). This also allowed for the formulation of the notion that the way of poetry and the way of Buddha were essentially inseparable.

The position that all dharmas are interdependent and permeate one another, thus resulting in the ultimate unity of the whole universe, was the basis of the Tendai doctrine of the Ten Worlds Concomitant (jikkai goggu). ${ }^{51}$ Another extension of this logic was the doctrine of endonkai, the perfect and immediate precept that was first advanced by Saichō (Dengyō Daishi, 767-822), the

50. Takakusu Junjirō, The Essentials of Buddhist Philosophy (Honolulu: University of Hawaii, 1947), 136.

51 . The Ten Worlds are the worlds of hell, of the hungry ghosts, of animals, of asuras, of humans, of celestial beings, of arhats, of the selfenlightened, of the bodhisattvas, and of the Buddhas. Each of the ten worlds was seen as having an independent existence: an inhabitant of the human world, for example, might be reborn after death in the world of hell or the world of celestial beings, depending on his past karma. Thus the human world was separate from the other nine worlds. But while recognizing the mutual exclusivity of the ten worlds, Tendai teaching also conceived of each world as simultaneously containing within itself the other nine worlds. Thus one world was the ten worlds and the ten worlds were the hundred worlds. 
founder of Tendai Buddhism in Japan. He argued that if one fulfills one precept, then all the rest will be contained in it. This of course is a radical departure from Hinayāna Buddhist practice, which demands that all the precepts set out for the priests-two hundred and fifty for monks and three hundred and forty-eight for nuns-be strictly observed. Mahãyāna Buddhism also requires that all the major precepts be observed. If the logic of Saichō's formulation-if one fulfills one single precept perfectly, all the rest of the precepts will be contained within it-is extended further, then even songs and poems that emanate from secular activity share certain features with the Buddha's teachings. It is possible, then, to claim that by penetrating the innermost meaning of an art, one would encompass within that art the innermost meaning of all other paths (michi), even that of the way of the Buddha (hotoke no michi). Thus the belief that the pursuit of poetry as a michi constituted a Buddhist practice was arrived at by drawing upon Tendai philosophical discourse.

It was Japanese poetry that emerged above every other artistic practice as the most prestigious of all michi, and one that was cultivated by the aristocracy of the Kamakura period with total commitment. The pursuit of poetry as a serious vocation was a major departure from the role that poetry had played in the lives of the Heian courtiers. The compilation of the Kokinshü in the Heian period had marked the formal recognition of Japanese poetry as a highly valued artistic pursuit. But for all that, while Japanese poetry gained a new respectability and prestige, the high aristocracy still looked on poets such as Ki no Tsurayuki as little more than waka artisans, who could be commissioned to produce poems for the decoration of folding screens and who were therefore expected to comply with the demands of their patrons. The changed status of waka in the Kamakura period is clearly reflected in the way the term suki came to be used. Suki now signified the single-minded pursuit of one artistic practice, a devotion to a michi. Suki and michi were now inextricably interrelated. The process whereby this occurred is one I explore at length in chapter three.

By the twelfth century, poets such as Minamoto no Shunrai (d. 1129) and Fujiwara no Mototoshi (1055-1138), neither of whom held high rank, became leading figures in waka circles and were invited to poetry gatherings held by high-ranking aristocrats, who themselves began to take a much more active part in the composition of poetry. By the end of the twelfth century, waka schools 
came to be established. The Rokujō branch of the Fujiwara was shaped into a school of waka by Fujiwara no Akisuke (1090-1155) and his sons Kiyosuke (1104-77), Shigeie (1161-1207), and Suetsune (1131-1221). Fujiwara no Shunzei (1114-1204), who became a pupil of Fujiwara no Mototoshi, formed the Mikohidari school, which became the most prestigious of all waka schools.

Clearly, this major transformation of Japanese poetry into a serious vocation, a michi, had a great deal to do with a more serious engagement with Buddhism by the court aristocracy in the twelfth century. It also had a great deal to do with major political and social changes that deeply affected the position of the courtiers, forcing them to define their own cultural world in radically new ways. ${ }^{52}$

The tenth and eleventh centuries in Japan had seen the development of a form of government in which full sovereign power rested on a virtually hereditary basis, devolving on members of one clan, the Fujiwara. The Fujiwara came to acquire enormous power by controlling the imperial family through a complex system of marriage alliances, by getting themselves appointed as regents to emperors, and through their acquisition of important manorial estates that brought them great wealth.

In the late eleventh century, certain elements of the ruling class reacted against the exclusive power wielded by the Fujiwara family, a reaction that led to a system of rule by the retired emperor (insei). The retired emperors ostensibly left political life by taking the tonsure, but in actual fact worked toward the creation of a separate power structure in which an abdicated emperor held power comparable to that of the reigning emperor and the Fujiwara government. This kind of two-tier system was of course fraught with problems, and its existence meant considerable tensions. The conflict came to a head when the retired emperor Go-Shirakawa, pretending to act as guardian to the emperor, attempted a coup d'état that resulted in a series of civil wars-the Hogen and Heiji insurrections. For the first time the aristocracy had been forced to turn to the provincial warrior classes to help it consoli-

52. For detailed studies of bakufu rule see Jeffrey P. Mass, Warrior Government in Early Medieval Japan (New Haven: Yale University Press, 1974); George Sansom, A History of Japan to 1334, vol. 1 of A History of Japan (Stanford: Stanford University Press, 1958); and Shinoda Minoru, The Founding of the Kamakura Shogunate (New York: Columbia University Press, 1960). 
date its own position. This resulted in a shift in the locus of power, which culminated in the establishment of a military dictatorship in Kamakura, the Kamakura bakufu.

However, the nobility was not totally supplanted by the new military government. The leader of the bakufu government, Minamoto no Yoritomo (1147-99), continued to acknowledge the authority of the emperor by giving him the power to confirm Yoritomo's position and rights. Thus it was the court that gave Yoritomo his title of shogun. The relationship between Kyoto and Kamakura in the thirteenth century was one of mutual dependence, in which the aristocracy sought to take maximum advantage of the Kamakura bakufu's reliance on the court for the maintenance of its authority and prestige. The central concern of the absentee, land-owning nobility was with securing, through the influence of those in power, the revenues from their manorial estates. However, as more and more land came to be passed on to the provincial gentry, the middle- and lower-ranking courtiers (zuryo) lost control of their estates, and many of them were left with only their salaries to support them. This change in their economic status brought with it a decline in the opulent and elegant lifestyle cultivated by the Heian aristocracy. The ideal of füryu could not be maintained without financial power. As we have seen, the ideal of michi replaced füry $\bar{u}$, which had flourished in more prosperous times.

A nobility that had once possessed considerable social and political power, and that had taken its pursuit of refined aesthetic pursuits for granted, now began to grow more sharply aware and self-conscious of its culture and sought to carve out for itself an exclusive domain in the areas of scholarship, literature, and the arts in general. The defense of their culture proved to be one effective way in which the aristocrats maintained their superiority over the emergent warrior clans who had divested them of real power. This new awareness of their domain of power, namely culture, contributed in no small measure to the emergence of the ideal of michi in the Kamakura period. Artistic practices were cultivated with the utmost seriousness; rules of precedent had to be learned and clearly cited; and knowledge of a particular practice could only be passed down from teacher to pupil. A particular michi thus became the monopoly of the chosen few. The provincial warriors, for their part, acknowledged the cultural superiority of the Kyoto court and began to follow the aristocratic lead in matters of taste and fashion. The shogun Minamoto no Sanetomo 
(1192-1219), for example, was an avid student of poetry and studied it under the tutelage of the court poet Fujiwara no Teika. ${ }^{53}$

The development of the ideal of michi and the seriousness with which poetry and other artistic practices came to be pursued had important consequences for the ways in which Buddhist priests and practitioners of waka interpreted literary activity and related it to the practice of Buddhism. It is in this context that there emerged a more elaborately argued defense of these practices on religious grounds.

\section{Waka as Religious Practice}

By the twelfth century, poetry had become a michi, and it guaranteed fame to those who received instruction from an acknowledged master and who then achieved excellence through a singleminded dedication to their art. Poets such as Fujiwara no Shunzei and his son, Fujiwara no Teika, were first and foremost court poets, and they depended heavily on imperial patronage for the promotion of their vocation. They came to dominate the world of poetry not only as composers but also as theoreticians who defined and set the norms for poetic style and content.

Their devotion to poetry as a michi was, however, not clearly separated from their deep immersion in Buddhist values and practices. Even though poetry was their vocation and that which defined them socially, it was in Buddhist terms that they sought to define poetic goals and practices and to work out a satisfactory resolution to the question of the place of their art in relation to Buddhism. In his poetic treatise Korai füteishö (Notes on Poetic Style throughout the Ages, 1201), for example, Shunzei poses the problem of distinguishing between good and bad poetry. He begins by elucidating the various levels at which the composition of poetry is comparable to Buddhist practice:

The Tendai text Mo-ho chih-kuan ${ }^{54}$ [Makashikan] begins with the following words by Kuan-ting, "The clarity and tranquillity of great concentration and insight [shikan] has no peer-in the past or the present." From the mo-

53. Robert H. Brower, "Fujiwara Teika's Maigetsushō," Monumenta Nipponica 40. 4 (winter 1985): 399-425.

54. Mo-ho chih-kuan (Makashikan) was a Tendai manual on meditation by Chih-i (538-97), recorded by his disciple Kuan-ting. See Sekiguchi Shindai, ed., Makashikan (Tokyo: Iwanami Shoten, 1966). 
ment we hear this we are struck with awe and admiration by its infinite profundity, and its innermost significance is brought home to us. In the same way, understanding the good and bad in poetry, and penetrating its deep significance, is hard to express in words. However, by likening poetry to the practice of great concentration and insight, we can come to an intuitive understanding of it. In the text of the Mo-ho chih-kuan too, what is clarified first and foremost are the stages by which the Buddha's dharma was transmitted. It explains to people the way in which the dharma came to be handed down. The great enlightened one, Sãkyamuni, transmitted the dharma to Kásyapa, who in turn passed it on to Ānanda. In this way it was transmitted from master to disciple down through twenty-three persons. When we hear of the way in which the dharma was transmitted, we are filled with reverence. In the same way, we get a sense of the profundity of Japanese poetry when we consider that it has been handed down to us from ancient times, in the form of a series of anthologies, beginning with Man'yōshü and continuing through Kokinshū, Gosenshū, Shüishū, and so on. However, in one case we are talking about the profound truth of the dharma, transmitted by the Buddha Sākyamuni, "the gold-mouthed one." In the case of Japanese poetry, on the other hand, we have the verbal sport of "wild words and fancy phrases" [kyōgen kigo]. However, in poetry something of the profound significance of things does emerge, and through this we are brought to an understanding of the way of the Buddha. Furthermore, it is because enlightenment and delusion are identical that in the Lotus Sutra it says, "If he preaches secular classics . . occupations that sustain life, and things of this sort, he shall in every case do so in accord with the Fine Dharma." ${ }^{55}$ The Samantabhadra Bodhisattva Sutra ${ }^{56}$ explains, "Of what person can we say that this is bad and that is good? Neither vice nor virtue has an owner. Our mind possesses of its own accord the character of the void." This being the case, I have likened the profound way of poetry to the three aspects of truth, namely, the void, the provisional, and the mean. ${ }^{57}$

55. Hurvitz, Scripture of the Lotus Blossom, 276.

56. The Tendai sect regards the Fugen kangyo or Samantabhadra Bodhisattva Sutra as the conclusion to the Lotus Sutra. Together with the Muryōgikyō (Sutra of Innumerable Meanings), which is seen as the preface, the three sutras are together called the Hokke sanbukyō (Threefold Lotus Sutra).

57. Hisamatsu Sen'ichi, ed., Korai füteishō, in Karonshū, vol. 1, Chūsei no bungaku (Tokyo: Miai Shoten, 1971), 119-20. 
In this passage Shunzei uses Makashikan (The Great Cessation and Insight) to forge an aesthetics that is based on the Tendai doctrine of nonduality and more specifically on the practice of concentration and insight (shikan). Shikan is the Japanese rendering of two Sanskrit terms, samatha (shi) and vipasyana (kan). Samatha is the cessation of all perceptions and cognition of ordinary experience and thus the attainment of a state of mind that is calm and tranquil. Vipasyana is the contemplation of any object that forms part of our ordinary perception. As William LaFleur puts it,

The contemplator, in accord with the fundamental impermanence of all things (himself included), regards them without obstruction (muge), that is, without the sort of discriminating mind that would seek to arrange phenomena into hierarchies of relative importance and select out some-primarily himself or some part of himself-as deserving of exemption from the rule of impartial impermanence (mujō). ${ }^{58}$

The interdependence of all phenomena and the fact that they are in a state of constant flux mean that there are no "essences" that can be penetrated. The phenomenal and the Ultimate are in the last analysis identical. The doctrine of nonduality enables Shunzei to demonstrate that any clear distinction between "sacred" and "secular" texts is untenable within the Buddhist doctrine itself. This being the case, the composition of poetry has to be regarded as a Buddhist activity. The world of nature and human emotions are for him both rightfully the subject of poetry. This is because, as Konishi points out, there is an absolute rejection of existence conceived of as a confrontational relationship between the perceiver and the perceived. The contemplator is ultimately not distinct from the contemplated object. The phenomena presented in his poems are observed in such a way that both their coming into being and their dissolution are observed with calm and tranquillity. It is the practice of shikan that lies at the center of Shunzei's poetic practice. ${ }^{59}$

Among the poems that Shunzei left behind, there are many like the twenty-eight poems based on the chapters of the Lotus

58. LaFleur, Karma of Words, 88.

59. Konishi Jin'ichi, "Shunzei no yūgenfü to shikan," Bungaku 20.2 (February 1952): $111-12$. 
Sutra, the Nijūhapponka, which were avowedly religious in nature. However, Shunzei's poetry can be regarded as profoundly Buddhist not only or even primarily because of his conscious espousal of religious themes, but because of the presence in it of a fundamentally Buddhist worldview. It is also worth noting, however, that Shunzei paid the utmost regard to rules of poetic precedent, and it was within the confines of an established artistic medium that he sought to imbue his own poems with a greater richness and depth. This fact is of some importance in the present discussion because it allows us to make a distinction between poets who were first and foremost dedicated to their art and whose main concern was with the composition of good poetry and priests who had a high regard for poetry but sought primarily to use it to further religious ends.

\section{Priests as the Defenders of Japanese Poetry}

Mujū Ichien presents an elaborate defense of waka writing as a religious practice - a reflection of the high regard with which this artistic practice came to be held by all members of the literati. His position, however, departs in important ways from that of Shunzei. He draws a clear distinction between poetry that concerns itself with themes of love and that is steeped in attachment, in other words, poetry as kyogen kigo, and poetry that serves as a means to understanding the Buddhist teachings. Muju writes:

As a rule, waka is included among all that constitutes kyōgen kigo because calling itself love poetry: it is drawn toward human emotions; it is steeped in themes of love that cannot be depended upon in any way; and it adorns itself with empty words. But if by putting forward the Buddhist teachings and bearing the spirit of the transience of all things waka weakens one's ties with worldly things and one's thoughts of the mundane, if by looking at the leaves falling in the wind one forgets one's attachment to fame and wealth and comprehends the worthlessness of worldly existence, and if by reciting poems on the snow and the moon one's heart is enlightened into comprehending the unblemished ultimate truth, then waka can serve as a go-between for entering the Buddhist path and as a means to understanding the Buddhist teachings. It is for this reason that the men of old who practiced the Buddhist dharma in no way cast aside the way of poetry. ${ }^{60}$

60. Watanabe Tsunaya, Shasekishū, 220-21 (translation my own). 
For Mujū, Japanese poetry was important because he saw it as a particularly efficacious means of understanding the Buddhist dharma. This belief in the special power of waka was derived from theoretical formulations within Tendai and Shingon Buddhism. It was further bolstered by the prevailing view that the Shinto gods had expressed themselves through Japanese poetry.

From as early as the Nara period, Buddhism gained ascendancy in Japan not by standing in opposition to Shinto, Confucian, and Taoist beliefs but by attempting to integrate the varied philosophical traditions within a Buddhist perspective. One way in which Shinto came to be assimilated within the Buddhist framework was through the scheme of honji suijaku (true naturetrace manifestation), whereby the Shinto deities were regarded as local manifestations of the Buddhas or bodhisattvas, left behind in Japan especially to save the Japanese. This view had implications that were not overlooked by advocates of poetry. The first poem in the native language was said to have been composed by the god Susa-no-o-mikoto and was recorded in Kojiki. If the gods were manifestations of the Buddha and composed Japanese poetry, it could be argued that waka constituted the words of the Buddha himself. In Shasekishu, using the theory of honji suijaku, this is in fact what Mujū argues:

The gods of Japan are manifest traces, the unexcelled transformation bodies [ojjin] of Buddhas and bodhisattvas. The god Susa-no-o initiated composition in thirty-one syllables with the "many-layered fence at Izumo." Japanese poems do not differ from the words of the Buddha. ${ }^{61}$

Mujū presents an interesting extension of the argument that the Shinto gods express themselves through Japanese poetry; he claims that waka constitute mystical verses or dharani. The close ties between Shinto and the esoteric sects of the Tendai and Shingon schools contributed in no small measure to this belief. The Shingon school held that the three mysteries (sanmitsu) of the body, speech, and thought of the Buddha could be communicated to human beings through certain ritualistic prescriptions. ${ }^{62}$

61. Morrell, Sand and Pebbles, 163. Watanabe Tsunaya, Shasekishū, 223.

62. The Shingon (True Word) sect was established in Japan by the great priest Kūkai, better known by his title, Kōbō Daishi, after he returned from a period of extensive study in China in 807 . Shingon is a translation of the Sanskrit term mantra, a mystic doctrine that cannot be expressed in ordinary words. 
The means of communication had three aspects: physical gestures such as the mudra (which involved particular ways of intertwining the fingers), mystical verses (mantras and dharani), and yogic concentration. It was through these rituals that a devotee was able to realize within himself his own innate Buddhahood. Since esoteric teachings transcended verbal explanation and could not be grasped through discursive forms of writing, it could be argued that poetry, because of its very brevity, was the most appropriate form through which to intuit the Buddha's dharma. This was in fact precisely what Muju argued:

Japanese poems do not differ from the words of the Buddha. The dharani [mystic verses] of India are simply the words used by the people of that country which the Buddha took and interpreted as mystic formulas. For this reason, the Meditation Master, I-hsing, in his Commentary on the Great Sun Sutra, says, "The languages of every region are all dharani." Had the Buddha appeared in Japan he would simply have used Japanese for mystic verses. . . Although dharani employ the ordinary language of India, when the words are maintained as dharani, they have the capacity to destroy wickedness and remove suffering. Japanese poetry also, uses the ordinary words of the world; and when we use waka to convey religious intent, there will necessarily be a favorable response. When they embody the spirit of the Buddha's dharma, there can be no doubt that they are dharani. The words used in India, China, and Japan differ, but their meanings are mutual and their results the same. Through them Buddhism spread, its doctrines were accepted, and the benefits have not been without avail. ${ }^{63}$

A familiarity with the esoteric practices of Tendai and Shingon inspired many poets and priests to regard poetry with the utmost seriousness, and to take it up as part of their religious practices. Saigyo, who had strong ties with Mount Koya, the center of Shingon practices, is credited with having taught many a venerable priest the true significance of Japanese poetry. In Togano

63. Morrell, Sand and Pebbles, 164. Watanabe Tsunaya, Shasekishü, 222-23. See also Yamada Shōzen, "Chūsei goki ni okeru waka soku darani no jissen," Indogaku bukkyōgaku kenkyū 16.1 (December 1967). For a discussion on waka as dharani, see Yuasa Yasuo, The Body: Toward an Eastern Mind-Body Theory (Albany: State University of New York Press, 1987), 101-3. 
o Myōe shōnin denki (Biography of the Priest Myōe), it is related that Saigyō visited Myōe (Kōben, 1173-1232) and said to him:

Waka is the true form of the Buddha. Reciting one line of waka is equivalent to carving one statue of the Buddha; likewise continuing to meditate on one verse of waka is like reciting the sacred esoteric texts of Shingon. It is through poetry that I have mastered the law. ${ }^{64}$

In Shasekishū Mujū relates how Saigyō, after he became a recluse, received instruction in the innermost meaning of the Tendai mantras (shingon). When he was asked by the abbot Jien to communicate these teachings to him, Saigyo is said to have replied, "To begin with, practice writing poetry. If you do not understand poetry you will not understand the essence of the mantras." It is said that it was only after Jien became an adept at poetry that Saigyō transmitted the esoteric teachings to him. ${ }^{65}$

Thus a justification of poetry emerged from within the Tendai and Shingon doctrinal positions, as well as from the assimilation of native practices into Buddhism through the workings of the notion of honji suijaku. For court poets such as Shunzei and Teika, poetry was a michi that had to be cultivated with the utmost dedication. It was seen as having a value that transcended all other concerns. A theory and practice of poetry that integrally linked it to Buddhist ideals and practices undoubtedly served to further establish poetry as worthy of pursuit.

At the same time, literati monks such as Myōe and Jien, who belonged to the ecclesiastical order and whose major preoccupation was with the study of the scriptures and the pursuit of the Buddhist path, also argued that Japanese poetry had a central place in Buddhist practice and that the true nature of the dharma could not be comprehended without devotion to the spirit of poetry. In Myōe shönin ikun (Posthumous Teachings of the Priest Myōe), Myōe writes:

If we look at people from times past, we will observe that every single one of them who has been a true follower of the Buddhist dharma has dedicated himself wholeheartedly to an artistic pursuit [suki] and has not unashamedly dabbled in many things without devotion to any one pursuit. ... In the past as well as today, Buddhists who are

64. Washio Junkei, ed.,Togano o Myōe shōnin denki, in Tōhō bukkyō sōsho, vol. 5 (Tokyo: Tōhō Bukkyō Sōsho Kankōkai, 1925), 287.

65. Watanabe Tsunaya, Shasekishū, 251. 
worthy of praise have emerged from among those who have devoted themselves to an art [suki]. Although writing poems of praise [shōshi] or participating in the composition of Japanese poetry [waka] and linked verse [renga] is by no means the same as the Buddha's dharma, those who dedicate themselves to such activities will eventually also devote themselves to the Buddhist way. They will be full of wisdom and their gentle dispositions will display great refinement. ${ }^{66}$

Despite the different perspectives from which Shunzei, the court poet, and Myōe, the influential prelate of the Kegon sect, approached the composition of poetry, they displayed remarkable agreement in their belief that poetry was an exalted artistic form that made an important contribution to the understanding of the dharma. For Shunzei, poetry and religious practice were one. Myōe, however, was careful to point out that they were not the same but went as far as to say that commitment to the one could create a state of mind that was conducive to the understanding of the other.

\section{The Aesthete-Recluses}

The necessity of collapsing the difference between artistic and religious practices also became the overriding concern of a rather different group of poet-priests. These were the religious recluses, or tonseisha, who played a particularly significant literary role in the twelfth and thirteenth centuries. The term tonsei, "escaping from the world," is to be distinguished from shukke, "leaving the family." The latter term implies leaving one's home and formally entering the priesthood, while tonseisha did not enter temple organizations, study the complex aspects of the religion, or write erudite doctrinal works. They rejected the institutional constraints of organized religion as well as those of court society. Music and poetry became a central part of the quest for spiritual purity. The Japanese scholar Mezaki Tokue has coined the term suki no tonseisha, "aesthete-recluses," to describe this group, who had renounced worldly life but sought enlightenment through the refined pursuits of poetry and music. ${ }^{67}$

66. Kubota Jun and Yamamoto Akio, eds., Myōe shōninshü (Tokyo: Iwanami Shoten, 1981), 213.

67. Mezaki Tokue, "Aesthete-Recluses during the Transition from Ancient to Medieval Japan," in Principles of Classical Japanese Literature, edited by Earl Miner (Princeton: Princeton University Press, 1985). 
Saigyo is regarded as epitomizing the ideal of the aestheterecluse. He chose to live in isolation in a thatched hut in the mountains, traveling frequently to sites famous for their natural beauty, which became the subject of his own poetic compositions. Senjusho is written with the purpose of teaching the Buddhist faith, yet there is a constant emphasis on the importance of poetic tradition. It seems very likely that the attribution to the highly acclaimed Saigyo is part of a conscious attempt to legitimize the place of poetry within an avowedly Buddhist discourse. Many of the stories in this collection are concerned with breaking down the dichotomy between poetic and religious practice. Support for this position is sought from a variety of Buddhist doctrinal teachings.

For instance, we are told about a priest of obscure origins who wandered about the capital with his body encrusted with dirt and wrapped in matting in place of clothing. He would occasionally recite nenbutsu or intone important passages from the sutras, but in general he tended to ignore the written scriptures. One day he visited a holy man named Gyozai, who asked him with deep earnestness to recite at least one word from the scriptures that would help clear Gyozai's mind of delusion. It so happened that morning glories beaded with dew were in bloom nearby. When the breeze caused the dew to fall, the priest sighed and recited the following poem:

$\begin{array}{ll}\text { Miru ya ika ni } & \text { Do you see how } \\ \text { Ada ni mo sakeru } & \text { The transparent morning dew } \\ \text { Asagao no } & \text { Disappears } \\ \text { Hana ni sakidatsu } & \text { Even before the brief bloom } \\ \text { Kesa no shiratsuyu } & \text { Of the morning glory? }\end{array}$

Then declaring, "This is true scripture," the priest departed and was not seen again. The narrator expresses deep admiration for the priest and draws on Zoku honchō ojöden (Further Japanese Tales of Religious Salvation) to point out that the priest was successful in achieving rebirth in the pure land. ${ }^{68}$ In this tale the priest chooses to recite poetry instead of the sutras and claims that poetry is the true scripture.

The author of Senjūshō goes so far as to endorse the priest's assertion of the superiority of poetry over the written scriptures. He points out that the priest's name appears in the "historical"

68. Nishio Kōichi, ed., Senjūshō, Koten bunkō, no. 370 (Tokyo: Koten Bunkō, 1977), 23. 
recording of the great priests of Japan who have attained enlightenment. As we shall see, the declaration of the superiority of poetry over prescribed Buddhist practices was often used as a device to establish that enlightenment was possible as much through poetry as it was through the religious texts.

The author of Senjüshō turns to different aspects of Buddhist doctrine to claim that the practice of poetry is identical with Buddhist practice. The priest Eien, we are told, held an important position at the Yamashina temple. Not only did he surpass others in wisdom, he was also a master of the six styles of poetry. At times he would seclude himself in the meditation hall and calm his mind by meditating on the dharma world (hökai). At other times he would sit under the cherry blossoms or under the moon and compose poetry in Japanese. One day a friend asked him, "Does poetry not interfere with your religious studies?” Eien replied:

Poetry makes the mind grow continually clearer. When we compose poetry, conceptualizing the feelings of love, grief, and pain in poetic terms, all these, being no more than the products of the mind, help us to realize the truth of the doctrine of consciousness only [yuishiki]. There are no dharmas outside the mind. They are mere fabrications of the mind. Why then do you ask me if poetry would disturb my mind and interfere with my studies? What a question! ${ }^{69}$

We are told that the friend's question causes Eien to weep. It is the friend's lack of understanding of the Buddhist teachings, in this instance of the Hosso school of Buddhist thought, that evoked this response. The Hossō, or Mere Ideation, school attributes the existence of the outer world to inner ideation. The whole world is illusory and a creation of, as well as an outward manifestation of, the mind, of ideation. For one such as Eien, who had achieved great understanding of the Hosso doctrine, the separation of poetry and Buddhist scholarship was meaningless, and it was the irrelevance of the priest's question as much as his ignorance of the ultimate meaning of the religious teachings that caused Eien to weep. The implication of the story is that a person who has achieved such a level of enlightenment is able to move smoothly from meditation to composing poetry without experiencing any sense of contradiction or difference. 


\section{Divergent Solutions}

It can be argued, then, that throughout the twelfth and thirteenth centuries the answers to the questions of the role and validity of literary writing, particularly poetry, and the nature of its exact relationship with Buddhism were sought from within Buddhist doctrine. The central concept underlying the notion that poetry and Buddhism did not occupy two separate realms but were in fact identical came from the Buddhist concept of nonduality (funi). Expedient means was a further elaboration of the fundamental truth of nonduality, and, precisely because it was based on nonduality, it was also an attempt to affirm the identity of the phenomenal and the absolute. Yet within the scheme of nonduality there is no possibility of a hierarchy of means and ends. It is for this reason that William LaFleur has suggested the term "modes" rather than "expedient means" as being a more appropriate translation of upaya. ${ }^{70}$ The teachings of the Lotus Sutra stress the notion of upaya, which can be understood as a variety of different modes, all of which are on a par with one another and which in different ways seek to explicate the Buddha's dharma to different people.

While at the theoretical level there is no contradiction between nonduality and upaya or höben, Japanese litterateurs implicitly accepted the notion of a hierarchy. This can be best seen in the use of the term kyogen kigo, which clearly categorized literature, and particularly poetry, as frivolous and then sought to salvage such writing on the grounds that it could serve as a means to a noble end, namely, Buddhism. Even those writers who sought a justification of poetry on the grounds that it was identical with scriptural writing nonetheless shifted their argument, sliding into what they saw as a more pragmatic and readily comprehensible position, namely that of poetry as expedient means. This tension between nonduality and expedient means, which did not exist at the doctrinal level, became a real one for both Japanese litterateurs and Buddhist priests.

The perception that secular writing constituted a problem had found its earliest articulation during the Heian period in Japan. One could say schematically that by the twelfth century two important traditions had emerged, a Buddhist tradition and a literary tradition. Both were highly valued elements of the culture; both had social and institutional networks in which they were 
embedded. Japanese literature, for instance, was dominated by poetry, which was cultivated with single-minded dedication as a michi. Poets took part in poetry contests, attempted to have their poems included in imperial anthologies, and were supported by the patronage of the court. The study of Buddhism was carried out in the monastic institutions of its various sects. Buddhist priests devoted themselves to religious practice, to the study of the sutras and commentaries, and to the composition of religious treatises. Because both traditions were important, and because they occupied the same historical and cultural space, neither could afford to ignore or dismiss the other.

Precisely because their social and institutional bases overlapped and crisscrossed, it would be incorrect to describe these as distinct or competing traditions. This ambiguous relationship at once set the ground for and formed the subject of a dialoguea dialogue not between two distinct elements nor between identities (which, of course, would render debate impossible), but between traditions that overlapped to such a degree that they were constantly moving toward each other, but without being able to effect a total union. This might account both for the acceptance of the implications of nonduality and for the necessity of subsuming literature within Buddhism through the notion of expedient means.

The conflict between literary and Buddhist practices became a central trope in a wide range of literary works. Thus, writers as different as the Heian court lady who wrote Sarashina nikki, the court poet Shunzei, and the recluse Saigyo all expressed an anxiety about the value of literary writing, so much so that this discomfort formed the stuff of their dreams. ${ }^{71}$ The poet Shōtetsu (1381-1459), in his Shōtetsu monogatari (Conversations with Shōtetsu, 1448), recorded that in his old age Shunzei had serious doubts about his poetic activities and worried lest they hinder his enlightenment. Shōtetsu wrote:

71. For example, in a prose introduction to a poem, Saigyō explains that he was invited by the priest Jakunen to contribute to a hundredpoem collection but chose to decline. Saigyō, who was on his way to the Kumano shrine, had a dream in which Tankai, the administrator of Kumano, in conversation with the great poet Shunzei, explained to the latter that even in their degenerate age, only the way of poetry remained unaltered. This appears to have reaffirmed Saigyō's faith in the way of poetry. See Watanabe Tamotsu, ed., Saigyō sankashū zenchūkai (Tokyo: Kasama Shobō, 1971), 1052-53. 
Even when Shunzei became an old man, he spent his days and nights doing nothing but composing poetry and failed to perform any religious practices toward his future lives. Worrying about his spiritual future, Shunzei secluded himself for seven days at Sumiyoshi Shrine. Full of lamentations, he prayed to the god with the following words, "If poetry is indeed a worthless pursuit, I shall set aside the path of poetry as of now and devote myself solely to religious observances that will help toward my future lives." On a full moon night of the seventh day, the deity of Sumiyoshi revealed himself to Shunzei in a dream and indicated that the way of poetry and the way of the Buddha were completely indistinguishable. It was then that Shunzei realized that the way of Buddhism was to be sought not outside of or separate from the way of poetry, and it reinforced his belief that the way of poetry had to be taken very seriously. ${ }^{72}$

Both the problem and its resolution are contained in Shunzei's dream. The identity of the way of poetry and the way of the Buddha is demonstrated to Shunzei by none other than a Shinto deity, who, as the manifestion of the Buddha in Japan, speaks with authority. In this instance the complex interplay of honji suija$k u$ and nonduality forms the basis of the alleged resolution of Shunzei's dilemma.

Thus a wide range of concepts-funi, hōben, honji suijaku, kyögen kigo, and so on-became an integral part of medieval discourse and was harnessed to the project of working out the implications that literary practices had for an understanding of Buddhism and vice versa. It is within this complex tradition, which had developed from the Heian period onward, that Kamo no Chōmei must be situated. Chōmei, perhaps more than most, made the tension between the urge to write and the ideal of renunciation the central trope in all his writings. Working within the Buddhist framework of nonduality and expedient means, Chōmei also used what had primarily been an aesthetic category, suki, to restate the relationship between aesthetic and religious ideals to his own satisfaction. As we shall see, the term suki provided him

72. Hisamatsu Sen'ichi and Nishio Minoru, eds., Shōtetsu monogatari, in Karonshü, Nihon koten bungaku taikei, no. 65 (Tokyo: Iwanami Shoten, 1961), 184. See also Robert H. Brower and Steven D. Carter, trans. and ed., Conversations with Shōtetsu (Shōtetsu Monogatari), Michigan Monograph Series in Japanese Studies, no. 7 (Ann Arbor: Center for Japanese Studies, The University of Michigan, 1992), 89. 
with a conceptual framework within which he could redefine the ideals of courtly elegance and artistic refinement to make them consonant with the spiritual values he espoused as a tonseisha.

Apart from the broader context within which Chōmei's response to literature and Buddhist practice can be located, an examination of the particular circumstances that shaped his life sheds greater light on the texts that Chōmei has left behind. 


\title{
Chapter Two
}

\author{
Kamo no Chōmei: \\ Court Poet and Buddhist Priest
}

While little is known about the lives of many well-known writers of the Heian and Kamakura periods, Chomei is something of an exception. Genealogies provide valuable information about the Kamo family, and the diaries and literary works of his contemporaries on occasion speak directly of Chōmei's personality or of his activities.

A certain amount of information about Chōmei's life can also be gleaned from his own literary works. His collection of poetry, Kamo no Chōmei shū, is the only surviving work written by Chōmei during the period when he was a courtier. The rest of his writings were composed after the year 1208, when he moved to Hino to live as a recluse. Mumyōsho, his treatise on poetry, is the only work that draws directly upon his life at court as an aspiring poet. Hosshinshu, his collection of religious tales, does not refer to his own life. In Hōjoki, however, there is much information on his life and times; for instance, he describes at length the many disasters that afflicted the capital during his youth. The work also provides an insight into Chomei's reclusive life, which for him was a lived experience rather than a purely literary construct.

It is important to note, however, that in his writings Chömei presents us with his literary persona and not himself. Thus, apart from the instances when the veracity of his statements can be corroborated by other contemporary accounts, his works must be treated first and foremost as literary constructs that preclude any easy conflation of the writer and his literary mask.

A study of Chōmei's literary works would be incomplete without some discussion of the milieu within which he wrote and lived and the particular circumstances that shaped his life. The purpose of this chapter, then, is twofold. First, the chapter at- 
tempts to reconstruct Chōmei's life as a poet, beginning with his earlier, more private poems and continuing to the period from 1181 to 1204 , when he became a court poet who was seriously involved in the poetry contests of the times and who played an active role in the compilation of the imperial anthology of poetry, Shinkokinshu (New Collection of Ancient and Modern Times, 1206). Mumyōshõ provides ample material from this period that points to Chōmei's ambition to become a poet of note and to the measure of success he achieved in this sphere. Second, the chapter focuses on the circumstances that brought Chōmei to a major turning point, leading him to leave the capital and take the tonsure in 1204. The life of a low-ranking courtier who had found a somewhat tenuous point of entry into the world of the high aristocracy through his poetry, which, from all accounts, he took with the utmost seriousness, underwent a dramatic change. He became a religious recluse, devoted to the way of the Buddha.

\section{The Minamoto no Ienaga Diary}

It may be well to begin this inquiry with the available explanations of that critical transformation in Chōmei's life. Minamoto no Ienaga's diary (Minamoto no Ienaga nikki) contains the fullest statement we have regarding the major concerns in Chömei's life and the reasons for his leaving the court and taking the tonsure (see appendix one). This diary was an account of the public events that marked lenaga's life at court, and it begins with a description of his first days at court in 1196 . Ienaga was actively involved in the compilation of Shinkokinshu, and his diary provides invaluable information on how the poems came to be composed, edited, and revised. Kamo no Chomei worked with lenaga in the wakadokoro, or Bureau of Poetry, and was thus a person with whom Ienaga was well acquainted. lenaga writes:

People who devote themselves to any one thing, no matter how inconsequential, are bestowed with extraordinary favors by the emperor. And yet Chōmei failed to realize his aspirations! This, I have been told, is entirely because of his karma from previous lives. Anyhow, this person Kamo no Chōmei, after becoming an orphan, ceased to take part in affairs relating to the shrine and lived in seclusion. But because of his reputation in the field of poetry, he was summoned by the emperor, and he soon became an official at the Bureau of Poetry. From that time onward he would take part in all functions relating to 
poetry and would compose poems at all the regular poetry contests. He never left the bureau and worked there day and night with the greatest diligence. Just around the time when the emperor was contemplating rewarding Chōmei should some appropriate occasion arise, the post of head official [negi] fell vacant at the Lower Kamo shrine. Everyone was convinced that this time the emperor would ensure that Chömei got the post. Even before Chömei had expressed his interest in this appointment, it looked very much as though it would be his. When this rumor reached Chōmei's ears, he appeared unable to control his tears of joy.

However, we are told that Sukekane, who was head intendant of the shrine at that time, protested in no uncertain terms, pushing the case for the appointment of his own son, on the grounds that he held a higher rank and that he had devoted himself to the affairs of the shrine much more than Chomei had done. Ienaga goes on to explain how the emperor was forced to give up his earlier plan:

Hearing all this, the emperor felt that everything was in Sukekane's favor. He then decided to upgrade a smaller shrine that was affiliated to the main Kamo shrine, to accord it the same status as the latter, and to create the post of head official for this shrine, to which Chōmei could then be appointed.

However, Chōmei turned down the emperor's offer. Ienaga suggests that this "stubbornness" arose out of Chomei's feeling that he had failed to get what he had wanted in the first place, and even wonders if Chōmei was not "out of his right mind" in refusing such an attractive proposition. He continues:

After that I heard that he had gone into total seclusionno ordinary matter. He did not say where he was, but after some time had elapsed, he sent fifteen poems that he had composed to the emperor. . . The rumor was that he had taken the tonsure and was quietly carrying on with his religious practices at Ōhara. I felt that he was a person who carried things too far, but Chömei probably thought of this world as a deluded dream, in which, due to certain karmic links from previous lives, he had been strongly fated to enter the true path. ${ }^{73}$

73. See Ishida Yoshisada and Satsukawa Shūji, eds., Minamoto Ienega nikki zenchūkai (Tokyo: Yūseidō, 1968), 104-5, 110. 
Ienaga also describes how the emperor at one stage ordered him to send a messenger up to Ōhara to find out if Chōmei still had the biwa called Tenarai. Chōmei sent back the biwa with two poems written on the plectrum: these poems expressed his sense of loss at parting with the biwa, an instrument that had obviously come to be a symbol of his love for music and his life at the court. Ienaga concludes:

After that, when I met him again quite by chance, he had
grown so thin and shrunken that I could hardly recognize
him. He said, "If I had not deeply resented the society I lived
in, the darkness of this fleeting world would not have be-
come illuminated for me." Weeping copiously, he wrung the
sleeves of his priestly robes, drenched in tears. He went on,
"Although I have cast aside thoughts of worldly life, there is
still something that holds me back a little," and, pulling out
from his sutra bag the plectrum of the biwa on which I had
written the replies to his poems, he added, "Somehow this
will accompany me beneath the moss and will decay with
my body." I felt extremely sorry for him when I realized that
he found it so hard to forget and reject what he had set his
heart upon, and that he was convinced that his attachment
would even be a hindrance to the religious path he had taken. ${ }^{74}$

JIKKINSHŌ AND BUNKIDAN

Jikkinshō also has a short section on Kamo no Chōmei, which sets out to illustrate that even the deluded state of mind of one who harbors resentments in this world can, on occasion, become the means by which the person enters the true path. The author of Jikkinshō tells us that Chomei belonged to a family of officials of the Kamo shrine and that he was well-known as one who was deeply devoted to the ways of music and poetry. He wished to become head of the Kamo shrine, but as things did not go according to his wishes, he bore the world a grudge and took the tonsure. The author points out that even after Chōmei began to live in seclusion in his hut, he had his koto and biwa by his side, and he would amuse himself by playing music between his recitals of the nenbutsu. He concludes with the following statement: "The fact that he was unable to give up indulging in the pleasures of music is a reflection of the extent of his most admirable devotion [suki] to the way of music."75

74. Ibid., 110-11.

75. Izumi, Jikkinshō, 2:91-92. 
A rather different account of Chōmei's decision to take the tonsure appears in a treatise on music called Bunkidan (Tales Recounted by the Priest Bunki), which was probably written between the years 1278 and 1288 , more than sixty years after Chömei's death. According to this work, Chōmei, who was Nakahara Ariyasu's music pupil, had received instruction in the performance of one of the secret melodies, the yoshinsō. Because of Chōmei's passionate involvement in the art, he invited several acclaimed musicians to the Kamo shrine, where the incident that came to be known as the hikyoku zukushi (the playing of the secret melodies) took place. Bunkidan tells us that Chōmei performed the takuboku melody on his biwa. This was a secret melody that had not been transmitted to him by his teacher, and hence he was not authorized to play it. This fact leaked out and came to the ears of Fujiwara no Tadamichi (1165-1237), who was at that time in charge of the Imperial Court Music Hall. Tadamichi pointed out to the cloistered emperor Go-Toba that among the secret teachings of the way of music, this particular melody had been accorded special importance and had its own traditions of transmission; hence, for someone like Chōmei, who belonged to a low rank, to play this melody in front of a large audience and without formal instruction was a serious crime.

According to Bunkidan, Chōmei admitted to having played the takuboku but claimed that it was the extremity of his commitment to the way (michi ni fukeru kokorozashi no setsu naru koto) that had led him to do so. Go-Toba did not consider what Chōmei had done a grave crime, but Tadamichi protested strongly, saying that any violation of the way would set an unfortunate precedent for deviation from authorized practice. Bunkidan concludes that it was for this reason that Chomei had to leave the capital and thus decided to follow the way of religion. The account goes on to say that Chōmei built himself a ten-foot-square hut at the Bay of Futa$\mathrm{mi}$ and spent the rest of his life there. ${ }^{76}$

Several interesting features emerge from these different accounts. The first and quite undisputed one is Chōmei's deep involvement with music and poetry. This passion was so great that, as Ienaga's account has it, Chömei found it hard to part with the plectrum of his biwa even after becoming a priest, though in the end he felt constrained to do so. His correspondence with the

76. Wada Hidematsu, ed., Bunkidan, Matsuura hakushaku bunkō (Tokyo: Gakusaidó Tosho, 1918), 5-8. 
emperor and his meeting with Ienaga reflected his continued involvement with the world of poetry, which he had ostensibly left behind. However, his passion was also accompanied by the fear that such artistic activities were pointless and even deleterious to the Buddhist cause that he had espoused.

A second feature of Chomei's life emerges from the statement about his disappointed hopes at court. Chōmei had hoped to follow in his father's footsteps, gain some social standing in that way, and continue his pursuit of music and poetry. Both Ienaga's diary and Jikkinshō suggest that Chōmei's failure to achieve these worldly ambitions changed the course of his life. He chose renunciation over the life of a low-ranking and frustrated courtier.

It will be observed, of course, that Bunkidan gives a rather different account of the reasons for Chomei's departure from the court and his taking of the tonsure. There are, however, questions regarding the authenticity of this account. There is no mention of the incident that Bunkidan speaks of in Ienaga's diary, which ends in the eleventh month of the year 1207. Ienaga himself was an accomplished musician, and this event, had it occurred, would surely have created enough of a furor at court for Ienaga to write about it. Another factor that has led scholars to question the authenticity of this version is that among the musicians listed as having participated in the gathering at which Chomei played the secret melody are people like Fujiwara no Sanetoshi, who in the year 1204 (the approximate date of Chōmei's departure from court) was only eleven years old, and Fujiwara no Morikane, who at the time was fourteen. ${ }^{77}$

Both Jikkinshō and Ienaga's diary name Ōhara as the place where Chomei went after taking the tonsure. Bunkidan stands at variance with these, for it describes Chomei as going to the Bay of Futami and spending his life there. It is interesting that the name Futami, traditionally associated with Saigyo because it was where he had his hut, is linked in Bunkidan with Chōmei. The conflation of Chōmei with Saigyō is perhaps another reflection of the way in which, at least in literary memory, the two had become inextricably linked as the idealized figures of the poetic and reclusive traditions.

However, the story about Chomei in the Bunkidan is fascinating for what it tells us about the way of music and its tradi-

77. Iso Mizue, "Hikkyoku zukushi jiken o megutte, sono ni," Kamo no Chōmei no kenkyū 2, Nishō Gakuen Daigaku, Kishi Zemihen (June 1976). 
tions and above all about Chōmei's reputation as a sukimono whose extreme involvement in music prevented him from confining himself to the rules and norms of that tradition. Even if the account in Bunkidan is an apocryphal one, it does indicate that a legend had developed around Chomei's obsessive passion for the arts and his disregard for the social conventions that governed these arts.

After his departure from the court and his acceptance of the Buddhist path, Chōmei's life took a dramatically new course. But if Ienaga's account is to be believed, he was unable to shake off altogether his attachment to poetry and music, which had played such a central part in his life as a courtier.

\section{THE EARLY Years}

Kamo no Chōmei, or Kamo no Nagaakira as he was known at the time, was born in 1155, the eldest son of Kamo no Nagatsugu, the superintendent of the Lower Kamo shrine. ${ }^{78}$ This shrine was situated at the confluence of the Kamo River, flowing from Kitayama, and the Takano River, flowing from the direction of Ōhara. The deities worshipped at this shrine are the Kamo Taketsunomi no Mikoto and the Tama Yorihime. Together with the Upper Kamo shrine, the Lower Kamo shrine was held in great veneration by the court aristocracy. The Kamo festival held in the middle of the fourth month was referred to simply as "the festival" by the courtiers, an indication that it had come to be the single most important Shinto festival. The shrine's power was not purely spiritual: owning a large amount of land around its precincts, it wielded considerable material power, as did many of the Buddhist temple complexes of the time.

According to the various genealogies of the Kamo family, Chōmei had a brother called Nagamori, who at some stage had been accorded the fifth rank. ${ }^{79}$ Although his name is mentioned in Chōmei's Mumyōshō, nothing is known about him $(M Y, 69)$. The same is true for Chōmei's mother. About his father, however, we know somewhat more. In the year 1160 , Chömei's father was promoted to the junior fourth rank, lower grade. The promotion is recorded in Fujiwara no Tadachika's Sankaiki (Mountain Pagoda Tree Chronicle).$^{80}$ On the twenty-seventh day of that year, the em-

78. Yanase Kazuo, Kamo no Chōmei no shinkenkyū (Tokyo: Kasama Shobō, 1962), 2.

79. Ibid.

80. Cited in Miki Sumito, Kankyo no hito: Kamo no Chōmei, Nihon no sakka, no. 17 (Tokyo: Shitensha, 1984), 2. This book is the main source used for the following account of Chōmei's life. 
peror Nijo (r. 1158-65) visited the Kamo shrine. Tadachika was in charge of the ceremonial dances on that day. Earlier, when the emperor Konoe (r. 1141-55) had visited the shrine, he had not bestowed any favors on Nagatsugu, and it was to make up for this that the emperor Nijo raised his rank. Chōmei also benefited from his father's good connections with the emperor, for the following year he was appointed to the fifth rank, junior grade, at the age of seven. This was done through the favor of the emperor's second consort (chūgū), Shüshi Naishinnō, also known as Takamatsu-in, who was the daughter of Toba-in and Bifukumon-in (1117-60).

Thus Chōmei's life would seem to have begun in auspicious circumstances. However, a setback came with the premature retirement and subsequent death of his father. The last mention of Nagatsugu as head intendant of the Kamo shrine appears in an entry for the twenty-ninth day of the eighth month of the year 1169 , in Hyohanki, the diary of Taira no Nobunori. ${ }^{81}$ His retirement seems to have been brought about by continued ill health, but undoubtedly there were also political factors at work. Scholars surmise that his death occurred sometime between the winter of 1172 and the spring of the next year. Chomei was eighteen or nineteen years old at that time. Nagatsugu's place as superintendent was taken by Sukesue, who was the son of Arisue, Nagatsugu's elder brother. At the same time, Sukesue's brother, Nagahira, was appointed provisional intendant of the Tadasu shrine, which was a branch of the Lower Kamo shrine.

In any case, after the death of his father, Chōmei and his brother Nagamori found themselves without a position at the Lower Kamo shrine. One of the first poems that Chōmei wrote, one he included in Kamo no Chōmei shū, was composed, as he says, "while looking at cherry blossoms the year after my father died":

Haru shi areba

Kotoshi mo hana wa

Sakinikeri

Chiru o oshimishi

Hito wa izura wa
Since spring has come,

This year too

The cherry blossoms are in bloom.

Where has he gone,

The one who lamented their scattering ${ }^{82}$

Another poem of the same period was later included in Fuboku wakashö (The Japanese Collection of Poetry), a collection of

81. lbid., 31 .

82. Yanase Kazuo, ed., Kamo no Chōmei zenshū (Tokyo: Kasama Shobō, 1971), 3. 
poems compiled by Fujiwara no Nagakiyo around the year 1310 . Chōmei's poem read:

\author{
Sakura yue \\ Kataokayama ni \\ Fuseru mi mo \\ Omoitogeneba \\ Aware oya nashi
}

\author{
Lying here on Mount Kataoka \\ In order to view the cherry blossoms, \\ He too is unable to realize \\ What he had hoped for \\ This poor orphan. ${ }^{83}$
}

It is perhaps his failure to inherit his father's position that he refers to when he speaks of the poor orphan who is unable to realize the hopes that his father had for him.

In Kamo no Chōmei shū there is an exchange of poems in which Chōmei again expresses his despair at the death of his father. He writes:

Sumi wabinu
Izasa koemu
Shide no yama
Sate dani oya no
Ato o fumubeki

\author{
Weary of living \\ Nothing remains but to cross \\ The mountain of death. \\ At least in this way I can follow \\ My father's footsteps.
}

Seeing this poem, Kamo no Sukemitsu, an official at the Lower Kamo shrine, replied with the following verse:

Sumi wabite

Isogi na koe so

Shide no yama
Weary of living

Do not hasten to cross

The mountain of death.

83. Ibid., 44. This poem employs the technique of allusive variation (honkadori) and harks back to the following poem, attributed to Prince Shōtoku Taishi, which was composed under rather different circumstances:
Shinateru ya
Kataokayama ni
Ii ni uete
Is he dead, I wonder?
Fuseru tabibito
Aware oyanashi
Lying on Mount Kataoka
Starving from lack of food,
This poor traveler,
Without a father.

The Kataoka mountain that Chōmei refers to is not the one that Shōtoku Taishi is said to have visited in Yamato Province. Mount Kataoka was another name for the Mount Kamo. While expressing his disappointment and sense of helplessness at the death of his father, Chomei skillfully uses his knowledge of the poetic traditions of his times. Chōmei says that he is not lying on Mount Kataoka starving. He has come there to view the cherry blossoms, which, judging by the poem quoted earlier, were deeply admired by his father. 
Kono yo ni oya no Ato o koso fume
It is in this world that you should follow Your father's footsteps.

To this Chōmei responded with the following poem:

\author{
Nasake araba \\ Ware madowasu na \\ Kimi nomi zo \\ Oya no ato fumu \\ Michi wa shiruran
}

If you have feelings for me

Do not misguide me.

For you alone know

The way to follow

My father's footsteps. ${ }^{84}$

There are several poems in Kamo no Chomei shü under the heading jukkai (personal grievances), and they appear to have been written soon after the death of Chōmei's father. One can read into these poems not only Chomei's grief and his resentment at not taking his father's place but also an awareness of the problem of worldly attachments, an awareness that is clearly Buddhist:

Yo wa sutetsu

Mi wa naki mono ni

Nashi hatetsu

Nani o uramuru

Ta ga nageki zo mo
I cast aside this world.

I look upon myself

As one who belongs to it no more.

What should I bear ill-will against?

Who should I lament over?

Or again,

\author{
Ukimi o ba \\ Ika ni sen to te \\ Oshimu zo to \\ Hito ni kawarite \\ Kokoro o zo tou
}

Standing outside myself, I ask my own heart, Is it because you wonder what can be done About this grief-stricken body That you love it so ${ }^{85}$

When Chōmei was in his twenties, several disasters hit the capital, and he writes about them at length in Hojoki ${ }^{86}$ However, as we shall see, the natural disasters of that period, together with the unsuccessful attempt at shifting the capital to Fukuhara in 1180 , find a place in his work only to illustrate the ephemeral nature of human life and human dwellings. They serve as a contrast to the life that Chomei chooses for himself by living in a ten-

84. Ibid., 15-16. Kamo no Sukemitsu was an official at the Lower Kamo shrine. According to Hyohanki, he was promoted due to a recommendation by Chomei's father. Perhaps this fact made it possible for Chōmei to seek support and consolation from him when he appears to have needed it most. See Miki, Kankyo no hito, 39.

85. Yanase, Kamo no Chōmei zenshū, 15.

86. Ibid., 17-27. 
foot-square hut in Hino. Chōmei makes no mention of the political upheavals that took place over the same period. ${ }^{87}$

\section{The Emergence of Chōmei as a Poet}

After the shock of his father's death, Chōmei became increasingly involved with composing poetry. His poetic mentor, the priest Shōmyō (1112-87), was a poet of some standing. Shōmyō had been close to Chōmei's father, so Chōmei was able to seek his advice. Indeed, there is some evidence that Shōmyō was the father-in-law of a head intendant at Kamo shrine. ${ }^{88}$ If this is so, then it is not impossible that Shōmyō was in fact the father-in-law of Nagatsugu, which would make him Chōmei's grandfather. Whatever the nature of the relationship, it is clear that Shōmyo took Chömei under his wing and served as his guide.

In the year 1175, Chomei took part in the Kikuawase (Chrysanthemum Contest) held by Takamatsu-in who, as we noted earlier, was responsible for appointing Chomei to the fifth rank. This was a contest in which the participants were divided into two groups, with each group being called upon to put forth a chrysanthemum with a poem attached to it. The poems were then judged, with one side or the other being declared the winner. Looking back at this event years later in his Mumyōshō, Chömei recounts an incident that occurred at that time. On this occasion, Chōmei composed the following love poem:

\author{
Sekikanuru \\ Namida no kawa no \\ Se o hayami \\ Kuzurenikeri na \\ Hitome zutsumi wa
}

\author{
Because it flows so fast- \\ This river of tears \\ Which I am unable to check- \\ The dike that protected me \\ From the eyes of the world has collapsed. ${ }^{89}$
}

87. These were the Hōgen and Heiji Insurrections of 1158 and 1159 , respectively.

88. See Asami Kazuhiko, "Hosshinshū no gentai to zōhō," Chūsei bungaku 22 (November 1977).

89. $M Y, 40$. This poem expresses the feelings of a woman in love. She weeps, perhaps having been abandoned by her lover, and her tears reveal her lovelorn condition to the world. See also Hilda Kato, "The Mumyōshō of Kamo no Chōmei and Its Significance in Japanese Literature," Monumenta Nipponica 23.3/4 (summer/autumn 1968): 357. While all translations from Mumyōshō are my own, I am indebted to this work, which I have consulted extensively. See also Hare, "Reading Kamo no Chōmei," 181. 
Luckily for Chōmei, he had the poem checked by Shōmyō, who pointed out that it had one major defect. The word used for the death of an emperor or empress is hōzu. Thus Chomei's use of the word kuzuru, the alternate reading of which is hozu, would have been considered inauspicious in the presence of the empress. Chomei writes that he was deeply grateful to be saved from a major faux pas, and that he produced another more appropriate poem for the occasion.

In Mumyōshō, Chōmei describes being counseled by Shōmyō on another matter of poetic etiquette. Shōmyō explains to Chōmei the strategies that can be used by a courtier if he is approached by indiscreet court ladies with poems to be answered or completed; he points to ways whereby the gentleman can maintain his poetic credibility without bringing ridicule upon himself ( $M Y, 59-60)$.

However, Shōmyō's patronage did not place Chōmei among the poetic elite of the court. Shōmyō was affiliated with the Rokujō school of poetry, which had taken second place to the influential Mikohidari school of Fujiwara no Shunzei, which received imperial patronage. Shōmyō had compiled an anthology of poetry, Nansenzai (Imperfect Collection of a Thousand Years), challenging Shunzei's imperial anthology, Senzaishü (Collection of a Thousand Years), compiled in 1188 . It is a measure of the lack of political support for the Rokujō faction that Nansenzai fell into oblivion, while Senzaishu gained considerable prestige and became part of the waka canon. The priest Shömyō's presence is barely discernible in the two later imperial anthologies, Shinkokinshü and Shinchoku-senshü (New Imperial Collection, 1234).

There is considerable uncertainty about whether or not Chōmei was married or seriously involved with any woman. In Hōjōki, Chomei claims that at the age of fifty, when he became a priest, he had no difficulties in giving up worldly life because he had never been burdened with marriage or children $(H K, 29)$. However, some unanswered questions remain. First, there is the fact that Chomei is referred to by another title, Kikudaifu. Some biographers have suggested that Kiku was the name of Chomei's wife's family and that he had taken that name as an adopted son-in-law. They argue that Chōmei spent his twenties in his grandmother's home because he was married either to his paternal grandmother's daughter (his aunt, a not uncommon practice among the aristocracy of that period) or to her granddaughter (his cousin). The reason Chōmei had to leave his wife's home, they suggest, was his 
inability to carry on his father's profession and thus provide his family with security and prestige. ${ }^{90}$

Among the love poems that appear in Chomei's collection of poetry, there are verses whose headnotes suggest that he was involved with women from the time he was a youth. Chomei's increasingly active participation in court life would have brought him into frequent contact with ladies, all the more so since he was deeply involved in the composition of poetry and its recitation at poetry contests. However, there is no real evidence of a wife and family in Chōmei's life.

\section{Chōmei's Training in the Way of Poetry}

Chōmei's first literary work, Kamo no Chōmei shū, is believed to have been completed in the year 1181, when he was twenty-six years old. It contains one hundred and five poems, most of which are divided into the prescribed dai, or topics, such as spring, summer, autumn, winter, love, miscellaneous, and so on. There are also poems that are more personal in nature, some of which have been quoted already.

Several poems in this collection, written by Chōmei in his youth, are of interest given our knowledge of the course that Chōmei's life would take thirty years later. For instance, the following poem, which he composed on "going to a temporary dwelling in a place in the mountains," is striking for Chomei's inability at the time to conceive of a life spent in solitude and austerity, something that he later idealizes and celebrates in Hōjoki:

\begin{tabular}{|c|c|}
\hline Kari ni kite & I who came momentarily upon this \\
\hline Miru dani taenu & make-shift abode, \\
\hline Yama sato ni & Painful even to behold, \\
\hline Tare tsurezure to & Wonder who passes \\
\hline Ake kurasuramu & $\begin{array}{l}\text { Lonely days and nights } \\
\text { In these desolate mountains. }{ }^{91}\end{array}$ \\
\hline
\end{tabular}

Yet the poem he wrote while "facing the moon and forgetting the west" is a foretaste of that tension between the religious and the mundane that marks Chōmei's writings in his later life:

Asa yū ni

Nishi o somukaji

To omoedomo
I had believed that

At no time of day or night

Would I turn my back on the west,

90. Miki, Kankyo no hito, 54-55, 124-25.

91. Yanase, Kamo no Chōmei zenshü, 14. 
Tsuki matsu hodo wa But while waiting for the moon to rise E koso mukawane I failed to do what I had resolved. ${ }^{92}$

It is not clear what inspired Chōmei to publish his own collection of poetry at this time. It has been suggested that he was encouraged to do so by Kamo no Shigeyasu, who was the head Shinto priest of the Upper Kamo shrine and a poet of some repute. Chomei appears to have been a frequent participant in poetry contests that Shigeyasu organized at the shrine and in his home. Shigeyasu also included four of Chömei's poems in a collection called Tsukimödeshu, which he put together in the year 1182 . It is possible that Chomei was encouraged by this support to bring out his own collection of poems, and he included in Kamo no Chömei shü the four poems that appeared in Tsukimōdeshu. ${ }^{93}$

Apart from the help that Chōmei received from the priest Shōmyō and Kamo no Shigeyasu, his most important relationship in the world of poetry was with the poet-priest Shun'e. It is from Chōmei's account in Mumyōshō that we learn of the special bond that existed between him and Shun'e:

The first words that Shun'e uttered to me after we had tied the bonds of a teacher-pupil relationship in poetry were, "Poetry is based primarily on traditional practice. If you rely on me as your true teacher, never forget this. I talk to you in this way because I believe that you will certainly be one of the poetic geniuses of our times. Never, never, even if you reach a stage when people recognize you, should you ever believe that you have reached perfect enlightenment in the art and thus put on airs." (MY, 68-69)

Shun'e was born in 1113 and was forty-two years Chōmei's senior. He became a priest at Tōdaiji at an early age but returned to the capital, where he spent at least forty years as an important member of the poetic world. One of his most significant contributions was the establishment of a poetry circle, which he called the Karin'en (Grove of Poetry). He organized monthly gatherings of literary figures to discuss and recite poetry in his own home and tried to bring together poets of different styles and rank. These included middle- and low-ranking courtiers, men of the warrior

92. Ibid., 16. The west in this poem stands for the pure land of Amida Buddha. Chomei's literary persona laments that he has turned his back on the Buddhist faith and has been drawn to the beauty of the moon.

93. Yanase, Kamo no Chōmei zenshū, 54. 
class, Shinto officials, Buddhist priests, and women who served at court. The Karin'en appears to have been active for at least twenty years, and Chōmei's Mumyōshō is in large part a recording of various stories and episodes that were the subject of conversation in these gatherings at Shun'e's home.

\section{Poetry AND the Pursuit of Success}

When Chōmei was in his thirties, he was forced to move out of his ancestral home into a place far less luxurious. Chōmei writes about this in his Hojokki. He explains that he lived for a long time in the house of his paternal grandmother but that he lost "his position" and fell on hard times. When he was in his thirties he built, after his own plans, a little cottage barely one-tenth the size of his ancestral home (HK, 28-29).

Yanase Kazuo has suggested that Chomei perhaps lived in his paternal grandmother's house because his father, not being the eldest son of the family, had inherited the mother's rather than the father's home. Yanase believes that it was the death of his father that forced Chomei to move out of his grandmother's home. ${ }^{94}$ As mentioned earlier, there are also suggestions that Chōmei might have been married to a young woman from his paternal grandmother's family. Whatever the reasons, it is clear that the move from his grandmother's home was, for Chomei, the first step toward a life of greater frugality and restraint.

Yet despite Chōmei's failure to inherit his father's post in the Kamo shrine and to continue to live in comfort in his grandmother's home, he seems to have been actively involved in court life and to have had many opportunities to prove himself as a poet of distinction. One important event Chōmei recounts with pride in Mumyōsho is the inclusion of one of his poems in the prestigious Senzaishū. Chömei writes:

When one of my poems was included in Senzaishü, I expressed my pleasure thus: "I did not come from a family that had practiced the art of poetry over generations. Nor was I a great composer of poetry. Furthermore, I was not recognized as an outstanding man of accomplishment of my time. Under these circumstances, it was a great honor for me to have one of my poems included in Senzaishu." $(M Y, 45)$

94. Yanase, Kamo no Chōmei no shinkenkyū, 7. 
The poet and musician Nakahara Ariyasu, Chömei tells us, was deeply impressed by Chōmei's humility and his lack of resentment against people much less worthy than himself who had poems included in this anthology.

Another interesting episode Chömei writes about in Mumyōshō took place a year after this. The incident tells us much about Chōmei's enthusiastic involvement in the poetry circles of his time and about his first taste of success. Chōmei writes that he composed the following poem under the heading "moon" at the Mitsuyuki poetry contest at the Kamo shrine.

Ishikawa ya

Semi no ogawa no

Kiyokereba

Tsuki mo nagare o

Tazunete zo sumu

\section{In Ishikawa}

The little brook of Semi

Is so pure that

Even the moon seeks it out

Therein to live and shine.

The poem failed because the judge, the priest Moromitsu, declared that it was unlikely that any river with the name Semi existed. However, dissatisfied with the judgment, Chomei had the poem looked at again by the priest Kenshō (ca. 1130-ca. 1210), who also could find no precedent for the phrase semi no ogawa. But he did not dismiss the poem altogether because he felt that it flowed felicitously; instead, he urged Chōmei to make inquiries with people who lived in that region to find out whether such a river actually existed. On meeting Kenshō again, Chōmei explained that semi no ogawa was in fact another name for the Kamo River and that it was mentioned in the annals of the Kamo shrine. Chōmei notes with pride that he was the first to introduce and legitimize the phrase semi no ogawa in poetry and that it was not long before poets like Takanobu and Kenshō used the phrase in their own poems. The final sanction for his poem came when it was included in Shinkokinshu several years later. ${ }^{95}$

Thus Chōmei was receiving instruction not only in how to compose good poetry but also how to play the game to his advantage. The incidents cited above indicate the degree to which success in poetry was linked with politics and the cultivation of good connections.

Around 1186 or 1190 Chōmei appears to have gone to Ise. There is considerable debate as to when the journey actually took 
place and why Chōmei undertook it. ${ }^{96} \mathrm{He}$ wrote an account of his trip, a kind of travelog called Iseki, which unfortunately has been lost. What remains are some of the poems with headnotes, which found their way into works such as Fuboku wakashō. Among these poems, there are some that already indicate his increasing involvement with Buddhist teachings. An example is the following poem, composed while visiting the shrine of Tsukiyomi (another name for the god of the moon) in Ise:

\section{Yami fukaki \\ Ukiyo o terasu \\ Chikai ni wa \\ Ware madowasu na \\ Tsukiyomi no kami}

\author{
In your pledge \\ To illuminate this fleeting world \\ Plunged in darkness, \\ Do not delude me \\ Oh god of the moon! ${ }^{97}$
}

Here Chōmei seems to allude to the notion of honji suijaku, which had gained popularity in Japan at the time. The Buddha who had pledged to illuminate the deluded world appears in this poem in the form of the Japanese god Tsukiyomi no Kami.

To another poem composed during the Ise trip, Chōmei appended the following headnote:

\begin{abstract}
When I was in Futami, I heard that people were getting together in the vicinity to perform the ten kinds of ceremonies of the Lotus Sutra. I felt that I would like to take advantage of this opportunity to be present for the ceremony. I sent word to that effect, but someone, possibly the patron who was sponsoring the ceremony, declined and told me to stay away.
\end{abstract}

Chōmei then composed the following poem:

\author{
Kokoro sen \\ Hitotsu minori no \\ Sue made mo \\ Futami no sato wa \\ Hito hedatekeri
}

Let us take note:

The degeneration of the Buddha's Teachings Has led the village of Futami

To discriminate among people,

Going against the One Dharma. ${ }^{98}$

96. Yanase Kazuo links the journey with Chomei's disgrace from playing the secret melody takuboku as recorded in the Bunkidan and dates it to 1186 . See Kamo no Chōmei no shinkenkyū, 15-16. Tsuji Katsumi, however, believes the journey to have taken place in 1190 . See "Kamo no Chōmei Ise gekō nenjikō," Koten ronsō (December 1982).

97. Yanase, Kamo no Chōmei zenshū, 36.

98. Ibid., 40-41. The phrase minori no sue suggests the degeneration of the dharma and the onset of mappo, a period in which people practice exclusiveness and discrimination even in matters to do with the Buddha's dharma. 
Apart from Japanese poetry there was another art to which Chömei devoted his energies-the way of music (kangen no michi). In Mumyōshō Chōmei speaks of the advice given to him by Nakahara Ariyasu. He points out that Ariyasu imparted to him extremely valuable esoteric teachings in the way of music and that he had been instructed with such openness because Ariyasu wished Chōmei to follow in his footsteps. ${ }^{99}$ Speaking of Chōmei, Jikkinshō says, "In recent times there was a person who belonged to a family of officials who served at the Kamo shrine called Kikudaifu Chōmei. He was renowned among people for his music." ${ }^{100}$ Bunkidan regards Chomei primarily as a musician and points out that he was highly regarded in the field of poetry as well. It also mentions the fact that Chōmei was instructed in the art of music by Ariyasu and had the reputation of being a person completely devoted to the art (sukimono). ${ }^{101}$ There is no evidence to suggest that Ariyasu was successful in initiating Chōmei as his successor. The death of Ariyasu must have been a serious blow to Chōmei's musical ambitions. By 1191 his friend Shoshin, with whom he is said to have traveled to Ise, died. The priest Shōmyō and Chōmei's teacher Shun'e had died a little earlier. Most of the people who had guided him and been his patrons when he was aspiring to be a poet of consequence had passed away. We know very little of Chōmei's activities during this period.

We do know that he took part in the Iwashimizu Hachiman poetry contest at the Wakanomiya shrine on the third day of the third month of 1191. The main organizer of this contest appears to have been Minamoto no Mitsuyuki (1163-1244), and the judge was the priest Kenshō. Both poets had been present when Chōmei had recited his poem, "Semi no ogawa," at another contest organized by Mitsuyuki. The participants at this meeting were followers of the Rokujo style of poetry and belonged mainly to the middle and lower rungs of the aristocracy or the priesthood. Though not among the most highly acclaimed poets of the day, thirteen of the

99. $M Y, 45-46$. Ariyasu came from a family of musicians and was a master of the biwa, the yokobue, the taiko, and the koto. He had mastered a wide range of musical instruments and techniques, and it was in recognition of this that he was put in charge of the Imperial Court Music Hall in 1194. However, he did not live to enjoy this position for long; he died sometime in 1195.

100. Izumi, Jikkinshō, 2:91.

101. Wada, Bunkidan, 6. 
thirty-two present had their poems included in Senzaishū. ${ }^{102}$ This period of Chōmei's life may be characterized as one in which he achieved a moderate degree of success as a poet, taking part in contests and occasionally having his poems accepted for inclusion in anthologies. However, his connections seem to have been, for the most part, with poets who themselves were at the peripheries. The center stage was dominated by poets such as Shunzei and Teika, who could take imperial patronage for granted.

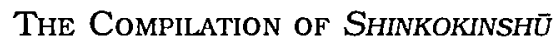

From the year 1200, when Chōmei was in his mid-forties, his fortunes changed. His most important patron at this time was the cloistered emperor Go-Toba. From 1198, after entering the cloisters, Go-Toba devoted his energies not only to politics and military affairs but also to the wholehearted promotion of the arts, particularly poetry. In 1200 he commissioned a series of hundredpoem sequences (hyakushu), a poetic form in which he had a special interest. The first was known as Go-Toba-in shoji shodo hyakushu (Cloistered Emperor Go-Toba's First Hundred-Poem Sequence of the Shōji Era). ${ }^{103}$ Twenty-three poets participated in this event. The second hundred-poem sequence was commissioned in the twelfth month of that year and was on a less grand scale, with only eleven participants. Among these, apart from Go-Toba himself, were Jien, Chōmei, Lady Kunaikyō, and Minamoto no Ienaga. The result was known as Go-Toba-in shōji saido hyakushu (Cloistered Emperor Go-Toba's Second Hundred-Poem Sequence of the Shojji Era). The success of the first had probably spurred him to hold the second, and this time he included poets like Chōmei, who were talented but of inferior status.

In that year Chōmei appears to have taken part in several other poetry contests. On the thirtieth day of the ninth month, he participated in the twenty-fourth poetry contest sponsored by GoToba, in which Shunzei was the judge. Three poems composed by Chōmei on this occasion have survived. On the first day of the tenth month, he took part in another poetry contest in eighteen

102. Miki, Kankyo no hito, 169.

103. See Robert H. Brower, Fujiwara Teika's "Hundred-Poem Sequence of the Shōji Era," 1200: A Complete Translation with Introduction and Commentary, Monumenta Nipponica Monograph 55 (Tokyo: Sophia University Press, 1978). 
rounds, again organized by the cloistered emperor. Chōmei presented three verses, of which one was declared a draw while the other two were losers. On the eighth day of the twelfth month, the Minamoto no Michichika poetry contest took place. Only one poem composed by Chömei on this occasion survives. On the twentyeighth day of the twelfth month the Iwashimizu Yashiro Utaawase was organized by Michichika, who also served as judge. Chōmei presented five poems: four were winners and one was a draw.

Shunzei's son, Fujiwara no Teika, was present at some of these contests. Although he and Chomei were almost the same age, they differed greatly in rank and in their standing as poets. Teika appears to have been keenly aware of Chōmei's inferior status. In his diary, Meigetsuki (Record of the Full Moon), there is an entry for the sixteenth day of the third month of the year 1201 in which he writes that although Chomei belonged to the fifth rank, he was a person of such humble origins that he should be taken as belonging to the sixth rank. ${ }^{104}$ Or again, speaking of the first of the contests held in the year 1200 , in which both he and Chōmei participated, he notes that Chomei took his place alone (being the only one present who belonged to such a low rank) away from the upper echelons of the nobility and the warriors. ${ }^{105}$ Clearly, Chōmei occupied a somewhat ambiguous and contradictory position at court. He was specially favored by the cloistered emperor because of his talent for poetry and his devotion to it; at the same time, he was looked down on by some of his colleagues at the Bureau of Poetry and by other higher-ranking courtiers.

In 1201 Go-Toba envisaged the production of an imperial anthology that could match Kokinshu. He reestablished the Bureau of Poetry in the seventh month of that year with the express purpose of organizing the compilation of Shinkokinshū. He thus revived an institution that had been inactive for two and a half centuries. Among those appointed as officials (yoriudo) were men of high rank such as the regent Fujiwara no Yoshitsune; the minister of the center, Minamoto no Michichika; and the Tendai head abbot, Jien. Below them in rank were Fujiwara no Ariie (11551216), Fujiwara no Ietaka (1158-1237), Fujiwara no Teika, Fujiwara no Masatsune, Minamoto no Michitomo (1171-1227), Minamoto no Tomochika, Jakuren (d. 1202), and Shunzei. Minamoto no

104. Imagawa Fumio, ed., Kundoku Meigetsuki (Tokyo: Kade Shobō, 1977), $1: 257$.

105. Ibid., 1:225. 
Ienaga was placed in charge. Within eight months more poets, of lower rank, were added to the Bureau of Poetry. These were Fujiwara no Takanobu (1 142-1205), Fujiwara no Hideyoshi, and Chōmei. Chōmei's inclusion as an official in the Bureau of Poetry (although he was still required, along with Takanobu and Hideyoshi, to occupy a special seat at a lower level than the high-ranking officials) was an index of the honor bestowed on him by the cloistered emperor. Chōmei's enthusiasm and dedication to his appointment are attested by Ienaga in his diary, where he writes that Chomei worked day and night and would never leave the Bureau of Poetry. ${ }^{106}$

There was nothing in Chōmei's life at this stage that would suggest that he would leave courtly life altogether and become a Buddhist recluse. A poem Chōmei composed on the fifteenth day of the eighth month of the year 1201, when he took part in a poetry contest held at the Bureau of Poetry, on the topic "The Moon at Dusk Deep in the Mountains," deserves special mention in this regard:

Yomosugara

Hitori miyama no

Maki no ha ni

Kumoru mo sumeru

Aki no yo no tsuki
All through the night

Alone in the mountain depths, I gazed at the autumn moon

That was clouded by the pine needles. Now at dawn it shines through clearly.

When Chōmei composed this poem, the physical setting he evoked was little more than a literary topos for him, and Chomei could not have imagined that this poetic conceit would later become a reality for him. After he became a recluse, Chōmei himself gave voice to this irony by alluding to this earlier poem. ${ }^{107}$

Among the poetry contests that Chomei attended in the year 1202 was the Eigu Utaawase. The eigu was a meeting held in memory of a famous poet in which the participants paid homage by composing poetry and drinking sake together. In Mumyōshō Chōmei describes one such monthly gathering at the home of Michichika, where Chomei composed the following poem to the title "The Moon and the Old Temple":

106. Ishida and Satsukawa, Minamoto Ienaga nikki zenchūkai, 104-5.

107. Miki, Kankyo no hito, 182. Ienaga quotes this poem, as well as Chomei's allusion to it in a subsequent composition, in his diary. See Ishida and Satsukawa, Minamoto Ienaga nikki zenchūkai, 109. 
Furinikeru

Toyora no tera no

Enohai ni

Nao shirotama o

Nokosu tsuki ka na
In the Enohai well

of the Toyora temple

Grown ancient over the years,

The moon leaves behind

Its glittering pearls unchanged.

Chomei tells us that when Shunzei heard this poem he could not help but be impressed and remarked, "This poem has truly been constructed with great elegance. I too had thought of using the phrase toyora no tera no enohai at an appropriate occasion, but alas, I have been beaten to it by you." Chomei explains that the phrase was taken from a saibara, a kind of popular folk song, and that it was known to everybody, but that he was the first person to have thought of using it within a poem. He notes with pleasure that later on Teika emulated him, using the phrase in one of his own poems $(M Y, 61)$.

Another interesting event that Chomei writes about in Mumyöshō occurred on the twenty-second day of the third month in the year 1202, at a time when, as Chōmei says, "I used to spend all my time at the palace" (MY, 77-78). The cloistered emperor GoToba organized a poetry contest in which he ordered everyone to compose six poems using three different styles of poetry (santai). According to Chomei, the prescribed form was that poems composed on spring and summer had to be weighty and large; on autumn and winter, slender and light; on love and travel, elegant and graceful. Many poets were daunted by the cloistered emperor's request, and even poets of some consequence like Fujiwara no Ariie and Masatsune, both compilers of Shinkokinshū, stayed away, feigning sickness. Even Teika, in his Meigetsuki, expressed the view that this was a rather unreasonable request on the part of Go-Toba. In the end only six poets participated in this gathering. They were Yoshitsune, Jien, Ietaka, Jakuren, Teika, and Chōmei. Chömei appears to have been a success at this unusual gathering; five of his poems were later included in Shinkokinshü.

Another memorable event in Chōmei's life as a member of the Bureau of Poetry was his excursion on the twenty-fourth day of the second month in the year 1203 to see the cherry blossoms at the palace, together with other members of the bureau. In his Meigetsuki, Teika notes that he went on an excursion to view the blossoms at the invitation of his fellow poets letaka and Masatsune. He mentions that Chomei was present as well. The expedition was a pleasant one, in which members of the party composed waka and renga and broke off sprays of cherry blossoms to attach to 
their poems. On the way back, everyone felt in the mood for a concert, and so Masatsune played the pipe (hichiriki) while Ienaga and Chömei played the flute (fue). Teika goes on to recount that when the cloistered emperor heard about the excursion the next day, he organized another cherry blossom party. Chomei was part of this august gathering as well, and he had occasion to compose poems with the other courtiers while sitting under the blossoms. ${ }^{108}$

This period was perhaps the high point of Chomei's poetic life. He took part in all the major poetry contests of the time and worked without respite in the Bureau of Poetry on the compilation of Shinkokinshü. Chomei had the unusual opportunity of working in close association with not only the highest-ranking aristocrats but also the cloistered emperor himself. In view of Teika's remarks about Chomei's inferior rank, this must have been a singular honor.

The cloistered emperor personally supervised every detail of the production of Shinkokinshu. For instance, when the compilers had the whole manuscript ready on the twenty-fourth of the fourth month in the year 1205, he went through the collection meticulously, suggesting corrections and rearrangements. The last record of Chomei's participation in the activities of the court is on the thirteenth day of the eleventh month, when he attended the ceremony at the Bureau of Poetry to celebrate Shunzei's ninetieth birthday. Chömei was among those who composed poems in homage to the grand old man of the world of waka. However, this life of refinement and elegance in which Chomei had steeped himself came to an abrupt end the following year, when he left the Bureau of Poetry, became a priest, and moved away from the capital.

\section{The Move to a Life of Seclusion}

According to Hōjōki, Chōmei became a priest in the spring of his fiftieth year, that is, in 1204: "Not having any family, I had no ties that would make abandoning the world difficult. I had no rank or stipend-what was there for me to cling to?" ${ }^{109}$ Chōmei does not mention the specific circumstances that led to his taking the tonsure. He refers in a general way to a life full of misfortunes and bad luck and points out that it was his recognition of the essential

108. Imagawa, Kundoku Meigetsuki, 2:26.

109. HK, 29. See Donald Keene, trans., "An Account of My Hut," in An Anthology of Japanese Literature, edited by Donald Keene, Penguin Classics (Bungay, Suffolk: Chaucer Press Ltd., reprint 1968), 197. 
frailty of worldly life that made him turn his back on it. From Ienaga's diary and from Jikkinshō we know that Chōmei's failure to succeed to his father's position at the Kamo shrine may have been the immediate cause of this departure.

Apart from Hojoki, there is no account that records the exact year Chōmei took the tonsure. We can, however, accept the spring of 1204 as a fairly accurate date because from that time onward Chōmei's name no longer appears among the participants at poetry contests. His name is conspicuously absent from among those who celebrated the completion of the Shinkokinshu project on the sixth of the third month in 1204.

In Hōjoki, Chōmei says that after taking the tonsure, he spent five fruitless years in the mountains of Ōhara. Ienaga's diary also mentions Ōhara as the place that Chōmei disappeared to after his departure from the court. Ōhara had come to be a haven for many Buddhist priests and recluses who wished to escape from the highly institutionalized environment at Mount Hiei. Many priests came down to Ōhara, at the foot of Mount Hiei, to lead a rather different kind of religious life-one in which music and poetry played an important part. In Senzaishü, for instance, there is a poem by Chikanori, who says that he composed the following poem, together with other priests, while living in seclusion at Ōhara. The dai, or topic, of the poem was capturing the spirit of the end of the old year in an atmosphere of seclusion:

Miyako ni te
Okuri mukau to
Isogishi o
Shirade ya toshi no
Ima wa kurenan

In the capital we bustled about Bidding farewell to the old And ushering in the new year, But now the year ends And passes by unnoticed. ${ }^{110}$

We do not know whether Chōmei made any friends during his period in Ohara, or whether he had the opportunity to take part in such poetry gatherings.

There was one person, an old friend of Chōmei's, who may have been instrumental in Chomei's choice of Ōhara. This was the priest Zenjaku, formerly Fujiwara no Nagachika. He had held a high position at court but took the tonsure in 1188 , when he was only in his mid-twenties. He later became a disciple of Hōnen (Nyōren Shōnin, 1133-1212). More popularly, he was known as

1 10. Matsushita Daizaburō and Watanabe Fumio, Kokkataikan, 2 vols., (Tokyo: Kyōbunsha, 1958), no. 475. 
the holy man of Ōhara. It was perhaps in emulation of Nyōren that Chōmei chose the religious name Ren'in, thus incorporating one character from his friend's name into his own.

After the five "forlorn" years spent in Ōhara, Chōmei, according to his account in Hōjoki, moved to Hino, a mountain village about seven kilometers southeast of the capital. It was here that Zenjaku is said to have established the temple known as Toyama-in. It seems quite likely that Zenjaku invited Chōmei to build his hut on Toyama. At the bottom of the mountain stood the temple complex of Hokaiji. Thus the place where Chomei built his hut, while in a secluded spot in the mountains, was not as isolated as Hōjōki would have us believe.

There is evidence to suggest that in the autumn of 1211 Chōmei made at least one journey to Kamakura with the poet Masatsune, who had been his colleague in the Bureau of Poetry. It is not clear why Chōmei undertook this journey, but we do know that he met the shogun, Minamoto no Sanetomo, there. Sanetomo was already, at the age of nineteen, deeply interested in poetry, and was receiving instruction in the art from Teika. Sanetomo had not as yet had the opportunity to meet his teacher, and his first contact with poets who had been involved with the compilation of the prestigious Shinkokinshü was with Masatsune and Chōmei. Chōmei makes no reference to this trip in Hōjoki and describes this period in his life as being entirely free of contact with the capital and with the friends who once shared his social world.

Toward the end of his life, Chōmei commissioned his friend Zenjaku to compose a $k \bar{s} s h i k i^{11}$ on his behalf. Chōmei, however, asked for a kōshiki on the moon, a request that lacked all precedent. It appears that Zenjaku did not carry out Chōmei's request quickly enough, and Chōmei passed away before the work was undertaken. Full of repentance, Zenjaku composed Gakkōshiki (The Order of Service in Praise of the Moon) and offered it on the thirtyfifth day after Chomei's death, with the prayer that the merit acquired from composing this work should be transferred to Chōmei's store of merit and thus help him attain Buddhahood. It is from Gakkōshiki that we can ascertain the exact date of Chōmei's death. Zenjaku dates his work the thirteenth of the seventh month in the year 1216. This places Chōmei's death on the tenth day of the

111. A kōshiki was a Buddhist work written in a literary style and dedicated to the Buddha. It was believed to bring merit, after death, to the person who commissioned it. 
intercalary sixth month of that year. ${ }^{112}$ The place and circumstances of his death, however, remain unknown.

112. A handwritten text of Gakköshiki, put together from extant manuscripts, was very kindly provided to me by Professors Iso Mizue and Mizuhara Hajime. 


\section{Chapter Three}

\section{The Way of Poetry: Mumyōshō}

The tension between literary writing and religious practice and the possible resolution of this tension, as we have seen earlier, became a popular topos for many writers of the Heian and Kamakura periods. Yoshishige Yasutane, for example, borrowed Po Chüi's phrase kyögen kigo to argue that writing poetry could be used as a means (hōben) for promoting the Buddhist cause. Poets like Shunzei, however, claimed that the very act of composing verse constituted a religious practice, and priests like Mujū Ichien, who were actively involved in preaching the faith, sought to give legitimacy to Japanese poetry by invoking the theory of honji suijaku.

In Chōmei's writings, suki becomes the linchpin that holds together two potentially contradictory impulses, namely, the urge to write, which implies an engagement with and an attachment to the world, and the imperative to abandon literary endeavor and to attain detachment from the world. Chomei found in the term suki the richness that allowed him to explore and redefine the relationship between art and religion. This is particularly true in Hosshinshu, as we shall see in the next chapter, but the term suki also occupies a central place in Mumyōshō, Chōmei's poetical treatise in which he delineates the qualities of the ideal poet. A consideration of the polysemic term suki is therefore a necessary prelude to a more informed reading of Chömei's texts.

The concept of suki was not Chōmei's creation. Both suki and the closely related concept irogonomi, often used synonymously, appear frequently in the literature of the Heian period. Both terms underwent important shifts in emphasis in the Kamakura period, reflecting the complex political, social, and religious changes of the twelfth and thirteenth centuries. Chomei drew upon 
the rich layers of meaning embedded in the term suki, using it, as in Mumyōsho, in the same way as his contemporaries; on other occasions, as in Hosshinshu, he stretched the term beyond the meanings that others had attached to it in order to make it consonant with the theme of religious enlightenment. ${ }^{112}$

Suki in the Heian period was a complex term initially closely associated with the cultivation and expression of love. The term irogonomi is formed from the combination of the noun iro (carnal love) and konomu (to have a fondness for), while suki is the noun derived from the verb suku (to have a passion for and commitment to the pursuit of someone or something). It is worth noting that the same character is used for both konomu and suku. Both terms came to signify a strong inclination to amorous activities pursued with total abandon.

In the context of the courtly culture, amorous dalliance was closely associated with such refined pastimes as the composition of poetry and musical performance. Irogonomi and suki thus signified not only a keen interest in the game of love, but equally the ability to express amorous concerns through the exchange of elegant verse. Irogonomi was used not only as an abstract noun but also to describe a person endowed with an amorous disposition and a connoisseurship of music and poetry. The word sukimono came to represent a person given to the pursuit at hand, undaunted by obstacles. ${ }^{113}$

The terms irogonomi and suki were closely linked with the broader aesthetic ideal of the Heian period, füryū, best exemplified by the lives of male aristocrats of this period (see pp. 34-35). Irogonomi and suki, I would suggest, were subsets of this larger category fūryú and appear to have been used to portray different combinations of the qualities that made up this ideal.

The word irogonomi, the Japanese rendering of the Chinese hao se (köshoku), appears for the first time in the writings of the

112. For a study of the trajectory of the term suki from Heian times, see Rajyashree Pandey, "Love, Poetry, and Renunciation: Changing Configurations of the Ideal of Suki," Journal of the Royal Asiatic Society 5.2 (July 1995): 225-44.

113. Ōno Susumu has suggested that suki in the Heian period was quite close in meaning to the modern Japanese word suki. It signified an unbridled flow of emotions toward a particular object or person and reflected a sense of pure enjoyment that was free of moral constraints. See Ōno Susumu, "Ōchō bungaku no kotoba," in Nihon bungaku kenkyū, vol. 2 (Tokyo: Shinchōsha, 1976), 50-51. 
Heian period. In its basic sense, the Chinese term refers to a fondness for sex. Chinese Confucian ethics saw hao se as being diametrically opposed to virtue and as a basic desire that had to be controlled. In Japan, by contrast, no well codified system existed that condemned these activities, and this is reflected in the literary works of the period. ${ }^{114}$ Indeed, amorous adventure was a central theme of Heian courtly literature.

\section{IROGONOMI IN ISE MONOGATARI}

One of the earliest literary works of the Heian period in which the theme of amorous dalliance (irogonomi) plays a central part is Ise monogatari (Tales of Ise), an anonymous work, completed around the first half of the tenth century, which brings together 125 short episodes about the amorous adventures of a man known simply as otoko (man) through much of the tale. There is, then, no named central character in this work, although popular tradition identifies the poet Ariwara no Narihira (850-80) with the male figure in the text.

The work can be seen as a celebration of the ideal of irogonomi-both the hero of the tale and the many women he encounters are naturally disposed to the pursuit of members of the other sex. Each episode describes the man's pursuit of a particular woman, his success or failure, the loss of interest that sometimes

114. One of the rare examples of a negative attitude to irogonomi appears in the preface of Kokinshü. In the Japanese preface, which was inspired in part by its Chinese counterpart, Ki no Tsurayuki uses irogonomi as the equivalent of kosshoku in the Chinese preface, and in so doing he adopts the Confucian disapproval for it. He writes: "But in our present age, only surface brilliance is valued. People's hearts have grown frivolous: they produce nought but frothy poems, inconsequential words. Poetry has fallen into decay and oblivion among men and women of fashion and dalliance [irogonomi], never blooming forth in proper circles." See Ozawa, Kokin wakashü, 54. For a translation of the Japanese and Chinese prefaces of Kokin wakashu, see Laurel Rasplica Rodd and Mary Catherine Henkenius, Kokinshü: A Collection of Poems Ancient and Modern (Princeton: Princeton University Press, 1984), 35-49, 379-87. Of the actual poems in Kokinshü, however, as many as five of the twenty volumes are devoted to the theme of love and present poems that lovers would exchange in private. The way in which irogonomi is used in the preface reflects the great gap that existed between Japanese sensibilities and the Chinese moral ethic. See Nakamura Shinichirō, Irogonomi no kōzō (Tokyo: Iwanami Shoten, 1985), 22. 
ensues, and the next lady who captures his interest. While the stories in Ise monogatari revolve around the male figure, both men and women participate actively in amorous sport, and both are described as irogonomi. Indeed, the men in the tales are particularly drawn to women who are irogonomi. ${ }^{115}$

Central to these romantic relationships is a sense of refined sport (asobi) that finds expression above all through poetry. In the text, the skill and sensitivity with which feelings are communicated through poetry temper all amorous relationships. To be a good poet, then, was a prerequisite for being an irogonomi.

Another quality of the ideal irogonomi was his pursuit of the object of his desire undaunted by obstacles and practical considerations. Indeed, on occasion these amorous adventures break well-established taboos and challenge the authority of those in power. ${ }^{116}$ The outstanding achievements of the male figure in Ise monogatari are his abduction of ladies of high standing, like the consort of the second ward, his relentless pursuit of the emperor's favorite, and, perhaps most outrageous of all, his seduction of the high priestess of the great Ise shrine. This tenacity of purpose, this total commitment to the pursuit at hand, is a central feature of the ideal of suki and is present in the notion of irogonomi as well.

\section{Genji Monogatari : The Emergence of Suki as a Male Ideal}

The most important literary work of the Heian period, Genji monogatari has as its central theme the life of the nobleman Genji and his affairs with numerous women. It is not surprising, then, that the terms suki and related compounds such as sukimono, sukigokoro, sukiwaza, sukizukishi, as well as irogonomi, are used extensively in this work. In Genji the range of meanings accorded suki is further extended. Thus suki is now used to signify not only

1 15. The uncertainty of a woman's fidelity often rendered her even more attractive in the eyes of men. See Katagtri Yõichi, et al., eds., Ise monogatari, in Taketori monogatari, Yamato monogatari, Ise monogatari, Heichü monogatari, Nihon koten bungaku zenshū, no. 8 (Tokyo: Shōgakkan, 1972), 165; Helen Craig McCullough, trans., Tales of Ise: Lyrical Episodes from Tenth-Century Japan (Tokyo: University of Tokyo Press, 1968), 95-96.

116. For an analysis of Ise monogatari as a subversive text that challenges the authority of the Fujiwara aristocracy, see Marra, The Aesthetics of Discontent, 30-43. 
amorous intent but also skill and sensitivity in the artistic world. Concomitant with the broadening of the semantic range of these terms, there is another tendency particularly striking in Genji. These terms, when used in the context of amorous escapades, now emerge as predominantly male ideals. This is in marked contrast with their use in Ise monogatari.

There has been much debate among scholars about the attitude of the author of Genji, Murasaki Shikibu, toward amorous sport. Through an examination of the use of the word suki in this work, scholars have claimed either that Shikibu fully endorses lustful impulses or that moral considerations led the author to condemn them. ${ }^{117}$ Part of the problem with both positions is the assumption that the views expressed by the characters are necessarily those held by the author. Such an assumption is problematic for a reading of any text; Genji, in particular, defies thematic generalizations, offering as it does a multiplicity of meanings and voices. ${ }^{118}$ Suki and its related compounds, as we shall see, cover a wide range of situations and emotional states, and the polysemic nature of these terms arises, among other things, out of the fact that, depending on their age, gender, political position, and so on, characters in the novel imbue these terms with positive or negative connotations.

Genji, as seen through the eyes of the other male characters, is irresistible to women, and his amorous activities meet with their approval. In the "Yūgao" chapter, for example, Genji's close friend and attendant, Koremitsu, reflects on Genji's growing interest in Yügao with approval and indulgence: "Given the fact that Genji was so young and attractive to women, it would be quite heartless and bespeak a certain inadequacy if Genji were to refrain from such amorous relationships [suki tamawazaramu mo

117. See Yoshizawa Yoshinori, Gengoshakusen (Tokyo: Seiwa Shōin, 1950), 174. Also see Kinoshita Masao, Heian jōryū bungaku no kotoba (Tokyo: Nihon Bunpó Shinchō, 1968), 50, where he translates the word suki as kōshoku.

118. As Amanda Stinchecum has pointed out with regard to the Uji chapters, the very fragmentation of voice and points of view in The Tale of Genji "confounds our attempts to arrive at a final interpretation of the work, and may indeed be the only interpretation we can reach." See her Ph.D. dissertation, "Narrative Voice in the Tale of Genji," Illinois Papers in Asian Studies, vol. 5 (Champaign-Urbana, IL: Center for East Asian and Pacific Studies, University of Illinois, 1985), 15. 
nasake naku sōzōshikarubeshi]."119 Similarly, Genji's father, the emperor, seeing Genji flirt with one of the older ladies-in-waiting, Gen no Naishi, laughs indulgently and comments with a smile, "People often lament that you are wanting in amorous enterprise [sukigokoro], but I can see you have your ways." 120

It is worth noting, however, that the same emperor is extremely distressed that Genji is neglecting the Rokujo lady, the emperor's niece, and he reprimands Genji thus, "If you abandon yourself to the dictates of your heart and indulge in these amorous affairs, you will certainly bring upon yourself the opprobrium of society [kokoro no susabi ni makasete kaku sukiwaza suru $w a] . "{ }^{121}$ In this instance the emperor's criticism flows from the fact that his niece, who is of high status, is being neglected. While love affairs are in themselves not reprehensible, abandoning oneself to one's desires in this case is inappropriate and best avoided. In this work we see how moral judgments are contingent on status.

It is significant that the male characters make it amply clear that women who are irogonomi or sukimono cannot be taken seriously. In the "Hahakigi" chapter there is a famous passage in which Tō no Chujō and Genji discuss the relative merits and shortcomings of women. They are joined by two courtiers, a guards officer and a functionary in the Ministry of Rites. These two men are described as "great lovers and good talkers lyo no sukimono ni te mono yoku iitoru ol." 122 On the chance arrival of these men, Genji and his companion immediately ask their opinion on the criteria by which women should be evaluated, as a mark of deference to their expertise in the art of love and their ability to express themselves well.

The two men proceed to judge women who are sukimono. The guards officer, for instance, reminisces about a lady of whom he had become enamored: "Everything about her told of refinement. Her poems, her handwriting when she dashed off a letter, the koto she plucked a note on-everything seemed right. She was clever with her hands and clever with words." Eventually the officer discovered that the lady was having an affair with another man. He witnessed her exchanging poems with and playing the

1 19. $G M, 1: 217$.

120. $G M, 1: 410$.

121. GM, 2:12.

122. GM, 1:134; Arthur Waley, trans., The Tale of Genji (Tokyo: Charles Tuttle, 1970), 23. 
koto skillfully for her other lover. The guards officer draws the following conclusion from this affair:

Though I had to admit that she had talent, I was very annoyed. It is amusing enough, if you let things go no further, to exchange jokes from time to time with fickle and frivolous ladies Itada toki doki uchi katarau miya zukae bito nado aku made zarebamisukitaru wa sate mo miru kagiri wa okashiku mo arinubeshi]; but as a place to take seriously, even for an occasional visit, matters here seemed to have gone too far. I made the events of that evening my excuse for leaving her. ${ }^{123}$

He challenges his listeners to give their hearts to a lady who is given to amorous sport (sukitawameramu onna ni kokoro okasetamae) and assures them that such an involvement can end only in damaging their reputations. Frivolity and flightiness, then, were acceptable only in a woman whom a man had no intention of taking seriously.

The men in Genji all see it as their prerogative to assess, categorize, and rank the women they know. Women cannot, in their view, be taken seriously as long-term partners if they are irogonomi or sukimono. When applied to women, these terms all too quickly take on negative connotations, signifying, above all else, inconstancy and unreliability. Young girls of the aristocracy were not allowed amorous dalliance and were expected to show the kind of constancy that Lady Murasaki, for example, showed to Genji.

A rather different moral code applied to the ladies-in-waiting at court, who were expected to flirt and to engage in repartee with courtiers. In Genji, the serving women (nyōbō) who work for women of the aristocracy often actively encourage noblemen in their advances to their reticent mistresses. They seem entirely uncritical of the male irogonomi and often get their inexperienced mistresses into trouble with their indiscretions.

We are able to get a glimpse of the attitude of noblewomen in Genji toward men who are inveterate seekers of romantic escapades through the responses of leading characters such as Lady Murasaki :

As usual when Genji was away, Murasaki had her women read stories to her. In the old stories that were supposed to tell what went on in the world, there were men who 
lacked all sincerity [ada naru otoko], men who gave their hearts to many different women [irogonomi], men who practiced duplicity [futagokoro aru hito], and there were the women who got involved with them, but it seemed to be the rule that in the end the man settled down with one woman. Why should Murasaki herself live in such uncertainty? ${ }^{124}$

This passage reveals the core of the term irogonomi. Stripped of the accoutrements of poetic skill and refinement, the term appears to signify an unbridled sexual impulse directed at multiple objects of desire. Murasaki rejects ada naru otoko, irogonomi, and futagokoro aru hito and attempts instead to remove herself from the world of such men. So too, toward the end of the novel, Ukifune finds herself trapped and driven to utmost despair when she is pursued by two men, Niou and Kaoru. After a failed attempt at suicide, Ukifune retires from the world and becomes a Buddhist nun.

\section{Suki And Artistic Refinement}

Irogonomi becomes an ideal that is celebrated unquestioningly in Ise monogatari-both men and women are engaged in the refined sport of being irogonomi. In Genji, this idealized perception of irogonomi is, on occasion, challenged. Indeed, as ideals, irogonomi and suki are restricted by being confined, for the most part, to men. At the same time, however, the meaning of suki is extended beyond the realm of the sexual. The term acquires much greater flexibility, and, on occasion, suki comes to be associated more directly with excellence in the spheres of poetry and music.

In the "Akashi" chapter, for instance, the father of the lady of Akashi, when pressed by Genji to request his daughter to play the lute, responds:

While we are on the subject of lutes, there were not many even in the old days who could bring out the best in the instrument. Yet it would seem that the person of whom I speak plays with a certain sureness and manages to affect a rather pleasing delicacy. I have no idea where she might have acquired these skills. It seems wrong that she should be asked to compete with the wild waves, but sometimes in my gloom I do have her strike up a tune. ${ }^{125}$ 
The text continues: suki itareba okashi to omoite. Arthur Waley translates this as, "He spoke with so much enthusiasm and discernment"; Edward Seidensticker translates it as, "He spoke with such spirit." ${ }^{26}$ While the theme of Genji's interest in the lady of Akashi and her father's concern to have Genji accept her is never far away, the use of the word suki here, which is translated variously as "discernment" and "spirit," has as much to do with the father's sensitivity to music and its traditions as with his desire to paint an attractive picture of his daughter's musical skills. This becomes clear when we look at what follows:

He spoke with such spirit that Genji, much interested, pushed the lute toward him. He did indeed play beautifully, adding decorations that have gone out of fashion. There was a Chinese elegance in his touch, and he was able to induce a particularly solemn tremolo from the instrument. ${ }^{127}$

In Makura no sōshi (Pillow Book of Sei Shōnagon, eleventh century), Sei Shōnagon, Murasaki Shikibu's contemporary, also uses the word suki in the specific sense of artistic excellence. ${ }^{128}$

The basic associations of the terms suki and irogonomi, as we have seen, were with purely amorous activities. However, these concepts also incorporated other values, such as refinement and sensitivity, and, by extension, skill in poetry and music. In the literature of the Heian period, and particularly in Genji, the scope of the term suki was ever expanding, ranging from the purely sexual to highly refined artistic pursuits. In the highly literate culture to which Murasaki Shikibu and her contemporaries belonged, the range and depth that any word had acquired was explored and played on to its fullest degree. It was assumed that readers who belonged to the same elite circle as the writers would appreciate these nuances and the richness of allusions. A final example from Murasaki Shikibu's diary will help to illustrate this.

Murasaki Shikibu relates that Fujiwara no Michinaga, looking at a copy of Genji that was lying beside the empress, made his usual bantering comments and then wrote a poem on a piece of paper that held some plums:

126. Waley, Genji, 266; TG, 256.

127. GM, 2:233; TG, 256.

128. Matsuo Satoshi and Nagai Kazuko, eds., Makura no sōshi, Nihon koten bungaku zenshū, no. 11 (Tokyo: Shōgakkan, 1974), 90. 


$\begin{array}{ll}\text { Sukimono to } & \text { It is well known } \\ \text { Na ni shi tatereba } & \text { To be a sour fruit, } \\ \text { Miru hito no } & \text { But who could pass } \\ \text { Orade suguru wa } & \text { Or stay his hand } \\ \text { Araji to zo omou } & \text { Who saw such ripeness there? }\end{array}$

Here is an elaborate pun on the word suki, meaning both sour and amorous. An alternative rendering of the same poem could thus be:

As you are renowned

For your amorous ways,

I am sure there are none

Who go by without

Having a taste.

Murasaki Shikibu keeps up the pun and replies:

$\begin{array}{ll}\text { Hito ni mada } & \text { Who is it? } \\ \text { Orarenu mono o } & \text { Who can be so glib } \\ \text { Tare ka kono } & \text { About the reputation } \\ \text { Sukimono zo to wa } & \text { Of a fruit that } \\ \text { Kuchinarashikemu } & \text { Has not yet been tasted? }{ }^{129}\end{array}$

Murasaki is suggesting that since she has not allowed herself to be approached by Michinaga, he is surely in no position to spread the word that she is a woman who offers herself to every man that comes along.

The playful banter, the amorous escapades, and the exchange of clever poems that constituted the world of the sukimonothat is to say, the world of the Heian aristocracy-underwent fundamental changes in the period that followed. The sukimono of this new age came to be a person who was a serious poet or musician, devoted to the norms and traditions of his art. The ideal of the poet and lover gave way to the more somber artist devoted to the Way.

\section{SUKI AND THE WAY OF POETRY}

By the Kamakura period there had occurred a parting of ways between the terms irogonomi and suki, and each term had acquired

129. Fujioka Tadaharu, et al., eds., Murasaki Shikibu nikki, in Izumi Shikibu nikki, Murasaki Shikibu nikki, Sarashina nikki, Sanuki no Suke no nikki, Nihon koten bungaku zenshū, no. 18 (Tokyo: Shōgakkan, 1971), 149-50. Richard Bowring, trans., Murasaki Shikibu: Her Diary and Poetic Memoirs (Princeton: Princeton University Press, 1982), 145. 
greater specificity. Irogonomi, perhaps because of the presence of the word iro (love, sex) within it, came to be separated from its close companion, suki, and relegated more clearly to the realm of sex and love. Conversely, suki came to refer primarily to the realm of artistic activities, and, while it retained a suggestion of its amorous past, it came to signify a single-minded devotion to an artistic pursuit, most often that of poetry or music. The word was now written with substitute characters 数 寄 that were phonetic equivalents (ateji). This may have come about in an attempt to dissociate the word from the amorous connotations embodied in the character 好.

The reasons for this altered signification of suki were closely related to the rise of the ideal of michi in the Kamakura period. As discussed in chapter one, by the Kamakura period, Japanese poetry had gradually become a specialized discipline, a michi, that was to be cultivated by serious poets who made poetry their life's work. The irogonomi of old were nonetheless respected as poets, since their poetry had arisen out of the direct experience of love and all the emotions attendant on it. Moreover, they had the ability to use their poetry in a refined and sensitive manner, as a means of communication between lovers. In Mumyōsho, there is an interesting episode in which the response of the irogonomi of the previous age is upheld as worthy of emulation for poets of the present:

\begin{abstract}
A man once received a letter from a lady in which there were two poems. He was expected to send a reply. The poems in question were, however, two love poems from Kokinshu. There was no way he could reply to these, and turning over in his mind what he ought to do, he sent back two old poems that adequately expressed what he wished to say. When he recounted this to a certain old man, the latter expressed his admiration thus, "That was a splendid thing to do. This is the sort of thing that the irogonomi of olden times would have done. What you did unwittingly was in tune with the conventions of the past and is truly a mark of great refinement." $(M Y, 59)$
\end{abstract}

There is an example of the relationship between irogonomi and michi in Mumyōzōshi (Nameless Book, ca. 1202), one of the earliest critical writings on the monogatari form, the composition of which, of course, had been the prerogative of women in Heian times. The writer-possibly Shunzei's daughter, after she had become a nun-in the course of a discussion on poetry and on the way in which poetic anthologies were put together, remarks: 
From olden times there have been a large number of women who showed great sensitivity and feeling in matters of love [iro o konomi] and who have mastered the Way of Poetry [michi o narau], and yet not a single woman has been the compiler of an anthology of poetry. How extremely regrettable this is. ${ }^{130}$

This statement captures perfectly the loss of power experienced by women, who had played a central role in the development of poetry but found that their literary role had now been appropriated by men. What is significant in the present discussion is the association of the phrase iro o konomi with the notion of poetry as a michi. The connection is not likely to have been fortuitous. For the author of Mumyözōshi, refinement and sensitivity in matters of love, implicit in the old ideal of the irogonomi, coupled with the wholehearted dedication to poetry as a michi resulted in the best poetry. Both in Mumyözöshi and in the above passage from Mumyōsho, irogonomi retains its older sense of sophistication and sensitivity in the amorous sphere. Poetry serves as the gauge by which this refinement can be assessed.

The word suki no longer conjured up the ideal of amorous pursuits, consummated through (among other things) the composition of elegant verse. Suki in the Kamakura period came to be appropriated by the dominant cultural ideal of the period, michi. The sukimono was now a person with a deep commitment to the pursuit of a michi, particularly that of poetry.

In the collection of poetic lore called Fukurozōshi (Notes in a Folder), written by the famous poet Fujiwara no Kiyosuke in 1158 , suki appears in precisely this altered sense. Kiyosuke praises the poets of earlier times: "The great poets of old gave themselves up totally to poetry [furuki kasen wa mina sukeru nari]." He recounts how the poet-priest Nōin (987-1058) used to advise wouldbe poets, saying, "One must work hard at poetry. It is through total devotion to the art that poems of an excellent quality can be composed [suki tamae, sukinureba shūka wa yomu zo]." ${ }^{131}$

130. Kuwabara Hiroshi, ed., Mumyōzōshi, Shinchō Nihon koten shūsei (Tokyo: Shinchōsha, 1976), 105. See also Michele Marra, trans., "Mumyōzōshi: Introduction and Translation," Monumenta Nipponica 39.2 (summer 1984): 115-45; 39.3 (autumn 1984): 281-305; 39.4 (winter 1984): 409-34.

131. Ozawa Masao, ed., Fukurozōshi chūshaku, vol. 1 (Tokyo: Hanawa Shobō, 1973), 263-64. 
So too in a collection of poetic lore called Saigyō shōnin dansho (The Recollections of the Priest Saigyō), attributed to the poet Saigyō and written down by his pupil Ren'a sometime between 1225 and 1229 , the quality of suki is identified as central to poetic composition:

Japanese poetry is the well-spring of suki. One must compose poetry only after having devoted oneself totally to it [kokoro no sukite yomu beki nari]. The chief priest of the Great Ise Shrine should devote himself with a pure heart to the cultivation of poetry [kokoro kiyoku sukite waka o konomu beki nari]. This would certainly please the goddess Amaterasu. ${ }^{132}$

The development of waka as a michi in the twelfth century gave birth to a host of works on waka poetics. These works were less concerned with pure theory and concentrated more on stories and anecdotes illustrating Japanese poetic traditions and folklore. These treatises were meant as guides for poets who intended to follow the way of poetry (waka no michi). In practical terms, this meant providing would-be poets with the know-how to win poetry contests and get their poems accepted into prestigious anthologies.

Shunrai (Minamoto no Toshiyori) and Fujiwara no Mototoshi, who were leading poets, wrote treatises on poetry: Shunrai's Shunpishō (Secret Notes by Shunrai), compiled in the years 111415; and Mototoshi's Etsumokushō (Notes to Gladden the Heart), which no longer survives. These two works, along with Kiyosuke's Fukurozosshi, were representative of those that focused on ancient poetic practices and matters of precedent as well as on the proper ways in which to interpret waka.

What marked the poetic treatises of the twelfth century was a self-conscious and sustained attempt by waka practitioners to create a formal tradition for Japanese poetry. By harking back to the great works of the past, Man'yōshü, Kokinshū, and the poetry of China, poets created models that could be considered worthy of emulation and that could provide their own poetic efforts with a certain legitimizing force. The growing sanctity of the poetic practices of the past led to the establishment of a kind of classicism; only forms of expression modeled on those perfected in the past were recognized as having lasting value.

132. Hisamatsu Sen'ichi, ed., Saigyō shōnin danshō, in Karonshū, vol. 1, Chūsei no bungaku (Tokyo: Miai Shoten, 1971), 107. 
It is worth noting that the lamentation of the decadence of the present and the adulation of the past were features of the earliest Heian texts. In the Japanese preface to Kokinshü, for example, Ki no Tsurayuki wrote of the vigor of ancient poetry, as represented by Man'yōshū, and lamented that in his age "only surface brilliance is valued, people's hearts have grown frivolous" and "they produce nought but frothy poems, inconsequential words." The golden age, evoked in works such as Kokinshu and Ise monogatari, represents a nostalgia for a past that is gone.

The twelfth-century idealization of the poetry of the past was, however, notably different from that found in the literary works of the tenth and eleventh centuries. Waka poets now engaged in a systematic documentation of the poetic practices of the past and read into them such meaning as would strengthen their claim that waka practice constituted a michi, thus enabling them to valorize a vocation that brought with it prestige and success at court. This documentation found expression in the diverse compendiums that are a feature of this period. The diaries that the nobility left behind, as well as collections of ancient practices (kojitsu) like Unzushō, bear testimony to this new concern. ${ }^{133}$ Popular songs were collected for the first time, and this resulted in the compilation of Ryōjin hishō. ${ }^{134}$ Collections of popular tales (setsuwa), many relating to poetry, music, and other artistic pursuits, flourished in this period.

In every sphere of literary activity the cumulative knowledge of the past was recorded as the necessary foundation for future literary efforts. In Korai füteishū, for example, the poet Shunzei asserted that if one wished to be a good poet, it was enough to venerate and trust Kokinshü because it represented the ideal form of poetry. ${ }^{135} \mathrm{He}$ claimed that it was in the period when Kokinshu was compiled that what was good and bad in poetry was first discerned, and that Kokinshu was the first anthology compiled according to set rules. It included only what was good. In a similar vein was Shunzei's famous statement, "A poet who has not read

133. Unzushō was a work by Fujiwara no Shigetaka, written between the years 1115 and 1118 , in which he recorded ancient court practices.

134. This was a collection of popular songs (imayo) compiled by the emperor Go-Shirakawa (1 127-92).

135. Hisamatsu, Korai füteishō, 288. 
Genji monogatari is a sorry poet indeed." ${ }^{36}$ Practices that lacked precedence were rarely accepted, and the word new never lost its strongly derogatory connotations.

Another example of this project of creating a tradition for waka was the compilation and categorization of poetic place-names (utamakura) used in waka. Clearly, not all place-names constituted utamakura; only places prominent in history or legend could produce the rich associations that would enhance a waka. Medieval waka poets were expected to have a mastery of utamakura. This meant knowledge of the poetry in which utamakura had appeared as well as of the legends associated with them. A work attributed to Nōin, Nōin utamakura, for example, was a compendium of poetic place-names that waka poets could use in their own compositions.

To lend further authenticity to utamakura, there arose a body of myths about poets who went beyond the memorization of poetic place-names and actually undertook arduous travel to gain direct experience of places that had become enshrined in poetry. Thus travel (tabi) became a significant motif in the quest to find, record, and re-create poetic tradition. Both the poets Noin and Saigyo were credited with having made such journeys. There is evidence to suggest that practical business considerations prompted these journeys rather than purely the commitment to poetry. ${ }^{137}$ What is interesting, however, is that legends of the past were reworked by the twelfth-century poets to supply for waka the tradition it needed to be established as a michi.

\section{Suki AND the Way of Poetry in Mumyōshō}

It is within this context that Kamo no Chōmei wrote Mumyōshō, a blend of poetic theory (karon) and anecdotes of the kind that appear in other setsuwa collections of that period. His discussion of the poetic ideal of yūgen (profundity, mystery) in Mumyōshō has justly received considerable attention from scholars. Poetics per se, however, is by no means the sole focus of Mumyōshō. A considerable portion of the text is devoted to recounting tales about poets and priests who display a single-minded devotion to poetry and as a result obtain a measure of fame and success.

136. Hagitani Boku and Tamiyama Shigeru, eds., Utaawaseshū, Nihon koten bungaku taikei, no. 74 (Tokyo: Iwanami Shoten, 1965), 442.

137. See Konishi Jin'ichi, A History of Japanese Literature, vol. 3 (Princeton: Princeton University Press, 1991), 36. 
In Mumyōshö the ideal poet is invariably a person who respects the "ancient" traditions of waka and has considerable knowledge of them. We can identify several key words around which Chōmei develops his vision of the exemplary poet, and suki is central to the formulation of this vision. This is the theme taken up in the rest of the chapter. I do not attempt a comprehensive textual exegesis of Mumyōshō but rather examine how, by spelling out the particular qualities and the training necessary to become a sukimono, Chōmei presents a kind of manual for those poets who intend to devote themselves seriously to the way of poetry.

\section{Kojitsu (Ancient Practices and Customs)}

In Mumyōshō Chōmei writes that Shun'e emphasized to him the importance of the traditional practices (kojitsu) after they had tied the intimate bond of the master-pupil relationship (see p. 69). Going on to illustrate what he meant, Shun'e spoke about the minister of Gotokudaiji, Sanesada:

He used to be a poet who was without peer, but he showed
no consideration for ancient practices [kojitsu], and thus
he fell behind. If he had continued the way he had been
when he was the ex-great chancellor, showing total at-
tachment to the way of poetry, behaving with modesty
and refining his work, there would be few poets today
who could compare with him. However, he now believes
that he has mastered the way; the poems that he com-
poses these days are written without any concentration
and are interspersed with words that are hardly worthy
of appreciation. How then can he expect to compose ex-
cellent poetry?

This passage is instructive for all that it tells us about the qualities that Chōmei considered fundamental to writing good poetry. Above all, poets were expected to treat ancient practices with the utmost seriousness. Sanesada's disregard for precedent, his use of "words that are hardly worthy of appreciation," that is, words not sanctioned by the past masters, accounted for his lack of success as a poet. Speaking of people's favorable assessment of his own work, Shun'e attributes his success to his strict adherence to ancient practices:

Even now, when I compose a poem, I do so in the same spirit as when I first began writing poetry. Also, I give my own feelings second place and put my trust in other 
people's evaluation of my work, even when what they say seems dubious to me. This has been the teaching of the poets of old. I wonder if it is because of this that, although I have reached old age, there is no one who has so far said that I am not a good poet. I do believe that the reason for this is none other than the fact that I have never violated ancient practices [kojitsu]. (MY, 68-69)

\section{Hon'i and Dai}

'The poetic concept of hon'i became a central part of the critical judgments of utaawase (poetry contests) from the beginning of the eleventh century. The term referred to correct handling of a given topic, decorum of feeling, the conventional treatment of an image, and the real significance of an experience. There was now a fixed, predetermined interpretation of each topic (dai). The topic itself came to be more rigidly specified, and there was a marked increase in the twelfth century of poems on assigned topics rather than on actual scenes that poets encountered. ${ }^{138}$ While there was disagreement between Teika and the more conservative poets, such as the cloistered emperor Go-Toba, about what was meant by "correct handling," there was a consensus that only subjects and expressions sanctioned by the tradition were acceptable. As Brower and Miner write,

There may well have been misanthropes in the Japanese court who hated both man and nature, but if they were poets, the "decorum of feeling" associated with cherry blossoms required that in poetry they express impatience in waiting for their blooming, delight in their beauty, and distress at their falling. To have treated such a subject in any other way would only have stamped the poet as an ignorant boor or at best a jokester. ${ }^{139}$

In Mumyōshō, Chōmei speaks of the importance of adhering to the spirit or real significance of a topic. This, he suggests, can be done only by paying due regard to ancient practices:

Now, in order to make sure that we handle the dai of a particular poem with the deepest care, we must under-

138. For a detailed discussion on hon'i and dai, see Konishi, Japanese Literature, vol, 3, 38-44, 194-96.

139. Robert H. Brower and Earl Miner, Japanese Court Poetry (Stanford: Stanford University Press, 1961), 254. 
stand well the kinds of things that were never said in the poetry of old. For instance, when we compose a poem on the cuckoo, we speak in terms of going out into the mountains in search of its voice. In the case of the bush warbler, poetic practice allows us to talk in terms of waiting for it, but we cannot speak of going out in search of it. In a similar way, in poetry, when we hear the cry of the deer, we speak of the feeling of forlornness and pathos it arouses in us, but we do not speak of waiting for the cry of the deer. Except for the sake of a particularly brilliant phrase, this kind of thing should be avoided at all costs. Again, we go out to see the cherry trees but not the willows; we make poems about waiting for the first snow, but not about waiting for the drizzle or hail. Although we speak in poetry of being so attached to cherry blossoms that we would even give up our lives rather than see them scatter, we do not go so far with the red maple leaves of autumn. If you do not know these things, it will appear as though you are ignorant of ancient practices [kojitsu]. Therefore, when you plan the composition of a poem, you should do so on the basis of a careful study of old poems and the nature of the poem itself. (MY, 37-38)

\section{Rediscovering Objects and Places with Poetic Associations (Utamakura)}

For Chōmei, upholding the past meant the idealization of earlier poets as being truly dedicated to their art. These poets were held up as the perfect sukimono. As we have seen earlier, the poets of the Heian period were irogonomi or sukimono in a rather different sense. For them, poetry was an important part of a life of refinement and grace, but total devotion to one artistic pursuit was by no means part of the ideal life conceived by the courtiers of that period. Ironically, the glorification of the past meant the attribution of the new ideal of suki-total commitment to the way of poetry-to the poets of the past. Chomei presented suki as the recovery of a lost ideal, when in fact what he and others were doing was undertaking a substantial redefinition of it.

There are many instances in Mumyōshō where Chōmei laments the present and eulogizes the poetic practices of the past. For instance, when he speaks out against the poetry contests of his times, he criticizes their disorderliness and derides the poets for their arrogance and their lack of respect for the masters of poetry. Chomei explains this decadence in terms of the lack of suki among his contemporaries: "The reason for this is that people no longer feel a sense of deep commitment to the way of poetry but 
merely dabble in the art in emulation of others [kokoro no soko made sukazu shite, tada hito mane ni michi o konomu ga yue nanmeri]" (MY, 71).

This is, of course, precisely the charge that, according to Chōmei, Shun'e had laid against Sanesada. Poets of Chōmei's day could hope to approximate the ideals of the past only through rigorous self-discipline and a self-conscious commitment to the way of poetry. Throughout Mumyōshō, Chōmei recounts tales about the sukimono he admires, and in doing so he spells out the qualities and practices that make a poet worthy of being called a sukimono.

One of the great quests of the sukimono, idealized by Chōmei, was to view in person the natural phenomena and places that had been used as images in collections like Man'yōshū and Kokinsh $\bar{u}$. The assumption was that these images were once immediate and real for the poet who evoked them, but that in the course of time they had become remote and abstract because the places and objects they referred to were no longer part of the poet's own experience. For the ideal poet, therefore, a visit to places rich in poetic associations (utamakura) came to be considered vital in order to use these phrases in an authentic manner.

In Mumyōshō, Chōmei recounts the story about the sukimono priest Tören. A group of people, in the course of discussing things of olden days, began to talk about a grass called masuo no susuki. No one was sure about the exact nature of this plant. One of the men recalled that he had heard of a holy man in Watanobe who knew what this particular grass looked like. The priest Tōren, who happened to be present, immediately asked the host for a straw raincoat and hat and decided to leave without a word, undeterred by the heavy rain.

When his friends asked him where he was going, he explained that he had to go to Watanobe immediately to meet the holy man who could enlighten him on the subject of masuo no susuki, a matter that had been troubling him for years. His friends tried to dissuade him from setting out in the rain, but he dismissed their suggestions, saying, "Is it certain that either the holy man or I will live until the rains stop?" We are told that Tōren was thus able to fulfill his personal desire to discover the true nature of masuo no susuki and that he cherished this knowledge as his secret treasure, passing it on to his disciples. Chōmei praises Tōren, saying, "He was truly a man who was totally devoted to poetry 
[imijikarikeru sukimono nari]." He explains that masuo no susuki was a phrase used by the poet Lord Toshiyori and that, although it could not be ascertained whether or not it had appeared in Kokin$s h \bar{u}$, in the discipline of poetry it was common practice to use such old phrases (furugoto). People no longer knew exactly what these old names referred to. It is in this context that Tōren's complete devotion to the art of poetry, which drove him to find out about the true nature of masuo no susuki, is exceptional, and it is this quality that Chōmei valorizes in what he calls the sukimono (MY, 48-49).

Chōmei narrates another story about a man who visited a place called Ide, met an old man there, and got to talking about the things of old. The traveler asked the old man why the yellow roses of Ide, which were so famous in Japanese poetry, were nowhere to be seen. The old man explained that the local people (oblivious to the poetic significance of the plant) had pulled them out and mixed them into the soil in the belief that this would produce a better rice crop. He pointed out that Ide was also known for a kind of frog found only in the lde River, and that this kawazu was different from other frogs in that it was darker, lived in the water, and did not hop around openly on land. Above all, the plaintive quality of its voice, heard in the deep of the night, had a very soothing effect on the mind. The old man urged the visitor to come again without fail in the spring or the summer to listen to the cry of the kawazu.

Chōmei goes on to say that despite this story, he himself had not made the time to go and visit Ide. He laments the fact that his own dedication to poetry falls short of that shown by the priest Tōren:

\footnotetext{
When I think of this, I feel that in the days to come there will be very few people who, even if some business were to take them to such a place, would care to listen to such sounds as the cry of the kawazu. This is because with the passage of time people's devotion to art [suki] and their sensibilities [nasake] have undergone a decline. (MY, 49-51)
}

The poetic lore of the period is full of stories that indicate the high value placed on places and objects with poetic associations. As with the yellow rose and the frog of Ide, which were valued for their rarity, so too the bridge of Nagara, one of the oldest 
constructions in Japan, had come to be valued for its age. But even more, the repeated appearance of these objects in the poetry of the past rendered them venerable. ${ }^{140}$

Sacrificing One's Life for the Way of Poetry

Devotion to the way of poetry was judged not only by adherence to poetic precedent but also by a poet's determination to put aside practical considerations in the struggle to perfect the art. Sacrificing one's life on the altar of poetry was the pinnacle of this dedication, and many hagiographies in setsuwa collections recount instances of poets giving up their lives for their art. In a story in Mumyōshō entitled "Yorizane no suki," Chōmei recounts how the great sukimono Yorizane offered five years of his life to the god of Sumiyoshi in exchange for the ability to compose one outstanding poem. Later, when Yorizane was taken seriously ill, the god possessed one of the ladies in his house and explained that he had let Yorizane compose a poem of very high quality. Yorizane did not recover from this illness, as the god now claimed the five years (MY, 95-96).

Mumyōshō also recounts the story of the Lady Kunaikyō, who used to forget everything else when she was composing poems, often working day and night without a break. "This person reflected too deeply on poetry and as a result fell ill. At one time she was even on the verge of death because of this." Her father

140. In one story in Fukurozōshi, the poet Sesshin, described as a sukimono, meets the priest Nōin, another great poet. The two establish an immediate rapport, and Nōin offers Sesshin a gift on the occasion of their first meeting. It is a wood shaving. Noin explains that it is his most treasured belonging-a relic of the construction of the bridge of Nagara. Sesshin is delighted with the gift and in return offers Nōin something wrapped in a piece of paper. When Nōin opens it, he finds a dried frog, none other than the famous kawazu of Ide. We are told that both of them were deeply moved, and, armed with their priceless gifts, they parted company. See Ozawa, Fukurozöshi chūshaku, 263. Uji shüi monogatari tells the story of the priest Yōen, who was invited to a Buddhist service and there presented with a fragment of wood from the bridge of Nagara. The next day, the holy teacher Kakuen visited him and asked him for it, acknowledging that Yón would not want to part with such a treasure. The narrator concludes, "It is indeed moving to see such devotion to the arts [sukizukishiku aware naru koto domo nari]." See Kobayashi Tomoaki, ed., Uji shũi monogatari, Nihon koten bungaku zenshū, no. 28 (Tokyo: Shōgakkan, 1973), 149. 
admonished her, saying that everything she did had meaning only if she stayed healthy, and that there was no point in working so hard at poetry that it made her lose her good health. But his counsel proved to be of no avail: we are told that when her death came, it was probably a result of her overexertion in the pursuit of poetic excellence. Kunaikyō was greatly admired for this by the poet Jakuren, who lamented the fact that Kunaikyō's brother, by contrast, took poetry so lightly (uta ni kokoro o irenu; $M Y, 77$ ).

Fukurozōshi recounts the story of Fujiwara no Nagatō, who, when asked to compose a poem on the topic "The Passing of Spring" (sangatsujin) at the palace of the cloistered emperor Kazan, wrote,

Kokoro uki

Toshi ni mo aru ka na

Hatsuka amari

Kokonuka to iu ni

Haru no kurenuru
This year

Is indeed a cruel one.

As the third month

Has but twenty-nine days

Spring has passed already.

When the poet Fujiwara no Kintō heard the poem, he is said to have retorted, "Do you think spring has thirty days?" His criticism appears to have stemmed from the fact that Nagato had not stuck closely enough to the topic. Instead of focusing on the idea of the passing of spring, Nagato had turned his attention to the shortness of the third month that year (twenty-nine days instead of thirty). Kintō's criticism had such a serious effect on Nagatō that he fell ill, and when Kintō inquired after him, Nagatō explained that his illness was a direct result of Kintō's criticism of his poem. Indeed, Nagato died shortly afterward. The story concludes with the admonition, "One must not thoughtlessly criticize the poetry of people who are so totally committed to their art."141

Whether or not Lady Kunaikyō really did die on account of the sleepless nights spent in composing poetry, or Fujiwara no Nagato as a result of his deep feeling of humiliation, the above stories indicate how the relationship of the poet to the poetic art came to be constructed. Dedication to poetry came to be represented as transcending the love for life itself.

\section{The Way of Poetry: A Spiritual and Worldly Ideal}

The definition of poetry as a michi, and the degree of commitment now required to prove one's devotion to it, perforce carried this art 
into a realm that was otherworldly. There developed the image of the perfect poet, who took no interest in his material surroundings and was willing to sacrifice even his life for the sake of poetry. A fifteenth-century treatise by the poet Shinkei, Sasamegoto (Murmured Conversations), recounts how Teika admonished his son Tameie for his uncaring attitude toward poetry and related to him the way in which his own father, Shunzei, composed his poems:

Very late at night, he would sit by his bed in front of an oil lamp so dim that it was difficult to tell whether it was burning or not, and with a tattered court robe thrown over his shoulders and an old court cap pulled down to his ears, he would lean on an armrest, hugging a wooden brazier for warmth while he recited verse to himself in an undertone. Deep into the night when everyone else was asleep, he would sit there bent over, weeping softly. . . . ${ }^{142}$

What emerges is not only Shunzei's complete involvement with poetry, but also his total disregard for material comforts.

Such is also the case with the poet Yorimasa, whom Chömei's teacher Shun'e praised in Mumyōshō:

Lord Yorimasa is a great poetic genius. He is wholly absorbed in poetry, and not a moment goes by when he does not think about it-when the cherry blossoms scatter or the autumn leaves fall, even at the mere crying of a bird or the rustling of the wind. No matter whether he is up or lying down, Lord Yorimasa does not fail to turn over in his mind all that he sees and feels and to conceptualize it in poetic terms. It is for this reason, I believe, that he composes verses of such exceptional quality. (MY, 72)

Poetry as a michi was at once spiritual and worldly. The utmost value was placed in composing good poetry, and the excellence of a particular composition could be judged only by other practitioners in the field. Poets could measure the worth of their poems only by their inclusion in prestigious anthologies and through poetry contests. The leading court poets expected to see their devotion rewarded through success on the worldly plane. The sukimono that Chōmei idealizes in Mumyōshō are deeply devoted to poetry; equally, they are men and women who wish to be recognized, to be immortalized through their poetry. 
This desire to be remembered forever for one's poetry was seen as an index of poets' deep involvement with their art. The story of the lay priest Dōin in Mumyōshō is an account of a man's unmatched devotion to poetry. Until the age of eighty, Dōin would go on foot every month to the Sumiyoshi shrine and pray to the gods to help him compose the very best poetry. In a certain poetry contest in which Fujiwara no Kiyosuke (the compiler of Fukurozōshi) was judge, Dōin's poem was declared a loser. At this, he made his way up to the judge and, weeping quite openly, complained about the decision. Kiyosuke was at a loss as to how to respond and, later, recounting the incident, professed that he had never before encountered anyone who had taken the matter so seriously.

When Dōin was in his nineties, he used to attend poetry contests and draw up close to the judge, presumably because he was now hard of hearing. As Chōmei says, "The sight of this incredibly old man listening with intense concentration was extremely impressive." Although the poetry anthology Senzaishū was compiled after Dōin's death, Shunzei included eighteen of his poems as a tribute to a man who had shown such devotion to the way of poetry. Dōin then appeared to Shunzei in a dream and shed tears of gratitude at the honor of being immortalized through his poetry. This dream touched Shunzei deeply, and he added two more of Dōin's poems to the anthology ( $M Y, 74-75)$.

There are several anecdotes in Mumyōsho that reveal the practical underside of the way of poetry. Chömei, for example, is offered some worldly advice by Nakahara no Ariyasu, his music teacher:

Since you have shown talent in the discipline of poetry, you will undoubtedly be invited with some insistence to attend poetry gatherings in all kinds of places. If you compose good poems on such occasions, you will probably receive both honor and fame. But while that might well be the case, if you were to go to all sorts of places, flattering people and being treated with extreme familiarity by others, you will certainly be well known in the realm of poetry, but it cannot fail to be an impediment to your advancement. For a person like you, it would be best if you did not make yourself too well known to people. Then wherever you went people would ask, "I wonder who that gentleman is?" and this would lead to your being considered a man of great refinement. If one applies oneself to something, one is bound to excel in that discipline, and in that case such talents will not go unnoticed. People 
will hear of them and you will get to attend poetry gatherings of consequence-you might even be able to take a seat behind the highest-ranking nobility. This would be real advancement in the way [of poetry]. What possible value can there be in mixing with people who are of no consequence and being well known in such circles? ( $M Y$, 45-46)

Real advancement in the way of poetry for Ariyasu is being accepted in the highest echelons of the nobility as a poet of consequence. ${ }^{143}$ Success among people of low status does not count for much in his eyes. Implicit in Ariyasu's advice to Chomei is the belief that only an outstanding poet would have access to the poetry gatherings of the highest-ranking nobility. Poetic excellence and worldly recognition were inseparable. By definition, a good poet was one who was recognized as such and duly rewarded by the emperor and notables of the court, people who were not only poets themselves but also the patrons of poetic activities.

In Mumyōsho, Chōmei speaks of his extreme pleasure at having one of his poems included in $\operatorname{Senzaishu}(M Y, 45$; see p. 70$)$, and he expressed the same sense of delight when his poem with the controversial phrase semi no ogawa got the recognition it deserved and was included in Shinkokinshü.

Poetic excellence meant the pursuit of poetry as a michi. This involved selfless dedication and concentration and treating the practice of poetry as identical with the pursuit of the Buddha's dharma. This understanding of poetry lifted it to a realm that was spiritual or, at any rate, unworldly. Success, however, rested squarely in the realm of the material, of the worldly. This contradiction is not overtly articulated in Mumyōshō.

The poets who are described as sukimono in Mumyōshō, while inhabiting the courtly world, stand out precisely because of their apparent unawareness of that world, so absorbed are they in poetry. Yorimasa (who turns over in his mind all that he sees and feels and translates it into the language of poetry), Yorizane (who sacrifices his life for one outstanding composition), and Tören (who braves inclement weather to discover the provenance of masuo no susuki) are examples of this.

143. Interestingly enough, the term for advancement used here, sento, is the term used within court society to describe the advancement of members of the court nobility to the highest official posts on the basis of their family rank and status. 
However, the priest Dōin is presented as being no less laudable for wanting his poems to be included in Senzaishu and for complaining bitterly to the judge who fails to assess his poems favorably. His desire to succeed is a further gauge of his deep devotion to poetry.

There are hints within Mumyōshō that Chōmei does recognize the contradictory pulls on the poet; it is in this context that we can read Chōmei's response to his own poetic achievements. Reflecting on the inclusion of his poems, including the one containing the phrase semi no ogawa, in Shinkokinshü, Chōmei remarks, "This was an honor that went far beyond what I deserved. Among all these poems, the inclusion of this particular poem brought me such happiness as to be a hindrance even in future lives. And yet, alas, how worthless all this is laware mueki na koto ka na]!" (MY, 43-45).

This tension provides the possibility of multiple readings of some of the anecdotes within the text. One story in Mumyōshō is particularly worthy of discussion in this regard. The poet Toshiyori heard some entertainers (kugutsu) singing songs. ${ }^{144}$ Among these was a poem composed by Toshiyori himself. Hearing them, Toshiyori remarked, "Toshiyori, you've arrived [Toshiyori itari sōrainikeri nal!" The bishop Eien, hearing of Toshiyori's experience, felt so envious that he offered some blind minstrels (biwa hoshi) various presents to recite a poem of his in several places. His contemporaries remarked that Eien had shown a devotion to his art rarely to be seen in anyone (arigataki sukibito). The poet Atsuyori, hearing of these events, felt so jealous that he seized some blind people and forced them to sing his songs without giving them anything. Chömei explains that Atsuyori became the laughingstock of the world $(M Y, 55)$.

In his stimulating reading of Chōmei and his texts, Thomas Hare suggests that in Mumyōshō Chōmei engages in a cynical assessment of the world of poetry and that "his experience of the social context of poetry in late Heian is soured by the petty controversies and jealousies of prominent poets." A great deal of his argument rests on the anecdote recounted above. Hare suggests that this anecdote can be read ironically and that it contains

144. Kugutsu were groups of itinerant entertainers who sang songs, recited poetry, and staged puppet plays. The female members often functioned also as prostitutes. 
within it Chomei's criticism of the fact that "poetic achievement is a matter of reputation rather than imagination." 145

If, however, one acknowledges that "reputation" and "imagination" are inextricably interwoven in the medieval conception of the ideal poet, then it becomes less easy to confirm the irony Hare describes. Chomei recounts several other incidents involving the poet Toshiyori, a rival of his contemporary Mototoshi. In one anecdote in Mumyōshö, Mototoshi, who is judge at a poetry contest, fails Toshiyori's poem because he mistakenly interprets the word tatsu to mean cranes. Toshiyori later quietly points out that he had used the term tatsu to mean dragons. Chômei comments that while Mototoshi was a man of talent, he had the habit of judging matters too hastily and thus making mistakes. Toshiyori emerges in many of the anecdotes as a poet with a sense of humor and an acerbic tongue, but his poetic judgment is praised in the highest terms.

When we consider, moreover, that Toshiyori was the teacher of Shun'e, who in turn was Chomei's mentor and teacher, it becomes even less likely that Chomei is being critical of Toshiyori's proclamation that he has arrived. Toshiyori's poetry drew freely on what Konishi Jin'ichi calls zoku (low) expression, which in a limited way became an important feature of twelfth-century waka. ${ }^{146}$ Thus colloquial language appears frequently in Toshiyori's renga. It is therefore perhaps not that surprising that, in the anecdote in question, one of Toshiyori's poems is recited by the itinerant singer and that this touches his vanity. ${ }^{147}$

Bishop Eien, who pays biwa hōshi to recite his poem, is described as an arigataki sukibito. In both Mumyōshō and Hosshinshū, Chōmei assigns only positive attributes to the ideal of suki. There is therefore no precedent for reading this term in a manner that would suggest criticism of Eien. Buying the privilege

145. Hare, "Reading Kamo no Chōmei," 227.

146. Konishi, History of Japanese Literature, 3:68.

147. In this context Hare asks, with skepticism, "Was it, in the early twelfth century, something to be proud of to have one's poetry sung before an official of the highest public office by itinerant performers who doubled up as prostitutes? Did Shunrai himself think so? And did Chōmei agree?" See Hare, "Reading Kamo no Chōmei," 184-85. Perhaps if we recognize that the refined world of the court did intersect with the more lowbrow world of itinerant entertainment la phenomenon that some centuries later gave birth to Noh theater), and that the two did not occupy mutually exclusive worlds, it becomes possible to imagine Toshiyori feeling pleased with himself for becoming a "popular" poet. 
of having one's poems sung by minstrels was not looked upon as in any way unethical. Eien acknowledged Toshiyori's achievement, and, wishing to emulate him, he paid some minstrels for their services. ${ }^{148}$

It is worth recounting here another story from Kokon chomonjū (A Collection of Notable Tales Old and New, ca. 1254). The poet-priest Nōin composes a poem in which he uses the utamakura Shirakawa no seki (the barrier at Shirakawa). However, he has not left the capital. Instead he hides away in his house and secretly exposes himself to wind and sun to acquire a tan. He then makes public his poem, with a headnote saying that it was composed in the course of performing religious rites in Michinoku. For this, the compiler of Kokon chomonjü describes Nōin as a sukimono beyond compare. Nōin's conduct is not interpreted as deceitful or hypocritical. It is presumably Nōin's understanding of the spirit that lies behind the journeys to famous utamakura, and of the symbolic power of such journeys, the effect of which he simulates in his own garden, that makes him worthy of the highest praise. ${ }^{149}$ So too, Eien's payment of biwa hōshi can be read as an index of his unparalleled dedication to his art.

The last figure in this anecdote in Mumyōsho is the lay priest Atsuyori. Echoing as he does Eien's sentiments, his desire to have his poems recited by musicians is in no way reprehensible. It is the manner in which he seeks to accomplish this desire, namely, by forcing blind people to recite his poems without paying them anything, that makes it unacceptable. The use of means not sanctioned by precedent-his Iack of refinement-makes Atsuyori the laughingstock of the world. Clearly he does not remain so for long, for the same Atsuyori later becomes the venerable old priest Dōin, mentioned earlier, who shows obsessive devotion to poetry and to poetic success. ${ }^{150}$

148. One might mention here that in music, too, the privilege of learning one of the secret melodies depended not only on the pupil's progress but also on his ability to buy an appropriate present for the master. See Iso Mizue, "Biwa hikkyoku denjū sahō no seiritsu to haikei," Tōyō ongaku kenkyū 48 (1982): 5-41.

149. Nagazumi Yasuaki and Shimada Isao, eds., Kokon chomonjū, Nihon koten bungaku taikei, no. 84, 10th ed. (Tokyo: Iwanami shoten, 1977), 158.

150. The lay priest Atsuyori reappears in Mumyōshō as the venerable priest Dōin, who is singularly devoted to poetry-a point overlooked by Hare. 
Thus, it can be argued that while Mumyōshō does hint at a sense of unease regarding the worldly aspects of waka practice, it does not attempt to break out of the contradiction inherent to the concept of michi, namely, that it is at once a worldly as well as a spiritual ideal. Mumyōshō does not question the value of composing poetry, nor does it claim that it is an expedient means or that it is identical with the way of the Buddha. The work functions as a discourse on poetry as michi. By interpreting and re-creating the poetic traditions of the past, it seeks to valorize the practice of poetry. In spite of the attempts to portray sukimono as being totally oblivious to the material world, there is no escaping the fact that in Mumyōshō sukimono are situated within the world of the court, where they expect to see their dedication to poetry rewarded.

\section{WAKa as ATtachment}

A fourteenth-century assessment of waka by the great master of renga Nijô Yoshimoto (1320-88) highlights the ways in which attachment is integral to waka as michi. In Tsukuba mondō (The Tsukuba Dialogues), which is composed in the form of questions and answers, Yoshimoto, when asked whether renga could be a means to enlightenment, responds in the affirmative and proceeds to point out some basic differences between waka and renga:

Renga do not carry over to the future an idea conceived in a previous moment. In renga, success and failure, joy and sorrow replace and succeed one another, and in this way renga follow the course of this fleeting world. Even as one thinks of yesterday, today is gone; when one thinks of spring, it is already autumn; and while one is thinking of cherry blossoms, they have already become the autumn leaves. Is this not the same as meditating on the ephemerality of this world? In the past people showed too much attachment to the way of poetry, and there are examples of a poet who exchanged his life for one verse or of the poet who died because he could not endure the criticism his poem had received. ${ }^{151}$ This is not the case with renga. ... In renga, one simply enjoys the pleasure of composing for that moment, and thus there is no question of having a mind steeped in attachment. ${ }^{152}$

151. This is a reference to the poet Yorizane, whom Chomei speaks about in Mumyōsho, and the poet Fujiwara no Nagatō, who appears in Fukurozōshi, quoted earlier.

152. Kidō Saizō and Imoto Nōichi, eds., Tsukuba mondō, in Rengaronshü, Haironshü, Nihon koten bungaku taikei, no. 66 (Tokyo: Iwanami Shoten, 1961), 82-83. 
For Yoshimoto, the major problem with waka poets was their fierce commitment to the composition of particular poems, the success or failure of which could sometimes be a matter of life and death. However, renga masters, he claimed, were concerned only with the fleeting moment. They gave no consideration to a previous thought or to what was to follow but simply produced the next phrase on the basis of the phrase before their eyes. The very form of renga was more in tune with the essentially changing and evanescent nature of the world and hence free from the problem of attachment. Yoshimoto undoubtedly constructs a highly idealized picture of renga practice. What is interesting here is that in his polemic he is able to make a special claim for renga by criticizing the practice of waka on the grounds that it is deeply embroiled in worldly attachments.

Mumyōshō does not acknowledge directly the contradiction between attachment and detachment that lies at the heart of the ideal of michi. It is in Chōmei's collection of religious tales, Hosshin$s h \bar{u}$, that these issues take on considerable significance. In Hosshinshü, the sukimono, who in Mumyōshō are unavoidably implicated in court society, are relocated in the world of renunciation. They become Buddhist recluses, for whom the spiritual goals of Buddhism are of paramount importance. In this new setting, the worldly aspects associated with the sukimono in Mumyōshō have to be negotiated, and only those elements of suki that are clearly linked with otherworldliness are highlighted. In the chapter that follows, I argue that there is a shift in emphasis in the use of the term suki in Chōmei's religious work, which represents an attempt to grapple with the worldly aspect of suki. What results is a redefinition of poetry and of the sukimono who devote themselves to it. 


\title{
Chapter Four
}

\author{
Suki and the Attainment of \\ Religious Awakening: Hosshinsh $\bar{u}$
}

In Chömei's poetic treatise, Mumyōshō, ideal sukimono devoted their entire lives to the pursuit of poetry and were active participants in the poetic activities of the court, for it was only there that they could make their mark as poets worthy of acclaim. In Mumy $\bar{o}-$ sho, then, two elements-total absorption in poetry and the desire to see this dedication recognized and rewarded-are integral to the qualities of the ideal sukimono.

In contrast, the explicit separation and, indeed, polarization of these two urges occurs in Chōmei's Hosshinshū, a collection of Buddhist setsuwa, exemplary tales about monks and wandering holy men (hijiri) who have renounced worldly life and its temptations. Through these tales Chomei probes the conditions conducive to the awakening of the bodhi-mind (hosshin), which then ensures rebirth in the pure land.

In the preface to Hosshinshû, Chömei argues that while Buddha's teachings as propagated through the various sutras are undoubtedly without compare, they are of little use to someone like himself, whose mind has not attained to this ideal. It is for this reason, he claims, that he does not aspire to the study of the profound doctrinal teachings and instead simply collects and records fleeting events that he has seen or heard of.

He maintains that his stories are intended not for others but for himself, and that he does not care whether or not others believe his tales. As he says in the preface, "Through these trivial tales that I have picked up by the wayside, I wish merely to experience, at least a little, the religious awakening of my mind [hosshin]" (HS, 45).

Chōmei's claim that his stories are meant for private use allows him to choose his material more freely and to include tales 
that he finds particularly appealing, especially those that relate to the practice of music and poetry and to the sukimono devoted to these pursuits. The presence of these tales in a work of this nature is significant and would in itself justify an investigation of the meanings that Chomei attached to the term sukimono. But an analysis of the use of the concept of suki in Hosshinshu is crucial also because it is in this new context that we encounter a more explicit articulation of the ways in which deep attachment to artistic pursuits can be integrated with a commitment to the way of the Buddha.

The purpose of this chapter, then, is a dual one. First, an examination of the term suki in Hosshinshu will highlight the extent to which attributes that constituted suki in works of the Heian period as well as in Chōmei's earlier work, Mumyōshō, reappear in Chomei's religious work. Second, identifying the points at which the meaning of suki departs radically from its earlier signification will shed some light on how the term is deployed in new ways to bring together the dominant aesthetic and spiritual ideals of the period.

In Hosshinshū, people who cultivate suki, the sukimono, are placed distinctly outside the courtly society in which they were earlier situated. They are presented as recluses who live on the periphery of society. Often, they are hijiri. Even when sukimono do happen to be members of the court, they act in a manner that goes against the norms of the society they inhabit. The sukimono's spiritual guide is nature itself. The blossoming and scattering of the cherry blossoms or the waxing and waning of the moon make them keenly aware of the principle that all things are ephemeral (shogyō mujō). This, Chömei suggests, leads them in the most natural manner to live a life completely in tune with the Buddhist teachings. Having intuited the principle of evanescence, the sukimono no longer care about wealth and fame. This detachment from worldly concerns prepares them spiritually for enlightenment (HS, 278).

Chōmei's description of the sukimono in Hosshinshū has striking resonances with the sukimono Yorimasa, whom Chōmei eulogizes in Mumyōshō $(M Y, 72)$. Yorimasa's mind is deeply sensitive to even the most apparently trivial natural phenomenon, be it the scattering of the cherry blossoms, the cry of a bird, or the rustling of the leaves in the wind. His major concern is to render what he sees and feels into poetry. His total absorption in this activity enables him to compose verses of exceptional quality, and this is what makes him a sukimono. 
In Hosshinshu, as we shall see presently, it is precisely this otherworldly absorption in poetry and music that is singled out for praise. However, there is a shift in what is seen as the final outcome of such devotion to the arts. In the case of Yorimasa, this single-minded dedication enables him to compose outstanding poetry. For the sukimono of Hosshinshu, however, this total immersion in poetry or music enables them to lead lives in complete harmony with the way of the Buddha. In order to establish this connection between the arts and Buddhist goals, Chomei rejects everything that had earlier linked the sukimono with the material world. We are presented now with a sukimono who "finds no pleasure in mingling in society and does not lament even if he falls into straitened circumstances" and who "makes it his principle not to be tainted by worldly impurities" (HS, 278). Understanding the temporary nature of human existence leads sukimono away from any attachment to wealth and fame.

Hosshinshu does more than merely state the natural affinity between the life of the sukimono and Buddhist practice. It also draws upon a whole range of theoretical formulations from Buddhist doctrine to elaborate this claim.

In order to understand the special place that Chomei carves out for music and poetry in a work of avowedly Buddhist intent, it is useful to look again at the courtly values that were central to the concept of suki in Heian times and locate their presence in the context of Hosshinshu. It is also instructive to identify the aspects of the ideal of suki that are rejected and the ones that are retrieved and remolded to fit the religious orientation of the work. ${ }^{153}$

\section{Love and ENLIGHTENMENT}

The cultivation of amorous relationships was without a doubt at the center of the concept of suki in the Heian period. The ideal sukimono was drawn to affairs of the heart and pursued them with total commitment and sincerity. The qualities of refinement and sensitivity that accompanied amorous pursuits were of the greatest importance, and it was believed that these could be best expressed through Japanese poetry (waka). The skillful composi-

153. For a translation of the stories from Hosshinshu discussed in this chapter, see Rajyashree Pandey, "Suki and Religious Awakening: Kamo no Chōmei's Hosshinshū," Monumenta Nipponica 47.3 (autumn 1992): 299-321. 
tion and exchange of poetry was an integral part of the relationship between exemplary lovers.

This figure of the ideal poet and lover, modeled on the monogatari of Heian times, continued to flourish in the romances of the Kamakura period. However, in the newly emerging and highly popular collections of tales called setsuwa, amorous relationships came to occupy a far more ambiguous position. Undoubtedly, this had much to do with the increasing importance of Buddhist values, which condemned all human attachments as delusions that prevented people from comprehending the unreal nature of the phenomenal world and from attaining enlightenment. Carnal desires in particular were considered deeply sinful and were to be shunned. It is all the more striking, then, to find that Chomei includes a number of love stories in Hosshinshü. While these are ostensibly illustrations of the follies of deluded attachment, there are occasions when Chömei allows love a more positive role in the attainment of enlightenment.

The story about the religious awakening of Kunisuke begins much like a standard episode from a tale of love. Kunisuke fell in love with a lady-in-waiting at court. Unfortunately, just when he was deeply involved with her, his father was posted out of the capital, and Kunisuke had to leave with him for the distant provinces. "He found unbearable the thought of being away from her for even one day. The prospect then of parting and going far away was more than he could endure, but there was nothing to be done. So, reassuring her with all kinds of promises, he departed, weeping all the while" (HS, 199).

Once away from the capital, Kunisuke wrote to her whenever he could, but he received no reply. After several years, when he finally did manage to return to the capital, he found that the lady was no longer at the palace because she had fallen ill during an epidemic. Not knowing where to find her, he made his way to the west of the capital, where he knew the lady had acquaintances. As he rode he happened to see a woman who had worked for his lady in the past. At the sight of him, the woman ran into the house. He followed her and there he saw the lady he had loved sitting with her back toward him, combing her hair. "He embraced her from behind and told her passionately how much he had worried about her." However, she made no reply; all she did was weep. He assumed that this was because she resented his long absence, so he tried to comfort her in various ways. She remained inconsolable and refused to turn toward him. Finally, when he forced her 
physically to face him, "he saw that her two eyes were missing. It was as if the branches of a tree had been torn from their trunk. The sight was quite unbearable to behold" (HS, 201).

The woman in her service then explained what had happened. The lady, during her illness, had one day appeared to breathe her last, and thus the person in her service had cast her body in the fields in front of the house. There the crows had pecked out her eyes. The sorrow and pain that Kunisuke felt on hearing this tale was limitless. He asked himself what karma of his in the past could have brought such a misfortune upon him; realizing that he had only this life in which to set things right, he made his way directly to Mount Hiei to become the disciple of a Shingon master (HS, 202).

What we have here is Chomei's rendering of the notion of the essential foulness of the human body (fujokan), which became an object of meditation in the Buddhist texts. Visuddhimagga by Buddhaghosa spells out at great length the various categories of the foul-the swollen, the discolored, the festering, the fissured, the mangled, the dismembered, the bloody, the worm-eaten, and so on. ${ }^{154}$ Part of the training of a Buddhist monk involved spending time at the charnel fields, there to observe, in every minute detail, the putrefaction of the human body. As Buddhaghosa's text tells us, men who do not know the true nature of the body, and hence of the self, lust after women because they are deluded into believing that all that adorns the body temporarily is real. So too women lust after men without recognizing that in reality no aspect of the human body is fit to lust after. ${ }^{155}$

Chōmei and his contemporaries belonged to a world that had inherited the aesthetic sensibilities of the Heian court. This world eschewed any reference to the human body and shunned the expression of anything unseemly. In comparison with Visuddhimagga, Chōmei's account of a lady missing her eyes is extremely restrained. Yet within the context of Japanese courtly traditions, Chōmei appears to have subverted the traditional love plot to great effect. The sudden introduction of the grotesque, bluntly inserted into a text that flows gently like the romances of old, shocks the reader out of complacency to an immediate realization of the unreality of all things and the fleeting nature of this existence.

154. Pe Maung Tin, trans., The Path of Purity: Buddhaghosa's Visuddhimagga (London: Luzac, 1971), 205.

155. Ibid., 224. 
In the next story, the building up of a love theme in the manner of Genji and its subsequent overturning is achieved with consummate skill. A man who used to be in attendance on the emperor once became intimate with a lady of great refinement ( $y \bar{u}$ naru onna). However, after a while his visits to her became few and far between, and eventually he stopped visiting the lady altogether. She passed her time forlornly, lamenting his fickleness. One day as he happened to go by her house, he was told that the mistress wished to see him. Surprised and curious, he went in through the gates. Chōmei's story proceeds in a style common to the diaries and romances of the Heian period: the weeds had grown thick, and the garden had a rough and neglected look. The sight of this filled him with an inexplicable feeling of sadness (HS, 205). Entering the house, he saw his lady kneeling and reciting the Lotus Sutra. The echoes from Genji are heard again:

She seemed to have suffered, because she was a little thinner than before. However, the sight of her hair hanging down in profusion and the extremely pure and fragile beauty of her form made him wonder if she was the same person that he had known before, such was the incomparable beauty of her appearance. He wondered with a pang of deep regret what madness had induced him to stop loving her. . . . He then began to tell her with the deepest passion how much he regretted having neglected her. (HS, 205)

The lady does not reply but continues to recite the sutra. As the man waits for her to finish, his heart filled with incomprehension, she recites a particular phrase from the Lotus Sutra two or three times. Then, while still kneeling, she breathes her last, looking as though she has merely fallen asleep. The tale concludes with the following moral:

One hears of instances of a lady turning into a stone because of her love for a man or of becoming a malevolent spirit. Although, without a doubt, love is a deeply sinful practice, the fact that the lady in this story was able to make it the means [en] for entering the pure land, and the fact that she ended her life in the way she wanted, suggest that she was possessed of truly wondrous intent [kokoro]. If only people who have suffered because of love emulated her and prayed for rebirth in the pure land, what noble spirit they would display. (HS, 206)

This story, more than any other in Hosshinshū, has all the elements of tales of love of the Heian period. Yet, the very elements 
that make the Hosshinshü story reminiscent of Genji are suggestive of the text's ambiguous stand regarding the nature and role of amorous love. It is from this point that Chomei's story takes an entirely different turn. The lady sits there reciting the Lotus Sutra without stopping to reply. The man, who had all along appeared to be in control, now waits for her to finish, "his heart filled with anxiety and incomprehension." In the end, when the lady dies with great dignity, reciting from the Lotus Sutra, the narrator comments, "I wonder how the man must have felt at that time." The ending is as unexpected for the reader as it is for the male protagonist.

It is clear from both stories discussed above that Chomei's radical revisions stem from his concern to draw the religious moral that love is a deeply sinful practice that can bring nothing but pain and suffering. Yet even when Chōmei condemns amorous relationships as deluded and sinful, many of the values attendant on courtly love, such as grace, refinement, depth of feeling, and so on, seem so basic to Chomei's definition of the "good" that he is unable to dispense with worldly love altogether. This may in part explain why Chömei allows a lady's experience of love to become the cause of her spiritual enlightenment. It is perhaps no accident that the lady who is able to convert such a "deeply sinful practice" into a means to enlightenment is a person of great refinement, purity, and beauty. We shall see presently that Chōmei establishes this connection between beauty and grace and religious awakening explicitly in some of the stories in Hosshinshu.

It is necessary to stress that Hosshinshu does not uphold the experience of love as being good in itself. It is not fulfillment in love but rather love's failure that can on occasion be turned into a means to transcend the sinfulness of such attachment. The text goes to some lengths to explain that the retribution for such attachment carries over into future lives: "If only human beings could cut off all thoughts of love and be reborn in the pure land, all pain and anguish would appear as illusory as a dream seen at night while asleep" (HS, 206). This stands in striking contrast to Chōmei's position on attachment to poetry and music and, more generally, to the ideals of refinement $(y \bar{u})$ and depth of feeling (nasake fukaki) outside the context of amorous love.

Refinement, Sensitivity, and Spiritual Purity

Amorous love, then, which was an integral part of suki and irogonomi in the Heian period, plays little part in Chōmei's search for 
the conditions leading to religious awakening. Refinement and sensitivity, however, are ideals from an earlier age that Chōmei finds easier to weave into the overriding theme of his work, namely, the pursuit and attainment of enlightenment.

A story in Hosshinshū about Saigyō is of particular interest in this context. After becoming a priest, so the story tells us, Saigyō entrusted his little daughter to his younger brother's care. After a few years, Saigyō happened to return to the capital and go past the house where his brother had lived. Remembering his daughter, he looked in through the gates and saw her, "dressed in a shabby single robe, mixing freely with the servants' children, and playing in the dirt by the side of the fence." As a point of contrast with this degraded social condition, we are presented with her physical beauty: "Her luxurious hair hung down gracefully to her shoulders. Her form too was quite exquisite; she promised to be quite a beauty when she grew up" (HS, 263). In a society where beauty and grace were thought to go hand in hand with nobility, this description serves as a reminder of the girl's respectable origins.

The story then goes on to tell us that Saigyō's wife arranged for the girl to be adopted by the lady Reizen, who looked after her with great affection. When the girl was fifteen years old, she was sent to the family of Fujiwara no Ieaki, who held third rank, to work as a lady-in-waiting. Hearing about this, Saigyô met his daughter and advised her to become a nun. The reasons he offered are significant:

\begin{abstract}
Since the time you were born, I have prayed within my heart for only one thing-that when you came of age you would become the empress's lady-in-waiting or that we could arrange for you to serve an imperial princess. That I would hear that you had ended up in the employ of a second-ranking household such as this one, I had not imagined even in my dreams. . . . So, I think that you should join your mother and become a nun and place yourself in the service of the court of the Buddha [hotoke no miya tsukae]. That, I think, would bespeak true refinement [kokoro nikushi]. (HS, 265-66)
\end{abstract}

The girl obeys her father and joins her mother, also a nun, at Amano to devote herself to Buddhist practice. The purpose of the tale is presumably to illustrate the unquestioning filial loyalty of Saigyō's daughter, who is praised for following her father's orders without a word of protest and for her ability to give up the pleasures of the secular life without regrets and lingering attachments. 
It is the portrayal of Saigyō, however, that is of particular interest. Saigyō is presented as one who has cut himself off from all worldly ties. He shows no concern for his physical appearance and lives a life of utmost simplicity. He is described as a "rugged monk, gaunt and swarthy in appearance, wearing a black habit made of hemp and a surplice" (HS, 265). His unkempt look causes children to run away in fear, indicating his total detachment from the world and the austerity of his religious practice. In this he is like other hijiri such as Genpin (d. 818) and Byōdo (dates unknown), whom Chōmei eulogizes in Hosshinshū (HS, 46-58).

Despite the fact that Saigyo has cut himself off from the world, he is unable to give up worrying about his daughter's future. There are many stories in Hosshinshü that deal sympathetically with those who have cast aside worldly life but are nonetheless unable to forget their families and those they have served. It is worth noting, however, that it is only when this attachment arises because of a close identification with courtly ideals and aspirations that the text endorses it.

Saigyo's aspirations for his daughter take the form of an overriding anxiety about her social status: his greatest ambition is to see her in the service of the empress. In his advice to his daughter to become a nun, he makes no mention of the ultimate superiority of the Buddhist way but recommends it rather on the grounds that it is the only honorable alternative to a life spent in the service of a "second-ranking household."

There is some doubt about the authenticity of this account, and the Saigyõ of this story is therefore better understood as Chōmei's own projection. Chōmei's conception of the good and the honorable in terms of elegance and refinement is clearly rooted in the courtly culture of his time.

Another story from Hosshinshü, about the middle counselor Akimoto, helps to make this point clearer. Akimoto, we are told, was in the service of the emperor Go-Ichijo (r. 1016-36). From his youth he had little cause to be unhappy with his rank and status at court, and yet he yearned only to follow the Buddhist path and to attain enlightenment. His commitment to the way of the Buddha was particularly impressive precisely because it was not born out of unhappy circumstances. Akimoto is described as a formidable sukibito (person devoted to the arts). He spent his time playing the biwa night and day, while intoning the following prayer: "Although I have committed no crime, I wish I could take the burden of it on my shoulders. Banished far away, I long to gaze at the moon from a place of exile" (HS, 221). 
At the death of the emperor, Akimoto's grief far surpassed that of the other courtiers, who gradually became involved in attending the new emperor. With time the old emperor's residence came to be neglected. When Akimoto heard of this, he was struck all the more by the transience of all worldly things. He refused to appear before the new emperor and said, "A faithful retainer does not serve two masters." Waiting until the mourning period for the emperor had ended, Akimoto then left his home and went up to Yokawa, where he took the tonsure and began to live the life of a recluse.

At this time the mother of the former emperor, Lady Jōtomon-in, inquired after him. He replied to her with the following poem:

Yo o sutete

Yado o idenishi

Mi naredomo

Nao koishiki wa

Mukashi narikeri
Although I am one

Who has cast aside the world And left my home,

My longing for the past

Remains as ever, unchanging.

We are told that Akimoto later went to live in Ōhara and devoted himself single-mindedly to Buddhist practices. While at Ohara, Akimoto was visited by the imperial regent. They spent the whole night talking, and not a word relating to worldly affairs passed between them. The regent was so impressed by Akimoto that he made Akimoto promise to be his spiritual guide. At the moment of parting, Akimoto thanked him for his visit and added, "Toshizane [Akimoto's son] leaves much to be desired." Later on when the regent thought about what Akimoto had said, he surmised that the situation was thus:

No one would speak ill of his or her own child. Even if Toshizane is not a particularly talented person, Akimoto finds it impossible to neglect him, and so perhaps Akimoto wants me to take him under my wing. Truly, even if a man turns his back on the world, how hard it is to cast aside his love for his child. No wonder, then, that Akimoto was so overwhelmed with concern for his son. $(H S, 223)$

The regent, apparently, was so moved by Akimoto's request that he went out of his way to promote Toshizane, who eventually became the grand counselor of Mino.

There are many elements in this story that are noteworthy. Akimoto is described as a sukibito, who spends his time "playing the biwa day and night" and reciting poetry by Po Chü-i, as well 
as some of his own compositions. In keeping with the other sukibito in Hosshinshü, Akimoto combines a devotion to poetry and music with a total disregard for worldly success. Although he has no reason to be discontented with his life at court, he feels naturally inclined to the Buddhist path.

The depth of Akimoto's loyalty to the emperor Go-Ichijō and, more significantly, the sensitivity and grace with which he expresses this loyalty are striking features of this tale. The choice of the medium of waka to express his loyalty to the emperor and his nostalgia for the days gone by invest his sentiments with added dimensions of both sincerity and refinement.

The story succeeds in maintaining a balance between two polarities, detachment and attachment-Akimoto's commitment to the Buddhist way and his indifference to the material world, on the one hand, and his loyalty to the emperor and his continued concern for his son's career, on the other. The potential tension is circumvented in a manner that reveals a great deal about the cultural context of Hosshinshü: it is within the larger framework of refinement and the cultivation of artistic pursuits, that is to say, of suki, that both Akimoto's religious leanings from an early age and the depth of his feelings (nasake) for the emperor are situated. It is a striking reflection of the power of aestheticism in the lives of men such as Chōmei.

In the story about Kunisuke, mentioned earlier, we are told that Kunisuke, having taken the priestly name Tōnobō, began to learn the Shingon teachings. During the course of his training, his teacher said to him, "I have heard that before you gave up worldly life you were a talented mime, and that you entertained people with your comic performances. I would like to see you perform Senshübanzei." The text suggests that the teacher wished to test the spiritual level of his pupil. Tōnobō complied as though this was a very normal request for his teacher to have made. He took some paper that served as a wrapping for the sutras, and, putting it on his head like a cap, he proceeded to dance with great elegance.

His teacher was moved to tears and praised him with the following words, "I was convinced that you would refuse to dance, but I see that you are truly a person who has experienced religious awakening. You are worthy of the greatest esteem" (HS, 204).

What is it about Tōnobö's performance that moves his teacher so deeply and convinces him that Tōnobō has reached a high spiritual level? It is not clear why Tōnobō's teacher expected 
him to refuse to dance, but that he agreed to do so was taken as a sign that he had experienced religious awakening. That Tōnobō danced without protest may have been a sign of his unquestioning obedience. Perhaps the teacher expected Tonnobō, who had cut himself off from the secular world, to refuse to dance on the grounds that it would divert him from his spiritual goals. The fact that Tonobō performed the dance without protest might well have served as proof of the fact that Tōnobō had genuinely grasped the teachings of nonduality and had gone beyond making artificial distinctions between "secular" and "religious" acts.

What stands out in the tale, however, is the causal connection that is established between the fact that Tōnobō performed the dance with great dignity and grace (medetaku mautarikereba) and the master's declaration that Tōnobō had attained religious awakening. This connection between the religious and the aesthetic is developed more explicitly in the stories that refer specifically to sukimono. In many of these, the underlying suggestion is that there is a natural link between suki and hosshin.

\section{The Natural Affinity between Suki and Spirituality}

In the story about the chamberlain grand counselor Narimichi, we are told that as a young child Narimichi fell seriously ill with malaria. His parents called in their regular Buddhist priest to chant prayers, but the priest's efforts proved in vain. In despair, his parents contemplated calling in another priest. However, Narimichi objected, saying that it would be humiliating for the priest to be dismissed at that point, given that he had looked after Narimichi since the time he had been in his mother's womb. His parents were deeply touched by his sensitivity and followed their son's wishes. Eventually the priest's prayers were efficacious, and Narimichi was cured. The text concludes with the following remarks:

Narimichi possessed a temperament such as this from an early age. In his dealings with people, no matter whether they were his inferiors or his peers, he always showed them the deepest consideration [nasake], and he left behind a reputation of being a person of great refinement [yū nari]. In all respects he was a great sukibito, and so his heart was not tainted by worldly impurities. Furthermore, his ties with women were weak, and hence the bad karma that he carried over to his next life must surely have been light. (HS, 270) 
Ima kagami narrates several episodes in the life of Narimichi. His great skill at playing the flute and composing poetry, his mastery of football, go, and horse riding, and the dedication with which he cultivates these talents are described at length. There are anecdotes too about his romantic escapades with both men and women. ${ }^{156}$

Particular stories appear in slightly different recensions, or even in identical form, in different setsuwa collections compiled at different times. It is instructive to see how a certain body of material was used for different purposes. The story of Narimichi is a case in point. Nowhere in Ima kagami is Narimichi described as a sukimono. Although he is presented as devoted to artistic pursuits and having a high level of competence in various fields, he appears to lack the sensitivity and seriousness that Chōmei attributes to him. He emerges as no more than a colorful character, and the anecdotes about him seek merely to entertain and carry no moral purport.

Hosshinsh $\bar{u}$, on the other hand, focuses on one incident to illustrate the extreme consideration that he shows to the priest in his family's service. What is stressed is his inborn sensitivity, conspicuously absent in his own parents. The text then proceeds to link Narimichi's sensitivity with his refined temperament and suggests that it is the coming together of these qualities that makes Narimichi a sukimono. As a final stage in the argument, a causal connection is drawn between his being a sukimono and his attainment of spiritual purity: "In all respects he was a great sukimono, and so his heart was not tainted by worldly impurities."

Ironically, while Ima kagami refers to Narimichi's amorous interest in both men and women, in Hosshinshu he is commended for his lack of interest in women. What is particularly significant is that Narimichi follows the Buddhist path of virtue and detachment without attempting to do so consciously. The fact that he is a sukimono leads him in the most natural way to live a life of spiritual purity. By making this connection between suki and enlightenment appear natural, Chōmei conceals his own construction of it. This becomes apparent in many other stories about sukimono in Hosshinshū.

156. Unno Yasuo, ed., Ima kagami zenshaku, vol. 2 (Tokyo: Fukutake Shiten, 1983), 50, 57-58, 62-63, 65-66. 
One such story is about the monk Eishū, a relation of Yorikiyo, the intendant of the Hachiman shrine. He is described as a person belonging to an impoverished family but whose heart is, nonetheless, drawn to artistic pursuits, to which he devotes himself single-mindedly (kokoro sukerikeru). Eishū, we are told, did nothing but play the flute night and day. His neighbors found this extremely disturbing and gradually left their homes until there was nobody left in his neighborhood. However, this did not affect him in the least.

Yorikiyo heard of Eishū's straitened circumstances and sent him a message saying that he was to ask for whatever he needed without any hesitation. Eishũ met Yorikiyo and explained what he wanted above everything else:

You have a great deal of land in Tsukushi where Chinese
bamboo grows. This is bamboo from which flutes of the
highest quality are made. I wonder if you would present
me with one such flute. This is something that I have
yearned for above everything else, but, being a person of
no consequence, it has been hard for me to obtain one.
(HS, 272)

Yorikiyo found his request so unexpected and touching that he assured him that his wish would be granted without delay. He also urged Eishū to ask for some things that would be useful in his day-to-day life. However, Eishū declined, saying:

I feel extremely grateful for your kind consideration, but I lack for nothing. If, in the second or third month, I receive a single-lined summer robe of the kind I have on, it will see me through until the tenth month. As for the rest, I entrust my daily needs to fate, and I shall somehow pass the days. (HS, 273)

Yorikiyo was so moved and impressed by Eishū's words that he declared him a genuine sukimono and hastened to have the flute sent to him. He also included several things he felt would be useful to Eishū in his daily life. Eishū accepted these gifts, and, while his provisions lasted, he invited the musicians of Hachiman shrine to his home. Supplying them with wine, he spent the days playing music in their company. Once he had run out of supplies, he reverted once more to his old habit of spending his days and nights playing the flute in solitude. In the end his dedication to music bore fruit, and he had no peer in the art of flute playing. 
The story ends with a rhetorical question, "In what aspect of life could a person with such a heart possibly commit a grave sin [kayo naran kokoro wa nani ni tsukete ka wa fukaki tsumi mo haberanl?"

In a culture in which grace and refinement were the prerogative of the noble and the wealthy, Eishu is presented as an exception. "Destitute as he was, his behavior was never mean or vulgar, and so it was only natural that no one looked down on him" (HS, 271). It is Eishū's total devotion to music that enables him to transcend his poverty. "Although he came from a poor family his heart was drawn to refined pursuits lie mazushikute kokoro sukerikerul." His dedication to music enables him also to disregard totally his material needs. When Eishū asks Yorikiyo for a flute of a high quality, his desire stems not from greed but rather from his extreme devotion to his art. As Yorikiyo remarks, it is a reflection of the fact that he is a genuine sukimono. Hand in hand with his lack of concern for material objects is his singular detachment from human beings. He does not socialize in any way with those who live around him. He is an eccentric who is utterly unperturbed by the fact that the sound of his flute drives his neighbors away from their own homes.

It is Eishū's power to transcend all material and human attachments that leads to the judgment that such a person could not possibly commit a deep sin. However, it is not Eishū's detachment alone that accounts for his spiritual superiority. As in the case of Narimichi, Eishū's life as a sukimono elevates him to a state where his heart cannot be tainted by sinful behavior. In this story, Chōmei brings together a range of attributes and integrates them into the ideal of suki. Refinement, total devotion to an art, and great mastery of it were, of course, fundamental to the ideal of suki as it came to be defined from the Kamakura period onward, and to the way in which Chomei himself uses the term in Mumyōshō. To these qualities, Chōmei adds significant new elements: unworldliness, a disregard for material needs, and spiritual purity, a heart untainted by sin.

There is no indication that Eishū actively follows the Buddhist path or that he regards the pursuit of music as equivalent to Buddhist practice. Indeed, though a monk, Eishū has no religious goal in mind. He lives only for his music. Unlike the hijiri in Hosshinshū, who refuse gifts, Eishū accepts Yorikiyo's offerings. However, these are not things that he covets for himself. They allow him to invite other musicians to his home so that he may play music all day long in their company. In the end, he becomes a flute player 
without peer, the ultimate consummation of years of devotion to a michi. However, he achieves more than a mastery of his art. In a work that aims to elucidate the conditions for religious awakening, Eishū becomes an example of a sukimono who ends up following the Buddhist path even if he does so unwittingly.

Another episode, one that follows the story about Eishu the flute player, is a variation on the same theme. Tokimitsu was an official who supervised the market place. He was also a player of the reed organ (shō). He and Shigemitsu, a teacher of the Japanese pipe (hichiriki), were once absorbed in singing a composition of gagaku music when there was an urgent message asking Tokimitsu to appear before the emperor. Tokimitsu, however, took no notice of the messenger and continued with his singing. The messenger returned to the emperor, wondering what kind of punishment Tokimitsu would receive for such behavior. Contrary to the messenger's expectations, however, the emperor was moved to tears and remarked: "Tokimitsu is truly a man worthy of the greatest esteem. How splendid it is that he can be so absorbed in music as to forget everything else. How I regret my position as emperor. If only I could walk over and listen to them perform" (HS, 274). The text concludes: "If we think about incidents such as these, we realize that suki can be specially depended upon as a means to discard all thoughts pertaining to worldly matters" (HS, 275).

Unlike Eishū, who maintains minimal contact with the outside world, both Tokimitsu and Shigemitsu are active members of court society. Eishū's disregard for his material needs is demonstrated concretely, but Tokimitsu's lack of concern over his own welfare takes a more symbolic form: he ignores the imperial summons. What Tokimitsu does in effect is undermine the authority of the emperor without any anxiety about the consequences. Flouting an imperial command could certainly lead to loss of his official post. It could also mean banishment from the capital.

Unquestioning loyalty to the emperor was, to be sure, an important ideal of courtly life. Yet it is clear from this story that the text considers total absorption in an artistic pursuit-the ideal of suki-the highest ideal. The ultimate sanction for this comes from the emperor himself, who laments the restrictions of his position. In effect, the emperor is constructed as a person who would rather be a sukimono than an emperor!

It is of great significance that every story that celebrates the theme of suki in Hosshinshû ends with a statement that points to the harmony of the way of sukimono with the way of the Bud- 
dha, or to the effectiveness of suki as a means to religious enlightenment. That Chōmei makes this link between suki and enlightenment quite consciously becomes clearer when we compare Tokimitsu's story with another rendition of the tale.

In the version in Ima kagami, we read that Tokimitsu got together one day with another old gentleman, and they began to play go and sing songs. A messenger arrived from the emperor's court, but they ignored him completely. The messenger derided them and then returned to the emperor, complaining about what had happened. However, the emperor did not order them to be punished. Instead he remarked, "How moving this is. They were so absorbed in their music that they forgot everything else. What I regret most is my position as emperor. It stops me from walking over and hearing them perform." 157

Apart from minor differences (Mochimitsu rather than Shigemitsu is named as Tokimitsu's musical partner) the plot of these two versions is practically identical. In Hosshinshu, however, the emperor does not merely remark on how Tokimitsu has forgotten everything because of his absorption in music. He also sheds tears and declares that Tokimitsu is a man worthy of the highest esteem. But what is most notable are the respective conclusions of the two versions. Ima kagami praises Tokimitsu's devotion to music but does not speak of it in terms of suki. The central thrust of the Hosshinshu version, on the other hand, is to establish a link between Tokimitsu's commitment to an artistic pursuit and the spiritual goals and ideals of Buddhism.

There are other stories in Hosshinshū that develop a similar theme. In one episode Chōmei describes the priest Rennyo as a sukihijiri. The word appears to have been Chōmei's own coinage. Through this term Chomei establishes a harmonious blend of the aesthetic values of suki and the religious ideals of a hijiri. By creating a new concept without explanations or justifications, Chōmei again presents as natural the bond between artistic and religious activities.

Rennyo one day remembered a poem that the empress Teishi had composed at the time of her death and tied to the sash of the screen curtains in the hope that the emperor would see it. The poem was:

Yomosugara

Chigirishi koto o
If you have not forgotten

The pledges we made

157. Unno, Ima kagami zenshaku, 2:444. 
Wasurezuwa

Koimu namida no

Iro zo yukashiki
Through the night,

I am drawn by the hue of the tears

You will weep in longing for me after I am gone.

When the poem came to mind, Rennyo was deeply moved. Indeed, it made such an impression on him that, weeping profusely, he recited her poem and chanted the sonsho dharani (mystic verses), offering the two as merit that would work toward her ultimate enlightenment in future lives. He kept this up throughout that long winter's night, alternately reciting her poem and the dharani, without dozing even once. The story ends with the statement, "He was indeed an extraordinary sukimono."

This story contains all the elements central to Chōmei's conception of the ideal sukimono. Like Narimichi, Rennyo was a highly sensitive person who had a natural compassion for others. The ability to be moved and to weep in an unrestrained manner was a highly exalted virtue from Heian times, and Chomei makes this quality a prerequisite for the sukimono. What moved Rennyo was the empress's expression of her love, but it was its manifestation in the form of waka that aroused in Rennyo the deepest emotions. Sensitivity, compassion, a keen appreciation of love's trials and tribulations, and their expression through poetry were all qualities that were highly prized by the aristocracy of Heian and Kamakura times. They were also qualities, as we have seen, that were central to the concepts of irogonomi and suki.

In Hosshinshū, Chōmei adds significant new elements to these qualities. For Chomei's ideal sukimono, it is important that Rennyo's compassion for the empress be expressed in Buddhist terms-hence his concern about her fate in future lives and his prayers on her behalf. But what constitutes his prayer? Not simply the recitation of a sutra or dharani. He treats poetry and dharani as if they were on a par. He recites them alternately in the conviction that they will be effective in ensuring the future salvation of the empress.

Concern for the spiritual welfare of others and according the same spiritual efficacy to waka as dharani are significant new elements Chōmei attributes to the sukimono. The single-minded devotion that leads Rennyo to recite "without dozing even once through the long winter's night" is highly reminiscent of the rigor and passion with which the great sukimono of the Kamakura period cultivated music and poetry. We have seen a very similar 
expression of Shunzei's total absorption in poetry in Sasamegoto. ${ }^{158}$ It is noteworthy, however, that Rennyo's wholehearted dedication is not to an artistic pursuit, but rather to a goal that is fundamentally religious.

Having established a vital link between Rennyo's sensitivity and his commitment to Buddhist ideals, the story proceeds. During the upheavals of the Hoggen era, we are told, the cloistered emperor Sutoku (r. 1123-41) was forced to move to Sanuki and live there under pitiable conditions as a virtual prisoner: "The sukihijiri Rennyo, about whom I spoke earlier, heard that it was difficult for anyone to go and visit the emperor in his place of exile. Being a person who felt the deepest sympathy for others, Rennyo was extremely saddened by the situation" (HS, 278). Rennyo undertook an arduous journey to Sanuki to pay the emperor a visit. Rennyo's own contact with the emperor had been negligible, and, hence, as the narrator informs us, the depth of his feelings for him was particularly surprising. When Rennyo arrived at the emperor's humble abode, he found it so well guarded that it was impossible for him to get in. "The day passed in vain, and in the light of the moon Rennyo wandered around outside the precincts, playing on his flute" (HS, 279). Around dawn a man emerged and led him in. The utter desolation of the place overwhelmed Rennyo, and he composed a poem and sent it to the emperor. The latter responded immediately with another poem. Reading it by the light of the moon, Rennyo was deeply struck with awe and reverence and returned to the capital, weeping all the while.

Here the qualities that make Rennyo an ideal sukimono are divorced from all Buddhist associations. What stands out is Rennyo's depth of feeling for the plight of the emperor. It is his deep sensitivity (nasake fukaki) and his consideration for others that motivate Rennyo to undertake a long and difficult journey to visit an emperor with whom he has not had any personal contact.

Equally important is the fact that Rennyo's sensitivity finds expression in forms that are culturally sanctioned. It is above all through poetry and music that he voices his sympathy for the exiled emperor. We are not told how it happens, but presumably the beauty of his flute playing is instrumental in his being allowed to enter through the gates.

Although an actual meeting between Rennyo and the emperor does not materialize, it is poetry that enables them to com-

158. See chapter three, p. 104. 
municate their feelings to one another. Both the depth of his feelings for others and the sensitive expression of his feelings through music and poetry are signs of the sukimono in Rennyo. The anecdote about Rennyo and the emperor carries no religious significance. It is as if Chōmei, having established Rennyo's credentials in the earlier episode, now feels free to recount a tale that highlights the ambiance-the desolate landscape, the moon, the flute playing-that is so much a part of the world of suki.

\section{Music and Poetry as Religious Practices}

In the stories about Narimichi, Tokimitsu, and Eishū, Chōmei constructs a natural affinity between the way of the sukimono and the Buddhist path. In other tales in Hosshinshu, he demonstrates how priests and laymen alike take up poetry and music consciously as religious practices.

The story of the priest Honichi is a case in point. When asked what kind of religious observances he followed, Hōnichi would coyly reply that he performed the three religious practices of the morning, noon, and night (sanji no gyö). When pressed further to describe these practices, he admitted that he recited three poems at dawn, noon, and dusk without missing a day and in this way meditated on the transience of life. The text continues:

This was an extremely unusual practice, but just as the ways in which people's minds advance vary greatly, so too religious practices cannot but be diverse. In the commandery of Jun in China, the holy man Tanyung made crossing over a bridge a religious practice [gyō] that would lead him across to the pure land. The priest Ming Keng from the commandery of Ho reached the pure land by punting his boat across the waters. (HS, 276)

Almost every kind of activity, it would appear, can be seen as constituting religious practice, provided that it is performed with sincerity. There is a story in Hosshinshü about an old man whose religious observance ( $g y \bar{o})$ was of a quite novel nature. This old man used to wander about begging and saying mashite (all the more so) no matter what he saw or heard (HS, 127). A holy man in Yamato Province once dreamed that this old man was going to attain rebirth in the pure land. Seeking him out, the holy man asked him repeatedly to describe his religious practice. When pressed, the old man replied that he did indeed follow one religious practice, that of mashite. Whenever things were painful to 
bear, he would merely say to himself mashite-how much more awful would be the sufferings of hell-and this would make him fear the evil path. Similarly, when he saw beautiful things, he would say mashite-how much more spectacular would be the beauties of the pure land-and thus prevent himself from being tempted by the delights of worldly life. The holy man was so impressed that he folded his palms and paid obeisance to the old man. The text then reads: "Even if this old man most certainly did not meditate on the magnificence of the pure land, he always kept in mind the fundamental principles of the doctrine, no matter what the situation, and this too was a kind of religious practice [gyō] leading to the pure land" (HS, 128-29). In this way, Hosshinshu establishes the principle that even the most trivial acts can become gyo if performed in the proper spirit. However, the cherished tradition of poetry is singled out and awarded special status. In the story about the priest Honnichi, who made waka his religious practice, poetry is accorded a privileged place as a gyō: "The way of poetry can penetrate to the essence of things: how much more so, then, can we depend on it and through this means calm the mind and meditate on the transience of all worldly things!" (HS, 276).

Music, too, is accorded an important place as a religious practice. The story of the hijiri Kakuno, who lived by the grave of Shōtoku Taishi, is a case in point (HS, 311-12). Kakunō's love of music, we are told, was extraordinary. He would spend his days and nights fashioning biwa and kotos out of planks and playing on them with bird feathers. He also made flutes from bamboo. As he played on these various instruments, he would remark to himself, "How wonderful must be the sound of the music of the bodhisattvas and their entourage." This thought would move him so deeply that he would sit and weep. In the end, the hijiri died just as he had wished, with the sound of music playing in his ears. His death was followed by all the signs of his having achieved rebirth in the pure land. Even after several days, his body did not decompose. People then gathered round and revered him as a Buddha. On the forty-ninth day his body disappeared and was not seen again. The text concludes, "Thus music, too, for those who believe in it as a religious practice $[g y \bar{o}]$, will become a religious observance [gyō] that will lead to the pure land."

Kakunō, like many of the hijiri in Hosshinshü, is an eccentric man who does not care for worldly matters and, like Eishū, spends his time playing music with an obsessive passion. Implicit here is that his dedication to music is responsible for his attain- 
ment of rebirth in the pure land. There are indications within the story, however, that Kakunō does not separate his musical activities from his thoughts about the pure land. Unlike Eishū, Kakunō, even while playing music, always thinks of the more beautiful music of the bodhisattvas as they welcome into the pure land those who have attained enlightenment. There is, however, no explicit indication that Kakunō is working toward his own spiritual awakening. A more self-conscious assertion of music as religious practice can be seen in another episode in Hosshinshu, one that follows the story about the priest Hönichi.

Daini no Sukemichi, an extremely talented biwa player, would have nothing to do with customary religious observances. Every day he would go into the Buddhist prayer hall and play melodies on his biwa. He would have someone count his recitals and have them transferred to his accumulated merit for the attainment of rebirth in the pure land (gokuraku ni ekō shikeru; HS, 277-78).

The conventional practice was to recite the nenbutsu and, on the basis of the number of recitations, accumulate merit toward the attainment of enlightenment. As in the case of Hōnichi, the narrator finds it necessary to forestall any criticism of Sukemichi's unusual practice with the following assertion: "Religious devotions are dependent on actual performance as well as on the sincerity of one's intentions, and thus there is no way in which such practices can be condemned as worthless." At this point there appears an elaborate statement in defense of suki and its special role in reaching the state of mind conducive to enlightenment:

The practice of suki is one in which a person finds no pleasure in mingling in society. He does not lament even if he falls into straitened circumstances. He is moved by the blooming and scattering of the cherry blossoms. He calms the mind by meditating on the waxing and waning of the moon. He resolves not to be tainted by worldly impurities. As a result, the fundamental truth of the transient nature of life reveals itself spontaneously to him, and any attachment he may have had to fame and wealth also comes to an end. This is the first step toward escaping from the cycle of births and deaths and entering nirvana. (HS, 278)

Devotion to poetry and music are of course fundamental to Chōmei's understanding of suki. It is precisely in order to justify Hōnichi's recitation of poetry and Sukemichi's performance of 
music as highly worthy religious practices that Chōmei spells out what he considers the unique place of suki in the attainment of enlightenment. It is striking that extreme attachment to the artsas in the case of Eishū, Kakunō, Sukemichi, and Tokimitsu-is not viewed in those terms but is seen rather as a measure of otherworldliness. Attachment in such instances is turned on its head and redefined as total detachment.

This is in sharp contrast with the text's presentation of other kinds of attachment ( $s h \bar{u})$. There is a story, for instance, of a scholar of Chinese, Sukekuni, who loved flowers above all else. So deep was his attachment that he even composed a Chinese verse saying that he would continue to love flowers in his future lives as well. As it happened, he received rebirth as a butterfly as retribution for his obsession with flowers (HS, 70-72). So too, a priest who was a serious follower of the Buddhist doctrine was nonetheless deeply in love with a mandarin orange tree, and as a result of even this trivial attachment he was reborn a snake and lived at the foot of the orange tree. The moral purport of these anecdotes is spelled out clearly: "There can be no doubt whatsoever that for every moment of deluded attachment we receive rebirth in a lowly animal form. Truly this should arouse in us the greatest fear" (HS, 72).

By the same token, the priest who finds himself too attached to a pot and decides to destroy his love by destroying the pot is singled out for praise (HS, 69). So too, another priest who is overly attached to the plum blossoms on his tree one day suddenly realizes the gravity of his deluded attachment (mōshü) and cuts the tree down (HS, 69-70).

The passionate artistic pursuit of the sukimono, however, is always accompanied by lack of concern for all other worldly matters, and this forms the basis of Chomei's argument that the sukimono naturally attains a state of mind that can experience religious awakening (hosshin).

In one story in Hosshinshū, the famous Tendai priest Genshin (942-1017) believed that waka constituted the sin of kigo (fancy phrases) and thus refused to compose any poetry. Kigo, as mentioned earlier, was regarded as one of the "sins of word" in Buddhism. One day around dawn, when Genshin stood gazing over Lake Biwa, the sight of the boats going back and forth, shrouded in mist, brought to his mind the poem, "To what shall I compare the daybreak. . . ." At that moment, he was deeply moved and declared that the sacred teachings and Japanese poetry were in 
fact identical (shōgyō to waka to wa hayaku hitotsu narikeri). From that time onward he would compose and recite poems whenever an appropriate occasion arose (HS, 276-77).

Thus, even for one as unreceptive as Genshin, poetry more than any other medium enables him to capture the essence of what he sees and experiences. The sight of the boats plying back and forth on Lake Biwa spontaneously leads him to recall the poem by the priest Manzei (ca. 720), comparing human life to the boats traveling in the morning mist. More poignantly than any scriptural writing, waka has the power to make Genshin intuit the transient nature of worldly existence. He once dismissed waka as kigo; now he is forced to take a diametrically opposite view of the matter.

An interesting example of a slightly different conception can be seen in an alternative version of the story that appears in Mujū Ichien's Shasekishū. Mujū relates how Genshin had a pupil who liked to compose poetry. Genshin disapproved of this and felt that the pupil was taking himself away from his real task, namely, the pursuit of serious religious studies, and that he would corrupt the other students. He decided to have the boy sent home. The latter, quite unaware of these plans, stood on the verandah watching the moon. Cupping his hands as if he were going to scoop up some water, he recited the following poem:

Te ni musubu

Mizu ni yadoreru

Tsuki kage wa

Aru ka naki ka no

Yo ni mo sumu ka na
We live in a world

Not knowing whether or not it is real Like the reflection of the limpid moon That dwells in the water, Which I hold in my hands.

Genshin, Mujū tells us, was so deeply moved when he heard this that he took to composing waka himself. ${ }^{159}$ In Shasekishu there is no mention of Genshin equating the sacred teachings with poetry. Also Muju makes clear that, in his view, only poetry that serves the Buddhist cause can be justified. ${ }^{160}$

In the stories in Hosshinshu that deal with the arts, Chōmei equates total devotion to poetry and music with the ideal of suki. This is a view that is also reflected in Mumyōshō. However, in Hosshinsh $\bar{u}$ there is clearly a shift in emphasis. In this text, he seeks

159. Watanabe Tsunaya, Shasekishū, 219-20.

160. Ibid., 220-21. 
to establish that the pursuit of the ideal of suki leads to an intuitive understanding of the principle of transience, and this in turn helps rid the mind of all attachment to wealth, fame, and other temptations that tie human beings to the temporal world. Once such a state of mind is reached, Chōmei claims, the ultimate goalrelease from the cycle of births and deaths and the attainment of nirvana-comes closer to hand. It is within the framework of suki that he explains the spiritual purity of men like Eishū, Tokimitsu, and Rennyo.

Nonetheless, it is important to note that the moralizing statements at the end of each anecdote fall short of making the assertion that suki and the dharma are one. There is a significant structural disjuncture within the stories. The anecdotes themselves unambiguously celebrate the lives and deeds of various sukimono, but the statements at the end of the stories have a rather different tone. More defensive, they appear to argue with imaginary adversaries about the validity of artistic practices as religious observances. Thus, even when the anecdote itself establishes as selfevident the claim that waka constitutes religious practice, as in the story about Honichi, the didactic statement attempts to strengthen the claim by theorizing that waka can be depended upon (tayori) as a means to calm the mind and meditate on the evanescence of worldly life (HS, 276). So, too, in the story about Tokimitsu's devotion to music, the conclusion argues that suki can be especially depended upon (tayori) as a way to discard all thoughts of the material world (HS, 275). The didactic statements take recourse to the Buddhist notion of expedient means and argue that art can be seen as a means, a support for reaching the ultimate. With this idea of mediation, a hierarchy is inevitably established in which the religious goal takes supreme position, while the arts can be justified only as a means to achieve this goal.

A sense of ambivalence remains an important feature of these stories. In almost all the stories that deal with the arts, we sense Chōmei's struggle as a serious litterateur and dedicated Buddhist, seeking to bring together the reigning aesthetic and religious ideals of his society. On occasion, as in the stories about Rennyo and other sukimono or in the statements where the practice of music and poetry is equated with the recitation of the nenbuts $u$, the conflict seems settled. At other times, rather different statements emerge, seeking to defend these same "deluded" practices as means to a religious end. 
On one occasion Hosshinshū even questions the legitimacy of the very pursuits that have been eulogized in other instances. We are told of a learned scholar of Chinese who fell seriously ill. When he had not long to live, a virtuous man who was to be his spiritual guide visited him and urged him to recite the nenbutsu. However, the scholar's mind was so steeped in images of the wind and the moon (i.e., poetry), to which he had been excessively attached (yoshu) over the years, that he appeared to be unable to concentrate his thoughts on the pure land. The priest, who (we are told) was probably a man of great discernment, stopped recommending the nenbutsu and for a while talked to the scholar about poetry and other subjects that interested him. When it looked as though the scholar was satisfied and felt greater confidence in the guide, the latter said:

For years now you have composed unexcelled verse. Undoubtedly you will leave behind Chinese poetry of the highest acclaim. What a pity that you have not composed a single verse $[f u]$ on the pure land. It is true that there are many beautiful sights in this world that are hard to cast away. Imagine how many more poetic conceptions the beauties of the pure land will inspire within you.

As the beauty of nature was deeply imprinted in the scholar's mind, he envisioned before him the pure land, and the magnificence of this served as a means by which he was spiritually awakened. This led him to recite the nenbutsu, and he died as he would have desired, with the knowledge that he would be reborn in the pure land. The tale concludes, "Some people say that this was a story about the monk Yasutane, but as he was a strict adherent of the religious path, I do not believe that at the moment of his death he would have let other thoughts interfere with his contemplation of the pure land" (HS, 313-14).

In this story, poetry is not depicted as being in natural harmony with the Buddhist path. Indeed, it places art in direct opposition to the religious ideal. Through the maneuvers of the spiritual guide, however, poetry serves in the end as an expedient means that leads the scholar to visualize the magnificence of the pure land and thereby arouses in him the desire to attain rebirth there. But there is nothing automatic about this. It testifies only to the skill (the "discernment") of the priest. Poetry is efficacious in this instance. It is like any other expedient means, no better 
and no worse. The statement about the monk Yoshishige Yasutane, whom Chomei admired greatly, is a categorical assertion of the superiority of prescribed religious practices.

It is important to stress, nonetheless, that this is the only episode within Hosshinshu that presents a negative view of poetry (where it is seen as a hindrance to the attainment of the pure land). It is perhaps no coincidence that poetry in this episode refers to the Chinese $f u$, which was associated with artifice and embellishment, in contrast with waka, which claimed to be a natural expression of human emotion. Waka occupied an unchallenged, hallowed space in Chomei's works and was integrally tied to the ideal of suki. Indeed, as we have seen, the narratives in Hosshinshü strongly suggest that religious awakening is the natural corollary to the cultivation of suki.

The presence in Hosshinshu of stories that deal with the role of art in the quest for enlightenment is indicative of the importance that Chomei attaches to the arts in his vision of the ideal Buddhist life. In a work in which Chomei's avowed intent is to elucidate the conditions conducive to enlightenment, Chōmei smuggles in aesthetic categories that enable him to make a place for poetry and music. In some stories, the text presumes a natural affinity between religious awakening and the pursuit of music and poetry. At other times, these artistic practices are viewed as an expedient means that leads to religious awakening.

Hosshinshū draws upon a variety of discourses within Buddhist doctrine to justify this role for the arts. The term suki is central to Chomei's interpretation of the religious ideal itself. The sukimono in the tales in Hosshinsh $\bar{u}$ are totally devoted to their art, and it is precisely through this devotion that they are able to achieve spiritual purity. Thus, suki in some stories in Hosshinshü becomes an essential condition of hosshin. 


\section{Chapter Five}

\section{The Sukimono as Recluse: Hōjōki}

Hōjōki is Chōmei's best-known work, and it has been the subject of considerable debate. Scholars have traditionally regarded it as an authentic account of Chōmei's life after he took the tonsure. From Hojokiki, scholars have also reconstructed some of the earlier events in his life. For example, Hōjōki tells us that its author inherited the house of his father's grandmother and lived there for a long time, that he lost his position and fell on hard times, and that he finally took the tonsure and spent several years in Ōhara before retreating to his ten-foot-square hut on Mount Toyama in Hino.

The evidence from the diary of Minamoto no Ienaga, Chōmei's contemporary, lends credence to some of these statements, and Hojjoki can indeed be read as a work that draws upon actual events. However, it cannot simply be read as a factual account of Chömei's life, for to do so would be to ignore the fact that Hōjöki is, first and foremost, a literary text, a cultural construct that draws upon well-established literary tropes and themes that appear in earlier writings in Chinese and Japanese. Hōjoki is, then, both literary and autobiographical, echoing the works of Po Chü$i$ and Yoshishige Yasutane, as well as the canonical Vimalakirti Sutra. Hojōki is not autonomous and self-contained but an intertextual construct. As Julia Kristeva notes, "Every text takes shape as a mosaic of citations, every text is the absorption and transformation of other texts." 161

161. Julia Kristeva, Desire in Language: A Semiotic Approach to Literature and Art, trans. Thomas Gora, Alice Jardine, and Leon S. Roudiez (Oxford: Basil Blackwell, 1980), 66. 
The central question in Hōjōki concerns the nature and role of artistic practices vis-à-vis Buddhist goals and ideals. As argued earlier, this question was a well-established literary trope in medieval writing, and it provides for Chomei the context and the language with which to formulate and come to terms with the potentially contradictory pulls of engagement and detachment. At the same time, Hojjoki goes beyond a conventionalized and rhetorical resolution of this dilemma. Instead, the dilemma becomes central to Chömei's narrative and gives the work much of its dramatic tension.

Hōjōki begins with a long exposition on the natural and man-made disasters that had ravaged the capital over the years. The opening section is intended to serve as unquestionable proof of the basic impermanence of worldly life. It also demonstrates the wisdom of rejecting the material world in favor of a life spent as a religious recluse. The text then proceeds to describe a way of life that is free of all social constraints and material attachments. This life makes it possible to move easily from religious practices to the composition and recitation of poetry and musical performance. Toward the end of the work, there is a dialogue between the enlightened mind and the deluded mind, with the former accusing the latter of still being steeped in worldly attachments, while going through the motions of a holy life. The work ends on a note of ambiguity and tension that stands in contrast to its earlier relaxed and self-assured mood.

In Hōjoki there is a contradiction between two different realms, namely, the religious and the mundane. The religious is symbolized by the life of the recluse aspiring to a state of mind conducive to enlightenment. The mundane encapsulates his abiding interest in poetry and music, his appreciation of the beauty of his natural surroundings, and his love of his hut. By situating the tension between these two realms within the context of his own life, Chōmei develops and pursues another extremely interesting perspective in his continued search for an ideal life, one that incorporates both the ways of music and poetry and the way of the Buddha.

Only by reading Hōjöki in an intertextual framework can we fully appreciate its richness. I shall begin by looking at the Vimalakirti Sutra, some of the writings of Po Chü-i, Chiteiki (Record of the Pond Pavilion) by Yoshishige Yasutane, and the literary construct hōjo itself in order to see how Chōmei draws upon Chinese and Japanese literary and religious traditions in the construction 
of his own work. These texts are unmentioned but easily recognizable points of reference in Hōjöki, and they provide a context for highlighting the dilemma of reconciling worldly pursuits and attachments with a commitment to Buddhist ideals and practices.

\section{THE VIMALAK̄IRTI SUTRA}

Chōmei begins Hōjōki with the well-known and oft-quoted passage, "The flow of the river is ceaseless and its water never the same. The bubbles that float in the pools, now vanishing, now forming, are not of long duration: so too in the world are man and his dwellings." 162 This echoes the Vimalakirti Sutra: "This body is like a mass of foam that is intangible. It is like a bubble that does not last long. . . . It is like a dream . . . a shadow . . . an echo ... a floating cloud ... lightning." ${ }^{163}$ Chōmei's choice of this sutra was not fortuitous. In building a ten-foot-square hut (hōjo) and attempting to lead a life of spiritual purity, Chömei consciously uses the figure of the bodhisattva Vimalakirti as his model. Toward the end of Hōjöki, Chömei refers directly to Vimalakỉrti and reproaches himself for having followed him in form alone: while living in a hut that resembles that of Vimalakirti, he has, as he puts it, continued to be even more deluded than the most foolish of Buddha's disciples.

However, Chōmei does more than merely echo occasional phrases from the Vimalakirti Sutra. Both the structure and meaning of Hojoki consciously derive from this highly popular Buddhist text, which is an account of the teachings of the layman Vimalakirti, who lived in the city of Vaisali in India during the time of the Sākyamuni Buddha. Although he was a wealthy householder, Vimalakirti's spiritual state was that of a bodhisattva. It was to save human beings that he stayed on in Vaisali and continued to live the life of a householder. Although a layman, Vimalakirti was free from all worldly attachments. Although he was rich and was married, with children, he lived a pure life; he could partake of worldly pleasures with total detachment. The sutra explains that Vimalakirti, with his profound understanding of the Mahäyāna teachings, used a variety of expedient means for the benefit of sentient beings. It is for this reason that he was able to enter a house of

162. HK, 15. Keene, "An Account of My Hut," 189.

163. Luk, Vimalakirti Nirdesa Sutra, 17-18. 
prostitution and there preach the dharma by revealing the sin of sexual intercourse.

The sutra tells us that as one of his expedient means Vimalakirti pretended to be ill. This attracted thousands of people, including kings, ministers, and officials, to his bedside. Using his illness as a metaphor for the impermanence of the body and of worldly possessions, he taught them about pain and suffering. When Sakyamuni heard of his illness, he asked his disciples to pay Vimalakirti a visit and inquire after his health. However, none of his disciples felt up to the task of engaging in a philosophical debate with Vimalakirti, and all of them, under one pretext or another, excused themselves. Finally the Buddha turned to Mañjuśrí, "the one of superior wisdom," and the latter agreed to visit Vimalakirti, accompanied by bodhisattvas, sravaka, and deva.

Vimalakirti knew in advance of their arrival, and, using his transcendental powers, he emptied his house of all attendants and all furniture except his sickbed. What ensues is a dialogue between Mañjuśri and Vimalakirti, and the sutra reaches its climax in the chapter on nonduality. After those who have accompanied Mañjuśrī offer their definitions of nonduality, Mañjuśri proffers his own opinion, "When all things are no longer within the province of either word or speech, and of either indication or knowledge, and are beyond questions and answers, this is initiation into the nondual dharma (funi hōmon)." 164 Then Mañjuśrî asks Vimalakirti to tell everyone present his own view of nonduality. Vimalakîrti keeps completely silent, and Mañjuśrỉ then exclaims, "Excellent, excellent; can there be true initiation into the nondual dharma until words and speech are no longer written or spoken?"165 This is what came to be known as the famed silence of Vimalakirti.

Imanari Genshō has convincingly demonstrated the deep structural affinities between Hojojoki and the Vimalakirti Sutra. ${ }^{166}$ For instance, in developing the theme of evanescence (mujō) in the first half of Hōjoki, Chōmei turns directly to the sutra, which says, "[This body] is ownerless for it is like the earth. It is egoless for it is like fire. It is transient like the wind. It is not human for it is like water. It is unreal and depends on the four elements for its existence. It is empty, being neither ego nor its object." 167

164. Ibid., 100. See also LaFleur, Karma of Words, 109.

165. Luk, Vimalakirti Nirdesa Sutra, 100.

166. Imanari Genshō, "Ren'in Hōjōki no ron," Bungaku 42.2 (1974): 115-

27. See also LaFleur, Karma of Words, 107-15.

167. Luk, Vimalakirti Nirdesa Sutra, 18. 
Imanari finds the reference in Hōjōki to the four elements (shidai) significant, and he suggests that Chomei has this passage in mind when he speaks of human suffering. Through a long account of actual disasters that happened in Chōmei's own lifetime, afflictions directly caused by these four elements, he illustrates the theme of mujo. In the last and much discussed passage of the work, Chömei questions his own claims to spiritual purity and castigates himself for continuing to be deeply steeped in worldly attachment. Even here, argues Imanari, Chōmei follows the Vimalakirti Sutra.

Imanari claims that Chōmei is very much aware that his decision to lead the life of a recluse has divided the world falsely into two parts-the secular and the religious. This is a deliberate play on the life of Vimalakirti, who, although a layman, is able to counter the discriminating dualizing questions that are posed by the intellect with a profound silence: proof of his understanding of the doctrine of nonduality. For Imanari then, it is in order to illuminate the doctrine of nonduality that Chōmei constructs a work in which he first sees himself and his life in terms of dichotomies and then resolves them by abandoning words in the manner of Vimalakirti. Chomei's elaborate description of the pleasures of the solitary life in the midst of nature is, for Imanari, a clever device, Chomei's own expedient means to illustrate the profundity of the doctrine of nonduality. We shall have more to say about Imanari's reading of $H \overline{o j} \bar{o} k i$ later in the chapter. At this point the importance of his argument lies in demonstrating that Chömei does not merely allude at random to the Vimalakirti Sutra; this religious text is central to the very structure and theme of Hōjokit.

\section{Hōjō: The Idealized Dwelling}

In Höjōki, Chōmei says that his choice of a ten-foot-square hut is inspired by the dwelling that Vimalakirti moved into when he pretended to be taken ill and then explicated the doctrine of nonduality. The sutra itself makes no mention of this hut, but merely points out that Vimalakirti emptied his house of all furniture and belongings. Chōmei's ten-foot-square hut stems from another source-the widespread story that when the pilgrim Wang Hsuan-t'se passed the ruins of a small cottage in India, he was told that it was in this modest dwelling that Vimalakirti had debated with Mañjuśri. Amazed, he measured the foundations and found them to be ten feet square. This was the basis for a practice 
popular in T'ang China, whereby Buddhist dignitaries and lay scholars went into seclusion and lived in fang chang (hōjō). ${ }^{168}$

However, the use of the term fang chang among Chinese Buddhists went back earlier than Wang Hsuan-ts'e by at least a century. Wang Chin (d. 505), for example, explains that a fang chang was a structure in a temple complex, set up for the purpose of sheltering texts and images. Thus, Wang Hsuan-ts'e's testimony may have simply been a written justification of a legend that was already circulating in China before his seventh-century journey. ${ }^{169}$

The term has an even longer history when we examine the Taoist legends in which fang chang already encapsulated a mixture of opposites-detachment and riches, physical and spiritual pleasures, great opulence as well as self-denial and detachment. Thus, the Chinese antecedents of the term hojōincorporated a range of meanings drawn from a range of religious traditions. However, many Chinese writers employed the term specifically to signify rustic simplicity and spiritual purity. Poets such as Po Chü-i referred to their rustic retreats as fang chang. In one of his poems entitled "Sick Leave" for example, Po Chü-i writes: "For restful thoughts one does not need space; the room where I lie is ten feet square." 170

The term hojjo (fang chang) thus was not merely a name for a dwelling of a particular size. It came to be a symbol of rejection of the world of ostentation and of genuine commitment to the Buddhist path. The practice of recording one's personal reflections from the seclusion of the hojo gained ground in Japan during Chomei's times and is reflected in the postscripts that rounded off some of the setsuwa collections written by Chömei's contemporaries. The author of Senjusho, for instance, wrote in the epilogue that he had recorded these stories in his ten-foot-square hut (hōjo no io ni te shirushi owarinu). ${ }^{171}$ Similarly, in Kankyo no tomo (A Companion in Solitude) we are told that the author compiled the work in a ten-foot-square hut of grass on the peaks of Nishiyama

168. See Martin Collcutt, Five Mountains: The Rinzai Zen Monastic Institution in Medieval Japan (Cambridge, MA: Harvard University Press, $1981), 197$.

169. I owe much of the information on the history of the use of the term fang-chang to Robert Hegel's unpublished paper, "Emptiness and Riches in a Tiny Space-the Many Meanings of Höjo."

170. Arthur Waley, Chinese Poems (London: George Allen and Unwin, 1946), 123-24.

171. Nishio, Senjūshō, 414. 
(Nishiyama no mine no hōjō no kusa no iori ni te shirushi owarinu). ${ }^{172}$ The word was a literary construct that had become a well-established topos in Chinese and, later, Japanese writing. Chömei's use of the term, as we shall see, evoked the wealth of meanings that were encoded within it.

\section{Po ChU-I's Thatched Hall}

As the title of Chōmei's work suggests, Hōjōki was an account (ki) of his life spent in a ten-foot-square hut. The $k i$, or chi as it was known in Chinese, was a kind of chronicle or record of events that purported to be objective and authentic, and it was a well-established genre of Chinese writing. "In T"ang times it was used for descriptive prose pieces, particularly those that commemorate a journey or outing, a building, or a natural scene of unusual beauty." ${ }^{173}$ It was in emulation of the Chinese form that Japanese writers composed their own short, reflective, prose pieces.

When Po Chü-i was dismissed from his position at court in 815 and exiled to a provincial post south of the Yangtze River, he is believed to have visited Mount Lu. He fell so in love with the place that he built himself a "grass-thatched hall" (ts'ao-t'ang) there early in 817. His account of his life in this hut is entitled Lu shan ts'ao-t'ang chi (Record of the Thatched Hall on Mount Lu). ${ }^{174}$ In writing his work in the chi form, Po was following a widely practiced tradition in Chinese literature. The "grass-thatched hall" (ts'ao-t'ang) was a term used by the famous poet Tu Fu in speaking of his home in Ch'eng-tu. Po's choice of Mount Lu itself was perhaps inspired by the fact that a recluse with the surname K'uang was said to have lived there in ancient times. ${ }^{175}$

In his work Po Chü-i describes, first of all, the simplicity of his dwelling. The beams and the walls are left unpainted; the windows are covered with sheets of paper; the blinds and curtains are makeshift. His hut has, among other things, a shelf for his lacquered zither and some volumes of Confucian, Taoist, and Buddhist

172. Minobe Shigekatsu, ed., Kankyo no tomo, Chūsei no bungaku (Tokyo: Miai Shoten, 1982), 163. For a translation of book two of this work, see Rajyashree Pandey, "Women, Sexuality, and Enlightenment: Kankyo no tomo," Monumenta Nipponica 50.3 (autumn 1995): 325-56.

173. Burton Watson, Four Huts: Asian Writings on the Simple Life (Boston: Shambala, 1994), 5.

174. In Chao Ts'ung, ed., Ku-wen kuan-chih (Hong Kong: Yu-lien, 1960), 866-68.

175. Watson, Four Huts, 4-5. 
writings. ${ }^{176}$ Unlike Kamo no Chōmei, Po-Chü-i writes not as a Buddhist who has gone into seclusion, but rather as a gentleman scholar for whom an important element of the hermetic life is a study of a wide range of texts from the Chinese philosophical canon.

Po-Chü-i portrays his own life in his hut as one of utter contentment, away from the ambitions and vanities of worldly life at court. "One night here and my body is at rest, two nights and my mind is content, and after three nights I' $m$ in a state of utter calm and forgetfulness." ${ }^{177}$ In striking contrast to Hōjōki, Po Chüi's work stresses the total harmony of his body and mind in his idyllic surroundings. The only note of regret is that his job as a court official does not permit him to settle down on Mount Lu immediately. He expresses the hope that once he has fulfilled his worldly obligations-"married off my younger siblings and served out my term as marshal"-he will be able to spend the rest of his life in his favorite surroundings at Mount Lu.

Po Chü-i describes the unusually beautiful natural surroundings. Speaking of the waterfall east of the hall, for example, he says,

In twilight and at dawn it's the color of white silk, and at night it makes a sound like jade pendants or a lute or harp. ... On four sides these are the sights that meet my eyes and ears, that my shoes and walking stick take me to: in spring, the blossoms of Brocade Valley; in summer, the clouds of Stone Gate Ravine; in autumn, the moon over Tiger Creek; in winter, the snows on Incense Burner Peak. ${ }^{178}$

Unlike Yoshishige Yasutane's dwelling, which is close to the capital, Po-Chü-i's hut, like Chōmei's, is more in keeping with the idealized dwelling of the recluse.

Po Chü-i's portrayal of life in a hut has striking resonances with the descriptions of the ideal hermitage in both Yoshishige Yasutane's Chiteiki and Hōjōki. At the same time there are major differences. Po's chi lacks the sense of tension that is a striking feature of $H \bar{o} j \bar{o} k i$. For the most part it is a celebration of the beauty of Mount Lu and of the simple pleasures of his life in his thatched hut. It also lacks the strong Confucian moral overtones of Chiteki. It is not clear whether either Yoshishige Yasutane or Kamo no Chōmei knew this essay by Po Chü-i. We do know that both of them were familiar with his poetry and that he was one of the

176. Ibid., 9.

177. Ibid.

178. Ibid., 13-14. 
best-known and highly revered Chinese literary figures in Japan. The idealization of the fang chang and of the reclusive life was a familiar topos of Chinese literature, and it was through writers such as Po Chü-i that this topos became an integral part of the Japanese literary landscape.

\section{Yoshishige Yasutane's Pond Pavilion}

In writing Höjōki, Chōmei thus brings together familiar topoi from a range of writings such as the Vimalakirti Sutra and the writings of Po Chü-i. The work that he draws upon most directly, however, is Chiteiki. Yasutane, who wrote this work in Chinese in 982, was a major literary figure in Japan; his works would have been readily accessible to Chömei. Although Hōjōki does not acknowledge its debt to Chiteiki, clearly Chomei was familiar with the work. In Hosshinsh $\bar{u}$ there is a lengthy episode in which Chomei extols Yasutane as a figure whose outstanding quality was his ability to be totally committed to the Buddhist path while at the same time remaining involved in the social activities of the mundane world (appendix two, 2:3). Chōmei refers directly to Chiteiki, saying, "It is because Yasutane had such a heart that in his literary work, Chiteiki, he wrote, 'Although my body is exposed to the sun [i.e., works at court] my heart dwells in the shade [i.e., in seclusion]"' (HS, 96). It is worth looking closely at Chiteiki to identify not only the elements it shares with Hōjoki but, more importantly, the areas in which Hōjōki departs from its model.

Chiteiki describes Yasutane's life in a house he built while still in court service. This is in marked contrast with Chōmei's Hōjōki, which is an account of Chōmei's life after he had left the secular world. For Yasutane, his house comes to symbolize a private domain in which he is able to pursue his activities as a scholar and a Buddhist without conforming to the norms and restrictions that rule his social life.

Yasutane begins with a description of the uncertainty of human dwellings and the vagaries of fortune that affect those living in the capital. His choice of a small house built on some waste land is prompted mainly by two practical considerations: he cannot afford to buy anything bigger because of the price of land; he recognizes that such a house is more in keeping with his social station.

The various buildings that constitute Yasutane's dwelling are situated around a small pond built by filling up a natural hollow. To the west of the pond is located a little temple, in which he places a statue of Amida Buddha. To the east of the pond he builds a little 
mansion that he makes his study, and to the north of the pond he has a pavilion constructed, in which he houses his wife and children. It is worth quoting at some length Yasutane's description of his own activities in the various parts of his pond pavilion:

\begin{abstract}
Although by profession I hold the position of imperial secretary, my heart dwells in the midst of the mountains. I entrust my position and title to fate, for the workings of Heaven govern all things alike. I do not seek to leave the world like the phoenix that soars up high in the winds, nor do I wish to seclude myself like the leopard that hides away in the mountain mists. I would not be a sycophant, bowing and scraping before great generals and princes. Nor do I see the need to give up the use of words or abandon carnal desires and imprint my traces in some deep mountain or dark valley. When at court, my body complies temporarily with my court duties. When at home, my heart returns permanently to the Buddha. When I go out to court I don my grass-green official robe, and although my post is a minor one, I enjoy a certain measure of honor. Inside the house I wear white hempen garments, warmer than spring, purer than snow. I begin the day by washing my hands and rinsing my mouth, and then go into the western prayer hall, where I intone the name of the Amida Buddha and read the Lotus Sutra. After my meal I go into the eastern chamber to open my books and communicate with worthy men of the past. For instance, I regard as my master the emperor Han Wen $\mathrm{Ti}$, a ruler of another era, who upheld frugality and brought peace to his people. Then there is my teacher of another age, Po Lo-t'ien [Po Clü-i] of the T'ang period, who composed unexcelled verse and used it as a means to follow the Buddha's dharma; or the Seven Sages of the Chin period, friends of another age, who lived at court but whose hearts dwelled in seclusion away from the world. So I keep the company of the virtuous ruler, the great teacher, and sagacious friends. In one day I encounter the three and I enjoy three delights to last a lifetime. As for the affairs of men in the present age, they hold no attraction for me. ${ }^{179}$
\end{abstract}

The physical layout of Yasutane's house corresponds directly with the neat division that he makes between his religious and secular activities. In the western pavilion, facing as it does Amida's western paradise, quite appropriately, he performs his

179. Chiteiki, in Kakimura, Honchō monzui chūshaku, 424 25 (hereafter Chiteiki). Burton Watson, trans., "Record of the Pond Pavilion," in Japanese Literature in Chinese, vol. 1 (New York: Columbia University Press, 1975), 62-63. 
religious observances. In the eastern pavilion he engages in the study of the classics, of poetry, and of other works that define his identity as a scholar of Chinese. Even while he compartmentalizes his time and the physical space where he carries out his activities, what is striking is his portrayal of a total harmony between his commitment to Buddhist practices on the one hand and his study of classical texts on the other.

Indeed the meaningful dichotomy for Yasutane, at least in Chiteiki, is not so much between the religious and the mundane as between the public and the private realms of his life. He assigns a higher value to his private world. Although his profession demands that he work at court and take part in public activities, his innermost inclination is to retire within himself-his heart dwells in seclusion in the midst of the mountains.

The division that Yasutane makes between the body that dwells without and the heart within and the contrast between the official court robes and the pure hempen robe point to the ascendancy of the private over the public in his vision. It is his private world that allows him to engage meaningfully in Buddhist practices and to immerse himself in those Chinese classics that he finds most appealing. He admires the emperor Han Wen Ti for his sterling Confucian virtues. Po Chü-i he admires for using his commitment to poetry to serve the Buddhist cause. The seven Taoist sages exemplify for Yasutane the successful integration of public and private realms, through which the heart can remain untouched by the petty concerns of daily life.

These figures from the Chinese past enable Yasutane to retreat into his ideal world and detach himself from the preoccupations of his contemporaries, whom he sees as falling far short of the wisdom of former times. Yasutane draws on a whole range of values, emanating from both Confucian and Buddhist principles, to create the possibility of a harmonious coexistence of the outer and inner domains of his life. His strong Confucian training makes him accept unquestioningly his place within the social hierarchy and the kind of dwelling this affords him. This strong sense of the value of the here and now leads him to decry any extremist stand. He sees no reason why he should leave the world "like the phoenix that soars up high in the winds" or seclude himself "like the leopard that hides away in the mountain mists."

Yasutane's position finds its theoretical justification in Mahāyāna Buddhist practice, symbolized particularly in the life of Vimalakirti. Indeed, from the Six Dynasties period onward in 
China, Vimalakirti provided the framework for legitimizing the life of a good Confucian householder who dutifully carried out his role in society but in his private life claimed a certain detachment from worldly concerns and pursued Taoist and Buddhist practices.

Yasutane's successful synthesis of religious practices and secular duties, in the manner of Vimalakirti, allows Chōmei to draw inspiration from Chiteiki. Chōmei appears to draw a direct correlation between the religious and what Yasutane conceptualizes as the private and, correspondingly, between the mundane and the public domain. While this correspondence does underlie Yasutane's work, it is noteworthy that the study of the classics and of poetry is as much part of Yasutane's private activities as is his recitation of the nenbutsu and the Lotus Sutra.

Yasutane's retreat into his inner world finds expression in his love of his home. Having expressed his disappointment with the affairs of men, he goes on to say, "I lock my gates, I shut the doors, and alone I sing, alone I recite poetry . . . I love my home and I care for nothing outside it." 180 This, as we shall see later, has striking resonances with Chomei's own sense of pleasure at being cut off from the world, free to pursue his love of music and poetry in seclusion, heedless of the praise or censure of society. And yet there is a major divergence between the two in the way they conceptualize the relationships between themselves and their dwellings.

After expressing his love for his home, Yasutane approaches what is the opening theme of Chömei's Hōjōki-the essential transience of human habitation. He speaks of the wastefulness of lavish homes since life is far too short for anyone to live in them for long. What is most striking, however, is the way that Yasutane brings Chiteiki to a close. Nowhere does Yasutane talk of his own involvement with his dwelling in Buddhist terms; nor does he regard it as deluded attachment. What he resorts to instead is a neat Confucian solution, in which he rejects the physical structure and postulates instead an alternate architecture built on solid Confucian principles. Yasutane writes:

Ah, when the wise man builds his house, he causes no expense to the people, no trouble to the spirits. He uses benevolence and righteousness for his ridgepole and beam, ritual and law for his pillar and basestone, truth and virtue for a gate and door, mercy and love for a wall and hedge. Frugality takes the place of household goods, and

180. Chiteiki, 426; Watson, "Record of the Pond Pavilion," 63. 
the piling up of good deeds becomes the accumulation of property. When one lives in a house built of such materials, no fire can consume it, no wind can topple it, no misfortune appear to threaten it, no disaster come in its way. . . . A household such as this will prosper of its own accord, and the master will enjoy longevity. Office and rank will be with it forever, to be handed down to sons and grandsons. How can one fail, then, to exercise caution? ${ }^{181}$

In creating a conception of a home constructed out of Confucian morality, Yasutane's "real refuge is beyond corruption, safe within the realm of metaphor, buttressed on all sides by China's classical antiquity." ${ }^{182}$ This repeated invocation of Confucian principles places Yasutane's account of his house and his activities in it on a radically different plane from Chōmei's own descriptions of his life in Hōjōki.

\section{The Dwelling as a Site of Attachment}

Hōjoki draws upon Chiteiki to highlight the problem that is central to it, namely, the place of worldly activities in the life of one who has chosen a religious vocation. At the same time, it departs in significant ways from this earlier work. A large part of Hōjōki is devoted to recounting the natural and man-made disasters that ravaged the capital during Chōmei's times. As I pointed out earlier, the narration of these calamities serves to establish the essential ephemerality (mujo) of all human beings and their belongings. Chōmei writes:

Whence does he come, where does he go, man that is born and dies? We know not. For whom does he torment himself in building houses that last but a moment, for what reason are his eyes delighted by them? For what reason do his eyes take pleasure in these dwellings? This, too, we do not know. Which will be the first to go, the master or his dwelling? One might just as well ask this of the dew on the morning glory. The dew may fall and the flower remain-remain only to be withered by the morning sun. The flower may fade before the dew evaporates, but though the dew does not evaporate, it waits not for the evening. ${ }^{183}$

181. Chiteiki, 428; Watson, "Record of the Pond Pavilion," 64. 182. See Hegel, "Emptiness and Riches in a Tiny Space," 2. 183. HK, 15-16; Keene, "An Account of My Hut," 189-90. 
It is noteworthy that while Yasutane also speaks of the destruction of splendid mansions in the capital, and of the misery of the poor who live there, he fails to extrapolate the principle of mujo from his observations. For him human misery arises out of avarice, stubbornness, and cruelty. Chömei's interest, however, lies in establishing the essential transience of the world. For this reason, in his enumeration of disasters, natural calamities are at the forefront, while the major political upheavals that took place in his youth, such as the Heiji and Hoggen insurrections, find no place in Hōjōki.

There are several passages in Hōjōki that closely follow Chiteiki. However, even in these instances rather different perspectives are apparent. Yasutane writes:

One branch of a family living south of the avenue is poor, another branch north of the avenue is rich, and although the rich relatives are not necessarily virtuous, the poor relatives still must suffer shame. Then there are the humble folk who live in the shadow of some powerful family; their roof is broken, but they don't dare thatch it; their wall collapses, but they don't dare build it up again. Even when they are enjoying themselves, they dare not laugh out aloud. So, too, when they grieve they cannot raise their voices and weep.... Indeed their state is like that of sparrows in the presence of hawks and falcons.

He elaborates further the plight of the poor:

And how much worse when some great mansion is first built and then begins bit by bit to broaden its gates and doors, swallowing up the little huts all around. Then how many of the poor people have occasion to complain, like sons forced to leave the home of their ancestors, like officials of paradise exiled to the dusty world of men. ${ }^{184}$

Yasutane rounds off his assessment of the situation in the capital with the following statement: "Surely there must be some empty plot of land between the eastern and western capital. Why do people have to be so obdurate?" Clearly, Yasutane's analysis of the hardships that people face in the capital leads him to focus essentially on social problems and to express a Confucian sense of outrage at the inhumanity and obstinacy of human beings. Chōmei's reflections, as we shall see from the passage that follows, derive from a

184. Chiteiki, 419; Watson, "Record of the Pond Pavilion," 59. 
view of the world guided by Buddhist rather than Confucian principles:

All is as I have described it - the things in the world that make life difficult to endure, our own helplessness and the undependability of our dwellings. And if to these were added the griefs that come from place or particular circumstances, their sum would be unreckonable.

When a man of no great standing happens to live next door to a powerful lord, however happy he may be, he cannot celebrate too loudly; however grief-stricken, he cannot raise his voice in lamentations. He is uneasy no matter what he does; in his every action he trembles like a swallow approaching a falcon's nest. The poor man who is the neighbor of a wealthy family is always ashamed of his wretched appearance and makes his entrances and exits in bursts of flattery. And when he sees how envious his wife and children and his servants are, or hears how the rich family despises him, his mind is incessantly torn by an agitation that leaves not a moment's peace. If a man's house stands in a crowded place and a fire breaks out in the neighborhood, he cannot escape the danger. If it stands in a remote situation, he must put up with the nuisance of going back and forth to the city, and there is always a danger of robbers.

Those who are powerful are filled with greed, and those who have no protectors are despised. Possessions bring many worries; in poverty there is sorrow. He who asks another's help becomes his slave; he who nurtures others is fettered by affection. He who complies with the ways of the world may be impoverished thereby; he who does not appears deranged. Wherever one may live, whatever work one may do, is it possible even for a moment to find a haven for the body or peace for the mind? ${ }^{185}$

In speaking of the grief and hardships that material circumstances bring, Hōjōki relies heavily on Yasutane's Chiteiki, particularly when it speaks of the plight of the poor who find themselves the neighbors of the rich, even echoing the simile of sparrows in the presence of falcons.

Yet despite this borrowing, the similarities between these two passages are superficial, because the central message is based on radically divergent premises. Fundamentally, Hōjōki is not concerned with human misery as a condition arising out of material circumstances or social injustice. The neatly balanced parallelism 
of the passage describing the suffering of the rich and the poor, of those who are dependent on others and equally those who provide them with patronage, of those who conform to the norms of society and those who wish to break out of them, points to a perception of suffering as something inherent in the human condition, irrespective of one's place in the social hierarchy.

The text suggests that this condition can be transcended only through a recognition of the deluded nature of all worldly engagement. The catalog of calamity and destruction in Hojoki serves to highlight the transience of human life and possessions, the realization of which paves the way for the rejection of worldly life in favor of religious reclusion. This deployment of the theme of human suffering in the service of the reclusive ideal sets Hojoki apart from Chiteiki. In Hojjoki, the dwelling becomes a metaphor for worldly attachments to be cast off. In Chiteiki, the home does not suggest ephemerality; ideally it takes on the solid and essentially social Confucian attributes of benevolence, righteousness, and frugality.

\section{Chōmei's Ten-Foot-Sguare Hut}

In Hōjōki Chōmei recounts his transition from living in his ancestral home to building a modest cottage for himself to leaving the capital altogether, eventually retreating into a ten-foot-square hut. After several years living in the house of his paternal grandmother, around the age of thirty he had had to leave his ancestral home as a result of hard times. At this point Chōmei had chosen to build himself a house that was barely one-tenth the size of his earlier dwelling. Then, having borne the hardships of the impermanent world for thirty years, he decided to leave his home and the capital to become a priest. In Chomei's progress toward casting aside worldly attachments, becoming a priest is clearly a major landmark. However, the first five years after taking the tonsure are ones that Chōmei is loathe to discuss. All that appears in Hōjōki is the cryptic question, "How many years had I vainly spent in the cloud-covered hills of Ōhara?" 186 The move to the ten-foot-square hut took place after this period in Ōhara, when Chōmei was sixty years old. Borrowing almost verbatim from Chiteiki, Chōmei likens his decision to fashion a hut for his last years to that of the

186. HK, 29; Keene, "An Account of My Hut," 197. 
traveler who has found an inn along the road or of an old silkworm who has made himself a solitary cocoon (HK, 30).

Chomei then goes on to explain that his ten-foot-square hut was not even a hundredth the size of the house in which he had spent his middle years. By drawing a correspondence between the progressive shrinking of his dwelling and his own advancing age, Chōmei implies his own natural progression from attachment to detachment.

To point to the inconsequential and impermanent nature of his worldly possessions, Chomei stresses the smallness of his hut and its portability. (It was built with hinges and could be dismantled on short notice and put up in a new place, rather like a tent). To emphasize further his lack of concern with stability and security, he points out that he did not specially choose a spot to set up his hut and that he did not think of any piece of land as his own possession. The modesty of the dwelling brings with it a certain freedom-a freedom that is celebrated in Hōjoki. If there was anything that he found displeasing, he could easily move his hut $(H K, 30)$.

This description of the physical dimensions and outward aspect of his hut is followed by an account of its interior. As inside Yasutane's pond pavilion and Po Chü-i's thatched hall, the division of the physical space within the hut corresponds to the two spheres of activity that Chōmei prizes most highly and that define his existence as a recluse.

The west, being the direction of the pure land, is where he places his Buddhist materials, such as his images of Amida and of Fugen and his copy of the Lotus Sutra. To the east he has his bed, which is made of stacks of fern and is therefore entirely makeshift, suggesting Chōmei's total lack of interest in material comforts. In the southwestern corner of the room he places objects whose iconographic weight equals that of his Buddhist materials: books on poetry and music and musical instruments such as the koto and the biwa. Here he also places a copy of $\overline{o j o y} \bar{o} s h \bar{u}$ (Essentials of Salvation).

$\bar{O} j \bar{o} y \bar{o} s h \bar{u}$ is a compilation of the sayings of the priest Genshin, said to have been put together in 985 . It is interesting that among his works on poetry and music Chomei chooses to place a text that belongs properly to the religious realm. $\bar{O} j \bar{o} y \bar{o} s h \bar{u}$, however, unlike the Lotus Sutra, which was a highly respected official Buddhist text, was a derivative text, a Japanese reinterpretation of the Buddhist teachings written only 170 years before Chōmei's 
birth. Perhaps for this reason it occupied a place among the more intimate and personal collection of Chōmei's favorite literary works and musical instruments.

The final section of Höjōki stands in stark contrast to the conclusion of Chiteiki. Yasutane acknowledges the dichotomy between the body and mind but maintains that the two, while engaging in different pursuits, can coexist without conflict. He sees no reason to abandon one for the other-the two do not interfere with each other as long as he can maintain the autonomy of his mind, which even while living in the world can be detached from it. The text ends on a note of harmony.

In Chomei's writings too, the distinction between the body and the mind is a crucial one, and it is clear that for him the mind is the domain that can be trained and harnessed to the Buddhist cause. The body, by contrast, is the seat of deluded attachment and must not be indulged. In Hōjōki, however, he expresses reservations about the mind itself, and the harmonious coexistence of worldly and religious activities is eventually called into question through a dialogue between Chomei and his other self, that is to say, between his two minds. Thus, while Chiteiki ends on a note of harmony, Hōjōki provides no resolution.

\section{Chōmei's Life as a Sukimono}

After a description of the contents of his hut, Chömei moves on to an account of his daily activities on Toyama at Hino. He writes:

When I do not feel like reciting the nenbutsu and cannot put my heart into reading the sutras, no one will keep me from resting or being lazy, and there is no friend who will feel ashamed of me. Even though I make no special attempt to observe the discipline of silence, living alone automatically makes me refrain from the sins of speech; and though I do not necessarily try to obey the commandments, here, where there are no temptations, what should induce me to break them?

On mornings when I feel myself short-lived as the white wake behind a boat, I go to the banks of the river and, gazing at the boats plying to and fro, compose verses in the style of the priest Mansei. Or if of an evening the wind in the cassia trees rustles the leaves, I recall the river at Jin'yo and play the lute in the manner of Minamoto no Tsunenobu. If still my mood does not desert me, I often tune my lute to the echoes in the pines, and play the "Song of the Autumn Wind," or pluck the notes of the "Melody of the Flowing Stream," modulating the pitch to 
the sound of the water. I am but an indifferent performer, but I do not play to please others. Alone I play, alone I sing, and this brings joy to my heart. ${ }^{187}$

Chōmei presents himself as moving freely from religious practice to artistic pursuits, with one following the other naturally, without any sense of contradiction or tension. Running through this entire passage is a sense of liberation from the norms and rules that govern the lives of people who function within society, even those who have chosen religious vocations and live in monastic institutions. Chōmei proclaims that he does not have to force himself to recite the sutras or Amida Buddha's name if he feels disinclined to do so. He can allow himself the liberty of resting or doing nothing at all, without having to face the critical gaze of the world.

As if in anticipation of criticism, Chōmei defends himself by saying that he does not need to specially perform religious practices because his life-style itself enables him, in the most natural manner, to lead a life in harmony with the Buddhist dharma. The full resonance of this passage can only be appreciated in relation to Chōmei's descriptions in Hosshinshū of ideal sukimono who live, quite unselfconsciously, in tune with the way of the Buddha.

By defending his own rather idiosyncratic approach to traditional Buddhist practices, Chōmei paves the way for a justification of his engagement with poetry and music. When he says that he does not go out of his way to observe the religious injunctions because the life he leads ensures that he does nothing to break them, he has in mind not only his physical isolation from society and its corrupt practices, but also his involvement in artistic practices that he claims are deeply consonant with the religious life.

As we have seen, Chōmei singles out poetry in particular as a religious practice par excellence in many of his stories in Hosshinsht. In explicating why poetry deserves to be accorded a special place as a religious practice, he writes: "How much more so then, because the way of poetry is one that can penetrate to the essence of things, can we depend on it and, through this medium, calm the mind and meditate on the transience of all worldly things" (HS, 276).

187. HK, 32; Keene, "An Account of My Hut," 199. I have modified Keene's translation by changing "the wind in the maples" to "the wind in the cassia trees" as this is closer to the original. As I argue, Chomei's choice of the word "cassia" in this context is significant. 
The priest Hōnichi, eulogized in Hosshinshū, made the recitation of poems at dawn, noon, and dusk his three religious practices of the day in the firm belief that this was the way to meditate on the transience of life (HS, 275-76). For Chōmei, poetry is inseparably linked with a deep awareness of the ephemerality (mujo) of all worldly things. By Chomei's times, Japanese poetry was suffused with the aesthetics of mujo, especially in poems on the changing seasons and on nature in general. Litterateurs of this period saw mujō as a fundamental Buddhist principle whose spirit was best captured and understood through poetry. Thus, in Hōjōki, when Chomei reflects on the ephemerality of his own condition, he conceptualizes it in poetic terms. He has the poem by the priest Mansei in mind when he likens himself to the white ripples that appear fleetingly on the water's surface as the boats ply the lake. Gazing at the boats going to and fro from Okonoya, he puts himself in the same mood as Mansei and recites in his style.

In this kind of engagement with poetry we can identify a number of stages. Chōmei begins with what he regards as a fundamental Buddhist premise-ephemerality. An awareness of this principle is brought home to him through the medium of poetry. Once he is conscious of his own temporality through Mansei's poem, Chomei recites the poem itself. An understanding of the Buddhist principle of mujo is thus rendered inseparable from its poetic conception, and the two are brought together through the formal utterance of the poem itself.

It is not without significance that this very poem by Mansei is said to have converted Genshin to the belief that "the sacred teachings and Japanese poetry are in fact identical." This anecdote appears in Hosshinshu, and clearly Chōmei has it in mind when he gives this poem a special place in his account of life as a recluse (HS, 276-77). Whether or not the readers of Hōjōki had access to Hosshinshū, Chōmei's re-creation of Genshin's experience sharpens a polemic he is constantly engaged in, even when it is not explicitly stated, namely, the question of the compatibility of an involvement in poetry with the attempt to lead the life of an exemplary Buddhist.

While the white waves of Okonoya evoke the memory of the poem by Mansei, the rustling of the leaves in the cassia trees (katsura) takes Chōmei to China and reminds him of the estuary of Junyang (Jin'yō) in Po Chü-i's famous poem, the "Song of the Lute." 188

188. Rewi Alley, trans., Bai Juyi, 200 Selected Poems (Beijing: New World Press, 1983), 232-36. 
The poem is a sad account of the faded glories of a talented lute player who lived in Chang'an and was highly sought after for her beauty and her artistic accomplishments. Po Chü- $i$, who is in exile, encounters her in Junyang, where she now lives alone as her husband, a trader "whose mind was only on profits and who thought little of separation," is away on business. Po Chü-i and the lute player share their longing for the cultured life of the capital, in which refined music played a central part. The poem is a wistful and nostalgic evocation of a past that can never be recaptured.

Po Chü-i's poem evokes for Chōmei associations between cassia trees and the lute, which lead him to shift from poetry to music. Chomei explains that he plays the lute in the style of Minamoto no Tsunenobu, a famous poet and musician, also known by his sinicized name Gen Totoku. He was the grandfather of Chomei's poetry teacher, Shun'e, and established himself in the artistic world with his mastery of the lute and his founding of the Katsura style of music. Chōmei himself was the disciple of Nakahara Ariyasu, who had mastered Tsunenobu's style. Chōmei could thus trace his musical lineage to Tsunenobu through Ariyasu, Bichō no Ama, and Mototsuna. Chomei chooses the compositions of Minamoto no Tsunenobu because the Japanese reading of the character for "cassia tree" in Po Chü-i's poem is katsura.

As we mentioned earlier, in Hosshinshū Chōmei claims that music, like poetry, is an important religious practice. It is no coincidence that in Hosshinshü Tsunenobu's teacher, Daini no Sukemichi, is the exceptionally talented biwa player who refused to have anything to do with customary Buddhist practices, instead transferring the number of his biwa recitals to his accumulated merit. ${ }^{189}$ Thus, when Chomei speaks of emulating the lute (okonai) of Tsunenobu, it is reasonable to assume that he means not only musical style (one of the meanings of okonai) but also music as a religious practice (okonai in the Buddhist sense of the term).

Chömei then proceeds to describe how, when he feels inclined to play more music, he performs the "Song of the Autumn Wind" or the ryüsen "Melody of the Flowing Stream." The autumn breeze melody was a piece of gagaku music that originated in China in the T'ang period. In Japan it came to be identified with the music that welcomed the dead to Amida's western paradise. Chōmei's performance of the ryūsen, which was a secret melody, acquires a special significance in the altered context of his life as a recluse. According to the musical treatise Bunkidan, it was 
Chōmei's performance of another secret melody, the takuboku, while still at court, that led to his disgrace and to his decision to take the tonsure. ${ }^{190}$ We have discussed this account at length earlier, but several aspects of this episode are worth restating for what they tell us about Chomei's decision to represent himself as playing the ryusen in seclusion.

According to Bunkidan, Chōmei had received instruction only in the secret melody called the yoshinsō. Chōmei's passionate involvement with music led him to invite several well-known musicians to the Kamo shrine, and it was there that the incident that came to be called "playing the secret melody" (hikkyoku zukushi) took place. Fujiwara no Tadamichi, at that time in charge of the Department of Music (gakusho azukari), complained to the emperor Go-Toba and demanded that Chomei be punished for his singular disregard for the hallowed traditions of the way of music. Bunkidan concludes that this was what forced Chomei to leave the capital and follow the way of religion.

Chōmei's defense of his actions as narrated in Bunkidan is illuminating. He admitted to having played the takuboku but claimed that his extreme commitment to the way of music led him to this grave error. Whether or not this incident actually took place, it is interesting that such a story found its way into the musical lore of the thirteenth century. Chomei's performance of the ryūsen (a secret melody that ranked higher than the yoshinso) while in Hino has resonances with the incident reported in Bunkidan. However, in this instance, the literary act of inscribing this transgression into the text permits Chōmei to subvert courtly conventions and to follow the dictates of his own heart. As Chōmei himself puts it, "Alone I play, alone I sing, and this brings joy to my heart."

Only by isolating himself from society is Chōmei able to pursue his highly individualistic path to enlightenment, one in which artistic and religious practices can coexist in harmony. Although in Hojjoki there is no explicit mention of the ideal of suki, in describing his life and activities as a recluse, Chōmei presents himself in a way that closely approximates the ideal sukimono of Hosshinshu. He finds no pleasure in mingling in society and lives alone in seclusion; he glorifies the simplicity of his dwelling and the self-sufficiency that his straitened circumstances allow him; he lives in close contact with nature and through music and poetry articulates the truth that nature reveals to him, namely, the transience of the world.

190. Wada, Bunkidan, 5-8. See chapter two, pp. 60-62. 
When Chōmei speaks of his activities on Toyama, he clearly sees in the conjunction of nature, music, and poetry the ideal conditions that are conducive to the attainment of enlightenment. This can be seen in his descriptions of his physical surroundings and his own response to them. He writes:

In the spring I see waves of wisteria like purple clouds shining, bright in the west. In the summer I hear the cuckoo call, promising to guide me on the road of death. In the autumn the voice of the evening insects fills my ears with a sound of lamentation for this cracked husk of a world. In winter I look with deep emotion on the snow, piling up and melting away like sins and hindrances to salvation. ${ }^{191}$

The beauty of the wisteria blossoms is heightened for Chomei because they resemble the purple clouds on which Amida Buddha is said to appear when he descends to welcome human beings to the pure land. Similarly, in the cicada's cry Chōmei hears the lamentation of all human beings over the essential frailty of worldly existence. Likewise, the sight of the snow falling on the ground and melting away is an occasion for Chomei to reflect on the sins arising out of delusion that obstruct the entry of human beings into the pure land.

In describing the pleasures that the various seasons bring, Hōjōki draws on the following passage from Chiteiki :

In particular, in spring I have the willows on the eastern bank, misty and lithe; in summer, the bamboo by the northern gate through which the clear breeze rustles; in autumn there is the moon in the western window, bright enough to read a book by; and in the winter the sun shines through the southern eaves, just right for warming my back. ${ }^{192}$

Yasutane's relaxed and almost feline enjoyment of his physical surroundings stands in contrast to Chōmei's conscious effort to find Buddhist imagery in nature. In the passage quoted above, Chomei does more than speak about the beauty of the wisteria blossoms or of the melodious singing of the cuckoo. Here nature and religion are integrally linked, and nature is the visual, symbolic representation of various aspects of the Buddhist truth. The

191. HK, 31-32; Keene, "An Account of My Hut," 199.

192. Chiteiki, 423; Watson, "Record of the Pond Pavilion," 61-62. 
association of natural images with Buddhist principles had become an important part of poetic practice in Chōmei's time. His deep engagement with Japanese poetic traditions shaped his response to the physical world around him.

The parallel between the wisteria and the purple clouds of the pure land, for instance, was a well-established trope in waka. So too, the notion that the cuckoo's song signified a promise to guide human beings to the world of the dead was part of popular lore and was the theme of one of Saigyō's poems in his famous collection, Sankashü. ${ }^{193}$ Chōmei's allusion to Saigyō's poem is a striking instance of the way in which his interpretation of the scenes around him is molded by poetry, whose hallowed traditions provide the language for his articulations.

The analogy that Chomei draws between the piling up of the snow and human $\sin$ is also one that had already been given a place in the Japanese poetic tradition. In Shüi wakashu, for instance, Tsurayuki writes:

Toshi no uchi ni Tsumoreru tsumi wa Kakikurashi Furu shirayuki to Tomo ni kienamu
As the old year passes

May the sins that had piled up Also come to an end And like the falling snow Melt away. ${ }^{194}$

In another richly allusive prose passage in Hojooki, Chömei describes the solitude of the evenings on Toyama and the wistful beauty of his surroundings. Much of the dense texture of such passages derives from an elaborate play on Chinese and Japanese poetic conventions. The concern to give these images a Buddhist underpinning, which dominates some of the other sections of Hojojki, is sometimes put aside for the sheer pleasure of the literary play that Chomei the aesthete seems to delight in. He writes:

193. Matsushita Daizaburō, Zokukokkataikan (Tokyo: Kadokawa Shoten, 1958), no. 7743,111 . Saigyō's poem reads:

Kono yo ni te

Katarai okamu

Hototogisu

Shide no yama michi no

Shirube to mo nare
While still in this world,

Promise me

Oh cuckoo,

That you will be my guide

On the mountain road of death.

194. Matsushita and Watanabe, Kokkcataikan, no. 258, 59. 
If the evening is still, in the moonlight that fills the window I long for old friends or wet my sleeve with tears at the cries of the monkeys. Fireflies in the grass thickets might be mistaken for fishing lights off the island of Maki; the dawn rains sound like autumn storms blowing through the leaves. And when I hear the pheasants' cries, I wonder if they call their father or their mother; when the wild deer of the mountain approach me unafraid, I realize how far I am from the world. And when sometimes, as is the wont of old age, I waken in the middle of the night, I stir up the buried embers and make them companions in solitude.

It is not an awesome mountain, but its scenery gives me endless pleasure regardless of the season, even when I listen in wonder to the hooting of the owls. How much more even would the sights mean to someone of deeper thought and knowledge! ${ }^{195}$

Throughout this passage Chomei evokes the poets of the past and through his allusions pays homage to their writings. ${ }^{196}$ For instance, the first line of the above passage alludes to a poem by Po Chü-i in which the latter writes:

As I see the color of the moon

Rising in the eastern sky

Of an evening on the fifteenth day of the month,

I am filled with memories of my friends of old

Who live three thousand leagues away from me. ${ }^{197}$

Like many other poems by Po Chü-i, this verse had been popularized in Japan through its inclusion in Wakan rōeshū, and Chōmei's contemporaries would have instantly identified his allusion.

In speaking of the cry of the pheasant, Chomei harks back to the following poem by Gyōgi:

Yama dori no
Horo horo to naku
Koe kikeba
When I hear

The pheasant cry

Horo horo,

195. HK, 34; Keene, "An Account of My Hut," 200.

196. I have mentioned only a few examples of the intertextual mode at work in this section. For a more detailed discussion of the rich mosaic of allusions embedded in this passage, see Marra, Aesthetics of Discontent, 97-98.

197. Ōso and Horiuchi, Wakan rōeishū, 95-96. 
Chichi ka to zo omou I wonder-is it my father?

Haha ka to zo omou Is it my mother? ${ }^{198}$

Similarly, to express his sense of isolation, he renders in prose the following poem by Saigyō:

Yama fukami
Naruru kasegi no
Kejikasa ni
Yo no tōzakaru
Hodo zo shiraruru
The wild deer

Who approach me without fear In the depths of the mountain Bring home to me How far I am from the world. ${ }^{199}$

The allusions to poems by paragons such as Po Chü- $\mathrm{i}$ and Saigyo enhance the authenticity of the aesthetic experience. On occasion, an allusion to the literary canon serves to indicate difference. Thus, when Chōmei speaks of nature as a companion of whom he never tires, he does so by inverting the harshness of the relationship between man and nature that Saigyō expresses in this poem:

\author{
Yama fukami \\ Kechikaki tori no \\ Oto wa sede \\ Mono osoroshiki \\ Fukuro no koe
}

In the mountain depths

I do not hear the songs

Of the birds I am familiar with.

The eerie cry

Of the owl alone reaches my ear. ${ }^{200}$

Chömei's claims that the mountain holds no fear for him and that he finds even the hooting of the owl strangely moving reinforce his position that a life of reclusion is one of unfettered freedom and pleasure.

It is no coincidence that in describing the pleasures of such a life Chōmei has as his models men like Gyōgi and Saigyō, the most respected of Japan's religious peregrinators. ${ }^{201}$ The life of seclusion, in which nature, poetry, and music played a central role, was specially favored by such recluses (intonsha, tonseisha). These hermits, whom Mezaki Tokue describes as suki no intonsha, sought to escape the constraints of the court as well as of institutionalized Buddhism and believed that Buddhist doctrine could be intuited through a heightened sensitivity to the natural world

198. Matsushita and Watanabe, Kokkataikan, no. $2614,418$.

199. Matsushita, Zokukokkataikan, no. 8202, 120.

200. Ibid., no. $8198,120$.

201. For a study of the close link between nature and Buddhism in the poetry of Saigyō, see William LaFleur, "Saigyō and the Buddhist Value of Nature," History of Religions 13.2 (November 1973): 93-128; 13.3 (February 1974): 227-48. 
and through the serious cultivation of poetry. ${ }^{202}$ They were the figures who corresponded most closely to the ideal sukimono envisaged by Chōmei in Hosshinshü.

In the passage quoted earlier, after describing the sights and sounds, Chomei concludes, "How much more even would the sights mean to someone of deeper thought and knowledge!" Those with "deeper thought and knowledge," claims Chōmei, will better grasp the profound truth of the dharma, which is inherent in the world of nature. The apprehension of what lies at the heart of nature finds its expression, above all else, through the medium of poetry. Thus, it is poetry that renders transparent the Buddhist truth that is hidden within the sights and sounds of nature: its appreciation and appropriation must be mediated through poetry, to the degree that poetry and nature can be separated at all. It is therefore nature/poetry that becomes the site for gaining the profound religious insights that Chomei claims he has failed to grasp.

Through close contact with nature and the cultivation of music and poetry, Chōmei envisions the possibility of escaping from the sin of worldly attachment and of achieving a state of mind conducive to enlightenment. As pointed out earlier, this vision of enlightenment finds its expression in the ideal of the sukimono, which Chōmei develops in Hosshinshü; as we shall see, however, the conclusion of Hojojki, which has been the subject of so much controversy, calls into question precisely this idealized vision of the recluse-aesthete.

\section{THE Conclusion OF HŌJŌKI}

In the last section of $H \overline{o j} \bar{o} k i$, Chōmei returns to the question of attachment and reviews his claim that his own life in his ten-footsquare hut has somehow freed him from worldly concerns. The hut reemerges as a metaphor for attachment, and Chōmei acknowledges that he cannot dispense with the problem of attachment merely by invoking the size of his dwelling. He dismisses his own involvement with his hut and with music and poetry as a "trifling pleasure" that he has wasted precious time recounting.

The interpretation of this section is a central concern for scholars working on Hōjoki, and thus the concluding passage is worth reproducing in full:

202. Mezaki, "Aesthete-Recluses during the Transition from Ancient to Medieval Japan," 153. 
Now the moon of my life sinks in the sky and is close to the edge of the mountain. Soon I must head into the darkness of the Three Ways: why should I thus drone on about myself? The essence of the Buddha's teaching to man is that we must not have attachment for any object. It is a sin for me now to love my little hut, and my attachment to its solitude may also be a hindrance to salvation. Why should I waste more precious time in relating such trifling pleasure?

One calm dawning, as I thought over the reasons for this weakness of mine, I told myself that I had fled the world to live in a mountain forest in order to discipline my mind and practice the Way. "And yet, in spite of your monk's appearance, your heart is stained with impurity. Your hut may take after Jömyō's [Vimalakirti's], but you preserve the Law even worse than Handoku. If your low estate is a retribution for the sins of a previous existence, is it right that you afflict yourself over it? Or should you permit delusion to come and disturb you?" To these questions my mind could offer no reply. All I could do was to use my tongue to recite two or three times the nenbutsu, however unacceptable from a defiled heart [fushō no amida butsu ryösanben möshite yaminul.

It is now the end of the third moon of 1212 , and I am writing this at the hut on Toyama. ${ }^{203}$

The positions that Japanese scholars have adopted with regard to this passage have been guided, for the most part, by their particular ideological preconceptions. Buddhist scholars, on the one hand, have analyzed Hojoki to gauge the degree to which Chōmei passes the test of being a good Buddhist. Some have expressed disappointment at Chōmei's inability to attain to the Buddhist ideal of enlightenment, a failure they see reflected in his tortured self-interrogation at the end of the work. Others take the opposite view and argue that Chōmei was in fact an enlightened recluse who merely used his narrative as an expedient means to point to the transcendence of the Buddhist way. Kokugakusha scholars, on the other hand, see Chōmei as a litterateur steeped in the aesthetic traditions of the court. They suggest that whatever the nature of Chōmei's religious aspirations, his writings are, first and foremost, great works of literature that are assured a secure place within the Japanese literary canon.

Perhaps the most important of the Buddhist scholars is Yamada Shozen. He argues that in Hōjōki the central tension is 
between one Chōmei who possesses an enlightened mind and another Chōmei whose mind is still steeped in deluded thoughts. The enlightened mind criticizes the other Chomei, who is absorbed with his natural surroundings and has a highly aestheticized response to his life of solitude. The deluded mind, when faced with this criticism, is unable to offer a satisfactory defense of its own position. Yamada points out that earlier in Hōjōki, Chōmei constantly draws a distinction between the body $(m i)$ and the mind (kokoro). The contradiction between the two is resolved for him by leaving the capital and leading a life of simplicity in which the mind, that is to say, the spiritual aspect of his life leads and directs the workings of the body, which is driven by worldly desires. It is in Hino that his body and mind for the first time achieve a harmonious coexistence.

However, toward the end of $H \overline{o j} \bar{o} k i$, a new dichotomy emerges within the mind itself. His enlightened mind accuses his deluded mind of having colluded with his body and sought comfort in "trifling pleasure," and of enjoying solitude in and of itself rather than as an environment conducive to the attainment of enlightenment. Yamada sees Chömei's recitation of the nenbutsu as a reflection of this struggle. He argues that the enlightened self is given a superior position by Chomei, but the deluded self does not abandon its recalcitrant position entirely. This, in Yamada's reading, is the significance of the word yaminu (I stop; I become silent), with which Chōmei ends Hōjōki. Chōmei falls silent after reciting the nenbutsu only two or three times and is unable to recite Amida's name ten times, as is prescribed in the teachings of Hōnen. For Yamada this results from a conflict between the two minds that is never successfully resolved because of Chomei's resistance to the doctrine of tariki (other-power), which urges reliance on Amida Buddha. ${ }^{204}$

The phrase fusho no amida butsu has generated considerable hermeneutical dispute and is one that Yamada deals with at length in another article. ${ }^{205}$ By pointing to an impressive array of sutras and other religious texts, Yamada seeks to establish that fushō was a common epithet for the Amida Buddha and signified his pledge to save human beings even without their praying for it

204. Yamada Shōzen, "Futari no Chōmei: Hōjōki kara Hosshinshū e," Kokubungaku tōsa 2 (March 1973): 56-64.

205. For a detailed account of the debates, see Miki Sumito, "Hōjōki no mappi," in Kōza Nihon bungaku no sōten, Chūsei, vol. 3 (Tokyo: Meiji Shoin, 1969), 352-58; and Yanase Kazuo, Hōjōki kaishaku taisei (Tokyo: Taishũkan, 1972), 246-57. 
themselves. The implication is that even with Amida's helping hand extended toward him without his asking, Chōmei is unable to surrender to it completely. ${ }^{206}$

For Yamada, the order in which Hōjōki and Hosshinshū were composed is integral to an understanding of Chōmei's position. He argues that Hōjōki had to be written before Hosshinshü, because in the preface to the latter work, Chomei begins with the premise that the mind needs to be tutored and guided and must not be allowed to follow its own inclinations. Claiming that it would be foolish to rely on one's own mind, Chōmei invokes the Buddhist injunction that we should become masters of our own minds and not make our minds our masters. According to Yamada, in Hosshinshū, Chōmei resolves effectively the contradiction between the deluded mind and the enlightened mind that had troubled him toward the end of Hōjōki. Hosshinshū, Yamada holds, follows from the insight that Chömei gained from the self-introspection that led to the writing of Hōjoki.

Yamada concludes, however, that even in Hosshinshü Chomei is unable to transcend the duality of the two selves that he recognizes within himself. This, he suggests, is because Chōmei fails to cast aside his own ego, which Yamada calls "his third self." Yamada believes that Chōmei's unconscious ego is present in all of his endeavors since he never forsakes his literary activities, which by their very nature stem from the "I."

Imanari Genshō, although writing from within the Buddhist hermeneutical framework, takes an approach that differs considerably. As discussed earlier, he argues that Hōjoki is a cleverly constructed work in which Chömei intentionally plays on the structural affinities between Hōjōki and the Vimalakirti Sutra in order to produce a profoundly Buddhist work. Chōmei's elaborate descriptions of the pleasures of a solitary life in the midst of nature are, according to Imanari, an expedient means used to illustrate the profundity of the doctrine of nonduality.

In support of his argument, Imanari points to the close parallel between the structure of one story in Hosshinshu and that of Höjōki, in which Chōmei again uses the concept of expedient means to teach the ultimate truth. In Hosshinshü, Chōmei narrates a

206. Yamada Shōzen, "Fushō Amida Butsu zairon: Hōjōkki kesshōbun no kaishaku," Taishō daigaku kenkyū kiyō 65 (1979): 127-49. For a detailed discussion of the wide range of hermeneutical disputes centered around the term fushō, see Hare, "Reading Kamo no Chōmei," 199-203. 
story about a destitute man who is forced to take shelter in broken-down temples (HS, 236-39). He spends his days begging for paper and writing implements, with which he sketches houses, thus constructing different kinds of dwellings on paper. This is a source of great comfort to him. Chōmei praises him, saying that his activity is better than that of people who spend their lives building homes only to see them destroyed because at least it prevents him from experiencing grief and disappointment. Also, compared with the worldliness of those who are preoccupied with possessing luxurious homes, his architectural obsessions, being in the realm of the imaginary, are much more laudable. However, in the conclusion to the story, Chōmei points out that instead of wasting one's last days in pointless expectations, it is much more meaningful to turn one's thoughts to the Buddha and to aspire instead to the splendid mansions of the pure land. In the end the houses sketched by the poor man, unworldly though they may be, are nothing but attachments, ephemeral aspirations without any substance.

According to Imanari, when Chōmei describes his own pleasure in living in a small hut, he is deliberately enacting the role of the poor man who is fond of sketching buildings. At one level, the simplicity of Chomei's dwelling and of his little pastimes is more commendable than the worldly concerns and ambitions of those who live a privileged life within society. Yet, for all that, Chomei's love for his hut is nothing but a form of deluded attachment. Chōmei's final solution, says Imanari, is reliance on Amida Buddha and a recognition of the truth of nonduality encapsulated in Vimalakīrti's final response of total silence. ${ }^{207}$ Chōmei's use of the word yaminu to conclude Hōjoki is, according to Imanari, a selfconscious echoing of Vimalakirti's silence, pointing to the fact that ultimate truth lies beyond the realm of words.

For Kishi Shōzō, a scholar in the kokugaku tradition, it is the tension between a Chōmei committed to the ideal of suki and a Chomei aspiring to the Buddhist path that is reflected in the final passage of Hōjōki. Kishi argues that although Hosshinshü is often seen as more directly motivated by a religious commitment and therefore as having been written after Höjokki, this does not explain the presence in Hosshinshu of the idealized sukimono central to a number of the stories. He also argues that Hosshinshu was written prior to $H \overline{o j} \bar{o} k i$, and he sees the stories about sukimono in Hosshinshü as the inspiration for the life that Chōmei attempts 
to lead on Toyama. Hōjōki, according to Kishi, represents the culmination of Chomei's aspiration to the ideal of suki, and, for all the self-criticism of the last section, it is an ideal that Chomei is reluctant to give up.

Through a study of literary texts written in both Japanese and kanbun, Kishi suggests an interpretation of the term fushō that is widely divergent from the one offered by Yamada. He puts forward the view that the Japanese reading of the characters is ukezu (unable to accept) and thus that in this context it alludes to Chomei's grudging recitation of the nenbutsu even when he does not feel inclined to do so. ${ }^{208}$

Both Yamada and Kishi, despite their differences, see the last passage of Hōjōki as a reflection of a conflict within Chōmei that he is in the end unable to resolve. For Kishi this tension arises out of Chōmei's involvement with artistic activities, his desire to be the ideal sukimono while at the same time being committed to the Buddhist path. Yamada, however, analyzes Chōmei's struggle in Buddhist terms: Chōmei's inability to achieve liberation from the ego, the self, ultimately prevents him from attaining the enlightened state to which he aspires. Both scholars work on the premise that toward the end of Hōjōki Chōmei arrives, unexpectedly, at the realization that he has not adequately come to terms with his life as a recluse and that he has failed to transcend the problem of attachment that was the impetus for his move to a life of seclusion.

Imanari, in contrast, sees Hōjöki as a cleverly constructed text that seeks to prove the ultimate superiority of the doctrine of nonduality through a contrived posturing. Chōmei allows the reader to see his devotion to the pleasures of his natural environment, his simple abode, his music, and his poetry, and then destroys this edifice of mock detachment by turning it on its head and revealing it to be as deeply steeped in attachment as life in the secular world. Imanari demonstrates that the architectonics of $H \overline{o j} \bar{o} k i$ closely parallel those of the Vimalakirti Sutra, and he sees Chōmei's choice of a highly aestheticized life in which music and poetry play a major role as a kind of contrived polemic designed to illustrate the Buddhist truth.

The compelling nature of these diverse readings attests to the complexity and richness of Hōjōki as a literary text. Hosshinshū,

208. Kishi Shōzō, "Hosshinshū kara Hōjōki e," Kokugo to kokubungaku (March 1978): 1-13. 
through the idealized sukimono, seeks to resolve the tension between attachment to the material world and the goal of renunciation. Hōjokki focuses more directly on the nature of attachment and posits the idealized reclusive life as a solution. In the conclusion to the text, however, it points to the difficulty of transcending attachment as the hut itself becomes a source of pleasure.

However, embedded within the pages of Hojoki is another site of pleasure: this is the pleasure derived from music and poetry, performed or recited without restraint, outside the confines of courtly rules and etiquette. A significant portion of Hōjoki engages in an elaborate virtuoso performance in which, through the richly textured references to other texts, an idealized vision of the aesthetic life is constructed.

The text draws attention to itself as an elaborate literary artifact that consciously displays literary prowess. The artistic values that animate this text, indeed that are paraded in it, are brought into question at the end, however. The accusation Chomei levels against himself is that he has failed to comprehend the teachings of nonduality and that he is no better than Handoku (Cūdapanthaka), the most foolish of Buddha's disciples, while all the time imagining himself to be Jōmyō (Vimalakirti). In signaling his own failure, the narrator is conceding that aesthetic practices belong to the realm of deluded attachment and thus impede a true immersion in the way of the Buddha. Or is the source of lament rather the inability to attain to the ideal of suki, which presupposes an understanding of the harmony between artistic and religious practices?

If we read Hōjōki in conjunction with Hosshinshū rather than treat one as a development of the other (a reading further complicated by divergent theories about the order in which the two texts were composed), the life of the recluse as portrayed in Hojoki is remarkably reminiscent of that of the sukimono in Hosshinshu, who comprehends the true meaning of nonduality and assumes from the outset the identity of artistic and religious practices.

Chomei describes the sights and sounds that he experiences in nature and articulates his own response through a series of allusions to poems by well-known poet-priests like Saigyō and Gyōgi, thereby opening up possibilities for those committed to the Buddhist path by saying, "How much more even would these sights mean to someone of deeper thought and knowledge!" There is a suggestion here that there were, within the Japanese tradition, 
religious recluses who had indeed achieved a harmony between art and religion. He contrasts his own failure to achieve this with the example of such figures as Saigyo, who successfully integrated artistic and religious practices. Chōmei's literary persona, to which Gyōgi and Saigyō serve as foils, keeps the debate on art and enlightenment in Hojjoki an open-ended one. 


\title{
Appendix One
}

\author{
The Kamo no Chōmei Incident \\ (An Excerpt from Minamoto Ienaga nikki)
}

People who devote themselves to any one thing, no matter how inconsequential, are bestowed with extraordinary favors by the emperor. And yet, Chōmei failed to realize his aspirations! This, I have been told, is entirely because of his karma from previous lives.

Anyhow, this person Kamo no Chōmei, after becoming an orphan, ceased to take part in affairs relating to the shrine and lived in seclusion. But because of his reputation in the field of poetry, he was summoned by the emperor, and he soon became an official at the Bureau of Poetry. From that time onward he would take part in all functions relating to poetry and would compose poems at all the regular poetry contests. He never left the bureau and worked there day and night with the greatest diligence.

Just around the time when the emperor was contemplating rewarding Chomei should some appropriate occasion arise, the post of head official [negi] fell vacant at the Lower Kamo shrine. Everyone was convinced that this time the emperor would ensure that Chōmei got the post.

Even before Chōmei had expressed his interest in this appointment, it looked very much as though it would be his. When this rumor reached Chomei's ears, he appeared unable to control his tears of joy.

The head of the Lower Kamo shrine at the time, Sukekane, heard of these plans and sent the following petition to the emperor:

It is not customary among officials of the shrine to disregard hierarchy based on court rank. My eldest son is junior fifth rank. Although Chomei is older than he is, he has involved himself but little in matters to do with the shrine-this may well be due to his feeling that he is a 
person of no consequence. My son Sukeyori may be a child compared with Chomei, but the way in which he has worked day and night at the shrine far exceeds anything that Chomei has done. Without question, the gods see this clearly. Even if my son's commitment to his duties at the shrine were to be lacking in any way, how could the prayers of his father for the longevity of the emperor go unanswered? It would not do to treat the eldest son of the highest official of the Kamo shrine as one might others. This applies not only to the shrine in question.

Thus he appealed to the emperor in a grandiose manner, claiming that what he had set out was a divine decree. There was nothing special about Chomei's position that stood in his favor. It was just that the emperor, who had, in the first place, summoned him to court because of his excellence in poetry, did not want it all to come to naught. However, even the other officials [who were not related to the shrinel grieved and protested in an uncommon way over the proposed bypassing of the hierarchy of rank for no special reason. The shrine officials went further and insisted that the divine decree of the gods should be accorded first place-and this was only to be expected.

Hearing all this, the emperor felt that everything was in Sukekane's favor. He then decided to upgrade a smaller shrine that was affiliated to the main Kamo shrine, to accord it the same status as the latter, and to create the post of head official for this shrine, to which Chomei could then be appointed.

This was truly a rare and felicitous act on the part of the emperor. I was sure that Chōmei would be delighted, not only at being able to fulfil his desire to become head official, but also at the thought that, because of him, a subsidiary shrine would be elevated to the same position as the main shrine, and that he would in this way contribute to the glory of the Kamo shrine.

However, Chōmei turned down the emperor's offer, stubbornly declaring that he had failed to get what he had wanted in the first place. This made me go so far as to wonder if he was not out of his right mind.

After that I heard that he had gone into total seclusion-no ordinary matter. He did not say where he was, but, after some time had elapsed, he sent fifteen poems that he had composed to the emperor. Among them was the following:

Sumiwabinu

Ge ni ya miyama no

Maki no ha ni
Weary of life, Here deep in the mountains, Must I really behold the moon 
Kumoru to iishi Tsuki o miru beki
Clouded over by the pine trees Of which I had spoken?

When Chōmei had been summoned to the court by the emperor, a poetry contest had taken place, and among the poems that Chomei had composed, the emperor had considered the following poem, written on the topic, "The Moon Deep in the Mountains," particularly impressive:

\author{
Yomosugara \\ Hitori miyama no \\ Maki no ha ni \\ Kumoru mo sumeru \\ Ariake no tsuki
}

All through the night

Alone in the mountain depths I gaze at the moon

Clouded over by the pine needles.

Now at dawn, it shines through clearly.

Everyone remarked that Chōmei's allusion to his earlier poem and his use of the phrase "deep in the mountains must I really" in the poem he sent to the emperor was extremely moving.

However, I could not help feeling that his extremely stubborn temperament would ruin everything. After this, the rumor was that he had taken the tonsure and was quietly carrying on with his religious practices at Ōhara. I felt that he was a person who carried things too far, but Chōmei probably thought of this world as a deluded dream, in which, due to certain karmic links from previous lives, he had been strongly fated to enter the true path.

The emperor asked me to find out if Chomei still had the biwa called tenarai, and so I sent a messenger up to Öhara to make inquiries. Chōmei sent back the lute with the following poems written on the plectrum:

\begin{tabular}{|c|c|}
\hline Kakushitsutsu & Parting with this, \\
\hline Mine no arashi no & In the end only the sound \\
\hline Oto nomi ya & Of the storm \\
\hline Tsui ni waga mi o & On the mountain peaks \\
\hline Hanarezarubeki & Will keep me company. \\
\hline Haraubeki & Here it is \\
\hline Koke no sode ni mo & Still in its dusty state. \\
\hline Tsuyu shi areba & I was unable to wipe it \\
\hline Tsumoreru chiri wa & For the sleeves of my priestly robes \\
\hline Ima mo sanagara & Are drenched in tears. \\
\hline
\end{tabular}

On seeing these, the emperor ordered me to compose some poems in reply, and so I wrote the following verses: 


\begin{tabular}{|c|c|}
\hline Kore o miru & As I look at it \\
\hline Sode ni mo fukaki & My sleeves too \\
\hline Tsuyu shi areba & Are so deeply soaked in tears \\
\hline Harawanu chiri wa & That the unwiped dust \\
\hline Nao mo sanagara & Remains as yet untouched. \\
\hline Yama fukaku & Thinking sadly \\
\hline Irinishi hito o & Of the one who has just entered \\
\hline Kakochite mo & Deep into the mountains, \\
\hline Nakaba no tsuki o & I look at the half-moon- \\
\hline Katami to wa minu & My only memento. 209 \\
\hline
\end{tabular}

After that, when I met him again quite by chance, he had grown so thin and shrunken that I could hardly recognize him. He said, "If I had not deeply resented the society I lived in, the darkness of this fleeting world would not have become illuminated for me." Weeping copiously, he wrung the sleeves of his priestly robes, drenched in tears. He went on, "Although I have cast aside thoughts of worldly life, there is still something that holds me back a little," and, pulling out from his sutra bag the plectrum of the biwa on which I had written the replies to his poems, he added, "Somehow this will accompany me beneath the moss and will decay with my body."

I felt extremely sorry for him when I realized that he found it so hard to forget and reject what he had set his heart upon, and that he was convinced that his attachment would even be a hindrance to the religious path he had taken. ${ }^{210}$

209. The stop on the surface of a biwa is in the form of a half-moon, hence the use of the phrase nakaba no tsuki to mean the biwa.

210. Ishida and Satsukawa, Minamoto Ienaga nikki zenchūkai, 104-5, 109-11. 


\section{Appendix Two}

\section{Selected Translations from Hosshinshū}

\section{2:3 The Imperial Secretary, Priest Jakushin}

During the reign of Emperor Murakami, there was a person who was known as Priest Imperial Secretary Jakushin. From the very beginning, even when he was in the service of the court, his heart longed to follow the Buddhist path. In every situation he displayed the deepest compassion and kindness toward others.

Once he had to leave the Office of Imperial Records and go to the court on official business. When he reached the camp of the outer palace guards, he saw a woman weeping.

When he asked her why she was crying, she replied, "My master had asked me to deliver a leather belt to someone who needed to borrow it. But I dropped it somewhere on the way, and I know that I am going to be severely punished by my master. I feel so bad about having lost this precious object that I see no way in which I can go back to my master. I just don't know what to do."

Jakushin felt sorry for her and empathized so completely with her feelings that he took off the sash that he was wearing and presented it to her.

The woman said, "Although it is not the same as the original one, if I go back with this one, it will be better than returning empty-handed without any excuse; perhaps my offense will be forgiven." Rubbing her hands in a gesture of supplication, she went away happily. ${ }^{211}$

211. This incident appears in virtually the same form in Ima kagami. See Unno, Ima kagami zenshaku, 2:419-20. 
Jakushin had no other sash in his possession, and thus he stayed away from public activities. Just at that time there was an urgent summons from the court, requiring his presence at a function. So he borrowed someone else's sash and went through with his official court duties.

When the imperial prince Nakatsukasa no Miya ${ }^{212}$ was learning Chinese poetry under Jakushin, the latter would pause at regular intervals between the lessons and, shutting his eyes, recite the Buddha's name.

At one time when Jakushin was presented with a horse by Prince Nakatsukasa, he went to court on horseback. En route, he got off his horse whenever he came upon even the smallest stupa, not to speak of large temples, offering prayers for the spiritual advancement of the dead and worshiping the Buddha. Whenever he saw some grass he stopped and let the horse roam about and graze freely.

By this time the sun was already high up in the sky, and the men accompanying him, who had left home in the morning, found that by the time they had arrived at their destination, it was past two o'clock in the afternoon. Jakushin's retainer, who was with the horse, grew so unhappy with the situation that he began to beat the horse cruelly.

Seeing this, Jakushin wept loudly and said, "Among the many animals that exist in this world, it is with this horse that you have come into such close contact. Is this not because a deep bond exists between the two of you from former lives? Perhaps this horse was your father or mother in another life. How tragic that you should commit such a grieveous sin!"

It is because Jakushin had such a heart that in his literary work Chiteiki he wrote, "Although my body is exposed to the sun [that is, works at the court], my heart dwells in the shade [that is, in seclusion]." 213

When Jakushin was older, he shaved his head and went up to Mount Yokawa to study the scriptural writings. At this time, the holy man Soga was still at Yokawa. ${ }^{214}$ Wishing to instruct Jakushin, Soga began to read the opening lines of Makashikan,

212. Prince Tomohira was the seventh son of Emperor Murakami. He was in charge of the Ministry of Central Affairs (Nakatsukasashō) and was therefore referred to as Nakatsukasa no Miya.

213. Chiteiki, 424.

214. The priest Soga (d. 1003) took the tonsure and lived at Enryakuji, where he was a pupil of the famous poet-priest Jien. 
"Ceasing all extraneous thoughts and focusing on meditation on the dharma brings about a clarity and tranquility unheard of in the past." 215

However, Jakushin merely burst into tears and could not stop weeping. Soga clenched his fists, hit Jakushin, and said, "What does somebody who knows so little about all this have to cry about? What a cute little devotee we have here!"

Jakushin simply replied, "I am what I am and you are what you are" and left. After some time had passed, he returned to Soga and promised that things would be different this time. He begged to have the meaning of the religious text transmitted to him. Soga complied with his request, but no sooner had he read the first line of Makashikan, than Jakushin broke down again, as he had done earlier. This time too he was severely reprimanded by his master, and it all ended without his getting past even the first line.

After several days had elapsed he returned again, without any sign of contrition, and after inquiring after his teacher's health, with great trepidation he begged to be instructed. But this time too he began weeping, even more copiously than he had wept before. Seeing this, Soga himself shed tears and, deeply moved, remarked, "Truly, you have a profound understanding of the dharma." He then went on calmly to transmit the sacred teachings to Jakushin.

In this way Jakushin attained unexcelled spiritual merit, and even the imperial regent Fujiwara no Michinaga received instruction from him on the prescriptive teachings.

When Jakushin passed away, Michinaga had the fujomon written on his behalf and distributed 100,000 pieces of cloth made out of basswood. ${ }^{216}$ In the shomon that the priest of Mikawa composed in reply, it is said that he wrote a poem of unexcelled quality. ${ }^{217}$ It goes as follows: "In the past the emperor Yōtei/ offered

215. See Sekiguchi, Makashikan, 20. See also p. 42, n. 54 above.

216. A fujomon was a literary composition requesting various priests to recite the sutras on behalf of a person who had passed away and recording the alms distributed by the patron to ensure the well-being of the deceased in future lives.

217. The shomon was a composition written in reply to the fujömon, accepting the request. The priest of Mikawa was previously known as Oe Sadamoto, the governor of Mikawa. In 986, following Jakushin, he took the tonsure. He went up to Mount Hiei and became a disciple of Genshin. He also undertook a journey to China and lived there for thirty-two years. 
food to one thousand priests./ The Tendai master Chigi [Chih-i]/ appeared as one of the priests, / and so there was one portion too few./ Now the imperial regent has offered 100,000 pieces of cloth/ for the salvation of Jakushin!"218

\section{3:1 The Old Man All the More So of Omi}

Not long ago there was an old man who lived as a beggar in the province of Ōmi. No matter if he were sitting or standing, no matter what he saw or heard, he would merely utter the words "all the more so." Thus it came about that the people of the province started calling him Old Man All the More So. Although he was not specially virtuous, he had spent years wandering about, always being friendly with those he met, and so he came to be well known in the area, and people who saw him would treat him kindly.

At this time, a holy man in the province of Yamato dreamed that this old man would, without a doubt, achieve rebirth in the pure land. Wishing to establish a karmic link with the old man, he went to Ōmi to look for him. He found the old man living in a little grass hut, and he spent the evening asking him about the kind of religious practice that he performed.

However, the old man claimed that there was absolutely nothing he did that constituted a religious observance. The holy man repeated his question but without success, and so in the end he explained, "Actually, I was told in my dream that you would attain rebirth in the pure land. It is for this reason that I have come here specially to see you. Please don't hide anything from me."

To this the old man replied, "There is in fact one practice that I follow. This practice is to say 'all the more so,' repeatedly, no matter what. When I am starving, I think of the sufferings of those who have fallen into the world of the hungry ghosts, and I say to myself, 'All the more so.' So too, when it is too cold or too hot, I think of the heat and cold in hell, and I remind myself how

218. The emperor Yang-ti of the Sui dynasty, who reigned from 604 to 617. In 591 Yang-ti, who was at the time prince Yang Kuang, gave a lavish vegetarian feast for a thousand southern monks. After the banquet, the young prince knelt to receive from Chih-i the "bodhisattva vows" for lay Buddhists and the religious sobriquet of Tsung-ch'ih P'u-sa (Bodhisattva of Absolute Control). Presumably the priest of Mikawa refers to this incident in the shomon. 
much more severe that would be. ${ }^{219}$ Whenever I face any kind of painful situation, it makes me fear all the more the suffering that exists in the lower realms. When I taste something delicious, I meditate on the nectar of the heavens and in this way put an end to all attachment to worldly delights. When I see an unusually beautiful color, when I hear an incomparably melodious voice, even when I smell fragrant incenses, I tell myself that all these add up to nothing. I realize that everything is infinitely more splendrous in the pure land, and this prevents me from being moved by the delights of this world."

The holy man shed tears when he heard what the old man had to say, and, folding his palms in obeisance, he went away. Even if this old man most certainly did not meditate on the magnificence of the pure land, he always kept in mind the fundamental principles of the doctrine, no matter what the situation, and this too amounted to a kind of religious practice leading to the pure land.

\section{5:13 The Poor Man Who Loved Making Architectural Plans}

In recent times there lived an extremely destitute old man. Although he held court rank, he lacked the right connections that would take him to high places. He was a man of old-fashioned tastes, for whom it would have been inconceivable to behave in a manner that was in any way questionable. Because he had some worldly attachments, he was disinclined to take the tonsure. He had no place in which to live, and so he would often take shelter in broken-down buildings.

In this manner he whiled away the months and years. The only activity he engaged in from morning to night was to beg for used paper and writing implements and, having gathered enough, to draw up any number of architectural plans of houses and dream about the places he would build.

"The main hall will be like this. I wonder how the gates should be built"; thus he would make plans and calculations and endlessly engage in his daydreams, which served to console his spirits and to pass the time. Those who saw him or heard about

219. Among the various hells conceptualized in Mahāyāna Buddhism, there is one with eight degrees of cold and eight of heat. It is to this that the old man refers. 
his activities said that his was indeed an example of obsessive behavior.

While it is true that planning for things that can never materialize is a vain exercise, if one thinks about it carefully, seeking solace for the mind ranks high among the pleasures of this world. Many palatial homes stretch over one or two hundred meters, and the world no doubt looks upon such places with the deepest admiration. But in truth, the space we occupy sleeping or waking takes up no more than one room. For the rest, the space is used by others, some with whom we are on intimate terms, others with whom we have no special relationship. Or again it is taken up in building shelters for cows and horses who would normally live in the hills and fields.

Is it not entirely pointless to inflict so much hardship on our bodies and to torment our hearts in this way, worrying about the kind of dwelling we would like to live in?

And yet people imagine they have hundreds and thousands of years in which to live, and so they spend their time choosing building material and polishing the cypress bark [for the roof] and the tiles as if they were jewels and mirrors. What possible use can all this be? The life of the owner is by nature ephemeral, and so he cannot live in his dwelling for long. After his death it will become someone else's home, be knocked over by the winds, or rot away in the rain. Needless to say, if it catches fire, then all the work put into building it over the months and years will be reduced within moments to nothing but smoke.

By contrast, the house that this poor man built in his imagination did not involve running around finding the right location. Nor did he have to work at building or polishing it. His was a house that no wind or rain could destroy. There was no danger from fire either. It took only one piece of paper, and yet it was big enough to shelter his heart.

The bodhisattva Nãgãrjuna said, "Even if a person is rich, the fact that he never stops wanting more makes him poor. If, on the other hand, a poor man does not seek for more, then he is rich." 220

The holy man of Shoshazan Engyojji wrote the following words: "I fold my arms and make them my pillow. In this lies real

220. The source for this quotation is not known. Nāgārjuna, who lived around the year 150, was born into a family of brahmans in south India. He espoused Mahāyāna Buddhism and is well known for his many treatises on the Buddhist sutras. 
prosperity. Why then would I pursue wealth and splendor, which are as ephemeral as the floating clouds?"221

Or again, a certain person recounted the following incident: "In China there was a koto master who always had a koto without strings by his side. He would make sure that it was with him at all times. People found this strange, and when they questioned him about it, his reply was, 'Whenever I look at the koto, various melodies well up within my mind. It has the effect of consoling my spirit and is therefore in no way different from actually playing on the instrument."

Those who build houses are regarded with deep admiration by others, but they are always dissatisfied. In this respect, the house that the poor man built in his mind is in every way more advantageous. His actions were certainly laudable when measured against the worldly activities of men. Still, we must bear in mind that, after all, even the splendors of the heavens have their limitations. The dwelling inside the pot (attractive though it may be) is not what we should be aiming for ultimately. ${ }^{222}$ It goes without saying that instead of wasting our time pursuing vain aspirations, we should yearn for the many-storied buildings and palaces of the western paradise. There we can dwell forever, as long as we truly desire to do so.

221. The holy man Shōkū (910-1007) was a high-ranking Tendai priest. He built Engyōji in Harima. This is probably an adaptation of a similar passage in the Confucian Analects (Lun yu), 7.

222. There is a popular tale about the priest Hichōbō, who entered the pot that an old vendor of medicines was carrying. Inside it he found a splendid palace, and, together with the old man, he enjoyed himself, drinking sake. 


\section{Bibliography}

Abe Akio. "Bōzen to shita kitai." In Bukkyō bungaku kenkyū, vol. 12. Ed. Bukkyō Bungaku Kenkyūkai. Kyoto: Hōzōkan, 1973. et al., eds. Genji monogatari. 6 vols. Nihon koten bungaku zenshū. Tokyo: Shōgakkan, 1972.

, Oka Kazuo, and Yamagishi Tokuei, eds. Genji monogatarijo. Kokugo kokubungaku kenkyūshi taisei, no. 3. Tokyo: Sanseido, 1960.

Alley, Rewi, trans. Bai Juyi, 200 Selected Poems. Beijing: New World Press, 1983.

Andrews, Allan A. The Teachings Essential for Rebirth: A Study of Genshin's "Ōjōyōshū." Tokyo: Sophia University Press, 1973.

Asami Kazuhiko. "Hōjōki no buntai: sakuhin ron e no tegakari to shite." Bungaku 52.5 (1984).

. "Hosshinshū no gentai to zōhō." Chūsei bungaku 22 (November 1977).

Bowring, Richard, trans. Murasaki Shikibu: Her Diary and Poetic Memoirs. Princeton: Princeton University Press, 1982.

Brower, Robert H. "Fujiwara Teika's Maigetsushō." Monumenta Nipponica 40.4 (winter 1985).

. Fujiwara Teika's "Hundred-Poem Sequence of the Shōji Era," 1200: A Complete Translation with Introduction and Commentary. Monumenta Nipponica Monograph 55. Tokyo: Sophia University Press, 1978.

. Fujiwara Teika's "Superior Poems of Our Times": A Thirteenth-Century Poetic Treatise and Sequence. Stanford: Stanford University Press, 1967.

, and Earl Miner. Japanese Court Poetry. Stanford: Stanford University Press, 1961.

, and Steven D. Carter, trans. and eds. Conversations with Shōtetsu (Shötetsu monogatari). Michigan Monograph Series in Japanese Studies, no. 7. Ann Arbor: Center for Japanese Studies, The University of Michigan, 1992.

Brownlee, John. "Jikkinshō: A Miscellany of Ten Maxims." Monumenta Nipponica 29.2 (summer 1974). 
Bukkyō Bungaku Kenkyūkai, ed. Bukkyō bungaku kenkyū, vol. 12. Kyoto: Hōzōkan, 1973.

Cabezon, Jose Ignacio, ed. Buddhism, Sexuality, and Gender. Albany: State

University of New York Press, 1992.

Chao Ts'ung, ed. Ku-wen kuan-chih. Hong Kong: Yu-lien, 1960.

Ch'en, Kenneth. The Chinese Transformation of Buddhism. Princeton: Princeton University Press, 1973.

. Buddhism in China: A Historical Survey. Princeton: Princeton University Press, 1963.

Collcutt, Martin. Five Mountains: The Rinzai Zen Monastic Institution in Medieval Japan. Cambridge, MA: Harvard University Press, 1981.

Eagleton, Terry. Against the Grain: Essays 1975-1985. London: Verso, 1986.

. Literary Theory: An Introduction. Minneapolis: University of Minnesota Press, 1983.

Eco, Umberto. Art and Beauty in the Middle Ages. Trans. Hugh Bredin.

New Haven: Yale University Press, 1986.

. A Theory of Semiotics. Bloomington: Indiana University Press, 1976.

Endō Yoshimoto. "Fūryū kō.” Kokugo kokubun 10.4 (April 1940).

Fujimoto Tokumei. Chūsei bukkyō setsuwa ron. Tokyo: Kasama Shoin, 1977.

Fujioka Tadaharu et al., eds. Izumi Shikibu nikki, Murasaki Shikibu nikki, Sarashina nikki, Sanuki no Suke no nikki. Nihon koten bungaku zenshū, no. 18. Tokyo: Shōgakkan, 1971.

Geddes, Ward. "The Courtly Model: Chōmei and Kiyomori in Jikkinshō." Monumenta Nipponica 42.2 (summer 1987).

Hagitani Boku and Tamiyama Shigeru, eds. Utaawaseshū. Nihon koten bungaku taikei, no. 74. Tokyo: Iwanami Shoten, 1965.

Harada Kōzō. Chūsei setsuwa bungaku no kenkyū. 2 vols. Tokyo: Ōfūsha, 1982.

Hare, Thomas Blenman. "Reading Kamo no Chōmei." Harvard Journal of Asiatic Studies 49.1 (June 1989): 173-228.

Harper, T. J. "A Twelfth-Century Critique of the Tale of Genji." Criticism in Translation 1.1 (September 1976).

Harries, Phillip. "Füryū, a Concept of Elegance in Pre-Modern Literature." In Europe Interprets Japan, ed. Gordon Daniels. Kent: Paul Norbury, 1984.

Hegel, Robert. "Emptiness and Riches in a Tiny Space-The Many Meanings of Höjō." Unpublished paper.

Hisamatsu Sen'ichi, ed. Korai füteishō. In Karonshū, vol. 1. Chūsei no bungaku. Tokyo: Miai Shoten, 1971. , ed. Saigyö shōnin danshö. In Karonshū, vol. 1. Chūsei no bungaku.

Tokyo: Miai Shoten, 1971. and Nishio Minoru, eds. Mumyōshō. In Karonshū. Nihon koten bungaku taikei, no. 65. Tokyo: Iwanami Shoten, 1961. . and Nishio Minoru, eds. Shōtetsu monogatari. In Karonshü. Nihon koten bungaku taikei, no. 65. Tokyo: Iwanami Shoten, 1961.

Horibe Shōji. "Kamo no Chōmei no botsunen ni kansuru ichi shiryō." Kokugo kokubun 11.6 (June 1941). 
Horikawa Zensho. "Kyōgen kigo to Chōmei no bungeikan (suki)." Ikenobō tankiyo 13 (1983).

Huey, Robert N. Kyōgoku Tamekane: Poetry and Politics in Late Kamakura Japan. Stanford: Stanford University Press, 1989.

Hurvitz, Leon, trans. Scripture of the Lotus Blossom of the Fine Dharma (The Lotus Sutra). New York: Columbia University Press, 1976.

Ide, Tsuneo. "Bukkyō bungaku to sō de nai mono." In Bukkyō bungaku kenkyū, vol. 12. Ed. Bukkyō Bungaku Kenkyūkai. Kyoto: Hōzōkan, 1973.

Ienaga Saburō, ed. Nihon bukkyō shi. 3 vols. Kyoto: Hōzōkan, 1967.

Ikeda Kikan. Heian chō no seikatsu to bungaku. Tokyo: Kawade Shobō, 1954.

Imagawa Fumio, ed. Kundoku Meigetsuki. 2 vols. Tokyo: Kade Shobō, 1977.

Imanari, Genshō. "Ren'in Hōjōki no ron." Bungaku 42.2 (1974).

Inagaki Taiichi. "Senjūshō no sekai." In Nihon no setsuwa 3, Chüsei 1, ed. Nagai Giken and Kishi Shōzō. Tokyo: Tōkyō Bijutsu, 1973.

Ishida Mizumaro. "Ōjōyōshū no shisōteki igi." In ōjōyōshū, 1, 5. Nihon shisō taikei. Tokyo: Yūseidō, 1968.

Ishida Yoshisada. Inja no bungaku. Tokyo: Hanawa Shobō, 1968. and Satsukawa Shūji, eds. Minamoto Ienaga nikki zenchūkai. Tokyo: Yūseidō, 1968.

Ishihara Kiyoshi. Shakkyōka no kenkyū. Tokyo: Dōhōsha, 1980.

Iso Mizue. "Biwa hikkyoku denjū sahō no seiritsu to haikei." Tōyō ongaku kenkyū 48 (1982).

. "Hikkyoku zukushi jiken o megutte, sono ni." Kamo no Chōmei no kenkyū 2. Nishō Gakuen Daigaku Kishi Zemihen (June 1976).

Izumi Motohiro, ed. Jikkinshō. Koten bunkō, no. 352. Tokyo: Koten Bunkō, 1976.

Kakimura Shigematsu, ed. Honchō monzui chūshaku. 2 vols. Tokyo: Fūzanbō, 1922. Reprint. Tokyo: Tōyamabō, 1968.

Kamens, Edward. The Buddhist Poetry of the Great Kamo Priestess: Daisaiin Senshi and "Hosshin Wakashü." Michigan Monograph Series in Japanese Studies, no. 5. Ann Arbor: Center for Japanese Studies, The University of Michigan, 1990.

.The Three Jewels : A Study and Translation of Minamoto Tamenori's Sanbōe. Michigan Monograph Series in Japanese Studies, no. 2. Ann Arbor: Center for Japanese Studies, The University of Michigan, 1988.

Karaki Junzō. Chūsei no bungaku. Tokyo: Chikuma Shobō, 1973.

Katagiri, Yōichi, et al., eds. Ise monogatari. In Taketori monogatari, Yamato monogatari, Ise monogatari, Heichū monogatari. Nihon koten bungaku zenshū, no. 8. Tokyo: Shōgakkan, 1972.

Kato, Hilda. "The Mumyōshō of Kamo no Chömei and Its Significance in Japanese Literature." Monumenta Nipponica 23.3/4 (summer/autumn 1968).

Kato, Shuichi. A History of Japanese Literature: The First Thousand Years. New York: Kodansha International, 1979.

Keene, Donald, ed. and trans. "An Account of My Hut." In An Anthology of Japanese Literature. Penguin Classics. Bungay, Suffolk: Chaucer Press Ltd., reprint 1968. 
, ed. An Anthology of Japanese Literature. Penguin Classics. Bungay,

Suffolk: Chaucer Press Ltd., reprint 1968.

Kelsey, Michael. Konjaku Monogatari-shū. Boston: Twayne, 1982.

Kidō Saizō and Imoto Nōichi, eds. Tsukuba mondō. In Rengaronshū,

Haironshü. Nihon koten bungaku taikei, no. 66. Tokyo: Iwanami

Shoten, 1961.

Kinoshita Masao. Heian jōryū bungaku no kotoba. Tokyo: Nihon Bunpō Shinchō, 1968.

Kishi, Shōzō. "Hosshinshū kara Hōjōki e." Kokugo to kokubungaku 55.3

(March 1978): 1-13.

. "Hōjōki fushō no kai." In Kokugakuin zasshi 838 (February 1977).

"Hijiri to setsuwa bungaku: Hosshinshū no sekai." In Nihon no setsuwa 3, Chūsei 1, ed. Nagai Giken and Kishi Shōzō. Tokyo: Tokyō Bijutsu, 1973.

Kobayashi Tomoaki, ed. Uji shüi monogatari. Nihon koten bungaku zenshū, no. 28. Tokyo: Shögakkan, 1973.

Koizumi Hiroshi and Takahashi Nobuyuki, eds. Sanbōeshūsei. Tokyo: Kasama Shoin, 1980.

Konishi, Jin'ichi. A History of Japanese Literature. 3 vols. Princeton: Princeton University Press, 1991.

.Nihon bungeishi, vol. 2. Tokyo: Kabushiki Kaisha, Kōdansha, 1986. . "Michi and Medieval Writing." In Principles of Classical Japanese

Literature, ed. Earl Miner. Princeton: Princeton University Press, 1985.

. "Iwayuru chūko kara iwayuru chūsei e." Musashino bungaku 26 (1980).

. Michi: Chūsei no rinen. Nihon no koten, no. 3. Tokyo: Kōdansha, 1975.

. Image and Ambiguity: The Impact of Zen Buddhism on Japanese Literature. Trans. James Araki. Tokyo: Program for Comparative Study on Japanese and Chinese Literatures, Tokyo University of Education, 1973.

. "Fūryū: An Ideal of Japanese Esthetic Life." Orient/West 7.7 (July 1962).

. "Michi no keisei to kairitsuteki sekai." Kokugakuin zasshi 57.5 (September 1956).

"Shunzei no yūgenfū to shikan." Bungaku 20.2 (February 1952).

Kristeva, Julia. Desire in Language: A Semiotic Approach to Literature and Art. Trans. Thomas Gora, Alice Jardine, and Leon S. Roudiez. Oxford: Basil Blackwell, 1980.

Kubota Jun. Saigyō Chōmei Kenkō: Sōan bungaku no keifu. Tokyo: Meiji Shoten, 1979.

. Chūsei bungaku no sekai. Tokyo: Tōkyo Daigaku Shuppankai, 1972. and Yamamoto Akio, eds. Myōe shōninshü. Tokyo: Iwanami Shoten, 1981.

Kuwabara Hiroshi, ed. Mumyōzōshi. Shinchō Nihon koten shūsei. Tokyo: Shinchōsha, 1976.

LaFleur, William R. The Karma of Words: Buddhism and the Literary Arts in Medieval Japan. Berkeley: University of California Press, 1983. . Mirror for the Moon: A Selection of Poems by Saigyō (1118-1190).

New York: New Directions, 1978. 
. "Saigyō and the Buddhist Value of Nature." History of Religions 13.2

(November 1973): 93-128; 13.3 (February 1974): 227-48.

Levy, Dore J., trans. Chinese Narrative Poetry: The Late Han through T'ang

Dynasties. Durham: Duke University Press, 1988.

Liu, James J. Y. Language-Paradox-Poetics: A Chinese Perspective.

Princeton: Princeton University Press, 1988.

. Chinese Theories of Literature. Chicago: University of Chicago Press, 1975.

. The Art of Chinese Poetry. Chicago: University of Chicago Press, 1962.

Luk, Charles, trans. and ed. The Vimalakîrti Nirdesa Sutra. Berkeley: Shambala, 1972.

McCullough, Helen Craig, trans. Tales of Ise: Lyrical Episodes from TenthCentury Japan. Tokyo: University of Tokyo Press, 1968.

McCullough, William H., and Helen Craig McCullough. A Tale of Flowering Fortunes: Annals of Japanese Aristocratic Life in the Heian Period. 2 vols. Stanford: Stanford University Press, 1980.

Manaka Fujiko. Kokubungaku ni sesshū sareta bukkyō. Tokyo: Bun'ichi Shuppan, 1972.

Marra, Michele. The Aesthetics of Discontent: Politics and Reclusion in Medieval Japanese Literature. Honolulu: University of Hawaii Press, 1991.

. "The Development of Mappō Thought in Japan." Japanese Journal of Religious Studies 15.1 (March 1988); 15.4 (December 1988).

"Semi-Recluses (Tonseisha) and Impermanence (Mujō): Kamo no Chōmei and Urabe Kenkō." Japanese Journal of Religious Studies 11.4 (December 1984).

, trans. "Mumyōzōshi: Introduction and Translation." Monumenta Nipponica 39.2 (summer 1984); 39.3 (autumn 1984); and 39.4 (winter 1984).

Mass, Jeffrey P. Warrior Government in Early Medieval Japan. New Haven: Yale University Press, 1974.

Matilal, Bimal K. "A Critique of the Madhyamika Position." In The Problem of Two Truths in Buddhism and Vedanta. Dordrecht, Holland: D. Reidel, 1973.

Matsumura Seichi, et al., eds. Kagerō nikki. In Tosa nikki, Kagerō nikki. Nihon koten bungaku zenshū, no. 9. Tokyo: Shōgakkan, 1973.

Matsuo Satoshi and Nagai Kazuko, eds. Makura no sōshi. Nihon koten bungaku zenshū, no. 11. Tokyo: Shōgakkan, 1974.

Matsushita Daizaburō. Zokukokkataikan. Tokyo: Kadokawa Shoten, 1958. and Watanabe Fumio. Kokkataikan. 2 vols. Tokyo: Kyōbunsha, 1958.

Mezaki, Tokue. "Aesthete-Recluses during the Transition from Ancient to Medieval Japan." In Principles of Classical Japanese Literature, ed. Earl Miner. Princeton: Princeton University Press, 1985.

Miki Sumito. Kankyo no hito: Kamo no Chōmei. Nihon no sakka, no. 17. Tokyo: Shitensha, 1984.

, ed. Hōjōki, Hosshinshū. Shinchō Nihon koten shūsei. Tokyo: Shinchōsha, 1976.

. “Hōjōki no mappi." In Kōza Nihon bungaku no sōten, Chūsei, vol. 3.

Tokyo: Meiji Shoin, 1969. 
Miller, Roy Andrew. The Japanese Language. Chicago: University of Chicago Press, 1967.

Miner, Earl. An Introduction to Japanese Court Poetry. Stanford: Stanford University Press, 1968.

Minobe Shigekatsu, ed. Kankyo no tomo. In Chūsei no bungaku. Tokyo: Miai Shoten, 1982.

Moore, Jean. "Senjushü: Buddhist Tales of Renunciation." Monumenta Nipponica 41.2 (summer 1986).

Morrell, Robert E. Sand and Pebbles (Shasekishü): The Tales of Mujū Ichien, A Voice for Pluralism in Kamakura Buddhism. Albany: State University of New York Press, 1985.

. "Kamakura Accounts of Myōe Shōnin as Popular Religious Hero." Japanese Journal of Religious Studies 9.2-3 (June-September 1982). - "Mujū Ichien's Shinto-Buddhist Syncretism: Shasekishū Book 1." Monumenta Nipponica 28.4 (winter 1973).

. "The Buddhist Poetry in the Goshūishū." Monumenta Nipponica 28.1 (spring 1973).

Morris, Ivan. As I Crossed a Bridge of Dreams: Recollections of a Woman in Eleventh-Century Japan. New York: Dial, 1971.

. The World of the Shining Prince: Court Life in Ancient Japan. New York: Knopf, 1969.

Morris, Mark. "Waka and Form, Waka and History." Harvard Journal of Asiatic Studies 46 (1986).

. "Buson and Shiki." Parts 1 and 2. Harvard Journal of Asiatic Studies 44/45 (1984/1985).

Nagai Giken. Nihon bukkyō bungaku kenkyū. Tokyo: Toyoshima Shobō, 1967.

. "Kyōgen kigo ni tsuite." Nihon bukkyō gakka nenpō 29 lOctober 1963).

Nagano Jōichi. Setsuwa bungaku ronkō. Tokyo: Kasama Shoin, 1980.

Nagazumi Yasuaki and Shimada Isao, eds. Kokon chomonju. Nihon koten bungaku taikei, no. 84. Tokyo: Iwanami Shoten, 1966.

Nakamura Shinichirō. Irogonomi no kōzō. Tokyo: Iwanami Shoten, 1985.

Nishimura Töru. Ōchō renshi no kenkyū. Tokyo: Keiō Gijuku Daigaku Gengo Bungaku Kenkyūjō, 1972.

Nishio Kōichi, ed. Senjūshō. Koten bunkō, no. 370. Tokyo: Koten Bunkō, 1977.

Nose Asaji. "Chūsei bungaku bi." In Nose Asaji chosaku shū 1. Tokyo: Shinbunkaku Shuppan, 1942. Reprint, 1985.

Ōhashi Shunnō, ed. Ippen shōnin gokuraku. In Hōnen, Ippen. Nihon shisō taikei, no. 10. Tokyo: Iwanami Shoten, 1971.

Okamoto Keidō. "Genji monogatari no suki: Kashiwagi no maki ni miru suki." Ube kokubun kenkyū 12 (March 1987).

Ōno Susumu. "Ōchō bungaku no kotoba." In Nihon bungaku kenkyū, vol.

2. Tokyo: Shinchösha, 1976.

Ōso Neshōsuke and Horiuchi Hideaki, eds. Wakan rōeishū. Shinchō Nihon koten shūsei. Tokyo: Shinchōsha, 1983.

Ozawa Masao. Fukurozōshi chūshaku. 2 vols. Tokyo: Hanawa Shobō, 1973. , ed. Kokin wakashũ. Nihon koten bungaku zenshū, no. 7. Tokyo: Shōgakkan, 1971. 
Pandey, Rajyashree. "Women, Sexuality, and Enlightenment: Kankyo no tomo." Monumenta Nipponica 50.3 (autumn 1995).

"Love, Poetry, and Renunciation: Changing Configurations of the Ideal of Suki." Journal of the Royal Asiatic Society 5.2 (July 1995).

. "Suki and Religious Awakening: Kamo no Chōmei's Hosshinshū." Monumenta Nipponica 47.3 (autumn 1992).

Paul, Diana Y. Women in Buddhism: Images of the Feminine in the Mahāyāna Tradition. 2nd ed. Berkeley: University of California Press, 1985.

Pe, Maung Tin, trans. The Path of Purity: Buddhaghosa's Visuddhimagga. London: Luzac, 1971.

Plutschow, Herbert. “Is Poetry a Sin? Honji-suijaku versus Poetry." Oriens Extremus 25.2 (1978).

Rewi, Alley, trans. Bai Juyi, 200 Selected Poems. Beijing: New World Press, 1983.

Riffaterre, Michael. Semiotics of Poetry. Bloomington: Indiana University Press, 1978.

Rodd, Laurel Rasplica, and Mary Catherine Henkenius. Kokinshū: A Collection of Poems Ancient and Modern. Princeton: Princeton University Press, 1984.

Royston, Clifton W. "Utaawase Judgments as Poetry Criticism." Journal of Asian Studies 34.1 (November 1974).

."The Poetics and Poetry Criticism of Fujiwara Shunzei (1114-1204)." Ph.D dissertation, University of Michigan, 1974.

Sadler, A. L., trans. "The Ten Foot Square Hut" and "Tales of the Heike." Rutland, VT: Charles Tuttle, 1972.

Sakurai Yoshiaki. "Inton to geinō: sono ichimen." Kokugo to kokubungaku 50 (April 1973).

Sansom, George. A History of Japan to 1334. Vol. 1 of A History of Japan. Stanford: Stanford University Press, 1958.

. Japan: A Short Cultural History. New York: D. Appleton Century, 1943.

Seidensticker, Edward G., trans. The Tale of Genji. New York: Knopf, 1976. , trans. The Gossamer Years: The Diary of a Noblewoman of Heian Japan. Rutland, VT: Charles Tuttle, 1964.

Sekiguchi Shindai, ed. Makashikan. Tokyo: Iwanami Shoten, 1966.

Shigemi Kazuyuki. "Gakköshiki o megutte: Chömei Hosshinshū kentō." Bukkyō bungaku 1 (March 1977).

Shimura Kunihiro. Chūsei setsuwa bungaku kenkyū josetsu. Tokyo: Ōfusha, 1974.

Shinoda, Minoru. The Founding of the Kamakura Shogunate. New York: Columbia University Press, 1960.

Stinchecum, Amanda. "Narrative Voice in the Tale of Genji." lllinois Papers in Asian Studies, no. 5. Champaign-Urbana, IL: Center for East Asian and Pacific Studies, University of Illinois, 1985.

Takagi Ichinosuke, et al., eds. Heike monogatari. 2 vols. Nihon koten bungaku taikei, nos. 32 and 33. Tokyo: Iwanami Shoten, 1962.

Takakusu, Junjirō. The Essentials of Buddhist Philosophy. Honolulu: University of Hawaii, 1947.

Tanabe, George J. Myōe the Dreamkeeper: Fantasy and Knowledge in Early Kamakura Buddhism. Cambridge: Harvard University Press, 1992. 
Tsuji Katsumi. "Kamo no Chōmei Ise gekō nenjikō." Koten ronsō 11 (December 1982).

Tsukudo Reikan. Tsukudo Reikan chōsakushū. Vol. 1. Tokyo: Serika Shobō, 1976.

Unno Yasuo, ed. Ima kagami zenshaku. 2 vols. Tokyo: Fukutake Shiten, 1983.

Ury, Marian. "Recluses and Eccentric Monks: Tales from the Hosshinshu by Kamo no Chōmei." Monumenta Nipponica 27.2 (summer 1972).

Uryū Toshikatsu. "Hōjōki no fushō no amida butsu kō." Kaishaku 9.3 (March 1963).

Wada Hidematsu, ed. Bunkidan. Matsuura hakushaku bunkō. Tokyo: Gakusaidō Tosho, 1918

Waley, Arthur. The Life and Times of Po Chü-i, 772-846. London: Allen and Unwin, 1949.

Chinese Poems. London: Allen and Unwin, 1946.

, trans. The Tale of Genji, Tokyo: Charles Tuttle, 1970.

, trans. The Book of Songs. London: Allen and Unwin, 1937. Reprint, 1969.

Washio Junkei, ed. Togano o Myōe shōnin denki. In Tōhō bukkyō sōsho, vol. 5. Tokyo: Tōhō Bukkyō Sōsho Kankōkai, 1925.

Watanabe Tamotsu, ed. Saigyō sankashū zenchūkai. Tokyo: Kasama Shobō, 1971.

Watanabe Tsunaya, ed. Shasekishū. Nihon koten bungaku taikei, no. 85). Tokyo: Iwanami Shoten, 1966.

Watson, Burton. Four Huts: Asian Writings on the Simple Life. Boston: Shambala, 1994.

, trans. and ed. The Columbia Book of Chinese Poetry: From Early Times to the Thirteenth Century. New York: Columbia University Press, 1984.

, trans. "Record of the Pond Pavilion." In Japanese Literature in Chinese, vol.1. New York: Columbia University Press, 1975.

, trans. The Complete Works of Chuang-Tzu. New York: Columbia University Press, 1968.

Williams, Raymond. Keywords: A Vocabulary of Culture and Society. Glasgow: Fontana Press, 1976.

Yamada Ryūjō. "Mappō shisō ni tsuite." Indogaku bukkyōgaku kenkyū 4.2 (March 1956).

Yamada Shōzen. "Saigyō hokkekyō nijūhapponka hyōshaku."Taisho daigaku kenkyū kiyo 7 (1985).

. "Saigyō sōan seikatsu: Takano yama o chūshin ni." Kokubungaku tōsa 13 (November 1984).

. "Fushō AmidaButsu zairon: Hōjōki kesshōbun no kaishaku." Taishō daigaku kenkyū kiyō 65 (March 1980): 127-49.

. "Gatsurinkan to chūsei waka." Bukkyō to girei, Katō Shuichi sensei koki kinen ronbunshū. Bukkyō Minzoku Gakkai, Kokushō Kankōkai, 1977.

. "Kamo no Chōmei bannen no shisō to shinkō." Taishō daigakuin kenkyū ronshü 23 (March 1977).

. "Futari no Chōmei: Hōjōki kara Hosshinshü e." Kokubungaku tōsa

2 (March 1973): 56-64. 
. "Myōe no waka to bukkyõ." Kokugo to kokubungaku 1 (April 1973). "Chūsei goki ni okeru waka soku darani no jissen." Indogaku bukkyōgaku kenkyū 16.1 (December 1967).

. "Waka renga ni okeru hōraku ni tsuite." Indogaku bukkyōgaku kenkyū 15.1 (December 1966).

. "Chūsei setsuwa ni mieru bungeikan: Shasekishū no baai." Buzan gakuhō 7 (March 1961).

. "Chūsei setsuwa ni mieru bungeikan: Jikkinshō no baai." Buzan gakuhō 6 (March 1960).

. "Kyōgen kigo no ni sokumen: Yoshishige Yasutane no shi kan no hensen to Tendai kyōgaku to no renkan." Buzan gakuhō 5 (March 1959).

. "Kyōgen kigo seiritsu kō." Kokubungaku tōsa 14 (February 1956).

Yamaguchi Makoto. "Hosshinshū jobun kō." Kochidai kokubun 13 (December 1982).

Yamamoto Ritatsu, ed., Murasaki Shikibu nikki. In Murasaki Shikibu nikki, Murasaki Shikibu shū. Shinchō Nihon koten shūsei, 35. Tokyo: Shinchōsha, 1980.

Yanase Kazuo. Mumyōshō zenkō. Tokyo: Katō Chūdōkan, 1980. . Hōjōki kaishaku taisei. Tokyo: Taishükan, 1972.

. Kamo no Chōmei no shinkenkyū. Tokyo: Kasama Shobō, 1962. ed. Kamo no Chōmei zenshū. Tokyo: Kasama Shobō, 1971.

Yasuraoka Kōsaku, ed. Hōjōki. Kōdansha gakujutsu bunko, no. 459. Tokyo: Kōdansha, 1980.

Yokoyama Kazumi. "Kamo no Chōmei ni okeru suki ishiki no tenkai: Ima Kagami o setten to shite." Nishōgakusha daigaku jinbun ronsō 17 (March 1980).

Yoshizawa Yoshinori. Gengoshakusen. Tokyo: Seiwa Shōin, 1950.

Yuasa, Yasuo. The Body: Toward an Eastern Mind-Body Theory. Albany: State University of New York Press, 1987. 


\section{Index}

aesthete recluse, 49-51. See also suki no tonseisha

Akimoto, 120-21

akkō (slander), 11

Amida Buddha, 147, 155, 157, 159 , $161,167-69$

Ānanda, 43

Ankyoin Chōken, 27

Ariwara no Narihira, 84

Atsuyori. See Dōin

Avatamsaka Sutra, 11, 16

bonnō soku bodai, 31,38

Brower, Robert, 98

Buddhaghosa, 116

Buddhism, 1-7, 21, 26, 29-31, 34, 65, 111,119 ; Hossō doctrine of, 51 ; Jōdo sect of, 21 ; and language, 912: Mahāyāna teachings of, 31-32; and nature, 161-65; and Po Chü-i, 16-17, 21, 145-46; problem of attachment in, 134-35, 137; and suki, 112-14, 123-34; Tendai doctrine of, 18-20, 32, 37-39, 44, 47-48; and waka, 35-37, 42-52, 131-34, 141, 149; and "worldly writing," 9-12, 21; Zen, 10. See also nonduality, Lotus Sutra, hōben, Vimalakïti Sutra, and mujō bukkyo bungaku, 4 bukkyō gakusha, 5

Bunkidan, 60-62, 73, 159-60

Bureau of Poetry (wakadokoro), 57$58,75-76,78,80$

Byōdo (Priest), 120 chi. See $k i$

Chiteiki, 7, 20, 140, 146-56, 161

Chuang Tzu, 10-11

Confucianism, 13-17, 19-20, 22-23, $145-46,149-54$

dai (topic), 79, 98-99

Daini no Sukemichi, 133-34, 159

dharani (mystical verses), 46-47, 129

Dōin (Atsuyori), 105, 107, 109

duality. See nonduality

Eien, 51, 107-9

Eigu Utaawase, 76

Eishū, 125-27, 131-34, 136

enlightenment, $7,113,115,118,124$, $133,140,160,165-67$

En'yu (Emperor), 18

evanescence. See mujō

expedient means. See hōben

fang chang. See hojō

fangyen. See högen

feeling. See nasake

feng liu. See füryū

fu, 137-38

Fuboku wakashō, 63-64, 72-73

Fujiwara no Akisue, 40

Fujiwara no Ariie, 75-77

Fujiwara no Kintō, 21, 103

Fujiwara no Kiyosuke, 94, 105

Fujiwara no Masatsune, 75, 77, 80

Fujiwara no Motokane, 61

Fujiwara no Mototoshi, 39-40, 94, 108 
Fujiwara no Nagachika. See Zenjaku Fujiwara no Nagakiyo, 64

Fujiwara no Nagatō, 103

Fujiwara no Sanetoshi, 61

Fujiwara no Shigeie, 40

Fujiwara no Shunzei, 40, 42-45, 49, $53-54,67,74-78,82,95-96,104-$ 5,130

Fujiwara no Suetsune, 40

Fujiwara no Tadachika, 62-63

Fujiwara no Tadamichi, 60,160

Fujiwara no Teika, 5, 42, 74-75, 77$78,80,98,104$

fujōkan, 116

Fukurozōshi, 93-94, 102n.140, 103, 105

funi. See nonduality

füryū, 34-35, 41, 83

fushō. See fushō no amida butsu

fushō no amida butsu, 166-67, 170

Gakkōshiki, 80, 81n.112

Gen Tötoku. See Minamoto no Tsunenobu

Genji ippon kyō, 27

Genji monogatari, 4n.4, 22-27, 96, 117-18

Genpin, 120

Genshin, 21, 134-35, 158

Go-Ichijō, 120

gokurakue, 20

Goshūi wakashū, 35

Goshüishū. See Goshüi wakashū

Go-Toba, 60, 74-75, 77-78, 98

Go-Toba-in shōji saido hyakushu, 74

Go-Toba-in shojji shodo hyakushu, 74

gunki monogatari (historical war tales), 26-27

gyō (religious practice), 131-32; and sanji no, 131; and mashite no, 13132

Gyōgi, 163, 171-72

Gyozai, 50

Han Wen Ti, 148-49

hao se. See irogonomi

Hare, Thomas, 2, 107-8, 108n.147. 109 n. 150

Heike monogatari, 26-27

hikkyoku zukushi, 60, 160

hinabi. See miyabi

hijiri, 112-13,120,126, 132

höben, $6,10,23-24,27,54,82,166$. 168; in Genji monogatari, 23-24; in Lotus Sutra, 31-32, 52; and nonduality, 52; in Vimalakïrti

Sutra, 136-37, 141-42

höjo (ten-foot-square hut), 60, 65-66, $139-41,143-45,147,154-56,165$

Hōjōki, 2, 7-8, 56, 65, 68, 70, 78-80. 139-41; and Chiteiki, 147-56, 161; concluding section of, 165-72;

fushō no amida butsu in, 167-68; and hōjō, 143-45, 165; Chōmei's life in, 156-65; mujo in, 151-52, 154; and Po Chü-i, 163-64; and Po Chü-i's Lu shan ts'ao-t'ang chi, 145-47

hon'i (essence), 98

Honichi, 131, 133, 136, 158

honji suijaku, 46, 48, 54, 72, 82

hosshin. See religious awakening Hosshin wakashū, 35-36

Hosshinshū, 2, 7-8, 29, 56, 112, 16871; defense of suki in, 133; love stories in, 115-18; music and poetry as religious practices in. 131-34; preface to, 112-13; problem of attachment in, 134-35, 137; refinement and spiritual purity in, 118-23; Saigyō in, 11920; suki and hosshin in, 123-31; sukibito in, 120-22; sukimono in. $111,113-14,124-27,129,131$, 138; and Yoshishige Yasutane, 147 hotoke no michi (way of the Buddha), 36,39

Hyōhanki, 63

Ima kagami, 27, 124, 128

Imanari Genshō, 142-43, 168-70

impermanence. See mujō

inakabi. See miyabi

intonsha. See tonseisha

Ippen Shönin, 31

irogonomi, 83-84, 118; in Genji monogatari, 88-89; in Ise monogatari, 84-85; in Kokinshū, 84n.114; and michi, 92-93; in Mumyōshō, 92; in Mumyōzōshi, 9293; and suki, 83-85

Ise monogatari, 84-85, 89, 95

Iseki, 72

iyu (fancy phrases), 11

Japanese poetry. See waka Jien, 5, 48, 74-75

Jikkinshō, 29-30, 59, 61, 73, 79

Jōmyō. See Vimalakỉrti

Jōtōmon-in, 121 
jūaku (ten evils), 11

jukkai (personal grievances), 65

Kagerō nikki, 22

Kakunō, 132-34

Kamens, Edward, 18n.24, 36

Kamo no Arisue, 63

Kamo no Chōmei, 2-3, 5-7, 54-57; activities in Bureau of Poetry, 7678; in Bunkidan, 59-62; early years, 62-66; in Jikkinsho, 59, 61; journey to Ise, 71-72; journey to Kamakura, 80; last years, 80-81; life as sukimono, 156-65; marriage status, 67-68, 70; in Minamoto Ienaga nikki, 57-59; move to secluded life, 78-80, 154; participation in poetry contests, 66,71 , 73-74, 76-78; poems in Kamo no Chõmei shū, 63-65; pursuit of music, 73. See also Höjöki,

Hosshinshū, and Mumyōshō

Kamo no Chōmei shū, 2, 56, 63-65, 68

Kamo no Mabuchi, 4

Kamo no Nagaakira. See Kamo no Chōmei

Kamo no Nagahira, 63

Kamo no Nagamori, 62-63

Kamo no Nagatsugu, 62-63, 66

Kamo no Shigeyasu, 69

Kamo no Sukekane, 58

Kamo no Sukemitsu, 64

Kamo no Sukesue, 63

Kangakue, 18-21

kangen no michi (way of music), 73

Kankyo no tomo, 144-45

Karin'en (Grove of Poetry), 69-70

Kāśyapa, 10, 43

katsura (cassia trees), 156, 158-59

kawazu, 101-2

Kenshō, 71, 73

$k i, 145$

Ki no Tsurayuki, 22, 24, 39

kigo, 20, 134. See also kyōgen kigo

Kikuawase (Chrysanthemum Contest), 66

Kishi Shōzō, 169-70

Kojiki, 13, 23, 46

kojitsu, 95, 97-99

Kokin wakashū. See Kokinshū

Kokinshü, 24, 34-35, 39, 43, 75,

84n.114, 92, 94-95, 100-101;

preface to, 24

Kokon chomonjū, 109

koku bungakusha, 5 kokugaku, 169

kokugakusha, 166

Konishi Jin'ichi, 34, 44, 108

Konjaku monogatari shu, 28-29

Konoe (Emperor), 63

Korai futeishō, 42-43, 95

koshiki, 80

koshoku, 83, 84n.114

Kristeva, Julia, 139

k'uangyen iyu. See kyōgen kigo

kugutsu, 107

Kumagai Naozane, 26-27

Kunaikyō (Lady), 102-3

Kunisuke, 115-16, 122-23

kyōgen kigo (wild words and fancy phrases), $6,9,13,15,17-21,26$, $30,33-34,37,43,45,52,54,82$

kyōgen kigyo. See kyōgen kigo

Kyōkai, 28

LaFleur, William, 3n.3, 44, 52, 164 n.201

Lao Tzu, 11

Lotus Sutra, 5, 11-12, 18-21, 25, 36, $43,72,117-18,148,150,155$; hōben in, 31-32, 52; poems on, 18 , 44-45

Lu shan ts'ao-t'ang chi, 145

Makashikan, 42-44

Makura no sōshi, 90

Mañjuśrī, 142-43

Mansei. See Manzei

mantra. See Shingon

Man'yōshū, 94-95, 100

Manzei, 135, 156, 158

mappō, 32-33, 72n.98

mashite, 131-32

masuo no susuki, 100-101, 106

Meigetsuki, 75, 77

"Melody of the Flowing Stream." See ryusen

Mezaki Tokue, 49, 164

michi, 41-42, 48, 60, 92-93, 110, 127; waka as, 34, 39-42, 53, 94, 102, 104-6; and Tendai Buddhism, 3740

Minamoto no Ienaga, 6, 57-59, 61-62, $75-76,79,139$

Minamoto no lenaga nikki, 6, 57-59, 61-62, 139

Minamoto no Michichika, 75-76

Minamoto no Mitsuyuki, 73

Minamoto no Sanetomo, 80

Minamoto no Shunrai, 39, 94 
Minamoto no Tamenori, 17-19

Minamoto no Toshiyori. See Minamoto no Shunrai

Minamoto no Tsunenobu, 156, 159

Minamoto no Yoritomo, 41

Miner, Earl, 98

miyabi, 35

mōgo, 11, 20

Mo-ho chih-kuan. See Makashikan

Motoori Norinaga, 4

mudra, 47

mujō, 26, 35, 44, 113, 136, 142-43, $150-52,154,157-58,160$

Mujū Ichien, 29, 33-34, 82; defense of waka, 36, 45-48, 135

Mumyōshō, 2, 6-8, 56-57, 96, 105, 107-8, 110-11; and Chōmei's mentor, Shōmyō, 66-67, 73; and Chōmei's poetry teacher, Shun'e, 69-70, 73, 97-97, 104, 108; and Chōmei's pursuit of music, 73 , 105-6; and Chōmei's success as a poet, 70-71, 76-77: hon' $i$ in, 9899; ideal sukimono in, 99, 100104, 106, 110-12; irogonomi and, 92; kojitsu in, 97-98; and suki, 82, 97, 99, 101-2, 110

Mumyōzōshi, 92-93

munashiki kotoba (false words), 30

Murasaki Shikibu, 23-25, 27, 86, 90

Murasaki Shikibu nikki, 90-91

Myōe (Priest), 48-49

Myōe shōnin ikun, 48

Nāgārjuna, 31

Nakahara Ariyasu, 71, 73, 105, 159

Nansenzai, 67

Narimichi, 123-24, 126, 129, 131

nasake (sensitivity, feeling), 65, 101 , $118-19,122-23,130$

nenbutsu, 18, 50, 59, 133, 136-37, $150,156,166-67,170$

Nihon genpō zen'aku ryōiki. See Nihon ryōiki

Nihon ryōiki, 28

Nihon shoki, 13, 22

Nijō (Emperor), 63

Nijō Yoshimoto, 110-11

Nijühapponka, 18, 45

Nöin, 96, 102n.140, 109

Noin utamakura, 96

nonduality (funi), 30-33, 44, 52-54, $123,142-43,168-69,171$

ōjōyōshu, 155-56
Po Chü-i, 9-10, 14-18, 21, 26, 82, $121,139-40,144,148-49,155$, 158-59, 163-64; and k'uangyen iyu (kyōgen kigo), 14-18; and $L u$ shan ts'ao-tang chi, 145 poetry contests. See utaawase pure land, 117, 133, 137, 155, 16162,169

refinement. See $y \bar{u}$ religious awakening (hosshin), 36 , $112,115,123,134,138$

renga, $77,108,110-11$

Rennyō (Priest), 128-31, 136

renunciation, 1, 3, 6-7, 12, 61

Ryōjin hishō, 95

ryōzetsu (equivocation), 11

ryūsen, 156, 159-60

Saichō, 38-39

Saigyō, 29-30, 47-48, 50-51, 53, 61 , $94,96,119-20,162,164$, 171-72

Saiygō shōnin danshō, 94

Śakyamuni, 10,43

Samantabhadra Bodhisattva Sutra, 43

Sanbōekotoba, 17

Sanesada, 97, 100

Sankaiki, 62-63

Sankashū, 162

sanmitsu (three mysteries), 46

santai (three styles of poetry), 77

Sarashina nikki, 25-26, 53

Sasamegoto, 104, 130

semi no ogawa, 71,73, 106-7

Senjüshō, 29, 50-51, 144

Senshi (Senshi Naishinnō), 35-36

senshübanzei, 122

sensitivity. See nasake

Senzaishu, 67, 70, 74, 79, 105-7

setsuwa, 26-30, 33-34, 95, 102, 112 , 124, 144; love stories in, 115-18; and Shasekishū, 33-34. See also Hosshinshū

Shakkyōka, 35-36

Shasekishū, 29, 33-34, 45-48, 135

Shih-ching, 14

shikan (concentration and insight), 42,44

Shinchoku senshü, 67

Shingon, 46-47, 116, 122

Shinkei, 104

Shinkokin wakashu. See Shinkokinshü

Shinkokinshu, 57-67, 71, 77, 106-7; compilation of, $75-76,78-79$ 
Shinto, 4, 46-48, 54

shōbō jissō (ultimate reality), 30,33

shōji soku nehan (samsara is nirvana),

$6,31,38$

Shōmyō, 66-67, 69, 73

Shōtetsu, 53

Shōtetsu monogatari, 53-54

Shūi wakashū, 35, 43, 162

Shūishü. See Shūi wakashū

shukke, 49

Shun'e, 67-70, 73, 97, 100, 104, 159

Shushi Naishinnō. See Takamatsu-ín

"Song of Everlasting Sorrow," 15

"Song of the Lute," 158-59

soragoto (lies), 23

Sukekuni, 134

suki, 6-7, 48-49, 54-55, 59, 82-83,

$85,97,111,118$; and artistic refinement, 89-91; in Fukurozōshi, 93; in Genji monogatari, 85-90; and hosshin, 123-24, 128, 138; in Hosshinshu, 113-14, 122, 126-28, 131,136 ; and irogonomi, 83, 9193; in Kamakura period, 92-93, 129; in Makura no sōshi, 90; and michi, 39, 92-95; in Mumyöshō, 97, 99, 108, 111 ; in Murasaki Shikibu nikki, 90-91; and waka, 92-95, 99

suki no tonseisha, 49, 164

sukibito, in Hosshinshū, 120-23; in Mumyōshō, 107-8

sukigokoro, 85,87

sukihijiri, 128,130

sukimono, $62,73,85,93,97,114$, 136; in Genji monogatari, 87-88; in Hosshinshü, 111-14, 124-27, 129, 131, 138; in Mumyōshō, 99, 101-2, 104, 106, 110-12; in Murasaki Shikibu nikki, 90-91

sukiwaza, 85,87

sukizukishi, 85

Sütoku (cloistered emperor), 130

Taira no Nobunori, 63

Takamatsu-in, 63, 66

takuboku, 60, 160

Tao Tsung, 16

Taoism, 11, 20, 34, 145, 149

Teishi (Empress), 128

ten-foot-square hut. See hōjō

Togano o Myōe shōnin denki, 47-48

Tokimitsu, 127-28, 131, 134, 136

Tōnobō. See Kunisuke

tonsel, 49

tonseisha (religious recluses), 49, 55: suki no tonseisha, 49, 164

Tōren (Priest), 100-101, 106

Tosa nikki, 22

Toshiyori, 101, 107-9

ts'ao tang (grass-thatched hall), 145

Tsukimōdeshū, 69

Tsukuba mondō, 110

Tu Fu, 14, 145

Uji shūi monogatari, 28-29, 102n.140

Unzushō, 95

upaya. See hōben

utaawase (poetry contests), 98;

Chōmei's participation in, 66, 71 , 73-74, 76-78

utamakura (poetic place-names), 96 , 99 102, 109

Vimalakīrti, 10, 141-43, 149-50, 171

Vimalakirti Sutra, 7, 10, 139-43, 168, 170

Visuddhimagga, 116

vyavahāra (conventional language), 31

wagakusha, 4-5

waka, 7, 24, 52, 77, $110,114,122$, 137-38; and Buddhism, 35-37, 53 , 102; defense of, $36,42-43,45-49$; idealization of, 95-96; as kyögen kigo, 134-35; and love, 34, 45; and michi, 39-42, 53-54, 94, 102, 1046 ; as religious practice, $42-51$. 129, 136; sacrificing life for, 102-3 wakadokoro. See Bureau of Poetry Wakan rōeishu, 21, 163 wild words and fancy phrases. See kyögen kigo

Yamada Shōzen, 16-17, 21, 166-68, 170

yaminu, 166-67, 169

Yanase Kazuo, 70

Yorikiyo, 125-26

Yorimasa, 104, 106, 113

Yorizane, 102, 106

yoshinsō, 60, 160

Yoshishige Yasutane, 19-21, 82, 137$40,146-56,161$

$y \bar{u}$ (refinement), $117-19,123,126$

Yuan Chen, 14-15

yūgen, 96

Zenjaku, 79-80

zoku, 18, 108

Zoku honchō ōjōden, 50 



\section{ABOUT THE AUTHOR}

Rajyashree Pandey teaches Japanese language and literature in the Department of Asian Studies at La Trobe University in Melbourne, Australia. She has published articles on medieval Japanese literature in a number of journals, including Monumenta Nipponica and the Journal of the Royal Asiatic Society. She is currently writing a book on representations of women in setsuwa. 
